
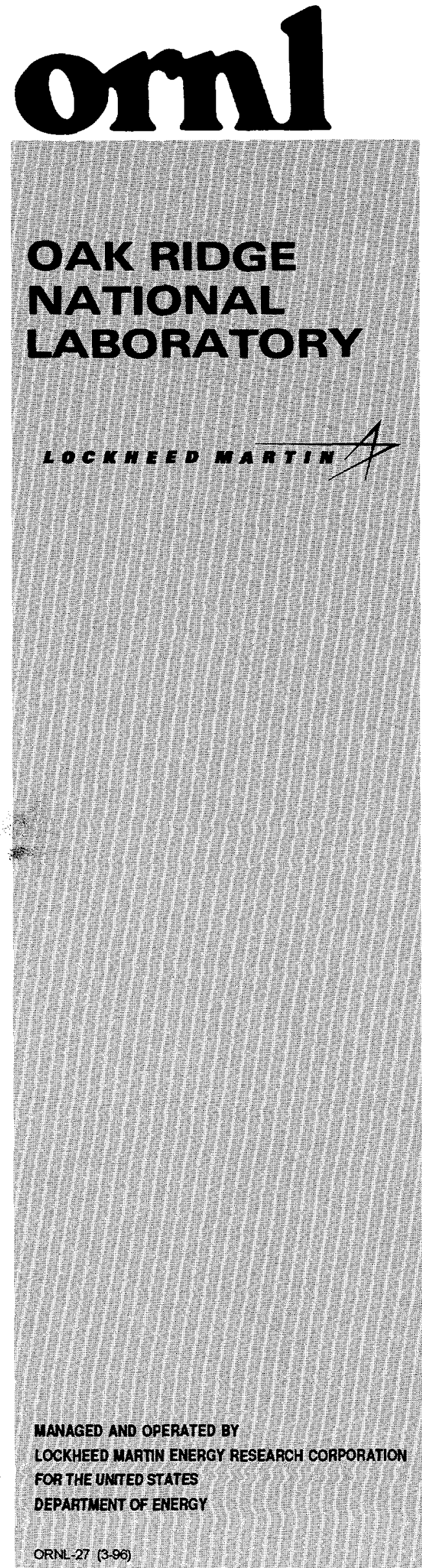

OSTI

Metals and Ceramics Division

CRADA Final Report

for CRADA Number ORNL 92-0123

\title{
DEVELOPMENT OF CLADDING MATERIALS FOR EVACUATED PANEL SUPERINSULATION
}

K. E. Wilkes and F. J. Weaver

Oak Ridge National Laboratory

G. M. Cumberbatch, B. Begnoche, V. Brodie, W. Lamb, R. Reitz, and P. Caldwell

E. I. DuPont de Nemours and Company

C. Meyer

VacuPanel, Inc.

Date Published - November 1999

\author{
Prepared by the \\ OAK RIDGE NATIONAL LABORATORY \\ Oak Ridge, Tennessee 37831 \\ managed by \\ LOCKHEED MARTIN ENERGY RESEARCH \\ CORPORATION \\ for the \\ U.S. DEPARTMENT OF ENERGY \\ under contract DE-AC05-96OR22464
}

\author{
APPROVED FOR PUBLIC RELEASE \\ DISTRIBUTION IS UNLIMITED
}


This report has been reproduced from the best available copy.

Reports are available to the public from the following source.

National Technical Information Service

5285 Port Royal Road

Springfield, VA 22161

Telephone 703-605-6000 (1-800-553-6847)

TDD 703-487-4639

Fax 703-605-6900

E-mail orders@ ntis.fedworld.gov

Web site http://www.ntis.gov/ordering.htm

Reports are available to U.S. Department of Energy (DOE) employees, DOE contractors, Energy Technology Data Exchange (ETDE) representatives, and International Nuclear Information System (INIS) representatives from the following source.

Office of Scientific and Technical Information

P.O. Box 62

Oak Ridge, TN 37831

Telephone 423-576-8401

Fax 423-576-5728

E-mail reports@adonis.osti.gov

Web site http://www.osti.gov/products/sources.html

Reports produced after January 1, 1996, are generally available via the DOE Information Bridge.

Web site http://www.doe.gov/bridge 


\section{DISCLAIMER}

This report was prepared as an account of work sponsored by an agency of the United States Government. Neither the United States Government nor any agency thereof, nor any of their employees, make any warranty, express or implied, or assumes any legal liability or responsibility for the accuracy, completeness, or usefulness of any information, apparatus, product, or process disclosed, or represents that its use would not infringe privately owned rights. Reference herein to any specific commercial product, process, or service by trade name, trademark, manufacturer, or otherwise does not necessarily constitute or imply its endorsement, recommendation, or favoring by the United States Government or any agency thereof. The views and opinions of authors expressed herein do not necessarily state or reflect those of the United States Government or any agency thereof. 


\section{DISCLAIMER}

Portions of this document may be illegible in electronic image products. Images are produced from the best available original document. 
Metals and Ceramics Division

CRADA Final Report

for CRADA Number ORNL 92-0123

\title{
DEVELOPMENT OF CLADDING MATERIALS \\ FOR EVACUATED PANEL SUPERINSULATION
}

K. E. Wilkes and F. J. Weaver

Oak Ridge National Laboratory

\author{
G. M. Cumberbatch, B. Begnoche, V. Brodie, W. Lamb, R. Reitz, and P. Caldwell \\ E. I. DuPont de Nemours and Company \\ C. Meyer \\ VacuPanel, Inc.
}

Date Published - November 1999

Prepared by the

OAK RIDGE NATIONAL LABORATORY

Oak Ridge, Tennessee 37831 managed by

LOCKHEED MARTIN ENERGY RESEARCH

CORPORATION

for the

U.S. DEPARTMENT OF ENERGY

under contract DE-AC05-96OR22464 



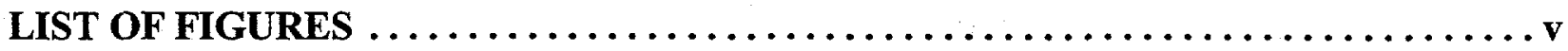

LIST OF TABLES $\ldots \ldots \ldots \ldots \ldots \ldots \ldots \ldots \ldots \ldots \ldots \ldots \ldots \ldots \ldots \ldots \ldots \ldots \ldots \ldots \ldots \ldots$

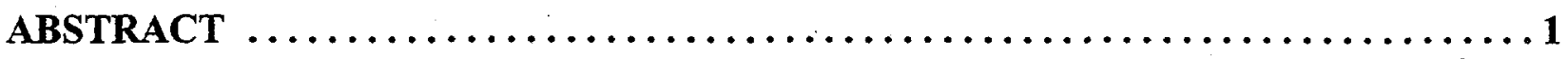

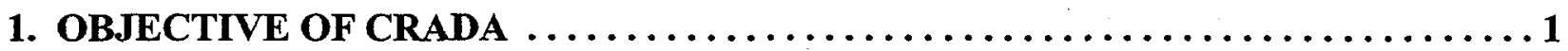

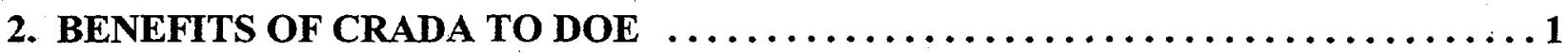

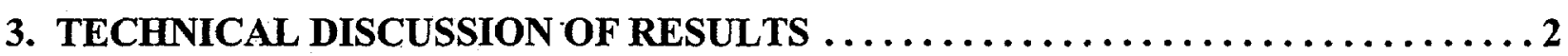

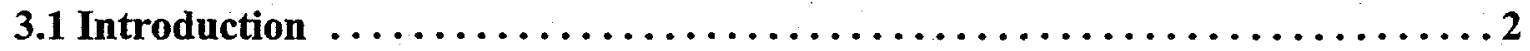

3.2 Development of Vacuum Cladding Films $\ldots \ldots \ldots \ldots \ldots \ldots \ldots \ldots \ldots \ldots \ldots$

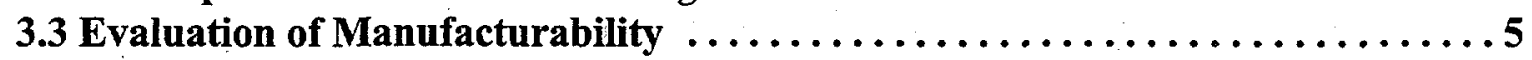

3.4 Evaluation of Gas Permeance of Films $\ldots \ldots \ldots \ldots \ldots \ldots \ldots \ldots \ldots \ldots, \ldots \ldots \ldots$

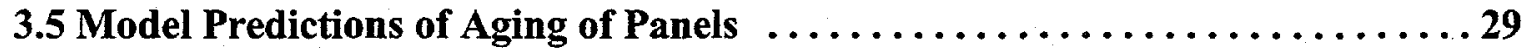

3.6 Thermal Resistivity Measurements on Vacuum Insulation Panels ......... 33

3.7 Effect of Edge Conduction on Performance of Vacuum Insulation Panels .... 38

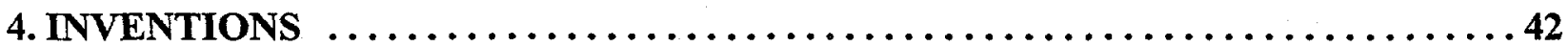

5. COMMERCIALIZATION POSSIBILITIES $\ldots \ldots \ldots \ldots \ldots \ldots \ldots \ldots \ldots \ldots, 42$

6. PLANS FOR FUTURE COLLABORATIONS $\ldots \ldots \ldots \ldots \ldots \ldots \ldots \ldots \ldots \ldots \ldots$

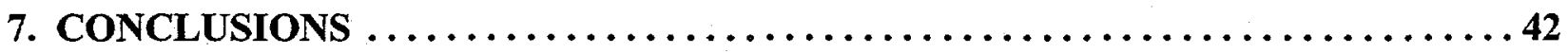

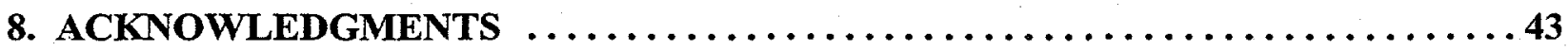

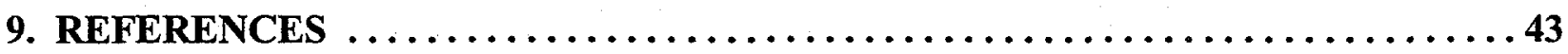

Appendix A 


\section{LIST OF FIGURES}

1. Effect of Pressure on Thermal Resistivity of Evacuated Panel Superinsulation with Foam

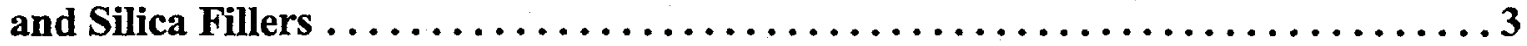

2. Data for Aging in Air of Panels with Vecat Cladding $\ldots \ldots \ldots \ldots \ldots \ldots \ldots \ldots \ldots \ldots \ldots$

3. Data for Aging in Helium of Panels with Vecat Cladding $\ldots \ldots \ldots \ldots \ldots \ldots \ldots \ldots \ldots$

4. Data for Analysis of Void Volume in Tyvek Film for Vecat-Clad Panels Aged in Helium

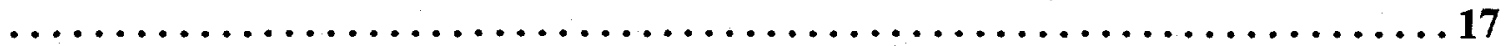

5. Data for Analysis of Void Volume in Tyvek Film for Vecat-Clad Panels Aged in Air 18

6. Effect of Cladding Permeance on Calculated Air Pressure Rise in One-Inch-Thick Evacuated Panel Superinsulation with $90 \%$ Void Volume ..............30

7. Effect of Cladding Permeance on Calculated Lifetime Thermal Resistivity of One-InchThick Silica-Filled Evacuated Panel Superinsulation with 90\% Void Volume ....31

8. Effect of Cladding Permeance on Calculated Lifetime Thermal Resistivity of One-InchThick Silica-Filled Evacuated Panel Superinsulation with $90 \%$ Void Volume ... 32

9. Measured Thermal Resistivity of Vacuum Insulation Panels . . . . . . . . . . . 35

10. Calculated Pressure Rise in Vacuum Insulation Panels ................... 36

11. Calculated Effect of Edge Heat Conduction on Thermal Performance of Vacuum Insulation Panels .41 


\section{LIST OF TABLES}

1. Typical Properties of Mylar 200 RBSL 300 Vacuum Insulation Panel Cladding Film . 6

2. Regression Parameters for Pressure-Time Data for Panels Aged in Air . . . . . . . . 14

3. Regression Parameters for Pressure-Time Data for Panels Aged in Helium . . . . . 15

4. Tyvek Void Volumes for Vecat-Clad Test Panels Aged in Air and Helium . . . . . . 19

5. Permeance of Vecat-Clad Panels Aged in Helium . . . . . . . . . . . . . 21

6. Permeance of Vecat-Clad Panels Aged in Air $\ldots \ldots \ldots \ldots \ldots \ldots \ldots \ldots \ldots \ldots \ldots \ldots$

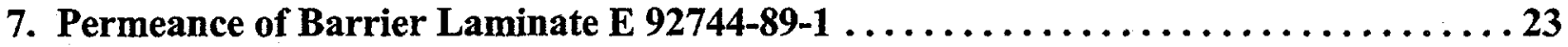

8. Permeance of Barrier Laminate E 92744-89-2 with Surlyn Layer . . . . . . . . . . . 23

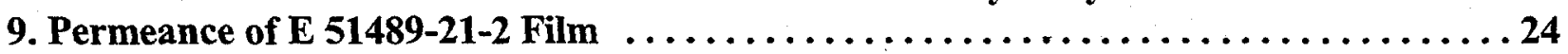

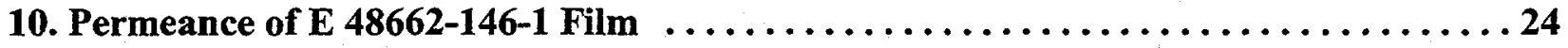

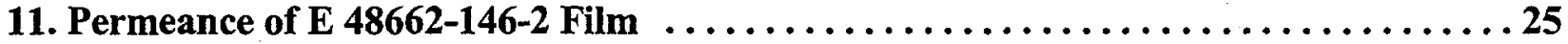

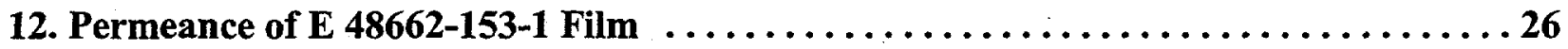

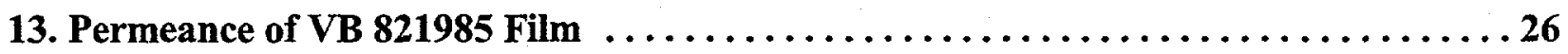

14. Comparison of Permeances of Various Claddings $\ldots \ldots \ldots \ldots \ldots \ldots \ldots \ldots \ldots$

15. Comparison of Air Permeance with Oxygen Transmission Rate (OTR) $\ldots . \ldots \ldots 28$

16. Results of Thermal Resistivity Measurements on Vacuum Insulation Panels . . . . . 34 


\title{
DEVELOPMENT OF CLADDING MATERIALS FOR EVACUATED PANEL SUPERINSULATION
}

\author{
K. E. Wilkes, F. J. Weaver, G. M. Cumberbatch, B. Begnoche, \\ V. Brodie, W. Lamb, R. Reitz, P. Caldwell, and C. Meyer ${ }^{1}$
}

\begin{abstract}
This Cooperative Research and Development Agreement (CRADA) was among E. I. DuPont de Nemours and Company, VacuPanel, Inc., and Lockheed Martin Energy Research Corp. Evacuated panel superinsulations have thermal resistivities (R) substantially above that of conventional existing insulation without the environmental problems of some insulations such as foam insulations blown with chlorofluorocarbons (CFCs) or hydrochlorofluorocarbons (HCFCs). For example, the $\mathrm{R}$ of an evacuated panel superinsulation is about seven times that of fiberglass insulation and about 2.5 times that of HCFC-blown foams. Consequentially, development of evacuated panel superinsulations could enable their use in many energy conservation applications as well as reducing the use of environmentally unacceptable insulation. One of the most promising applications of evacuated panel superinsulations is in home refrigerators/freezers $(\mathrm{R} / \mathrm{Fs})$, where estimates predict that about $0.6 \times 10^{15} \mathrm{Btu}$ ( 0.6 quads, which is $1 \%$ of the energy used in the United States) could be saved if evacuated panel superinsulations replaced CFCblown foam used to insulate R/Fs. A major accomplishment needed for development of evacuated panel superinsulations is the identification of new, low-permeability cladding materials to contain the vacuums in evacuated panels, with the cost versus performance of the cladding yielding the optimum cladding for this application.
\end{abstract}

\section{OBJECTIVE OF CRADA}

The objective of the CRADA was to identify new, low-permeability cladding materials for evacuated panel superinsulations, to determine their performance, and to optimize their cost versus performance.

\section{BENEFITS OF CRADA TO DOE}

ORNL has been performing extensive R\&D on the development of evacuated panel superinsulation technology for the DOE. The information developed in this CRADA had a synergistic effect on the superinsulation development program conducted by ORNL for DOE. This effort resulted in improved cladding materials and an improved understanding of the relationship between cladding permeabilities and performance of superinsulations.

${ }^{1}$ K. E. Wilkes and F. J. Weaver, Metals \& Ceramics Division, Oak Ridge National Laboratory; G. M. Cumberbatch, B. Begnoche, V. Brodie, W. Lamb, R. Reitz, P. Caldwell, E. I. DuPont de Nemours and Company; C. Meyer, VacuPanel, Inc. 


\section{TECHNICAL DISCUSSION OF RESULTS}

\subsection{Introduction}

Heat transfer through evacuated panel superinsulations occurs through the modes of conduction through the solid filler, conduction through the residual interstitial gas, and radiation through the absorbing, scattering, and emitting filler medium.[1] The other basic mode of heat transfer, natural convection, is usually considered to be negligible for most types of insulation. For the fillers used in evacuated panels, the pore sizes are so small that convection may be safely ignored.

If the vacuum were perfect, only conduction through the solid particles and radiation would be present and there would be no gaseous conduction. Conduction through any residual gas depends upon the size of the mean free path of the gas molecules relative to the pore size. Gaseous conduction is small when the mean free path of the gas molecules is large compared with the pore size, and is large when the mean free path is small compared with the pore size. In addition, the mean free path of the gas varies inversely with the gas pressure. The net result is that the thermal resistivity of an evacuated panel varies with gas pressure as shown in Figure 1 , where data are shown for two types of fillers - precipitated silica powder and extruded polystyrene foam. The curves for the two fillers have the same general shape, but the resistivity for the foam filler decreases with increasing pressure more quickly than for the silica powder. This is because the size of the foam cells is larger than the pore size in the powder. Data for the silica powder were measured at ORNL, while data for the foam filler were taken from Dow Chemical advertising material.

When evacuated panel superinsulations are manufactured, the gas pressure will be very low, and the resistivity will be high. With time, air will permeate through the cladding of the panel, increasing the gas pressure and decreasing the thermal resistivity. Thus the key to maintaining a high thermal resistivity is to minimize the amount of gas that can permeate through the cladding. One solution is to use a metal cladding, such as stainless steel. While this would be essentially impermeable, it has the drawback that the high thermal conductivity of the stainless steel creates a thermal short circuit around the high thermal resistivity evacuated filler 


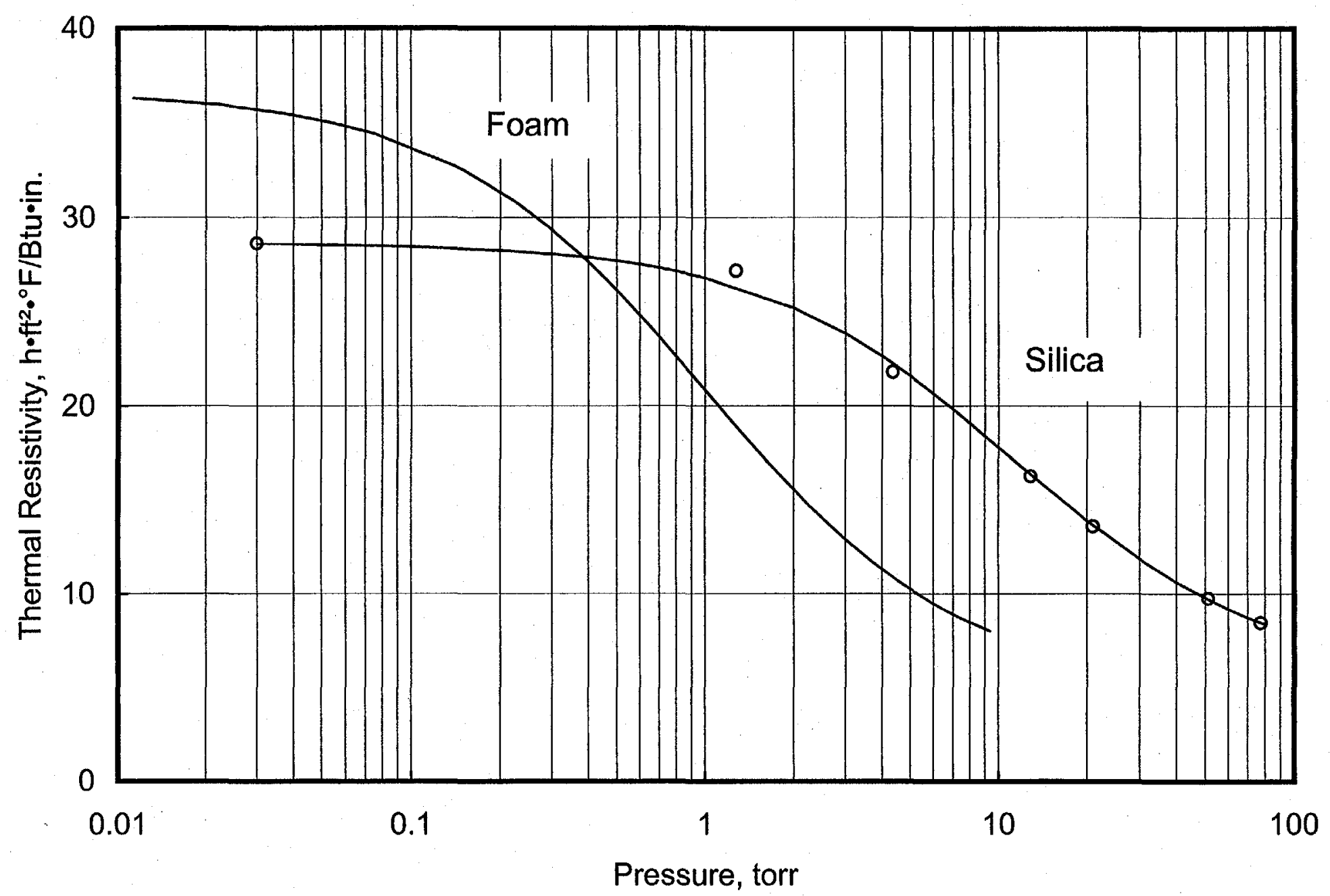

$\omega$

Figure 1. Effect of Pressure on Thermal Resistivity of Evacuated Panel Superinsulation with Foam and Silica Fillers 
and can greatly reduce the effective resistivity of an evacuated panel. Claddings based on polymers do not create such a thermal short circuit, but allow permeation of gases.

The approach taken in this project was to develop and evaluate polymer-based claddings that contained a thin layer of metal (aluminum). The claddings were designed so that the metal layer would present a large barrier to permeation of gases, but would be thin enough that it would not create a thermal short circuit. DuPont developed a series of films for use as claddings, and VacuPanel evaluated the ability to use the films in manufacturing vacuum insulation panels. ORNL measured the permeance of the films to air, estimated the aging of vacuum insulation panels due to permeation of air, measured the thermal resistivity of vacuum insulation panels over time, and evaluated the effects of edge heat conduction on overall panel thermal performance.

\subsection{Development of Vacuum Cladding Films}

New films for use as vacuum claddings were developed by DuPont. The development was based on several performance factors. First, the films must have low permeation rates for atmospheric gases, including water vapor. Second, the films must have low thermal conductivity to minimize effects of heat conduction around the edges of vacuum insulation panels. Third, the films must be capable of being easily sealed, and the seal must have high integrity with high seal strength, no leakage, and no degradation over time. Finally, the film must be flexible, yet durable, with high resistance to puncture, abrasion, and stress cracks.

Since no one material meets all of the above performance factors, the films were developed as composite structures by laminating several layers with each layer contributing to one or more of the requirements. In general, the layers fell into three categories: structural films, sealant films, and gas barrier films. Materials that might be used for structural films included biaxially oriented polyester, cast or biaxially oriented polyamide, polycarbonate, and biaxially oriented polypropylene. Because of DuPont's long experience with Mylar films, which are biaxially oriented polyester, this material was chosen for use as the structural film. Metal foils were not considered as candidates for the structural layer because of their high thermal conductivity. Sealant materials that were considered included polyester, polyvinylidene chloride 
(PVDC or Saran), polyethylene, ionomers, and acid copolymers. Gas barrier materials that were considered included glass or $\mathrm{SiO}_{\mathrm{x}}$, amorphous nylon, polyvinylidene chloride (PVDC or Saran), vapor deposited aluminum, polyvinyl alcohol, and ethylene vinyl alcohol. Aluminum foil was not considered for a gas barrier because of its high heat conduction.

Several generations of films were developed. The starting point was films that were already commercialized, which consisted primarily of biaxially oriented polyester films with vacuum aluminized coatings. They were produced with and without a sealant layer made of an ionomer (trademarked Surlyn by DuPont), and were labeled E 92744-89-1 (without Surlyn layer) and E 92744-89-2 (with Surlyn layer). Next, three experimental films were developed for evaluation, labeled E 51489-21-2, E 48662-146-1, and E 48662-146-2. The next generation of films carried the labels of E 48662-153-1 and VB 821985. These latter two films were found to be suitable for initial introduction to the marketplace, with the commercial material being labeled Mylar 200 RSBL 300 . Both the experimental and commercial films were based on biaxially oriented polyester films to provide the structural element, vacuum deposited aluminum layers to provide gas barriers, and other polymer layers to provide additional gas barriers and a sealant layer. Typical properties of the commercial film are given in Table 1.

\subsection{Evaluation of Manufacturability}

VacuPanel used the films developed by DuPont to manufacture several hundred vacuum insulation panels. In particular, VacuPanel has made panels from the following experimental films: E 51489-21-2, E 48662-146-1, E 48662-146-2, and E 48662-153-1. All panels were made to an approximate size of $10^{\prime \prime} \times 12^{\prime \prime} \times 1 "$.

All of the sample panels were made using Dow Chemical's Instill@ open-cell rigid polystyrene foam as a filler, Multisorb 5 gram calcium oxide desiccant packets, and VacuPanel's patented direct evacuation process. In this process, film bags were made with a spout design similar to that of a helium balloon. Desiccant packets were inserted into routed slots in the foam. The foam panels were inserted in the film bag and the tail section was sealed, resulting in a bagged panel in which only the spout was open. The open spout was slid onto a direct evacuation nozzle attached to a controlled series of valves, a pressure gauge, and an evacuation 
Table 1. Typical Properties of Mylar 200 RBSL 300 Vacuum Insulation Panel Cladding Film

\begin{tabular}{|l|l|l|}
\hline Property & Value & ASTM Test \\
\hline Yield & $8700 \mathrm{in.}{ }^{2} / \mathrm{lb}$ & - \\
\hline Unit Weight & $49.6 \mathrm{lb} / \mathrm{ream}$ & E $252\left(0.5 \mathrm{~m}^{2}\right)$ \\
\hline Thickness & $0.0023 \mathrm{in}$. & D 374 \\
\hline Ultimate Tensile Strength & $\begin{array}{l}24,000 \mathrm{lb} / \mathrm{in} .^{2} \text { (machine direction) } \\
27,000 \mathrm{lb} / \mathrm{in}^{2} \text { (transverse direction) }\end{array}$ & D 882 \\
\hline Elongation at Break & $\begin{array}{l}135 \% \text { (machine direction) } \\
95 \%(\text { transverse direction) }\end{array}$ & D 882 \\
\hline Modulus & $435,000 \mathrm{lb} /$ in. $^{2}$ & D 882 \\
\hline Graves Tear & $6.5 \mathrm{lb}$ & D 1004 \\
\hline Water Vapor Transmission Rate & $\begin{array}{l}0.0003 \mathrm{~g} / 100 \text { in. } .^{2} \text { day } \\
\text { at } 73^{\circ} \mathrm{F} \text { and } 50 \% \text { relative humidity }\end{array}$ & F 1249 \\
\hline Oxygen Transmission Rate & $\begin{array}{l}0.00004 \mathrm{~cm}^{3} / 100 \text { in. } .^{2} \text { day } \\
\text { at } 73^{\circ} \mathrm{F} \text { and } 50 \% \text { relative humidity }\end{array}$ & D 3985 \\
\hline
\end{tabular}

pump. The panel was evacuated to a measured pressure of about 0.1 torr. The measurement was done by measuring the pressure rise in the foam with the pump valve closed using the in-line pressure gauge. Once the desired vacuum pressure level was achieved, the film spout was heat sealed and the panel was removed. Completed panels were then tested to determine their thermal conductivity values.

In assessing the ease of use of these films in the panel fabrication process, particularly important are the following: ease of handling of film in bag making, ease and quality of seal, strength of seal, and abrasion resistance or toughness of film, so that it is not easily damaged during fabrication, shipping, and installation. VacuPanel's observations of these films are general in nature. There were no major differences observed from film to film. There were some obvious differences noted when comparing these to other barrier film types, such as film laminates using a foil layer or completely plastic film laminates containing no foil or metallizing. 
These observations follow:

- Each of the DuPont films used tended to be easy to handle. They do not curl, but rather lie flat. The slick surfaces are advantageous in the flow of the product during the bag making process, but mean that the bags cannot be stacked;

- The thin seal layers require greater care in sealing to insure effective seals. These seals tend to have less shear strength than more standard polyethylene seal layers. However, with care, very good seals are possible;

- For three-dimensional shapes, these films are easier to use and tend to be less prone to cracking and seal leaks;

- These films were not as abrasion resistant or tough as other types of films and therefore required more care during fabrication, shipping, and installation. DuPont has, subsequent to these tests, enhanced the thickness of one of the polyester layers in their barrier films. This seems to result in a more durable product;

- In making bags which include a film fold in place of one side seal, the seal of the fold corner is not secure and requires an additional, angle seal to insure seal quality.

In general, VacuPanel has found the DuPont films tested herein to be relatively easy to use and to adapt to production volumes. Several of the films have required increased evacuation times to reach evacuation specifications. This can be overcome by a pre-heating cycle, but does need to be considered in production planning. DuPont is aware of this outgassing characteristic and has taken measures to improve it. 


\subsection{Evaluation of Gas Permeance of Films}

\subsubsection{Model for Aging of Evacuated Panel Superinsulations}

This section describes a model for calculating the pressure rise in an evacuated panel as gas permeates through the cladding. The starting point is the law of conservation of mass which equates the mass flow of gas into a panel to the increase in internal mass of the gas. The mass flow rate of gas permeating through the surface of a panel is given by

$$
\frac{\mathrm{dm}}{\mathrm{dt}}=\rho_{\mathrm{o}} \mathrm{KA}\left(\mathrm{P}_{\mathrm{a}}-\mathrm{P}\right)
$$

where $\mathrm{dm} / \mathrm{dt}=$ mass flow rate of permeating gas

$\rho_{0}=$ density of gas at standard temperature and pressure $\left(0^{\circ} \mathrm{C}\right.$ and 760 torr $)$

$\mathrm{K}=$ permeance of surface

$A=$ area of surface

$\mathrm{P}_{\mathrm{a}}=$ pressure of external gas

$\mathrm{P}=$ pressure of panel interior

For this report, the units for $\mathrm{K}$ are taken to be $\mathrm{cc}(\mathrm{STP}) / 100 \mathrm{in} .^{2} \cdot \mathrm{atm} \bullet$ day, with the above quantities having the appropriate (admittedly mixed) units.

The increase in internal mass of gas is given by

$$
\frac{\mathrm{dm}}{\mathrm{dt}}=\mathrm{V} \frac{\mathrm{d} \rho}{\mathrm{dt}}
$$

where $\mathrm{V}=$ internal volume of panel

$\rho=$ density of gas inside panel

Equating Equations 1 and 2, and applying the ideal gas law gives

$$
\rho_{\mathrm{o}} \mathrm{KA}\left(\mathrm{P}_{\mathrm{a}}-\mathrm{P}\right)=\frac{\mathrm{VM}}{\mathrm{RT}} \frac{\mathrm{dP}}{\mathrm{dt}}
$$

where $\mathrm{M}=$ molecular weight of gas

$\mathrm{R}=$ ideal gas constant 
$\mathrm{T}=$ absolute temperature

With constant $P_{a}, T$, and $V$, Equation 3 may be integrated to give the following expression for the internal pressure versus time

$$
P=P_{a}+\left(P_{0}-P_{a}\right) \exp \left[-K \frac{A}{V} \frac{\rho_{0} R T}{M} t\right]
$$

where $P_{0}=$ initial internal pressure of gas

The quantity $\mathrm{M} / \rho_{\mathrm{o}}$ is independent of the gas and is equal to $22,415 \mathrm{~cm}^{3} / \mathrm{mole}$. Also, since the gas constant equals $82.057 \mathrm{~atm} \cdot \mathrm{cm}^{3} / \mathrm{mole} \cdot \mathrm{K}$, the quantity $\rho_{0} \mathrm{RT} / \mathrm{M}$ equals $1.118 \mathrm{~atm}$ for a temperature of $90^{\circ} \mathrm{F}$.[2] The above equations are all based on the partial pressure of one gas. If more than one gas is involved, then Equation 4 would be used to determine the partial pressure of each gas, and these would be summed to give the total pressure.

\subsubsection{Method for Measuring Permeance}

The model given in Section 3.4.1 has been used to develop a patented method for measuring the effective permeance of films used as cladding materials.[3] (This patent did not result from this CRADA.) The method relies upon the observation that the pressure rise can be accelerated if the quantity $\mathrm{A} / \mathrm{V}$ is made large. This was accomplished by using test panels with very small internal gas volumes compared with that in evacuated panel superinsulations. Instead of a powder or foam filler, the test panels contained a filler made of a solid metal plate or a perforated metal plate with a small volume of perforations.

Flat aluminum plates with rounded edges were used as the filler for the test panels. Nominal lateral dimensions were about 9 inches by 9 inches with a thickness of 0.26 inches. With rounding of the corners, the projected surface area was 75 square inches. In addition to solid metal plates, plates of similar size were made with a grid of 1049 holes to give void volumes of about $2.5 \%$ and $5 \%$ of the plate's volume. The density of each plate before drilling of the holes was measured by immersion in water and application of Archimedes' principle. The void volumes associated with the drilled holes were determined from the measured density and the weight loss upon drilling. 
The plates were cleaned and then baked in an oven at $250^{\circ} \mathrm{F}$ for one hour. Sheets of Tyvek film were also baked for one hour at $250^{\circ} \mathrm{F}$. After baking, the plates were encapsulated in the Tyvek film, the heat sealed edges of which were trimmed to within about $1 / 8$ to $1 / 4$ inch of the metal plate. The Tyvek-encapsulated plates were then placed into pouches made of the test film. These assemblies were placed in a vacuum packer, and were pumped to a pressure of 0.5 torr, after which the open ends of the pouches were heat-sealed under vacuum. This sequence simulated the construction of a powder-filled evacuated superinsulation, with the powder being replaced with the metal plate.

The panels were aged in constant pressure, constant temperature aging chambers. The chambers were constructed from 24 inch diameter schedule 10 Type 304 stainless steel pipe. The chambers were 24 inches long and were fitted with doors containing rubber O-rings. The test panels were placed on internal expanded metal shelves. The chambers were fitted with a vacuum system and valve system to allow flushing and filling with gases from cylinders. The pressures inside the chambers were maintained at 785 torr (slightly above normal atmospheric pressure) and the pressures were measured with capacitance manometers. The chambers were fitted with copper coils connected to constant temperature baths to maintain the chambers at a constant temperature of $90^{\circ} \mathrm{F}$.

After fabrication of the test panels, their internal pressures were measured using a patented hand-held vacuum gauge that was developed at ORNL.[4] (Again, this patent was not a part of the present CRADA.) The panels were then placed in the aging chambers and were removed periodically for measurements of internal pressure as the gas in the chambers permeated into the panels. Since the panels were aged at $90^{\circ} \mathrm{F}$ and the pressure measurements were performed at the laboratory temperature of about $70^{\circ} \mathrm{F}$, the measured pressures were corrected to $90^{\circ} \mathrm{F}$ using the ideal gas law. (Note, this is a refinement in data analysis that was not included in preliminary communications of results.)

Figures 2 and 3 show examples of pressure-time data. These data were taken on a set of panels made with an all-polymer commercial film (Vecat). One panel contained a solid metal plate, while the other two panels contained perforated metal plates with plate porosities of about 


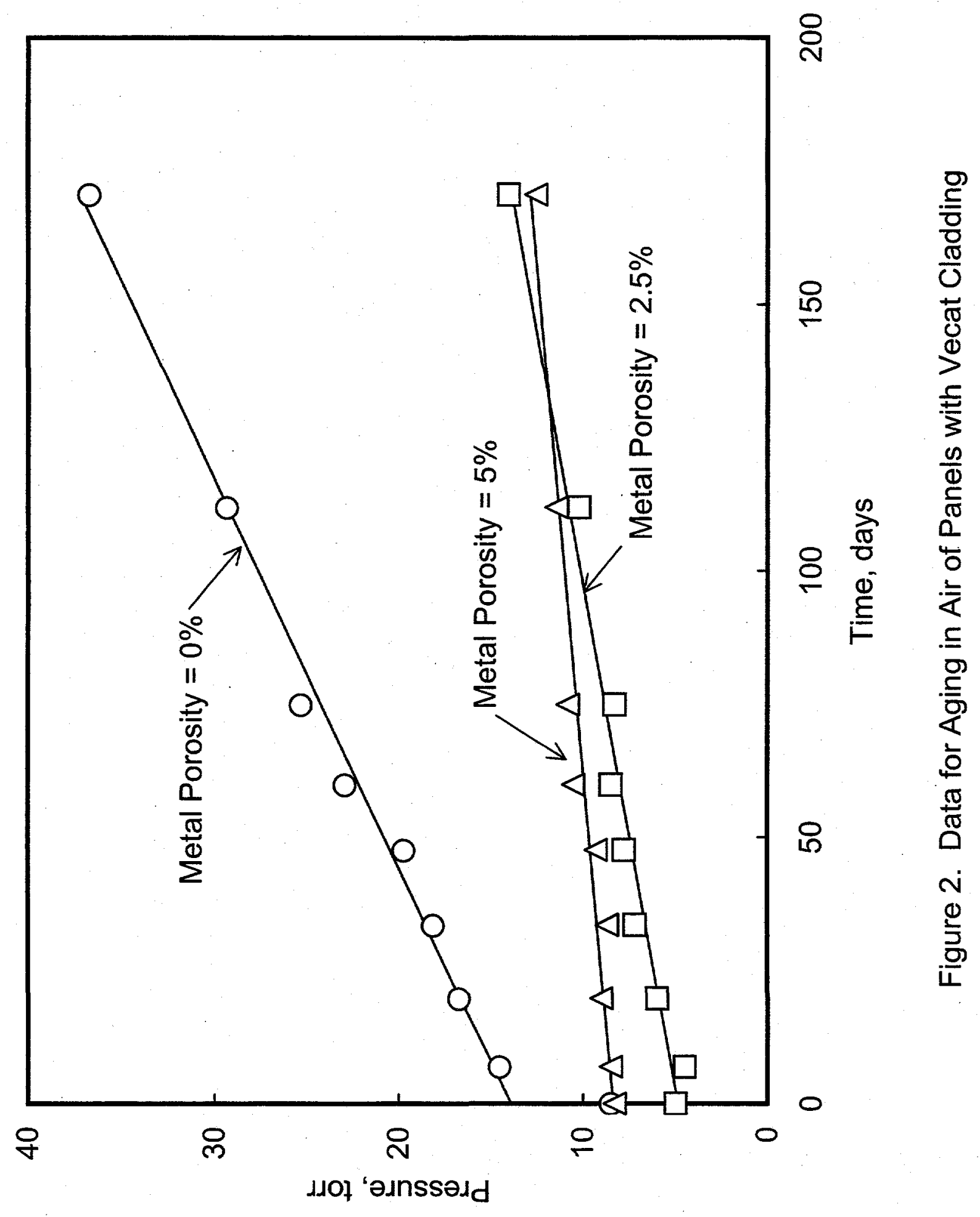




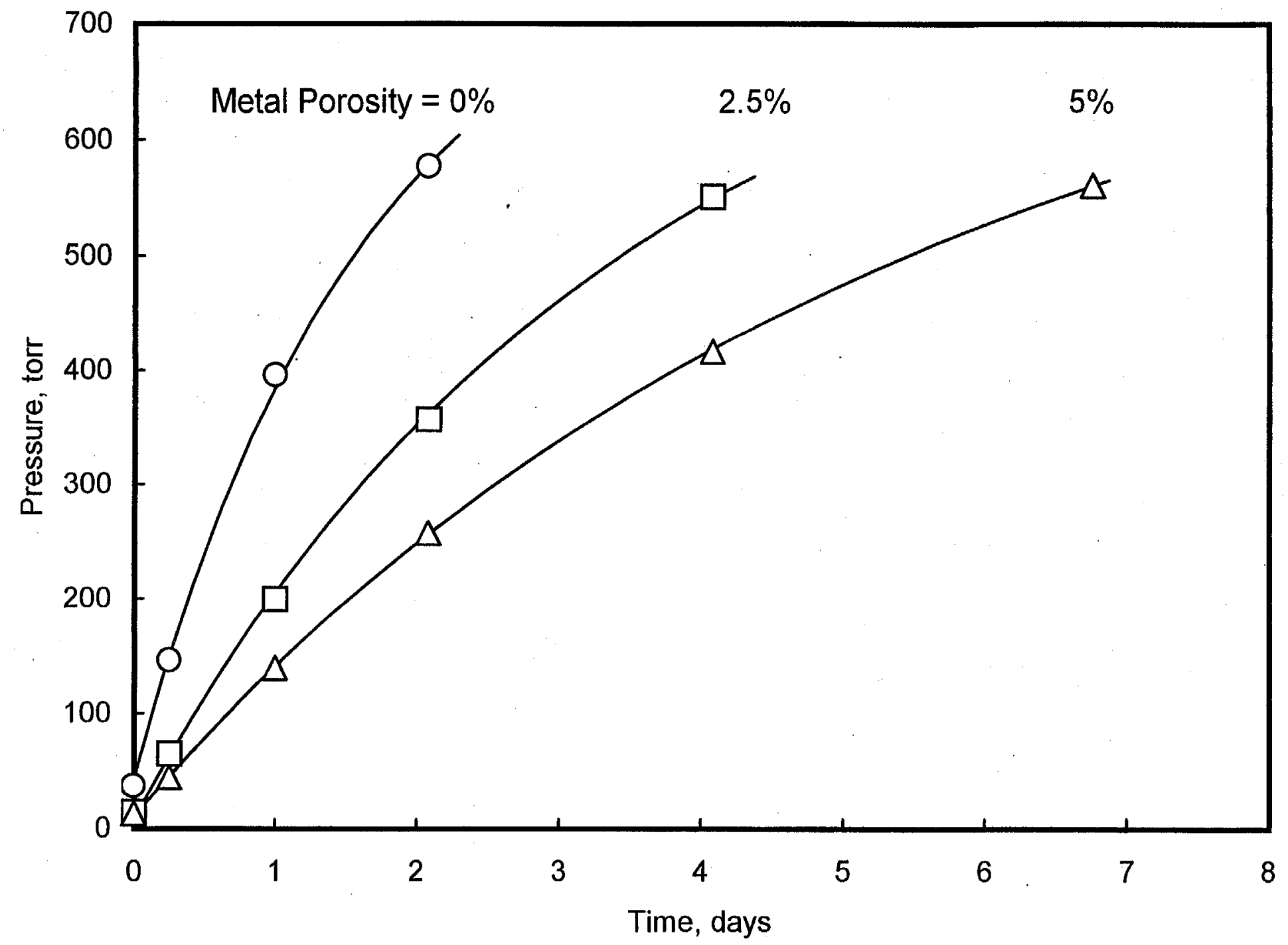

Figure 3. Data for Aging in Helium of Panels with Vecat Cladding 
$2.5 \%$ and $5 \%$. Figure 2 shows data obtained as the panels were aged in dry air at $90^{\circ} \mathrm{F}$ and 785 torr. While the panels were pumped down to 0.5 torr during fabrication, the initial pressure was . higher, being in the range of about 5 to 10 torr. This is attributed to the fact that the cladding film was not forced to conform to the Tyvek-covered metal plate during pumpdown and sealing. The result was some amount of internal volume between the cladding and the filler after sealing. Upon exposing the evacuated panels to atmospheric pressure, the cladding was forced to conform with the filler and the residual gas was compressed to a higher pressure. After aging in air for about six months, the panels were removed from the chamber containing dry air and were placed in a similar chamber containing helium. Data obtained in helium over a period of two to seven days are shown in Figure 3. The data corresponding to these figures are included in Appendix A, where the panels are labeled V-II-1, V-I-2, and V-I-3. These data are used to give an example of the method for extracting permeance values from the pressure-time data.

With aging in air, the pressure rises were small and the pressure increased linearly with time. This is in conformance with Equation 4, where retention of the first two terms of a Taylor series expansion of the exponential function gives

$$
P=P_{0}+\left(P_{a}-P_{0}\right)\left[K \frac{A}{V} \frac{\rho_{0} R T}{M} t\right]
$$

A linear regression of the data to the form

$$
P=a+b t
$$

allows estimation of $P_{0}=a$, and

$$
K=\frac{b}{P_{a}-a} \frac{V}{A} \frac{M}{\rho_{0} R T}
$$

In some cases, the first one or two data points did not fit with the trend of the later data and were not used in the regressions. This is the case for Panels V-II-1 and V-II-2. Regression results for these three panels in air are given in Table 2. The coefficient of determination $\left(\mathrm{r}^{2}\right)$ for panel V-II1 shows that a linear equation gives a very good fit to the data. For the other two panels, where 
the pressure rises were much smaller, the $r^{2}$ values are correspondingly lower.

Table 2. Regression Parameters for Pressure-Time Data for Panels Aged in Air

\begin{tabular}{|c|c|c|c|}
\hline Panel & $\mathrm{a}$ & $\mathrm{b}$ & $\mathrm{r}^{2}$ \\
\hline V-II-1 & 14.45 & $5.902 \times 10^{-3}$ & 0.9920 \\
\hline V-II-2 & 5.053 & $2.266 \times 10^{-3}$ & 0.9674 \\
\hline V-II-3 & 8.687 & $1.124 \times 10^{-3}$ & 0.9378 \\
\hline
\end{tabular}

The pressure rises in helium were much faster and were nonlinear at longer times as they approached the pressure maintained within the chamber. The pressure versus time in helium is given by a modification of Equation 4,

$$
P=P_{b}+P_{a}\left[1-\exp \left(-K \frac{A}{V} \frac{\rho_{0} R T}{M} t\right)\right]
$$

where $\mathrm{P}_{b}$ is the background pressure due to the air inside the panels after aging for six months in air. Also, the initial pressure of helium inside the panels was zero. Equation 8 may be rearranged as

$$
\ln \left[\frac{\mathrm{P}-\mathrm{P}_{\mathrm{b}}-\mathrm{P}_{\mathrm{a}}}{-\mathrm{P}_{\mathrm{a}}}\right]=-\mathrm{K} \frac{\mathrm{A}}{\mathrm{V}} \frac{\rho_{\mathrm{o}} \mathrm{RT}}{\mathrm{M}} \mathrm{t}
$$

A linear regression of the data to the form

$$
\ln \left[\frac{\mathrm{P}-\mathrm{P}_{\mathrm{b}}-\mathrm{P}_{\mathrm{a}}}{-\mathrm{P}_{\mathrm{a}}}\right]=\mathrm{a}-\mathrm{bt}
$$

should yield a value of "a" that is very close to zero, and the permeance is given by 


$$
K=b \frac{V}{A} \frac{M}{\rho_{0} R T}
$$

Table 3 gives the regression results for these three panels in helium. Here the $\mathrm{r}^{2}$ values are all very close to unity, indicating that the data conform well to Equation 8.

Table 3. Regression Parameters for Pressure-Time Data for Panels Aged in Helium

\begin{tabular}{|c|c|c|c|}
\hline Panel & $\mathrm{a}$ & $\mathrm{b}$ & $\mathrm{r}^{2}$ \\
\hline V-II-1 & $-1.041 \times 10^{-2}$ & $2.514 \times 10^{-2}$ & 0.9987 \\
\hline V-II-2 & $1.142 \times 10^{-2}$ & $1.266 \times 10^{-2}$ & 0.9993 \\
\hline V-II-3 & $5.857 \times 10^{-3}$ & $7.967 \times 10^{-3}$ & 0.9998 \\
\hline
\end{tabular}

From the regressions of pressure versus time, the permeance can be calculated from Equations 7 and 11, provided the surface area, $\mathrm{A}$, and the internal volume, $\mathrm{V}$, are known. The internal volume includes the known volume of the holes drilled in the metal plate as well as some additional volume associated with the porosity of the Tyvek film.

The data obtained on the three panels with different amounts of volume due to holes in the metal filler were used to estimate the volume within the Tyvek film. Rearranging Equations 7 (for aging in air) and 11 (for aging in helium) give

$$
\frac{A\left(P_{a}-a\right)}{b}=\frac{1}{K} \frac{M}{\rho_{o} R T}\left(V_{\text {holes }}+V_{\text {Tyvek }}\right)
$$

and

$$
\frac{\mathrm{A}}{\mathrm{b}}=\frac{1}{\mathrm{~K}} \frac{\mathrm{M}}{\rho_{\mathrm{o}} \mathrm{RT}}\left(\mathrm{V}_{\text {holes }}+\mathrm{V}_{\text {Tyvek }}\right)
$$

where $V_{\text {holes }}$ is the volume of the holes in the metal plate and $V_{\text {Tyvek }}$ is the volume due to the porosity of the Tyvek film. Assuming the permeances and the volume due to the Tyvek to be the same for each of the three panels, plots of the left hand side of Equations 12 and 13 versus $V_{\text {holes }}$ 
should be straight lines. If the total internal volume were equal to the known volume of the holes, these plots should go through the origin. The amount by which the $\mathrm{x}$-intercept is shifted to the left from the origin will be equal to $\mathrm{V}_{\text {Tyvek }}$. Figure 4 shows the plot for aging in helium for the data of this example. The three points are fitted very well by a straight line, and yield $\mathrm{V}_{\text {Tyvek }}=6.8$ $\mathrm{cm}^{3}$. The plot for air, given in Figure 5, is based only on the two points for the smaller values of $\mathrm{V}_{\text {hoies; }}$, the third point was dropped from the plot because the pressure rise was so small that the coefficient $b$ was not very well determined. The plot for air gives $V_{\text {Tyvek }}=4.7 \mathrm{~cm}^{3}$. With these estimates for $V_{\text {Tyvek }}$, Equations 7 and 11 were used to calculate permeances. Results of these calculations are given in the next section, along with results for several other test panels made with Vecat.

Values of 5 to $7 \mathrm{~cm}^{3}$ appear to be reasonable for $V_{\text {Tyvek- }}$. The Tyvek layer was about 0.003 inches thick and had a total area of slightly more than $160 \mathrm{in}^{2}$, giving a total volume of $7.8 \mathrm{~cm}^{3}$. A pore volume of $6 \mathrm{~cm}^{3}$ corresponds to a porosity of about $75 \%$, which is a reasonable value for this film. Since there is some uncertainty in the value for $V_{\text {Tyvek }}$, it would be desirable to make $\mathrm{V}_{\text {Tyvek }}$ much smaller than $\mathrm{V}_{\text {holes. }}$. The Tyvek layer is needed to allow for free lateral movement of gases within the panels. $V_{\text {holes }}$ could be made much larger, but a much longer time period would be needed to obtain pressure-time curves and this would defeat the strategy of accelerating the test. Consequently, the present arrangement was accepted as a compromise.

\subsubsection{Permeance Data for Vecat Films}

Permeance measurements were performed on four sets of test panels made with Vecat cladding. The first two sets of panels were made with a Vecat pouch that was 10 inches wide and about 15 inches long, with the Tyvek-clad metal plate being at one end. The objective of this configuration was to provide a large area for permeation of the gases and hence to accelerate the test. The third and fourth sets of panels were made with a nominally 10 inch square area between the seals on the Vecat, giving about $200 \mathrm{in.}^{2}$ area between the seals. The actual area of the metal plate was smaller because of rounding of the plate corners and the need to allow extra room for the Vecat film to conform to the metal plate. The first three sets of panels were aged in air and then in helium. The fourth set of panels was aged only in helium, but with two variations. 


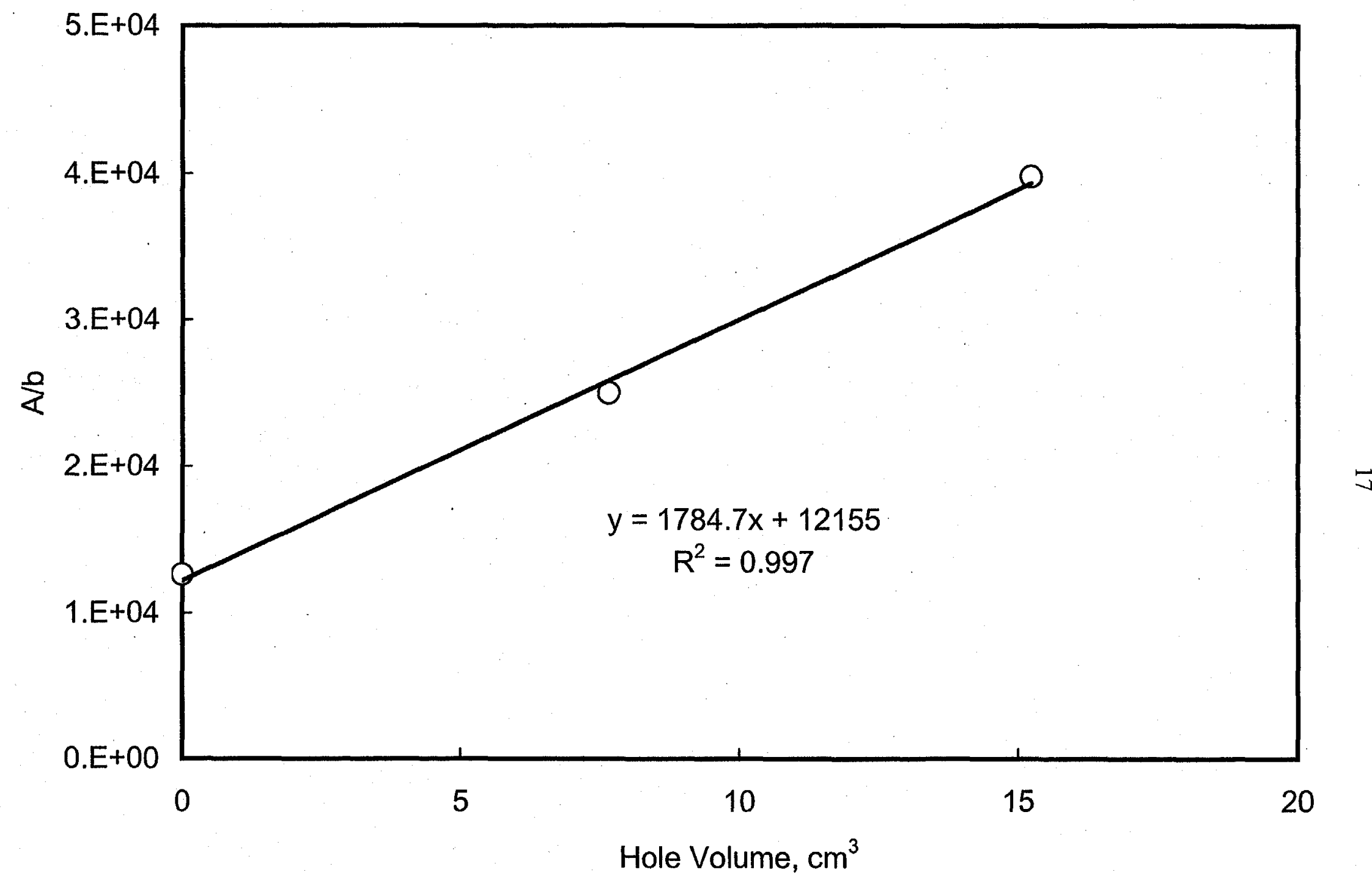

Figure 4. Data for Analysis of Void Volume in Tyvek Film for Vecat-Clad Panels Aged in Helium. $A / b$ is defined in Equation 13. 


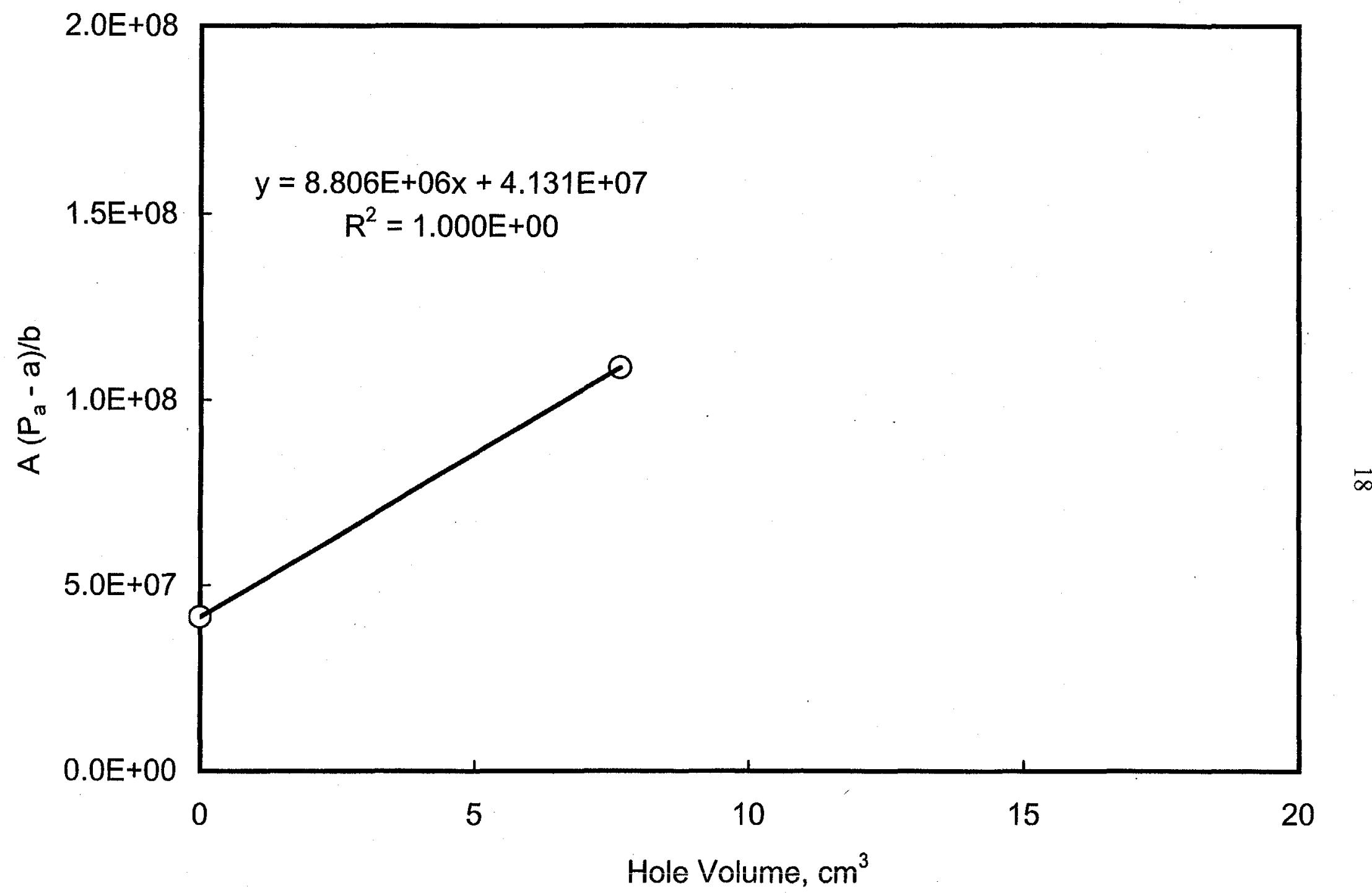

Figure 5. Data for Analysis of Void Volume in Tyvek Film for Vecat-Clad Panels Aged in Air. The quantity $A\left(P_{a}-a\right) / b$ is defined in Equation 12. 
The normal method for fabricating the test panels was to make a heat seal that was about 0.4 inches wide. The fourth set of panels was made with multiple heat seals so that the heat seal width was about 4 inches wide. This was done in an effort to determine the relative importance of permeance of gases through the heat seal layer as compared with permeance through the main area of the panel. This set of panels was aged in helium for two to eight days. The panels were then placed in air at reduced pressures and at a temperature of $90^{\circ} \mathrm{F}$ for about four months to allow the helium to permeate back out of the panels. In the meantime, some air permeated into the panels. The heat seals were then trimmed to 0.4 inches wide and the aging in helium was repeated.

The nomenclature for the panels is as follows: the letter V indicates the Vecat cladding, the Roman numeral (I, II, etc.) indicates a set of three plates, and the Arabic number indicates the individual panel with 1,2 , and 3 indicating zero, $2.5 \%$, and $5 \%$ porosity of the metal plates. The letters " $a$ " and " $b$ " for Panel Set IV indicate heat seal widths of 4 and 0.4 inches, respectively. Complete data for these panels are given in Appendix A.

Table 4 shows the values of $V_{\text {Tyvek }}$ that were obtained on the different panels. This shows that there is some variation in the values obtained for $\mathrm{V}_{\text {Tyvek}}$, but the values average about 5 to 6 $\mathrm{cm}^{3}$.

Table 4. Tyvek Void Volumes for Vecat-Clad Test Panels Aged in Air and Helium

\begin{tabular}{|c|c|c|}
\hline Panel Set & Void Volume $\left(\mathrm{cm}^{3}\right)$ for Air & Void Volume $\left(\mathrm{cm}^{3}\right)$ for Helium \\
\hline V-I & 6.1 & 6.0 \\
\hline V-II & 4.7 & 6.8 \\
\hline V-III & 6.2 & 5.2 \\
\hline V-IVa & - & 5.7 \\
\hline V-IVb & - & 4.9 \\
\hline Average & 5.7 & 5.7 \\
\hline
\end{tabular}


These values of $V_{\text {Tyvek }}$ were used with Equations 7 and 11 to calculate values for the film permeance. Table 5 gives the calculated helium permeances for two different assumptions on the area of the film. The first assumption is that the effective area is equal to the total area between the seals of the test panel, while the second assumption is that the effective area is equal to the projected area of the metal plate (both accounting for the two sides of the test panel). These two assumptions correspond to the upper and lower limits for the effective area for permeation, with the calculated permeance being inversely proportional to the assumed permeating area.

For comparison, independent measurements of helium permeance were performed by a commercial laboratory.[5] For two specimens, they obtained permeances of 2.02 and 2.25 $\mathrm{cc}(\mathrm{STP}) / 100 \mathrm{in} .^{2} \cdot \mathrm{atm} \cdot$ day at $90^{\circ} \mathrm{F}$, and 1.52 and $1.72 \mathrm{cc}(\mathrm{STP}) / 100 \mathrm{in} .^{2} \cdot$ atm $\cdot$ day at $75^{\circ} \mathrm{F}$. Comparison with the values in Table 5 shows reasonable agreement considering that the measurements were made by two entirely different methods, that there may be sample-to-sample variations in the film, and that permeation values for different films and different gases vary over orders of magnitude. The comparisons show that the values based on the area of the metal plate are probably more representative of the permeance of the film itself. This is supported by observations of the panels made with areas much larger than the plate. During aging of these panels in helium, blisters formed between the layers of Vecat in the region away from the metal plate. It is suspected that helium permeated through the Vecat, but did not readily travel in a lateral direction to the region of the metal plate. Also, the results for panel set IV with two greatly different seal widths show no difference due to seal width, indicating relatively little permeation of gas through the seal.

The uncertainty in absolute values of permeance due to the effective permeating area is recognized. However, for purposes of this report, the permeance values that are given correspond to the total area between the seals. After a few initial measurements with panels having a larger area, the remainder of the test panels were standardized to an area of 10 inches by 10 inches. (A convenient size since the units of permeance are given in terms of 100 square inches.) The permeance values then are effective values for that size of panel, and would include any permeation through the seals and through the film area not directly over the metal plate. Reduction of the difference between area between seals and area over the metal plate would be 
desirable, but is hindered by the need to allow space for the film to conform around the metal plate.

Table 6 shows similar data for the permeance to air. This table shows the same uncertainty due to the assumed effective permeation area. The values obtained with the largest internal volume (panels -3) are considered to be less reliable than the others because of the much smaller pressure rises. Comparing Table 6 with Table 5 shows the large difference due to permeating gas, with helium permeating several thousand times more rapidly than air.

Table 5. Permeance of Vecat-Clad Panels Aged in Helium

\begin{tabular}{|c|c|c|c|}
\hline Panel & Area between Seals, in. & $\begin{array}{c}\text { Permeance based on } \\
\text { Area between Seals }\end{array}$ & $\begin{array}{c}\text { Permeance based on } \\
\text { Area of Metal Plate }\end{array}$ \\
\hline V-I-1 & 312.5 & 1.1 & 2.4 \\
\hline V-I-2 & 312.8 & 1.2 & 2.6 \\
\hline V-I-3 & 317.8 & 1.2 & 2.5 \\
\hline V-II-1 & 316.4 & 1.2 & 2.4 \\
\hline V-II-2 & 316.0 & 1.2 & 2.6 \\
\hline V-II-3 & 317.0 & 1.2 & 2.5 \\
\hline V-III-1 & 203.0 & 1.7 & 2.3 \\
\hline V-III-2 & 201.0 & 1.7 & 2.3 \\
\hline V-III-3 & 202.8 & 1.7 & 2.3 \\
\hline V-IV-1a & 198.4 & 1.3 & 1.7 \\
\hline V-IV-2a & 199.0 & 1.2 & 1.6 \\
\hline V-IV-3a & 199.0 & 1.2 & 1.6 \\
\hline V-IV-1b & 198.4 & 1.2 & 1.6 \\
\hline V-IV-2b & 199.0 & 1.1 & 1.5 \\
\hline V-IV-3b & 199.0 & 1.2 & \\
\hline
\end{tabular}

Units for permeance are cc(STP)/100 in. ${ }^{2} \cdot$ atm $\bullet$ day

Area of metal plate $=150$ in. $^{2}$ 
Table 6. Permeance of Vecat-Clad Panels Aged in Air

\begin{tabular}{|c|c|c|c|}
\hline Panel & Area between Seals, in. ${ }^{2}$ & $\begin{array}{c}\text { Permeance based on } \\
\text { Area between Seals }\end{array}$ & $\begin{array}{c}\text { Permeance based on } \\
\text { Area of Metal Plate }\end{array}$ \\
\hline V-I-1 & 312.5 & 0.00027 & 0.00056 \\
\hline V-I-2 & 312.8 & 0.00027 & 0.00056 \\
\hline V-I-3 & 317.8 & 0.00010 & 0.00021 \\
\hline V-II-1 & 316.4 & 0.00024 & 0.00051 \\
\hline V-II-2 & 316.0 & 0.00024 & 0.00052 \\
\hline V-II-3 & 317.0 & 0.00020 & 0.00041 \\
\hline V-III-1 & 203.0 & 0.00045 & 0.00062 \\
\hline V-III-2 & 201.0 & 0.00046 & 0.00061 \\
\hline V-III-3 & 202.8 & 0.00022 & 0.00030 \\
\hline
\end{tabular}

Units for permeance are cc(STP)/100 in..$^{2}$ atm $\bullet$ day

Area of metal plate $=150 \mathrm{in}^{2}$

\subsubsection{Permeance Data for DuPont Films}

Test panels were made with DuPont films using the same methods described in Section

3.4.2. In most cases, the panels were evacuated to 0.5 torr overnight before making the final seal on the pouch. Pressure-time data are given in Appendix A, along with regression analyses, analyses of the values for $\mathrm{V}_{\text {Tyvek }}$ and calculations of permeance. Tables 7-13 give the air and helium permeance values and also give the number of days over which the experiments were run. The nomenclature for the test panels is similar to that described in Section 3.4.3: a capital letter indicates the type of cladding film, the Roman numeral (I, II, etc.) indicates a set of three plates, and the Arabic number indicates the individual panel with 1,2, and 3 indicating zero, 2.5\%, and $5 \%$ porosity of the metal plates.

The permeance values listed in Tables 7-13 are the effective values for the full area between the heat seals. Except for a few of the early sets of test panels, the panel size was standardized to give a 10 inch square area between the heat seals. The non-standard panels were in Sets A-I, A-II, and B-I. Some panels were run in both air and helium, but most of the panels 
Table 7. Permeance of Barrier Laminate E 92744-89-1

\begin{tabular}{|l|l|l|l|l|}
\hline Set/Specimen & \multicolumn{1}{|c|}{$\begin{array}{c}\text { Air } \\
\text { Permeance }\end{array}$} & \multicolumn{1}{|c|}{$\begin{array}{c}\text { Air Test } \\
\text { Time, days }\end{array}$} & $\begin{array}{c}\text { Helium } \\
\text { Permeance }\end{array}$ & $\begin{array}{c}\text { Helium Test } \\
\text { Time, days }\end{array}$ \\
\hline A-I-3 & 0.00070 & 238 & Not run & Not run \\
\hline A-II-1 & 0.00028 & $104^{*}$ & Not run & Not run \\
\hline A-II-2 & 0.00029 & 215 & 0.21 & 21 \\
\hline A-II-3 & 0.00029 & 179 & 0.21 & 30 \\
\hline A-III-1 & 0.00027 & 253 & 0.19 & 14 \\
\hline A-III-2 & 0.00025 & 254 & 0.18 & 26 \\
\hline A-III-3 & 0.00026 & 294 & 0.19 & 38 \\
\hline
\end{tabular}

* Leaked

Units for permeance are $\operatorname{cc}(\mathrm{STP}) / 100 \mathrm{in}^{2} \cdot{ }^{2}$ atm•day

Table 8. Permeance of Barrier Laminate E 92744-89-2 with Surlyn Layer

\begin{tabular}{|l|l|l|l|l|}
\hline Set/Specimen & \multicolumn{1}{|c|}{$\begin{array}{c}\text { Air } \\
\text { Permeance }\end{array}$} & $\begin{array}{c}\text { Air Test } \\
\text { Time, days }\end{array}$ & $\begin{array}{c}\text { Helium } \\
\text { Permeance }\end{array}$ & $\begin{array}{c}\text { Helium Test } \\
\text { Time, days }\end{array}$ \\
\hline B-I-1 & 0.0012 & 153 & Leaked & $1^{*}$ \\
\hline B-I-2 & 0.0025 & 153 & Leaked & $1^{*}$ \\
\hline B-I-3 & 0.0015 & 153 & 0.22 & 70 \\
\hline B-II-1 & 0.00034 & 181 & 0.16 & 9 \\
\hline B-II-2 & 0.00052 & 181 & 0.15 & 16 \\
\hline B-II-3 & 0.00042 & 181 & 0.16 & 16 \\
\hline
\end{tabular}

* Leaked

Units for permeance are cc(STP)/100 in..$^{2}$ atm •day 
Table 9. Permeance of E 51489-21-2 Film

\begin{tabular}{|l|l|l|l|l|}
\hline Set/Specimen & $\begin{array}{c}\text { Air } \\
\text { Permeance }\end{array}$ & $\begin{array}{c}\text { Air Test } \\
\text { Time, days }\end{array}$ & $\begin{array}{c}\text { Helium } \\
\text { Permeance }\end{array}$ & $\begin{array}{c}\text { Helium Test } \\
\text { Time, days }\end{array}$ \\
\hline C-I-1 & 0.00008 & 368 & 0.029 & 11 \\
\hline C-I-2 & 0.00005 & 368 & 0.034 & 24 \\
\hline C-I-3 & 0.00010 & 368 & 0.031 & 37 \\
\hline C-II-1 & 0.00007 & $504^{*}$ & Not run & Not run \\
\hline C-II-2 & $\Delta$ P too small & $43^{*}$ & Not run & Not run \\
\hline C-II-3 & $\Delta$ P too small & $165^{*}$ & Not run & Not run \\
\hline C-III-1 & Not run & Not run & 0.037 & $8^{*}$ \\
\hline C-III-2 & Not run & Not run & 0.041 & 22 \\
\hline C-III-3 & Not run & Not run & 0.038 & 30 \\
\hline
\end{tabular}

* Leaked

Units for permeance are $\operatorname{cc}(\mathrm{STP}) / 100 \mathrm{in.}^{2} \bullet$ atm $\bullet$ day

Table 10. Permeance of E 48662-146-1 Film

\begin{tabular}{|l|l|l|l|l|}
\hline Set/Specimen & \multicolumn{1}{|c|}{$\begin{array}{c}\text { Air } \\
\text { Permeance }\end{array}$} & $\begin{array}{c}\text { Air Test } \\
\text { Time, days }\end{array}$ & $\begin{array}{c}\text { Helium } \\
\text { Permeance }\end{array}$ & $\begin{array}{c}\text { Helium Test } \\
\text { Time, days }\end{array}$ \\
\hline D-I-1 & 0.00002 & 376 & 0.018 & 24 \\
\hline D-I-2 & 0.00002 & 376 & 0.018 & 37 \\
\hline D-I-3 & 0.00002 & 376 & - & 47 \\
\hline D-II-1 & 0.00003 & $448^{*}$ & Not run & Not run \\
\hline D-II-2 & $\Delta \mathrm{P}$ too small & $94 *$ & Not run & Not run \\
\hline D-II-3 & $\Delta \mathrm{P}$ too small & $325^{*}$ & Not run & Not run \\
\hline
\end{tabular}

* Leaked

Units for permeance are cc(STP)/100 in. ${ }^{2} \cdot$ atm $\bullet$ day 
Table 11. Permeance of E 48662-146-2 Film

\begin{tabular}{|l|l|l|l|l|}
\hline Set/Specimen & \multicolumn{1}{|c|}{$\begin{array}{c}\text { Air } \\
\text { Permeance }\end{array}$} & $\begin{array}{c}\text { Air Test } \\
\text { Time, days }\end{array}$ & $\begin{array}{c}\text { Helium } \\
\text { Permeance }\end{array}$ & $\begin{array}{c}\text { Helium Test } \\
\text { Time, days }\end{array}$ \\
\hline E-I-1 & 0.00004 & $137^{*}$ & Not run & Not run \\
\hline E-I-2 & 0.00004 & 391 & 0.019 & 37 \\
\hline E-I-3 & $\Delta$ P too small & 391 & 0.019 & $26^{*}$ \\
\hline E-II-1 & 0.00002 & $995^{* *}$ & Not run yet & Not run yet \\
\hline E-II-2 & 0.00002 & $548^{*}$ & Not run & Not run \\
\hline E-II-3 & Leaked & $0^{*}$ & Not run & Not run \\
\hline E-III-1 & Not run & Not run & 0.033 & 14 \\
\hline E-III-3 & Not run & Not run & 0.033 & 36 \\
\hline
\end{tabular}

* Leaked

** Still running as of $10 / 14 / 99$

Units for permeance are $\operatorname{cc}(\mathrm{STP}) / 100 \mathrm{in}^{2}{ }^{2}$ atm $\bullet$ day 
Table 12. Permeance of E 48662-153-1 Film

\begin{tabular}{|l|l|l|l|l|}
\hline Set/Specimen & \multicolumn{1}{|c|}{$\begin{array}{c}\text { Air } \\
\text { Permeance }\end{array}$} & $\begin{array}{c}\text { Air Test } \\
\text { Time, days }\end{array}$ & $\begin{array}{c}\text { Helium } \\
\text { Permeance }\end{array}$ & $\begin{array}{c}\text { Helium Test } \\
\text { Time, days }\end{array}$ \\
\hline F-I-1 & 0.00011 & $142^{*}$ & Not run & Not run \\
\hline F-I-2 & 0.00043 & $740^{*}$ & Not run & Not run \\
\hline F-I-3 & 0.00006 & $628^{*}$ & Not run & Not run \\
\hline F-II-1 & 0.00010 & $798^{* *}$ & Not run yet & Not run yet \\
\hline F-II-2 & 0.00008 & $798^{* *}$ & Not run yet & Not run yet \\
\hline F-II-3 & 0.00009 & $798^{* *}$ & Not run yet & Not run yet \\
\hline F-III-1 & 0.00008 & $233^{*}$ & Not run & Not run \\
\hline F-III-2 & $\Delta$ P too small & $35^{*}$ & Not run & Not run \\
\hline F-III-3 & 0.00008 & $771^{* *}$ & Not run yet & Not run yet \\
\hline F-IV-1 & 0.00012 & $645^{* *}$ & Not run yet & Not run yet \\
\hline F-IV-2 & 0.00010 & $645^{* *}$ & Not run yet & Not run yet \\
\hline F-IV-3 & 0.00011 & $645^{* *}$ & Not run yet & Not run yet \\
\hline F-V-1 & Not run & Not run & 0.028 & 14 \\
\hline F-V-2 & Not run & Not run & 0.026 & 36 \\
\hline F-V-3 & Not run & Not run & 0.027 & 49 \\
\hline
\end{tabular}

* Leaked

** Still running as of $10 / 14 / 99$

Units for permeance are cc(STP)/100 in. ${ }^{2} \cdot$ atm $\bullet$ day

Table 13. Permeance of VB 821985 Film

\begin{tabular}{|l|l|l|l|l|}
\hline Set/Specimen & \multicolumn{1}{|c|}{$\begin{array}{c}\text { Air } \\
\text { Permeance }\end{array}$} & \multicolumn{1}{|c|}{$\begin{array}{c}\text { Air Test } \\
\text { Time, days }\end{array}$} & $\begin{array}{c}\text { Helium } \\
\text { Permeance }\end{array}$ & $\begin{array}{c}\text { Helium Test } \\
\text { Time, days }\end{array}$ \\
\hline G-I-1 & 0.00060 & $287^{* *}$ & Not run yet & Not run yet \\
\hline G-I-2 & 0.00081 & $287^{* *}$ & Not run yet & Not run yet \\
\hline G-I-3 & 0.00065 & $287^{* *}$ & Not run yet & Not run yet \\
\hline
\end{tabular}

** Still running as of 10/14/99; Units for permeance are $\operatorname{cc}(\mathrm{STP}) / 100 \mathrm{in.} .^{2} \cdot{ }^{*} \cdot{ }^{\bullet}$ day 
were measured in one or the other of these gases. For some of the panels, the pressure rises in air were too small to be used to determine a permeance value. In other cases, permeance values determined with small pressure rises are given to only one significant figure.

Many of the panels leaked during testing, possibly due to repeated handling for the pressure measurements. However, other panels have survived for periods of up to $2 \frac{1}{2}$ years. After each pressure measurement, the aging chamber was pumped down to a pressure somewhat higher than the highest panel internal pressure and then backfilled with the test gas. This procedure was repeated a number of times. Limiting the pumpdown pressure in this way prevented the panels from ballooning as would occur if the pumpdown pressure were lower than the internal pressure, but may have still caused some fatigue of the claddings.

Table 14 compares the permeances of the DuPont films with that of Vecat. The first two films, with and without a Surlyn sealing layer, have air permeances that are comparable with that of Vecat, but the helium permeances are about an order of magnitude lower. The next film, $\mathrm{E}$ 51489-21-2, has an air permeance about five times lower than Vecat, and a helium permeance that is about 40 times lower than Vecat. The next two films, E 48662-146-1 and E 48662-146-2, have air permeances that are an order of magnitude lower than for Vecat, and helium permeances that are about two orders of magnitude lower than Vecat. For the next film, E 48662-153-1, ten panels had air permeances about four times lower than for Vecat, while one panel had a permeance in the same range as Vecat. This film had a helium permeance that was about 50 times lower than Vecat. Finally, the most recently received film, VB 821985, had an air permeance that was slightly higher than for Vecat.

Thus, the newly developed DuPont films have air permeances that are up to an order of magnitude better than Vecat, and helium permeances that are up to two orders of magnitude better. The difference between the two gases is probably due to the metallized layer in the DuPont films, since inert gases do not diffuse through metals at any temperature under purely thermal activation, while oxygen and nitrogen do.[6]

Table 15 compares the measured air permeances with values of oxygen transmission rate (OTR) measured by a commercial laboratory using a coulometric method.[5] The results are very similar, especially for the two E 48662-146 films. A more exact comparison is difficult because 
of the different test conditions and gases. The air values were measured at $90^{\circ} \mathrm{F}$ and zero relative humidity, while the oxygen values were measured at $73^{\circ} \mathrm{F}$ and $50 \%$ relative humidity. The effect of a lower temperature would be to lower the permeance, but a higher humidity could raise the permeance. Also, the permeance of polymers to oxygen is usually about a factor of four larger than for nitrogen [7], but there is about one-fourth as much oxygen as nitrogen in air.

Considering these factors, it is concluded that the OTR measurements tend to corroborate the air permeance measurements.

Table 14. Comparison of Permeances of Various Claddings

\begin{tabular}{|l|l|l|}
\hline Cladding Film & Air Permeance & Helium Permeance \\
\hline Vecat & $0.00024-0.00046^{*}$ & $1.1-1.7$ \\
\hline E 92744-89-1 & $0.00025-0.00070$ & $0.18-0.21$ \\
\hline E 92744-89-2 & $0.00034-0.0025$ & $0.15-0.22$ \\
\hline E 51489-21-2 & $0.00005-0.00010$ & $0.029-0.041$ \\
\hline E 48662-146-1 & $0.00002-0.00003$ & 0.018 \\
\hline E 48662-146-2 & $0.00002-0.00004$ & $0.019-0.033$ \\
\hline E 48662-153-1 & $0.00006-0.00012$ (10 panels) & $0.026-0.028$ \\
\hline VB 821985 & 0.00043 outlier (one panel) & \\
\hline
\end{tabular}

* Excludes data for panels with smallest pressure rises.

Units for permeance are cc(STP)/100 in..$^{2}$ atm•day

Table 15. Comparison of Air Permeance with Oxygen Transmission Rate (OTR)

\begin{tabular}{|l|l|l|}
\hline Cladding Film & Air Permeance* & OTR** \\
\hline E 48662-146-1 & $0.00002-0.00003$ & $0.000026-0.000032$ \\
\hline E 48662-146-2 & $0.00002-0.00004$ & $0.000013-0.000032$ \\
\hline E 48662-153-1 & $0.00006-0.00011$ & $0.000013-0.000045$ \\
\hline
\end{tabular}

${ }^{*}$ Measured at $90^{\circ} \mathrm{F}, 0 \%$ relative humidity; ${ }^{* *}$ Measured at $73^{\circ} \mathrm{F}, 50 \%$ relative humidity Units for permeance and OTR are cc(STP)/100 in. ${ }^{2} \bullet$ atm $\bullet$ day 


\subsection{Model Predictions of Aging of Panels}

The model given in section 3.4.1 was used to perform parametric analyses of the expected pressure rise due to permeation of air through the cladding of evacuated panel superinsulations. For these calculations, the superinsulation panel was taken to be one inch thick, to have $90 \%$ internal void volume, and to have a perfect initial vacuum. Figure 6 shows the calculated air pressure rise for assumed cladding permeances that span most of the values measured on the DuPont films. The values are calculated over a period of 20 years, which corresponds to the average lifetime of a refrigerator. The calculated pressure rises are small enough that Equation 5 holds and the pressure increases linearly with time and is proportional to the permeance.

The calculated pressure rises were combined with the curves of thermal resistivity versus pressure given in Figure 1 to calculate the thermal resistivity versus time. Figures 7 and 8 show the results of these calculations for fillers composed of precipitated silica powder and open-cell extruded polystyrene foam, respectively. Figure 7 shows that the loss of resistivity is relatively small for the silica powder filler. After 20 years, silica-filled panels would retain $99.4 \%, 99 \%$, $97 \%, 94 \%, 90 \%$, and $78 \%$ of their initial resistance for film permeances of $0.00001,0.00002$, $0.00005,0.0001,0.0002$, and $0.0005 \mathrm{cc}(\mathrm{STP}) / 100 \mathrm{in}^{2}{ }^{2} \cdot \mathrm{atm} \cdot$ day, respectively. For foam-filled panels, the retention of initial resistivity would be $93 \%, 88 \%, 74 \%, 61 \%, 46 \%$, and $30 \%$ for the same permeance values. Thus, the better films developed by DuPont have the potential to limit air permeation such that a large fraction of the initial thermal resistivity of evacuated panel superinsulation is retained over the lifetime of a refrigerator.

The above calculations have been limited to permeation of air under dry conditions. Transmission of water vapor through the claddings, changes in air permeance due to higher relative humidities, and outgassing of materials within the claddings would produce additional losses of thermal resistivity over time. However, it should be noted that getters can be used commercially to scavenge moisture and atmospheric gases and prolong the expected life of vacuum insulation panels.[8] 


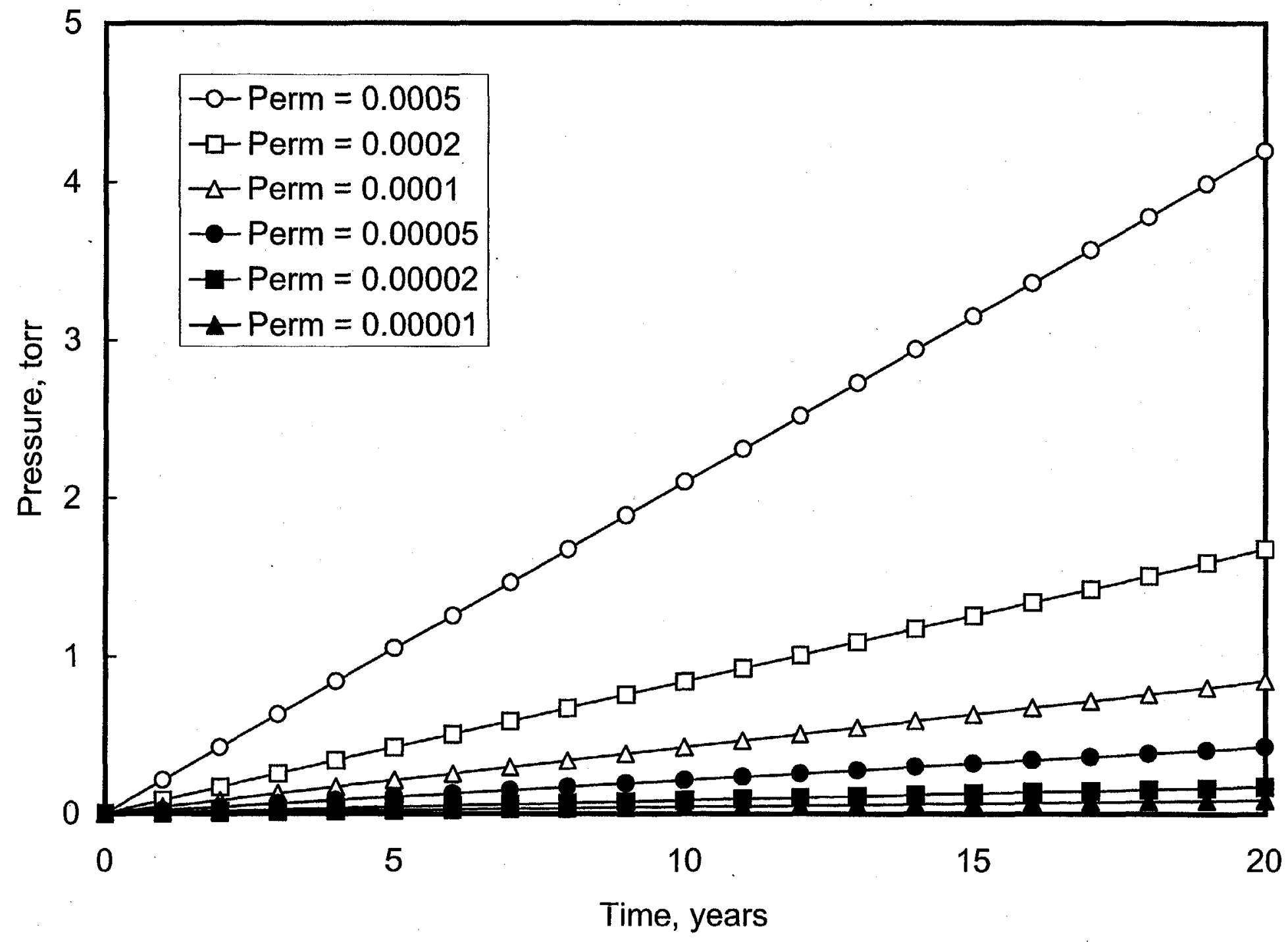

Figure 6. Effect of Cladding Permeance on Calculated Air Pressure Rise in One-InchThick Evacuated Panel Superinsulation with $90 \%$ Void Volume 


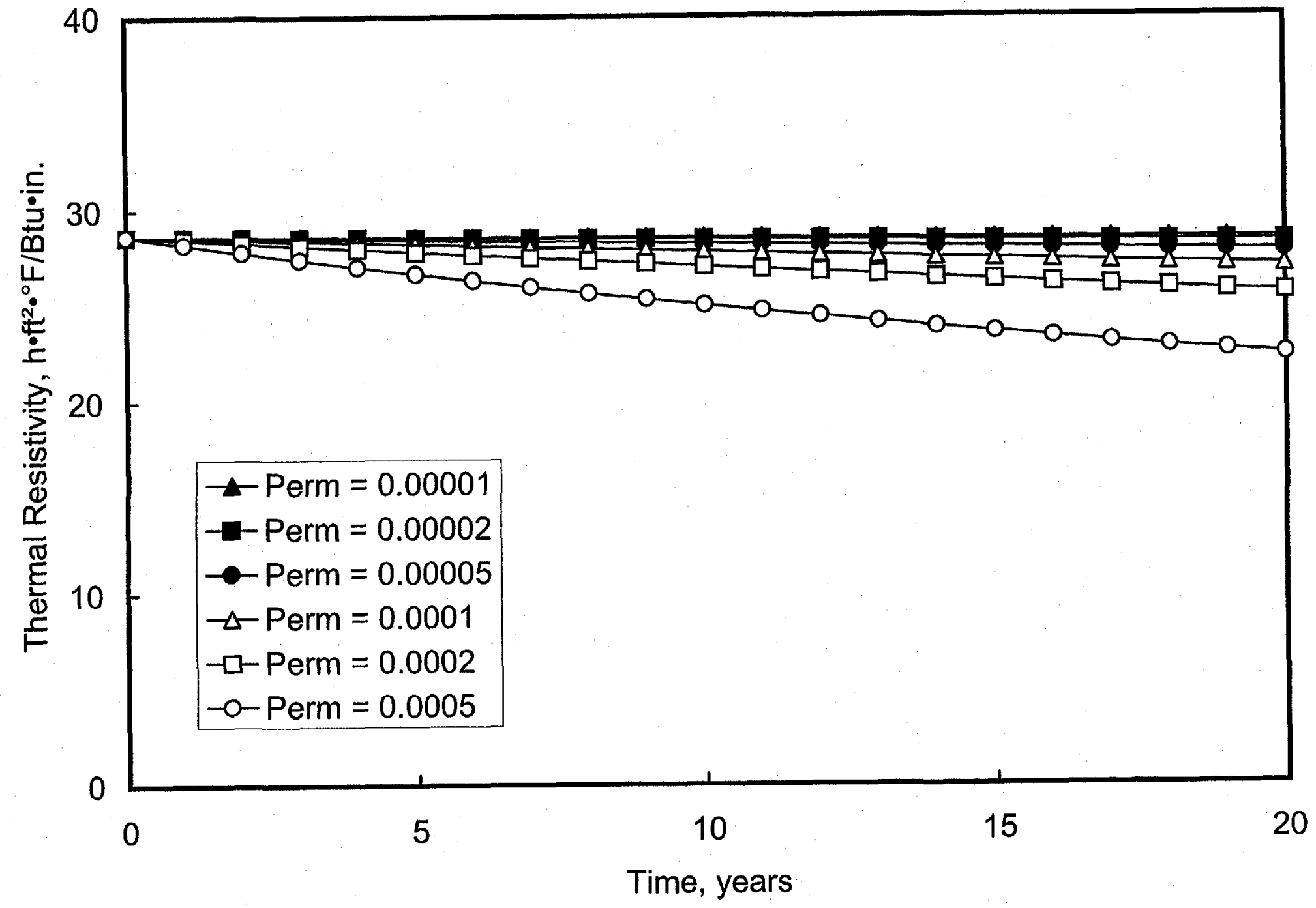

Figure 7. Effect of Cladding Permeance on Calculated Lifetime Thermal Resistivity of One-Inch-Thick Silica-Filled Evacuated Panel Superinsulation with $90 \%$ Void Volume 


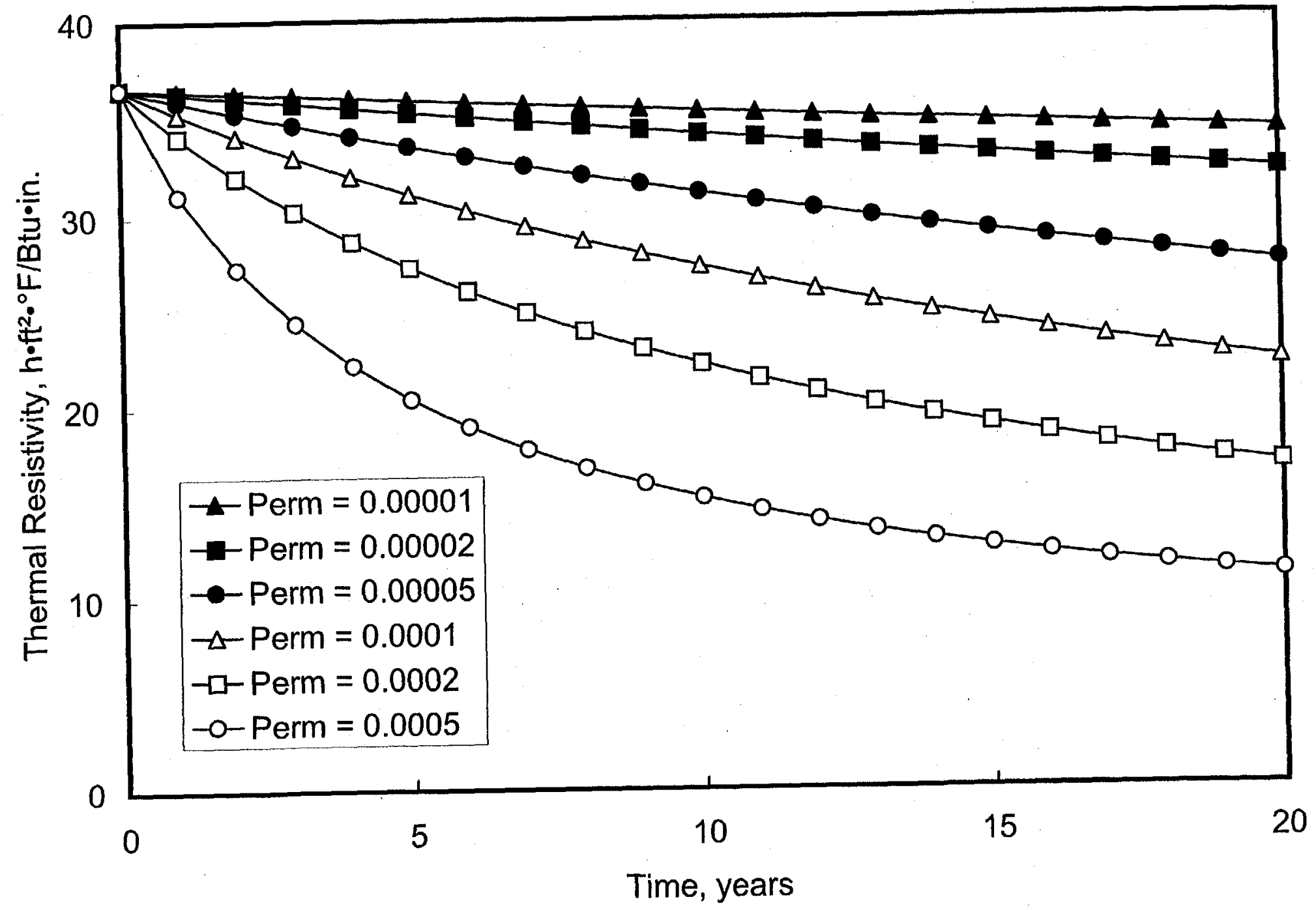

Figure 8. Effect of Cladding Permeance on Calculated Lifetime Thermal Resistivity of One-Inch-Thick Foam-Filled Evacuated Panel Superinsulation with $90 \%$ Void Volume 


\subsection{Thermal Resistivity Measurements on Vacuum Insulation Panels}

Thermal resistivity measurements were made over time for a few vacuum insulation panels made with DuPont films. Two panels were made at ORNL using the experimental films E 92744-89-1 and E 92744-89-2 without and with a Surlyn layer, using a precipitated silica powder for the filler. The powder was baked overnight at $250^{\circ} \mathrm{F}$, and then sealed in a Tyvek bag. The filled bag was inserted into a pouch made of the cladding film, this assembly was pumped to 0.5 torr for about one hour and then sealed under vacuum. Three panels were made by VacuPanel using the E 51489-21-2, E 48662-146-1, and E 48662-146-2 films, with an open-cell extruded polystyrene foam filler. According to VacuPanel, the panels were pumped down to 0.05 torr and sealed, but the pressure crept back up to about 2.5 torr, possibly because of outgassing of styrene monomer.

Thermal resistivity measurements were made using a heat flow meter apparatus that follows ASTM C 518.[9] The panels were sandwiched between sheets of foam rubber or semirigid fiberglass insulation, and the temperature differences across the panels were measured directly using thermocouples taped to the panel surfaces. Results of these measurements are given in Table 16, and thermal resistivities versus time are plotted in Figure 9. Over a period of about 3.6 years, the resistivity of the panel made with silica and the experimental film E 9274489-2 with the Surlyn sealant layer decreased by about $11 \%$, while the panel made with silica and the experimental film E 92744-89-1 without the Surlyn sealant layer decreased by about $19 \%$. The resistivity of the panel made with foam and the E-51489-21-2 film decreased less than 1\% over the first 1-1/2 years, but then decreased rapidly after that. The resistivity of the panel made with foam and the E-48662-146-1 film decreased by about $11 \%$ over a period of almost 3 years. The panel made with the E-48662-146-2 film leaked after the first measurements. In the absence of major leaks, the panels retained large fractions of their initial thermal resistivities over a period of a few years.

Thermal resistivity values measured on the panels were used with the curves given in Figure 1 to estimate the internal pressure in the panels, and these values are plotted in Figure 10. These calculations are based on the assumption that permeation of air is the reason for the decrease in thermal resistivity. These results suggest that the initial pressures in the panels made 
Table 16. Results of Thermal Resistivity Measurements on Vacuum Insulation Panels

\begin{tabular}{|l|c|c|c|}
\hline \multicolumn{1}{|c|}{ Cladding Film } & Filler & Date Measured & R/inch* \\
\hline E 92744-89-1 without Surlyn & Silica & $5-26-95$ & 22.9 \\
\hline (made 5-24-95, 0.700 in. thick) & & $6-16-98$ & 18.4 \\
\hline & & $1-20-99$ & 18.6 \\
\hline E 92744-89-2 with Suryln & Silica & $6-9-95$ & 18.8 \\
\hline (made 6-7-95, 0.676 in. thick) & & $6-16-98$ & 17.0 \\
\hline & & $1-21-99$ & 16.7 \\
\hline E 51489-21-2 & Foam & $12-11-96$ & 22.5 \\
\hline (made 11-13-96, 1.03 in. thick) & & $6-4-98$ & 22.4 \\
\hline & & $1-14-99$ & 8.81 \\
\hline & & $3-10-99$ & 7.77 \\
\hline Foam & & $10-20-99$ & 6.75 \\
\hline (made 11-20-96, 1.14 in. thick) & & $12-13-96$ & 22.9 \\
\hline & & $6-4-98$ & 22.1 \\
\hline & & $1-14-99$ & 21.9 \\
\hline & & $3-10-99$ & 21.6 \\
\hline & & $10-20-99$ & 20.4 \\
\hline & & $12-11-96$ & 22.9 \\
\hline & & & \\
\hline
\end{tabular}

* Units for thermal resistivity are $\mathrm{h} \cdot \mathrm{ft}^{2}{ }^{\circ} \mathrm{F} / \mathrm{Btu} \cdot \mathrm{in}$., or $\mathrm{R} /$ inch 


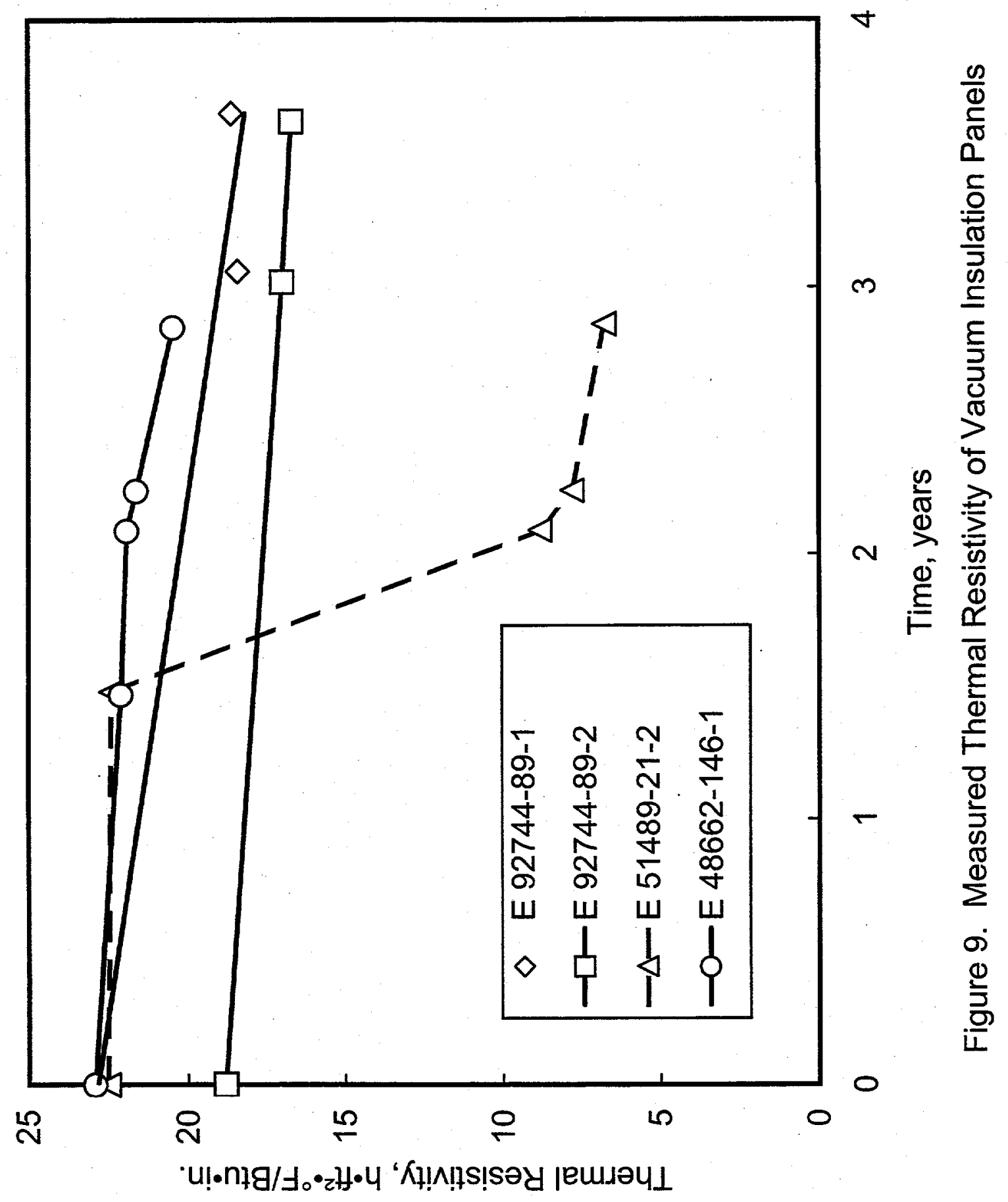




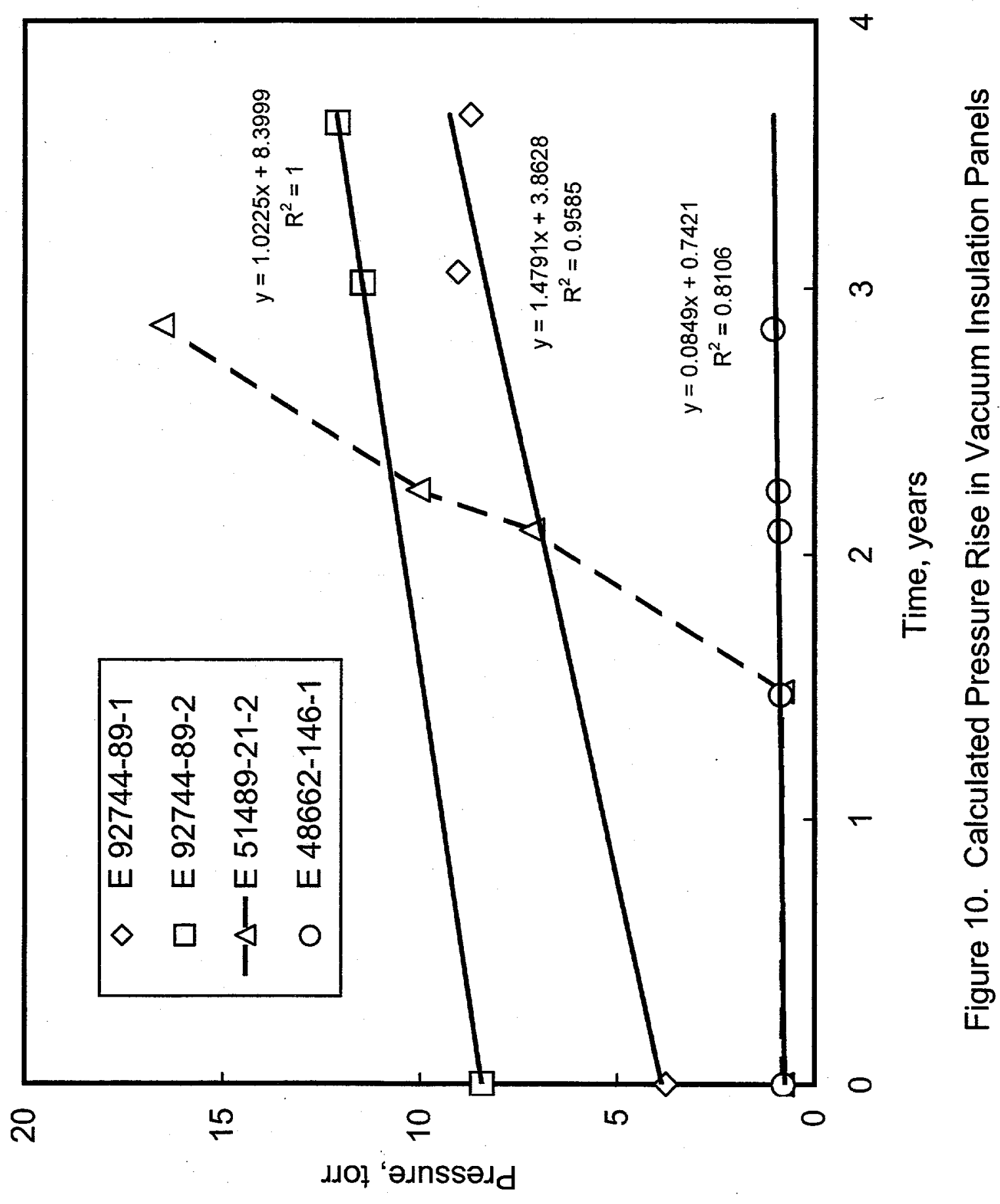


at ORNL with the silica filler were about 4 and 8 torr, while the initial pressures in the panels made by VacuPanel with the foam filler were less than 1 torr. The panel made with the E 5148921-2 film appears to have developed a slow leak that produced a pressure rise much more rapid than that with the other films, but yet not a sudden complete leak up to atmospheric pressure. The calculated pressure in the foam-filled panels is lower than the 2.5 torr initial pressure that VacuPanel had observed, and had attributed to styrene monomer. Since the molecular weight of styrene monomer is high, its thermal conductivity would be lower than that of air and it would have a small effect on the thermal resistivity. Hence the calculated pressure would not be sensitive to the presence of styrene monomer.

The equations shown on Figure 10 are linear regressions through the pressure-time values. Slopes of the regressions, along with panel thicknesses, were used with Equation 5 to estimate the apparent air permeances of the films. These calculations gave apparent air permeances of $0.0016,0.0025$, and $0.00023 \mathrm{cc}(\mathrm{STP}) / 100 \mathrm{in} .^{2} \cdot \mathrm{atm} \cdot$ day for the $\mathrm{E} 92744-89-1$, E 92744-89-2, and E 48662-146-1 films. These results show that the apparent permeance of the E 48662-146-1 film is about an order of magnitude lower than that of the E 92744-89 films, in agreement with the relative values given in Table 14. However, the permeance values inferred from thermal measurements on vacuum insulation panels are about an order of magnitude larger than the air permeances measured with the vacuum panels containing rigid fillers. Part of this difference may be due to the influence of ambient humidity. While the rigid-filler vacuum panels were aged in closed chambers containing dry air, the vacuum insulation panels were exposed to humid air in the laboratory. An increase in relative humidity can result in an increased air permeance for some polymers. However, the oxygen transmission rates shown in Table 15 were measured with $50 \%$ relative humidity on both sides of the films, and are in reasonable agreement with the measured air permeances. This suggests that the decreases in thermal resistivity are probably not due to permeation of air into the panels.

The other effect of ambient humidity is the permeation of water vapor through the film. The water vapor transmission rate given in Table 1 is 0.0003 grams $/ 100$ in. ${ }^{2}$-day with $50 \%$ relative humidity on one side and $0 \%$ on the other side. Over a period of three years, about 0.6 grams of water would permeate into a vacuum panel having an area of 100 in. $^{2}$ per side. Most of 
this water would be expected to be absorbed (or adsorbed) by the desiccant packages that were contained in the panels made by VacuPanel or by the precipitated silica powder within the ORNL panels. A mass of 0.6 grams of water would correspond to about $0.3 \%$ of the mass of the silica in the ORNL panels (the mass of silica in the test panels was about 220 grams). During bake-out of the silica powder before making the panels, the powder lost about $6 \%$ of its mass. Assuming that $6 \%$ is the equilibrium moisture content at about $50 \%$ relative humidity, and assuming that the sorption curve for silica powder is linear, 0.6 grams of water would correspond approximately to a water vapor pressure of 0.4 torr (note, the vapor pressure of water at $70^{\circ} \mathrm{F}$ and $50 \% \mathrm{RH}$ is 9.4 torr). With this pressure, only about $0.1 \%$ of the mass of water would be in the vapor phase. The pressure rise of 0.4 torr is smaller than the rises of 3-4 torr estimated for the silica-filled panels. However, based on comparisons of air permeances, the water vapor transmission rates for the E 92744-89 films would be expected to be several times larger than those for the film represented in Table 1. The associated pressure rises would then be of the same magnitude as those estimated for the panels, suggesting that the decreases in thermal resistivity are probably due to water vapor transmission. A more detailed analysis would require consideration of water vapor transmission rates for the films used in the test panels, the mean free path of water vapor molecules (which is about $2 / 3$ that of air), the thermal conductivity of water vapor (which is about $20 \%$ lower than that for air), and the equilibrium sorption isotherms for precipitated silica powder and the desiccant packages used in the panels.

\subsection{Effect of Edge Conduction on Performance of Vacuum Insulation Panels}

While vacuum insulation panels with claddings based on polymers have the disadvantage of gradual loss of performance due to permeation of gases, they have the advantage over impermeable metallic claddings in that they do not present a thermal short circuit around the high-resistivity filler. To explore this effect, thermal measurements and analyses were performed for two foam-filled panels made by VacuPanel, one with a cladding of E 48662-146-1 and the other with a cladding of a commercial film that consists of polymer layers with an aluminum foil layer. 
The thermal measurements were made using a heat flow meter apparatus that contains an array of heat flux transducers. For these measurements, the panels were sandwiched between layers of semi-rigid fiberglass of known thermal properties, and the temperature differences across the panels were measured directly using thermocouples taped to the faces of the panels. Lateral dimensions were $8.25 \mathrm{in}$. by $11 \mathrm{in}$. for the $\mathrm{E} 48662-146-1$ panel and $11.75 \mathrm{in}$. square for the foil panel. The heat flux transducers were 4 inches square and measured the heat flux through the vacuum panels as well as that through the surrounding fiberglass insulation.

Data from these tests were analyzed using a special purpose finite difference heat conduction computer program. The program uses knowledge of the specimen assembly geometry, boundary temperatures, and the thermal conductivity of the cladding, filler, and surrounding material to calculate the heat flux distribution at the locations of the heat flux transducers. The thermal conductivity of the filler material will generally not be known, and the thermal conductivity of the cladding may or may not be known. Starting with initial estimates for the unknown thermal conductivities, the computer program systematically varies these conductivities and searches for the values that give the best match (in the least squares sense) between the calculated and measured heat flux distributions.

The program estimated the thermal resistivity of the filler to be 20.3 and 33.3 $\mathrm{h} \cdot \mathrm{ft}^{2} \bullet{ }^{\circ} \mathrm{F} / \mathrm{Btu} \cdot \mathrm{in}$. for the panels clad with E 48662-146-1 and the commercial foil film, respectively. The difference is probably due to a better vacuum in the panel with the foil film. The program also estimated the cladding thermal conductivities to be 5.7 and $110 \mathrm{Btu} \cdot \mathrm{in} . / \mathrm{h} \bullet \mathrm{ft}^{2} \bullet^{\circ} \mathrm{F}$ for the E 48662-146-1 and foil films, respectively. The foil-type film was 0.0033 inches thick and contained a layer of aluminum foil that was $6 \mu \mathrm{m}(0.00024$ in.) thick. Using literature values of $1664 \mathrm{Btu} \cdot \mathrm{in} . / \mathrm{h} \cdot \mathrm{ft}^{2} \bullet^{\circ} \mathrm{F}$ for aluminum [10] and $1.2 \mathrm{Btu} \cdot \mathrm{in} . / \mathrm{h} \cdot \mathrm{ft}^{2} \bullet^{\circ} \mathrm{F}$ for polyester [11], the thermal conductivity parallel to the film may be estimated to be $120 \mathrm{Btu} \cdot \mathrm{in} . / \mathrm{h} \cdot \mathrm{ft}^{2} \bullet^{\circ} \mathrm{F}$, in good agreement with the computer-generated value. The E 48662-146-1 film was 0.0015 in. thick, in which case the computer-generated value of $5.7 \mathrm{Btu} \cdot \mathrm{in} . / \mathrm{h} \bullet \mathrm{ft}^{2} \bullet^{\circ} \mathrm{F}$ would be consistent with an aluminum film thickness of about $1000 \AA$. This aluminum thickness is somewhat larger than the actual thicknesses in the cladding film, indicating that the computer-generated overall thermal conductivity for the E 48662-146-1 is probably an overestimate. Thus the thermal conductance 
(product of film thickness and average thermal conductivity) of the foil-type film was more than a factor of 40 larger than that of the E 48662-146-1 film.

Using the best fit thermal conductivities for the cladding, the program then calculated the overall thermal resistivity of vacuum insulation panels of various sizes, accounting for the effects of heat conduction around the edges of the panel. Results of these calculations are shown in Figure 11 for a filler with a thermal resistivity of $33.3 \mathrm{~h} \cdot \mathrm{ft}^{2}{ }^{\circ} \mathrm{F} / \mathrm{Btu} \cdot \mathrm{in}$. The horizontal line is the thermal resistivity of the filler, and corresponds to the overall thermal resistivity of a vacuum insulation panel of infinite size. Heat conduction through the cladding with aluminum foil causes large decreases in the overall panel thermal resistivity. For example, the effect of heat conduction through the aluminum foil is to decrease the overall panel resistivity by $68 \%$ for a one foot square panel, while the resistivity of a similar panel with the E 48662-146-1 cladding is reduced by only $11 \%$. 


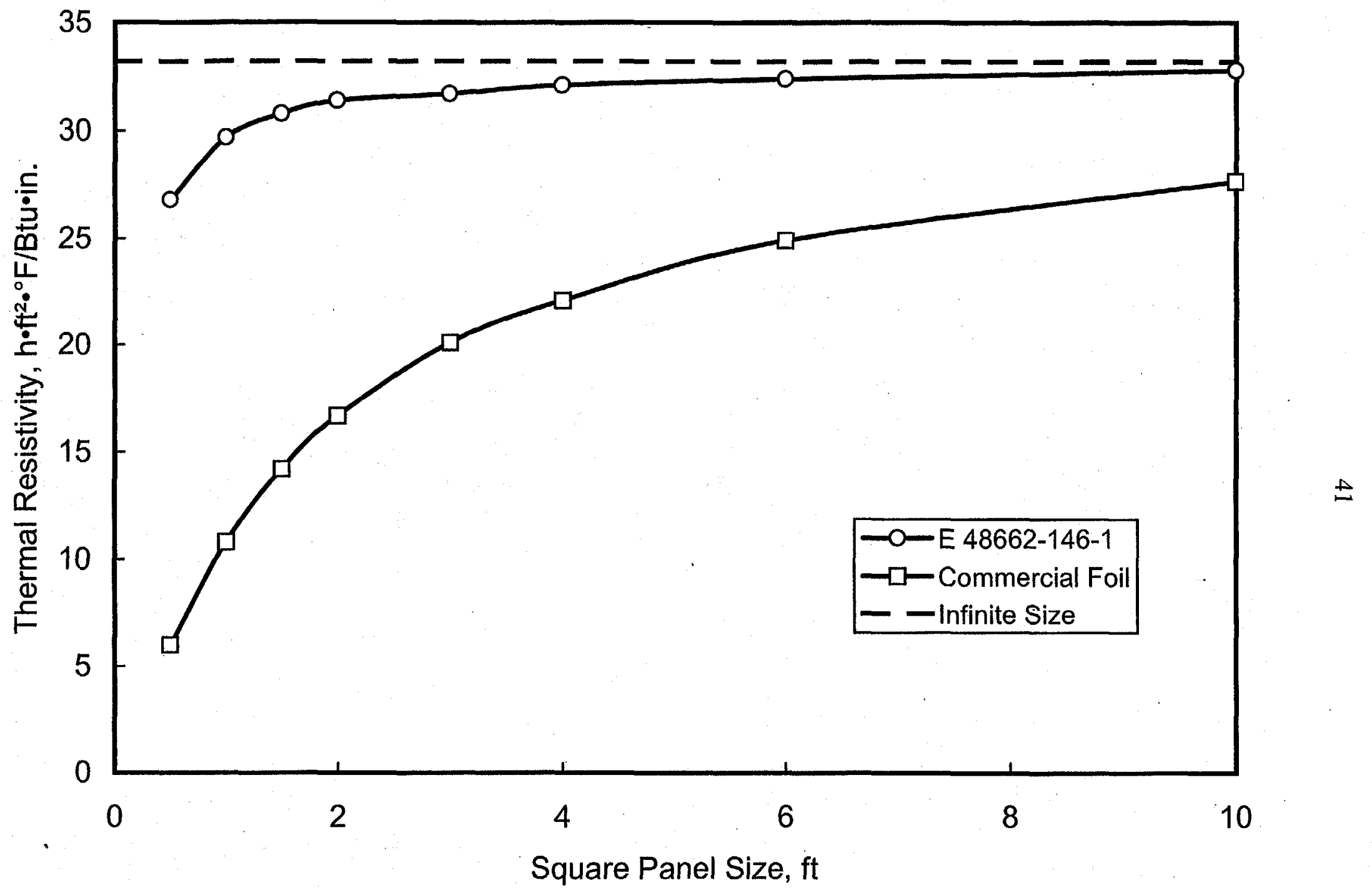

Figure 11. Calculated Effect of Edge Heat Conduction on Thermal Performance of Vacuum Insuation Panels 


\section{INVENTIONS}

DuPont has applied for a patent on an invention titled "Improved Oxygen Barrier Composite Film Structure."

\section{COMMERCIALIZATION POSSIBILITIES}

DuPont is proceeding with commercialization of the vacuum barrier films developed under this CRADA, and VacuPanel is proceeding with commercialization of evacuated panel superinsulations.

\section{PLANS FOR FUTURE COLLABORATIONS}

While there are no definite plans for future collaborations, ORNL, DuPont, and VacuPanel will continue to interact as the technology of evacuated panel superinsulation continues to be mature, and will attempt to identify areas for future collaborations.

\section{CONCLUSIONS}

New polymeric films for use as claddings on vacuum insulation panels were developed and evaulated. The films incorporated vacuum metallized coating layers and high-barrier polymer layers to hinder permeation of gases. The films were found to be suitable for use in manufacturing vacuum insulation panels. Measured air permeances for the new films were up to an order of magnitude lower than those of a commercially available all-polymer film. Analyses of aging of vacuum insulation panels due to air permeation showed that the better of the new films had the potential to limit air permeation such that a large fraction of the initial thermal resistivity of vacuum insulation panels would be retained over the 20-year lifetime of a

refrigerator. Retention of initial thermal resistivity would be better with a panel filler composed of precipitated silica powder than with open-cell foam. Measurements of thermal resistivity on test vacuum insulation panels showed that, in the absence of major leaks, 80 to $90 \%$ of the initial thermal resistivity was retained over a period of three years. It is hypothesized that the loss of resistivity is due to permeation of water vapor through the claddings. Analyses of the effects of heat conduction around the edges of vacuum insulation panels showed that the overall thermal 
resistivity of panels made with the new films would be reduced by only small amounts (e.g., $11 \%$ for a 1-ft-square panel) from that of an infinite-sized panel, while panels made with a commercially available film containing a layer of aluminum foil would have a much larger reduction (e.g., $68 \%$ for a $1-\mathrm{ft}$-square panel).

\section{ACKNOWLEDGMENTS}

Funding for this CRADA was provided by the E. I. DuPont de Nemours and Company, VacuPanel, Inc., and the U.S. Department of Energy, Office of Building Technology, State and Community Programs, under contract number DE-AC05-96OR22464 with the Oak Ridge National Laboratory, managed by Lockheed Martin Energy Research Corp. Many persons at DuPont contributed to this project. Particular thanks are due to Dr. Al Topolski (now retired from DuPont) and for leadership and championing of this project. Therese Stovall of ORNL is thanked for her analyses of the effects of edge heat conduction in vacuum insulation panels. Dr. Thomas Kollie of ORNL (now retired from ORNL) is also thanked for his leadership during the early phases of this project.

\section{REFERENCES}

1. D. W. Yarbrough, "Literature Review: Heat Transfer Through Two-Phase Insulation Systems Consisting of Powders in a Continuous Gas Phase," EPA-600-R-92-203; ORNL/M-2426, Oak Ridge National Laboratory, Oak Ridge, TN, December 1992.

2. A. Roth, Vacuum Technology, 2nd Ed., pg. 28, North-Holland Publishing Company, New York (1982).

3. G. M. Ludtka, T. G. Kollie, D. C. Watkins, and D. G. Walton, "Gas Permeability Measurements for Film Envelope Materials," U.S. Patent 5,750,882, issued May 12, 1998.

4. T. G. Kollie and L. H. Thacker, "Gauge for Nondestructive Measurement of the Internal Pressure in Powder-Filled Evacuated Panel Superinsulation," Review of Scientific. Instruments, Vol. 63, pp. 5774-5779 (1992).

5. Measurements were made by Modern Controls, Inc., Minneapolis, Minnesota. 
6. A. Roth, Vacuum Technology, 2nd Ed., pg. 167, North-Holland Publishing Company, New York (1982).

7. D. W. Van Krevelen, Properties of Polymers: Their Correlation with Chemical Structure; Their Numerical Estimation and Prediction from Additive Group Contributions, 3rd Ed., p. 555, Elsevier, New York (1990).

8. P. della Porta, "Gas Problem and Gettering in Sealed-Off Vacuum Devices," Vacuum, Vol. 47. Pp. 771-777 (1996).

9. C 518, "Standard Test Method for Steady-State Heat Flux Measurements and Thermal Transmission Properties by Means of the Heat Flow Meter Apparatus," in 1998 Annual Book of ASTM Standards, Vol. 04.06, pp. 163-174, American Society for Testing and Materials, Philadelphia (1998).

10. K. E. Wilkes and R. W. Powell, "Thermal Conductivity of Aluminum between 78 and 373 K," in Thermal Conductivity-Proceedings of the Seventh Conference (D. R. Flynn and B. A. Peavy, Editors), NBS Spec. Pub. 302, p. 293 (1968).

11. D. W. Van Krevelen, Properties of Polymers: Their Correlation with Chemical Structure; Their Numerical Estimation and Prediction from Additive Group Contributions, 3rd Ed., p. 527, Elsevier, New York (1990). 
Appendix A

Tabulation of Pressure-Time Data for Permeance Test Panels 

Film:

Panel:

E 92744-89-1

Gas:

A-I-3

Internal Volume:

Air

$14.72 \mathrm{~cm}^{3}$

$\begin{array}{rrrr}\text { Date } & \text { Time } & \text { Hours } & P \text {, torr } \\ \text { 1/13/95 } & 11: 00 \mathrm{AM} & 0 & 4.7 \\ 1 / 20 / 95 & 11: 00 \mathrm{AM} & 168 & 5.2 \\ 1 / 27 / 95 & 11: 00 \mathrm{AM} & 335 & 5.7 \\ 2 / 3 / 95 & 9: 30 \mathrm{AM} & 502.5 & 5.7 \\ 2 / 10 / 95 & 9: 00 \mathrm{AM} & 670 & 6.2 \\ 2 / 24 / 95 & 9: 00 \mathrm{AM} & 1006 & 6.7 \\ 3 / 10 / 95 & 9: 00 \mathrm{AM} & 1342 & 7.8 \\ 3 / 24 / 95 & 9: 00 \mathrm{AM} & 1678 & 9.0 \\ 4 / 12 / 95 & 9: 00 \mathrm{AM} & 2134 & 9.5 \\ 5 / 11 / 95 & 9: 00 \mathrm{AM} & 2830 & 10.4 \\ 6 / 8 / 95 & 9: 00 \mathrm{AM} & 3502 & 12.2 \\ 6 / 16 / 95 & 2: 30 \mathrm{PM} & 3700 & 12.1 \\ 6 / 19 / 95 & 1: 00 \mathrm{PM} & 3770.5 & 12.6 \\ 6 / 30 / 95 & 12: 00 \mathrm{PM} & 4033.5 & 13.8 \\ 7 / 14 / 95 & 5: 00 \mathrm{PM} & 4374.5 & 14.0 \\ 7 / 29 / 95 & 4: 10 \mathrm{PM} & 4733.7 & 14.3 \\ 8 / 11 / 95 & 1: 30 \mathrm{PM} & 5043 & 15.8 \\ 8 / 25 / 95 & 7: 00 \mathrm{AM} & 5372.5 & 16.5 \\ 9 / 8 / 95 & 6: 30 \mathrm{AM} & 5708 & 18.1\end{array}$

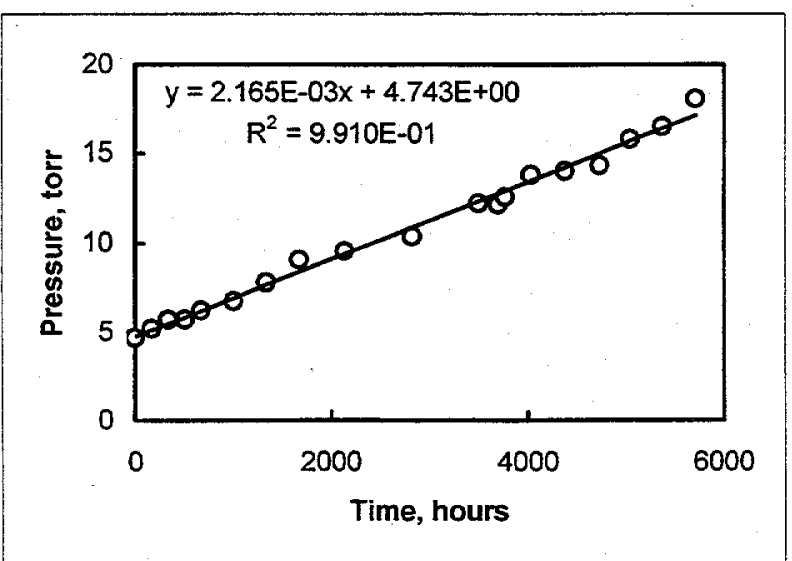


Film:

E 92744-89-1

Panel Set:

A-I

Gas:

Air

$$
P=a+b t
$$

\begin{tabular}{|c|c|c|c|c|c|}
\hline $\begin{array}{l}\text { Panel } \\
\text { A-I-3 }\end{array}$ & $\begin{array}{l}V, c c \\
14.72\end{array}$ & $\begin{array}{r}A, \text { in. }^{2} \\
169\end{array}$ & $\begin{array}{rr}a & b \\
4.743 & 2.165 E-03\end{array}$ & $\begin{array}{r}A^{*}(P a m b-a) / b \\
6.091 E+07\end{array}$ & $\begin{array}{c}\text { Permeance } \\
0.00070\end{array}$ \\
\hline \multicolumn{6}{|c|}{ Permeance units $=c c(S T P) / 100$ in..$^{2} \cdot$ atm $\cdot$ day } \\
\hline
\end{tabular}


Film:

E 92744-89-1

Panel:

A-II-1

Gas:

Air

Internal Volume: $\quad 0 \mathrm{~cm}^{3}$

$\begin{array}{rrrr}\text { Date } & \text { Time } & \text { Hours } & \text { P, torr } \\ 6 / 23 / 95 & 12: 45 \mathrm{PM} & 0 & 9.9 \\ 6 / 26 / 95 & 1: 00 \mathrm{PM} & 71.75 & 16.3 \\ 6 / 30 / 95 & 12: 00 \mathrm{PM} & 166.75 & 17.7 \\ 7 / 14 / 95 & 4: 55 \mathrm{PM} & 507.67 & 20.7 \\ 7 / 29 / 95 & 4: 10 \mathrm{PM} & 866.9 & 22.6 \\ 8 / 11 / 95 & 1: 30 \mathrm{PM} & 1176.2 & 24.5 \\ 8 / 25 / 95 & 7: 00 \mathrm{AM} & 1505.7 & 27.9 \\ 9 / 8 / 95 & 6: 30 \mathrm{AM} & 1841.2 & 30.0 \\ 9 / 20 / 95 & 4: 30 \mathrm{PM} & 2139.2 & 32.9 \\ 10 / 5 / 95 & 5: 15 \mathrm{PM} & 2499.95 & 35.5\end{array}$

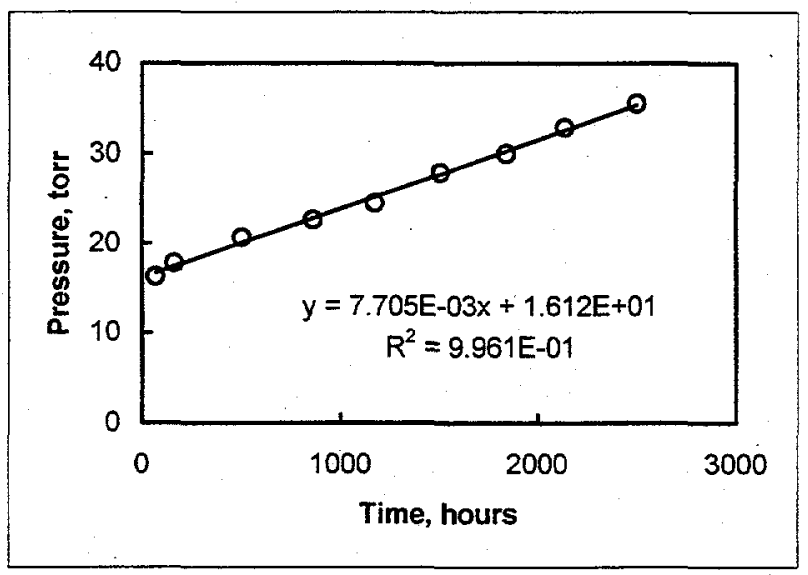

Note: data point at $t=0$ deleted from plot and regression 
Film:

Panel:

E 92744-89-1

Gas:

A-11-2

Internal Volume: $\quad 7.66 \mathrm{~cm}^{3}$

$\begin{array}{rrrr}\text { Date } & \text { Time } & \text { Hours } & \mathrm{P} \text {, torr } \\ 6 / 16 / 95 & 2: 30 \mathrm{PM} & 0 & 9.3 \\ 6 / 19 / 95 & 1: 00 \mathrm{PM} & 70.5 & 15.8 \\ 6 / 23 / 95 & 12: 45 \mathrm{PM} & 166.25 & 16.2 \\ 6 / 30 / 95 & 12: 00 \mathrm{PM} & 333.5 & 16.0 \\ 7 / 14 / 95 & 4: 55 \mathrm{PM} & 674.42 & 16.8 \\ 7 / 29 / 95 & 4: 10 \mathrm{PM} & 1033.7 & 18.0 \\ 8 / 11 / 95 & 1: 30 \mathrm{PM} & 1343 & 18.1 \\ 8 / 25 / 95 & 7: 00 \mathrm{AM} & 1672.5 & 19.6 \\ 9 / 8 / 95 & 6: 30 \mathrm{AM} & 2008 & 22.1 \\ 9 / 20 / 95 & 4: 30 \mathrm{PM} & 2306 & 22.3 \\ 10 / 5 / 95 & 5: 15 \mathrm{PM} & 2666.75 & 24.3 \\ 11 / 11 / 95 & 4: 35 \mathrm{PM} & 3554.08 & 25.9 \\ 1 / 17 / 96 & 7: 30 \mathrm{AM} & 5153 & 30.9\end{array}$

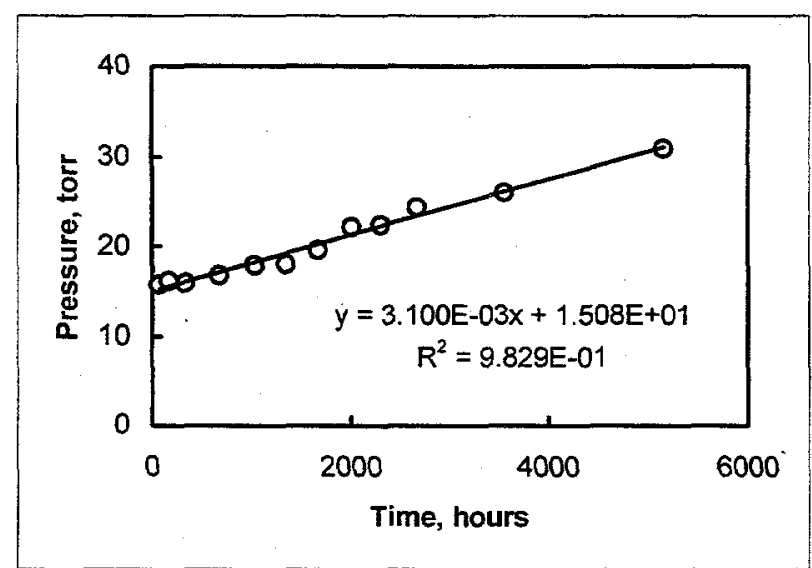

Note: data point at $t=0$ deleted from plot and regression 
Film:

E 92744-89-1

Panel:

A-1I-3

Gas:

Air

Internal Volume: $\quad 15.00 \mathrm{~cm}^{3}$

$\begin{array}{rrrr}\text { Date } & \text { Time } & \text { Hours } & P, \text { torr } \\ 7 / 22 / 95 & 1: 45 \mathrm{PM} & 0 & 6.2 \\ 7 / 29 / 95 & 4: 10 \mathrm{PM} & 168.2 & 4.8 \\ 8 / 11 / 95 & 1: 30 \mathrm{PM} & 477.5 & 4.9 \\ 8 / 25 / 95 & 7: 00 \mathrm{AM} & 807 & 7.8 \\ 9 / 8 / 95 & 6: 30 \mathrm{AM} & 1142.5 & 8.3 \\ 9 / 20 / 95 & 4: 30 \mathrm{PM} & 1440.5 & 10.0 \\ 10 / 5 / 95 & 5: 15 \mathrm{PM} & 1801.25 & 8.8 \\ 11 / 11 / 95 & 4: 35 \mathrm{PM} & 2688.58 & 9.9 \\ 1 / 17 / 96 & 7: 30 \mathrm{AM} & 4287.5 & 13.5\end{array}$

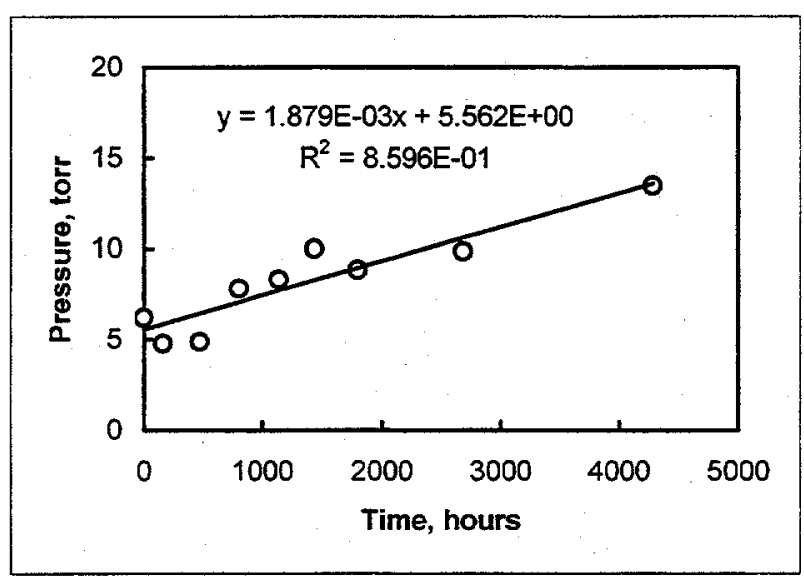


Film:

E 92744-89-1

Panel Set:

A-II

Gas:

Air

$P=a+b t$

Panel

$V, c c$

$A$, in. ${ }^{2}$

a

b $A^{*}($ Pamb-a $) / b$ Permeance

A-II-1

0.00

367.5

A-II-2

7.66

370.0

16.12 7.705E-03

15.08 3.100E-03

3.667E+07

0.00028

A-II-3

15.00

359.0

$5.562 \quad 1.879 E-03$

$9.189 E+07$

0.00029

$1.489 E+08$

0.00029

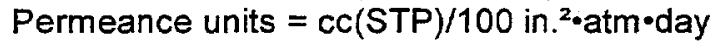

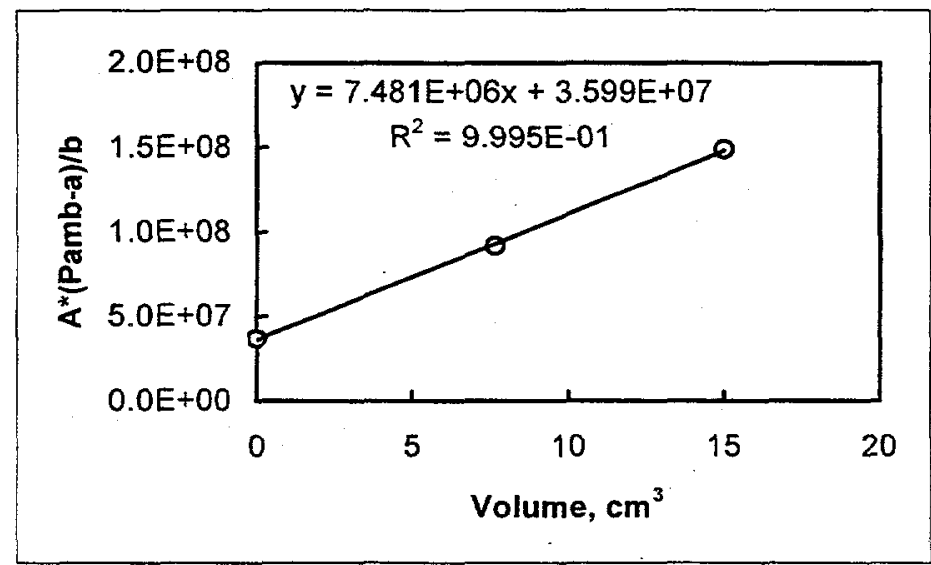

$V_{0}=$

$4.8 \mathrm{~cm}^{3}$ 
Film:

Panel:

Gas:

Internal Volume:
E 92744-89-1

A-II-2

Helium

$7.66 \mathrm{~cm}^{3}$

$\begin{array}{rrrr}\text { Date } & \text { Time } & \text { Hours } & P \text {, torr } \\ 1 / 17 / 96 & 11: 00 \mathrm{AM} & 0 & 30.9 \\ 1 / 17 / 96 & 5: 00 \mathrm{PM} & 6 & 39.8 \\ 1 / 18 / 96 & 1: 45 \mathrm{PM} & 26 & 72.1 \\ 1 / 19 / 96 & 3: 30 \mathrm{PM} & 51 & 112.1 \\ 1 / 22 / 96 & 4: 15 \mathrm{PM} & 123 & 220.9 \\ 1 / 26 / 96 & 3: 00 \mathrm{PM} & 217 & 333.5 \\ 1 / 31 / 96 & 4: 10 \mathrm{PM} & 337.4 & 442.6 \\ 2 / 7 / 96 & 1: 30 \mathrm{PM} & 502.7 & 548.1\end{array}$
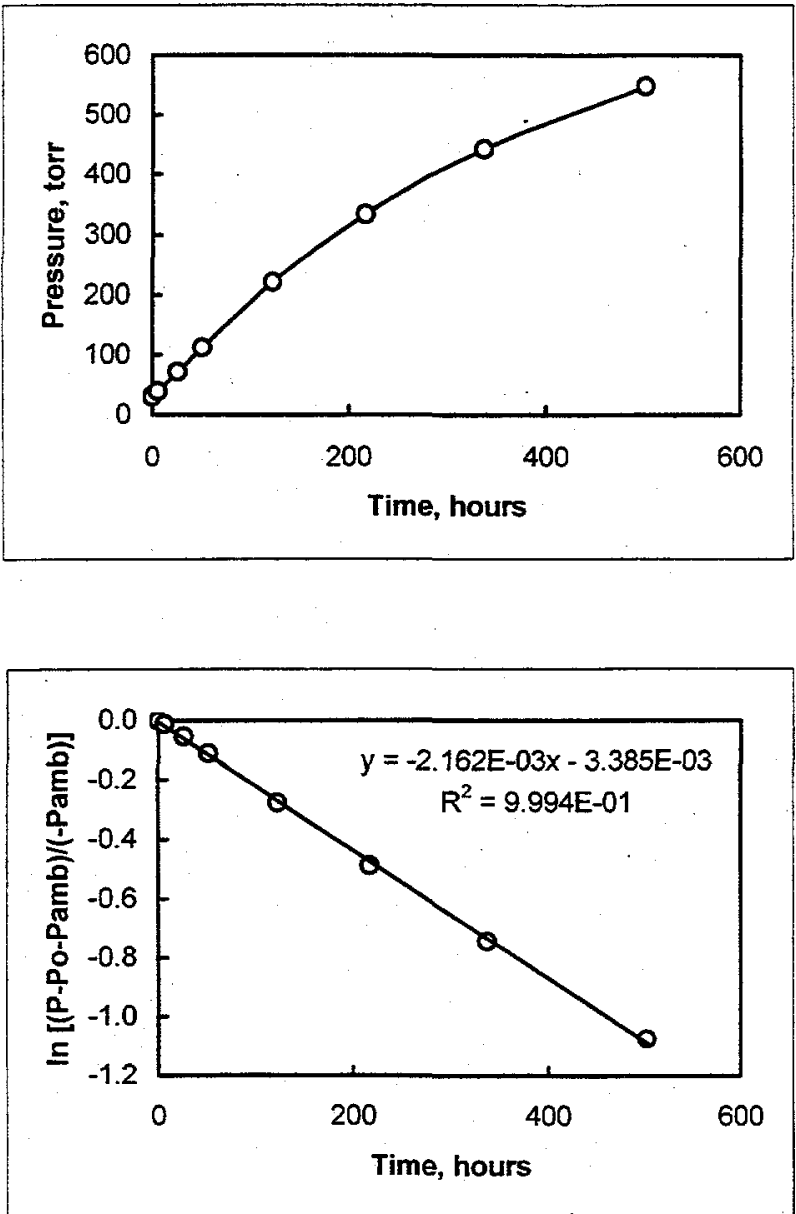
Film:

Panel:

Gas:

E 92744-89-1

A-II-3

Helium

Internal Volume: $\quad 15.00 \mathrm{~cm}^{3}$

$\begin{array}{rrrr}\text { Date } & \text { Time } & \text { Hours } & P \text {, torr } \\ 1 / 17 / 96 & 11: 00 \mathrm{AM} & 0 & 13.5 \\ 1 / 17 / 96 & 5: 00 \mathrm{PM} & 6 & 18.9 \\ 1 / 18 / 96 & 1: 45 \mathrm{PM} & 26 & 42.9 \\ 1 / 19 / 96 & 3: 30 \mathrm{PM} & 51 & 69.4 \\ 1 / 22 / 96 & 4: 15 \mathrm{PM} & 123 & 144.5 \\ 1 / 26 / 96 & 3: 00 \mathrm{PM} & 217 & 227.3 \\ 1 / 31 / 96 & 4: 10 \mathrm{PM} & 337.4 & 316.9 \\ 2 / 7 / 96 & 1: 30 \mathrm{PM} & 502.7 & 416.7 \\ 2 / 16 / 96 & 8: 45 \mathrm{AM} & 713.2 & 522.5\end{array}$
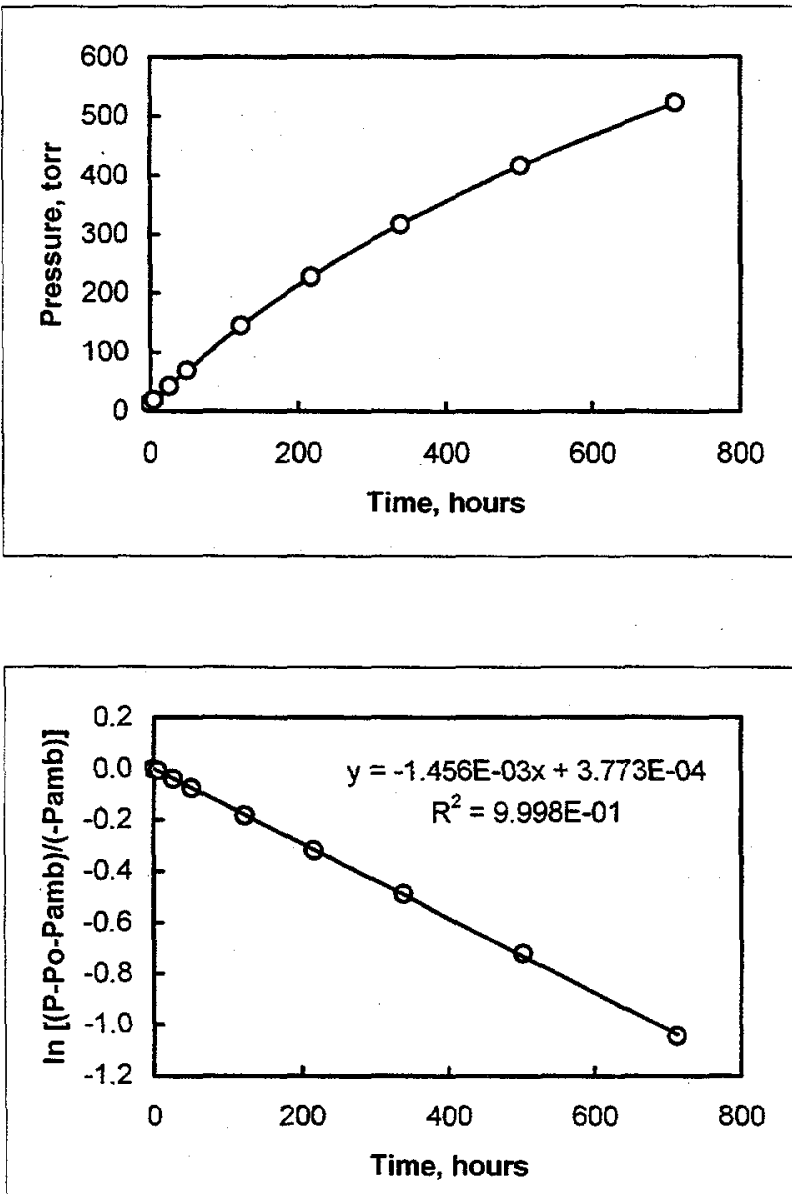
Film:

E $92744-89-1$

Panel Set:

A-II

Gas:

Helium

$P=P o+P a m b[1-\exp (-b t)]$

\begin{tabular}{lrrrrr} 
Panel & V, cc & A, in. ${ }^{2}$ & $b$ & \multicolumn{2}{c}{ Alb Permeance } \\
A-II-1 & 0.00 & 367.5 & - & - & - \\
A-ll-2 & 7.66 & 370.0 & $2.162 E-03$ & $1.711 E+05$ & 0.21 \\
A-II-3 & 15.00 & 359.0 & $1.456 E-03$ & $2.466 E+05$ & 0.21
\end{tabular}

Permeance units $=c c(S T P) / 100$ in. $^{2} \cdot$ atm $\cdot$ day

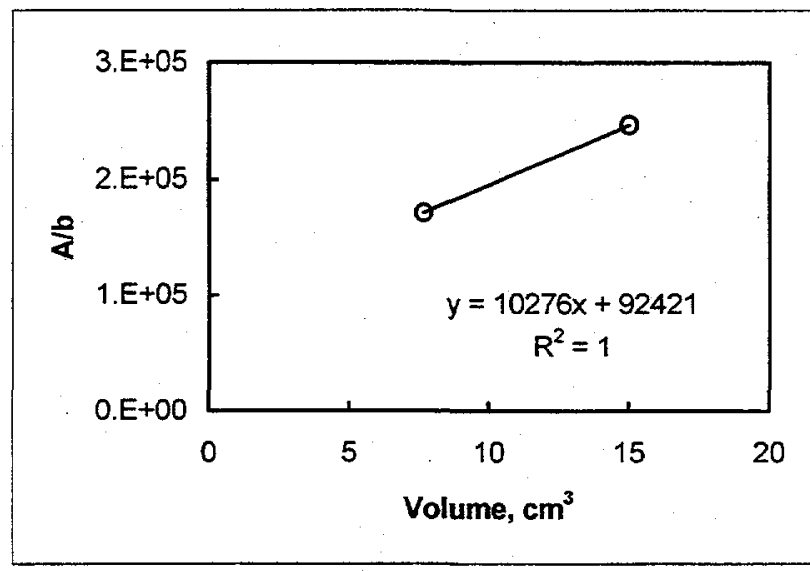

$V_{0}=\quad 9.0 \mathrm{~cm}^{3}$ 
Film:

E 92744-89-1

Panel:

A-III-1

Gas:

Air

Internal Volume:

$0 \mathrm{~cm}^{3}$

$\begin{array}{rrrr}\text { Date } & \text { Time } & \text { Hours } & \text { P, torr } \\ \text { 9/21/95 } & 6: 20 \mathrm{PM} & 0 & 6.2 \\ 10 / 5 / 95 & 5: 15 \mathrm{PM} & 334.9 & 6.2 \\ 11 / 11 / 95 & 4: 35 \mathrm{PM} & 1222.23 & 10.4 \\ 1 / 17 / 96 & 7: 30 \mathrm{AM} & 2821.1 & 15.9 \\ 2 / 1 / 96 & 9: 30 \mathrm{AM} & 3183.1 & 16.7 \\ 2 / 21 / 96 & 12: 00 \mathrm{PM} & 3665.6 & 18.9 \\ 3 / 26 / 96 & 2: 50 \mathrm{PM} & 4484.1 & 22.2 \\ 4 / 25 / 96 & 8: 30 \mathrm{AM} & 5198.1 & 24.5 \\ 5 / 31 / 96 & 10: 45 \mathrm{AM} & 6064.4 & 27.8\end{array}$

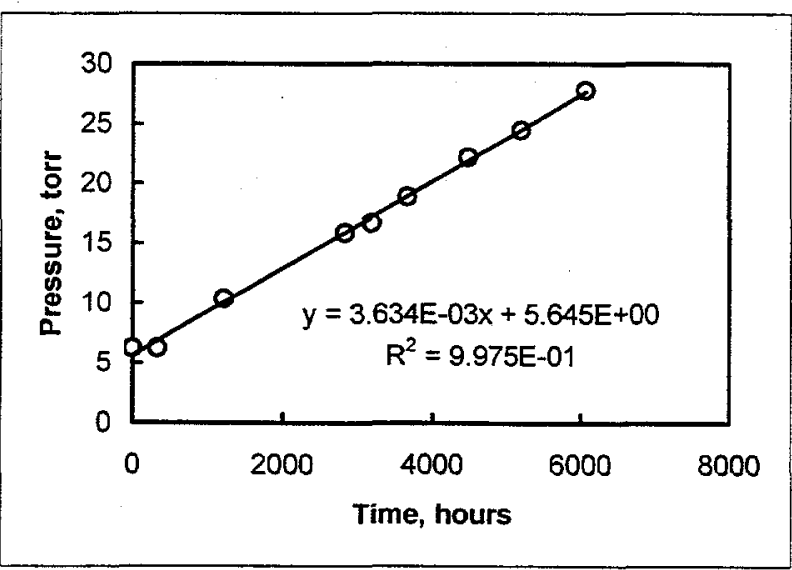


Film:

Panel:

Gas:

E 92744-89-1

Internal Volume:

A-III-2

Air

$7.43 \mathrm{~cm}^{3}$

$\begin{array}{rrrr}\text { Date } & \text { Time } & \text { Hours } & P, \text { torr } \\ 9 / 20 / 95 & 6: 30 \mathrm{PM} & 0 & 5.2 \\ 10 / 5 / 95 & 5: 15 \mathrm{PM} & 358.75 & 7.3 \\ 11 / 11 / 95 & 4: 35 \mathrm{PM} & 1246.08 & 7.8 \\ 1 / 17 / 96 & 7: 30 \mathrm{AM} & 2845 & 8.5 \\ 2 / 1 / 96 & 9: 30 \mathrm{AM} & 3207 & 10.1 \\ 2 / 21 / 96 & 12: 00 \mathrm{PM} & 3689.5 & 10.7 \\ 3 / 26 / 96 & 2: 50 \mathrm{PM} & 4508.3 & 12.6 \\ 4 / 25 / 96 & 8: 30 \mathrm{AM} & 5222 & 13.0 \\ 5 / 31 / 96 & 10: 45 \mathrm{AM} & 6088.2 & 14.5\end{array}$

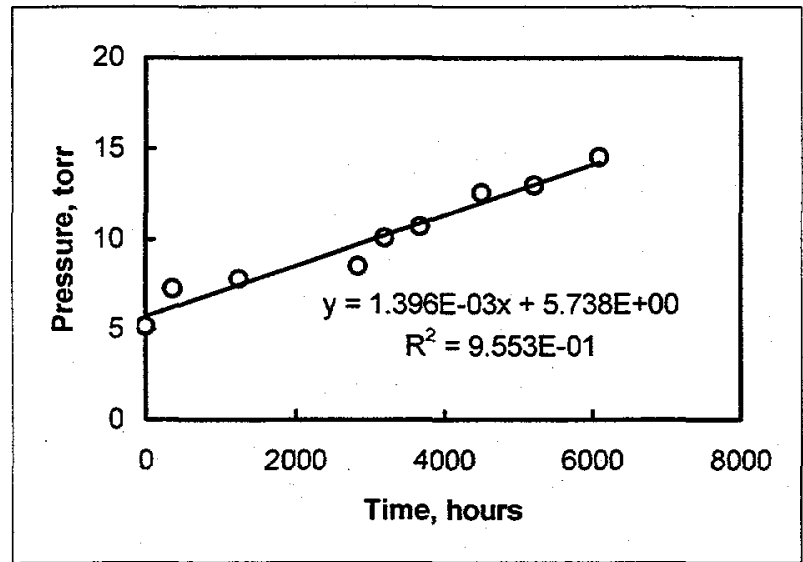


Film:

Panel:

E 92744-89-1

Gas:

A-111-3

Internal Volume:

Air

$15.27 \mathrm{~cm}^{3}$

$\begin{array}{rrrr}\text { Date } & \text { Time } & \text { Hours } & \text { P, torr } \\ 8 / 11 / 95 & 3: 00 \mathrm{PM} & 0 & 5.2 \\ 8 / 25 / 95 & 7: 00 \mathrm{AM} & 304 & 5.2 \\ 9 / 8 / 95 & 6: 30 \mathrm{AM} & 639.5 & 9.3 \\ 9 / 20 / 95 & 4: 30 \mathrm{PM} & 937.5 & 11.5 \\ 10 / 5 / 95 & 5: 15 \mathrm{PM} & 1298.25 & 10.7 \\ 11 / 11 / 95 & 4: 35 \mathrm{PM} & 2185.58 & 9.4 \\ 1 / 17 / 96 & 7: 30 \mathrm{AM} & 3784.5 & 13.4 \\ 2 / 1 / 96 & 9: 30 \mathrm{AM} & 4146.5 & 10.4 \\ 2 / 21 / 96 & 12: 00 \mathrm{PM} & 4647 & 15.6 \\ 3 / 26 / 96 & 2: 50 \mathrm{PM} & 5465.8 & 10.4 \\ 4 / 25 / 96 & 8: 30 \mathrm{AM} & 6179.5 & 11.2 \\ 5 / 31 / 96 & 10: 45 \mathrm{AM} & 7045.8 & 14.7\end{array}$

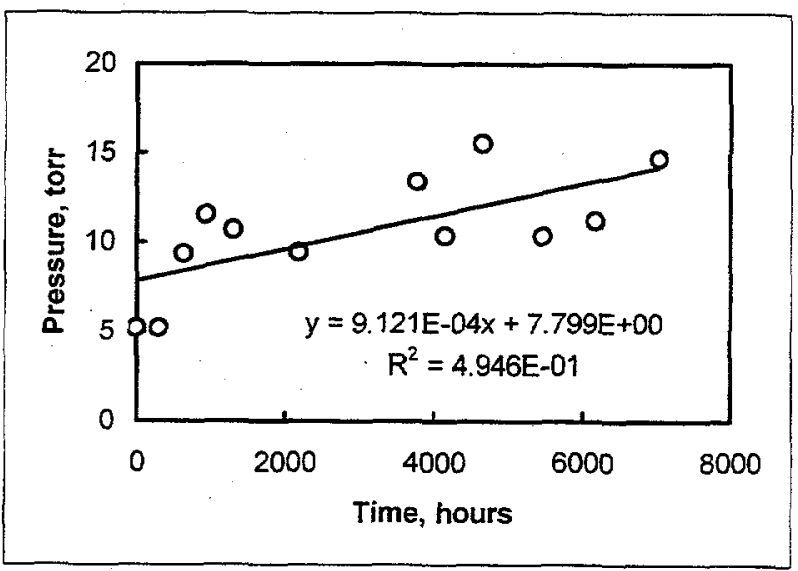


Film:

Panel Set:

E 92744-89-1

Gas:

A-III

Air

$P=a+b t$

Panel

$\mathrm{V}, \mathrm{cc}$

$A$, in. $^{2}$

a

b $A^{\star}($ Pamb-a)/b Permeance

A-III-1

196.0

5.645 3.634E-03

4.203E+07 0.00027

A-III-2

7.43

196.0

5.738 1.396E-03

$1.094 E+08 \quad 0.00025$

A-III-3

15.27

198.4

$7.7999 .121 \mathrm{E}-04$

$1.691 E+08 \quad 0.00026$

Permeance units $=c c(S T P) / 100$ in. $^{2} \cdot$ atm•day

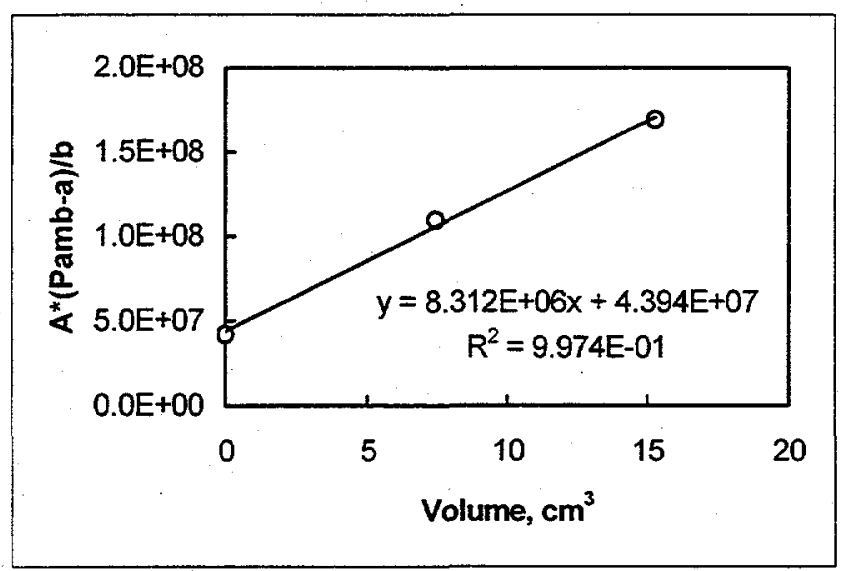

$V_{0}=$

$5.3 \mathrm{~cm}^{3}$ 
Film:

Panel:

Gas:

E 92744-89-1

A-III-1

Helium

Internal Volume: $\quad 0 \mathrm{~cm}^{3}$

$\begin{array}{rrrr}\text { Date } & \text { Time } & \text { Hours } & \text { P. torr } \\ 5 / 31 / 96 & 11: 30 \mathrm{AM} & 0 & 27.8 \\ 6 / 1 / 96 & 2: 30 \mathrm{PM} & 27 & 86.1 \\ 6 / 2 / 96 & 12: 00 \mathrm{PM} & 48 & 129.2 \\ 6 / 4 / 96 & 12: 30 \mathrm{PM} & 96 & 215.3 \\ 6 / 6 / 96 & 1: 00 \mathrm{PM} & 144 & 291.6 \\ 6 / 10 / 96 & 1: 30 \mathrm{PM} & 240 & 423.6 \\ 6 / 14 / 96 & 2: 00 \mathrm{PM} & 336 & 500.4\end{array}$
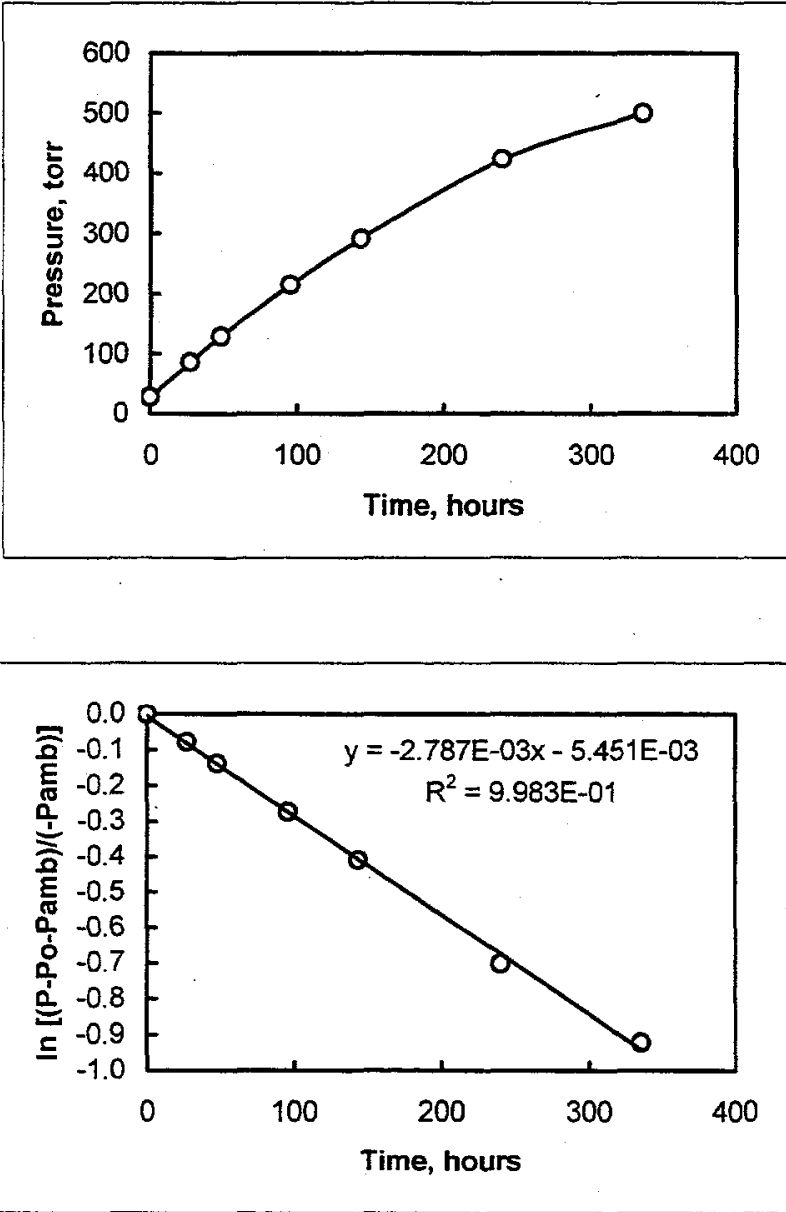
Film:

Panel:

E 92744-89-1

Gas:

A-III-2

Internal Volume: $\quad 7.43 \mathrm{~cm}^{3}$

$\begin{array}{rrrr}\text { Date } & \text { Time } & \text { Hours } & \text { P, torr } \\ 5 / 31 / 96 & 11: 30 \mathrm{AM} & 0 & 14.5 \\ 6 / 1 / 96 & 2: 30 \mathrm{PM} & 27 & 40.6 \\ 6 / 2 / 96 & 12: 00 \mathrm{PM} & 48 & 61.2 \\ 6 / 4 / 96 & 12: 30 \mathrm{PM} & 96 & 105.3 \\ 6 / 6 / 96 & 1: 00 \mathrm{PM} & 144 & 144.1 \\ 6 / 10 / 96 & 1: 30 \mathrm{PM} & 240 & 223.1 \\ 6 / 14 / 96 & 2: 00 \mathrm{PM} & 336 & 286.3 \\ 6 / 26 / 96 & 10: 00 \mathrm{AM} & 619.5 & 431.2\end{array}$
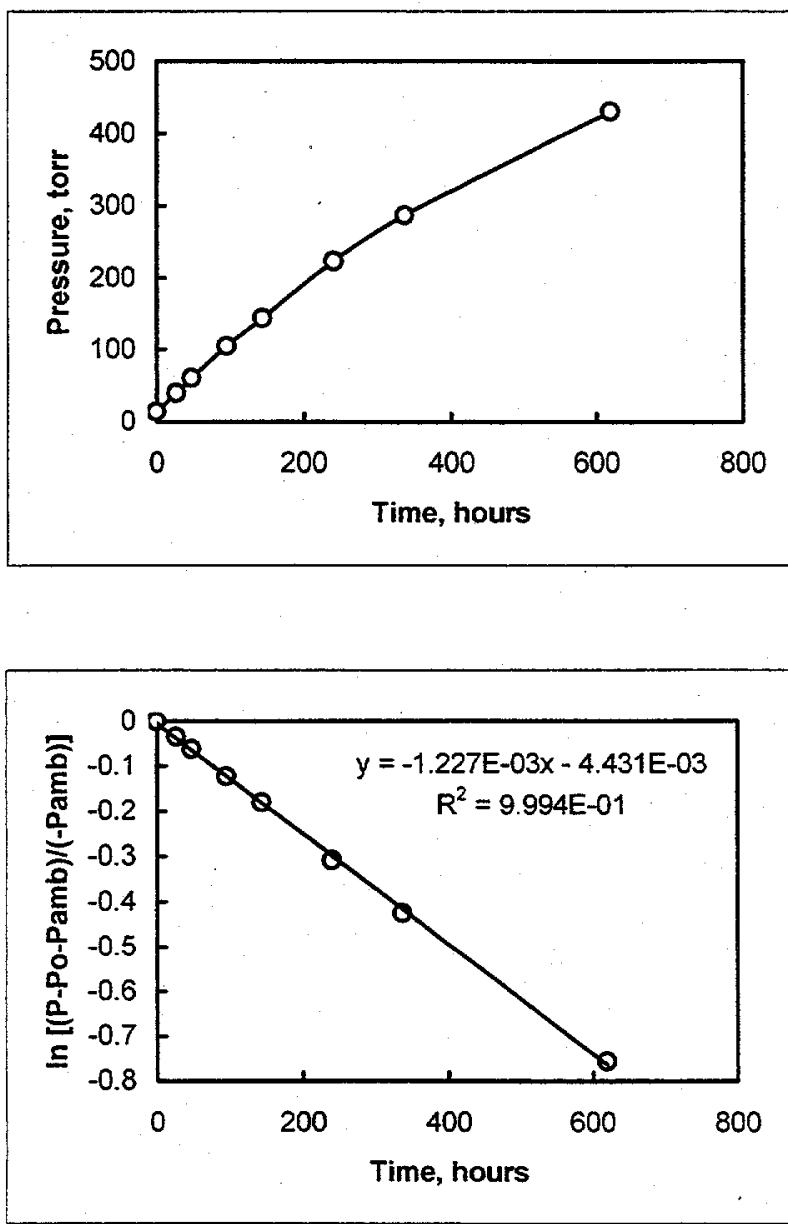
Film:

Panel:

E 92744-89-1

Gas:

A-III-3

Internal Volume:

Helium

$15.27 \mathrm{~cm}^{3}$

$\begin{array}{rrrr}\text { Date } & \text { Time } & \text { Hours } & P \text {, torr } \\ 5 / 31 / 96 & 11: 30 \mathrm{AM} & 0 & 14.7 \\ 6 / 1 / 96 & 2: 30 \mathrm{PM} & 27 & 28.8 \\ 6 / 2 / 96 & 12: 00 \mathrm{PM} & 48 & 41.7 \\ 6 / 4 / 96 & 12: 30 \mathrm{PM} & 96 & 69.7 \\ 6 / 6 / 96 & 1: 00 \mathrm{PM} & 144 & 97.4 \\ 6 / 10 / 96 & 1: 30 \mathrm{PM} & 240 & 150.6 \\ 6 / 14 / 96 & 2: 00 \mathrm{PM} & 336 & 196.8 \\ 6 / 26 / 96 & 10: 00 \mathrm{AM} & 619.5 & 311.7 \\ 7 / 8 / 96 & 11: 15 \mathrm{AM} & 908.8 & 423.9\end{array}$
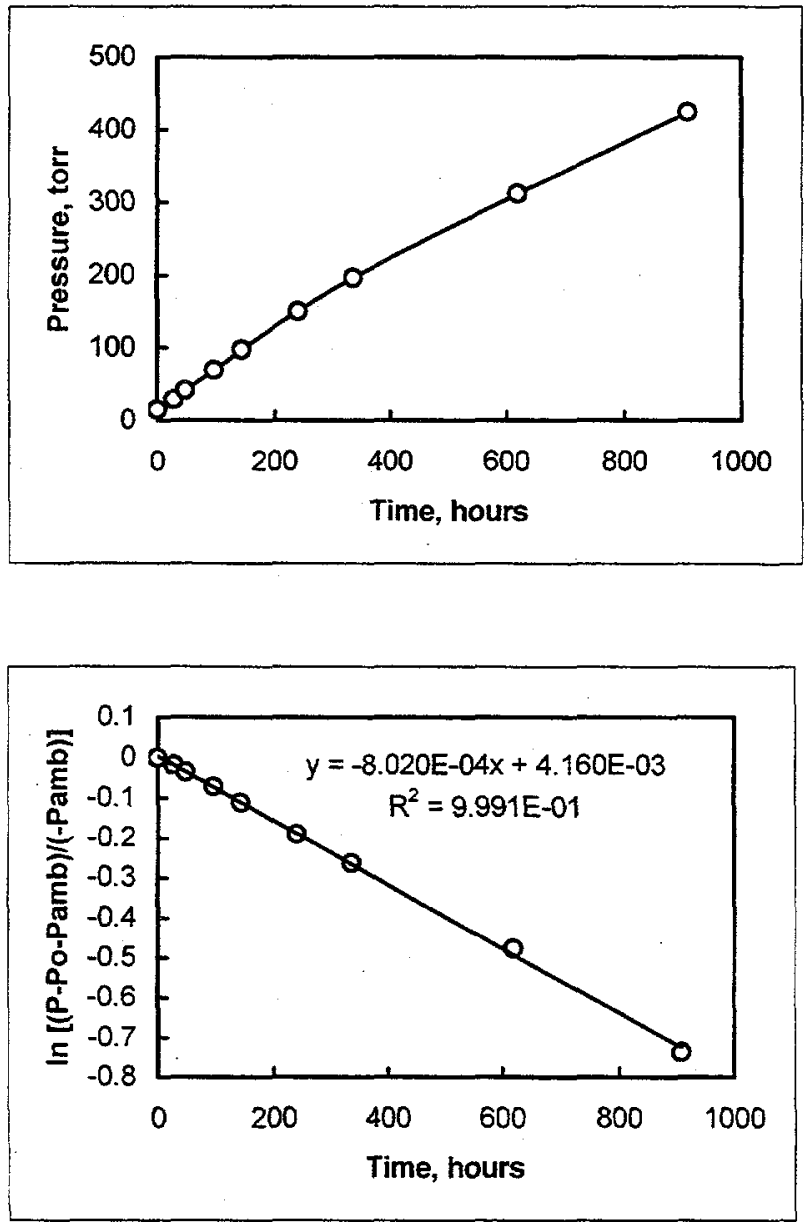
Film:

Panel Set:

E 92744-89-1

Gas:

A-III

Helium

$P=P o+P a m b[1-\exp (-b t)]$

Panel $\quad V, c c \quad A$, in. $^{2} \quad b \quad A / b$ Permeance

$\begin{array}{llllll}\text { A-III-1 } & 0.00 & 196.0 & 2.787 \mathrm{E}-03 & 7.033 \mathrm{E}+04 & 0.19\end{array}$

$\begin{array}{llllll}\text { A-III-2 } & 7.43 & 196.0 & 1.227 \mathrm{E}-03 & 1.597 \mathrm{E}+05 & 0.18\end{array}$

$\begin{array}{llllll}\text { A-III-3 } & 15.27 & 198.4 & 8.020 \mathrm{E}-04 & 2.474 \mathrm{E}+05 & 0.19\end{array}$

Permeance units $=c c(S T P) / 100$ in. $^{2} \cdot a t m \cdot d a y$

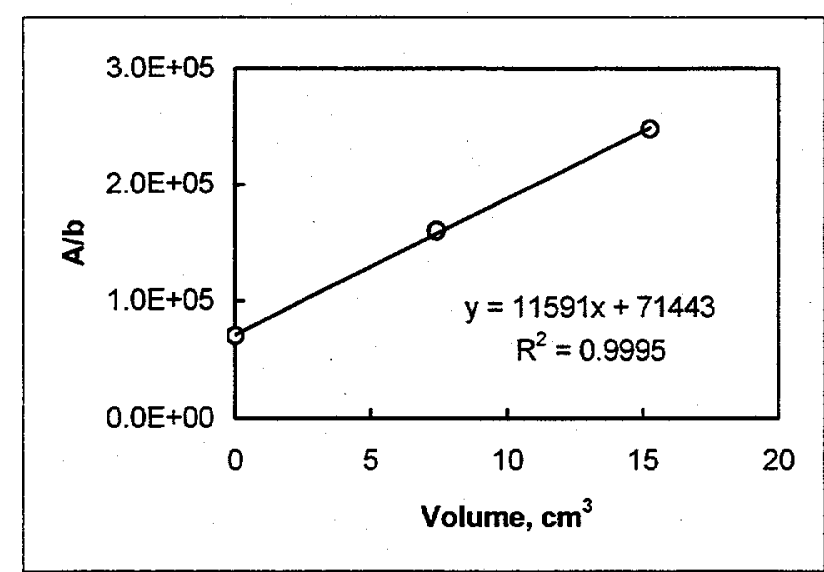
$V_{0}=$
$6.2 \mathrm{~cm}^{3}$ 
Film:

Panel:

E 92744-89-2 with Surlyn

Gas:

B-I-1

Internal Volume: $\quad 0 \mathrm{~cm}^{3}$

$\begin{array}{rrrr}\text { Date } & \text { Time } & \text { Hours } & P \text {, torr } \\ \text { 1/6/95 } & 11: 00 \mathrm{AM} & 0 & 9.3 \\ 1 / 13 / 95 & 11: 00 \mathrm{AM} & 168 & 14.5 \\ 1 / 20 / 95 & 11: 00 \mathrm{AM} & 336 & 16.1 \\ 1 / 27 / 95 & 11: 00 \mathrm{AM} & 503 & 18.8 \\ 2 / 3 / 95 & 9: 30 \mathrm{AM} & 670.5 & 19.1 \\ 2 / 10 / 95 & 9: 00 \mathrm{AM} & 838 & 23.1 \\ 2 / 24 / 95 & 9: 00 \mathrm{AM} & 1174 & 26.5 \\ 3 / 10 / 95 & 9: 00 \mathrm{AM} & 1510 & 31.2 \\ 3 / 24 / 95 & 9: 00 \mathrm{AM} & 1846 & 36.0 \\ 4 / 12 / 95 & 9: 00 \mathrm{AM} & 2302 & 42.1 \\ 5 / 11 / 95 & 9: 00 \mathrm{AM} & 2998 & 49.1 \\ 6 / 8 / 95 & 9: 00 \mathrm{AM} & 3670 & 57.8\end{array}$

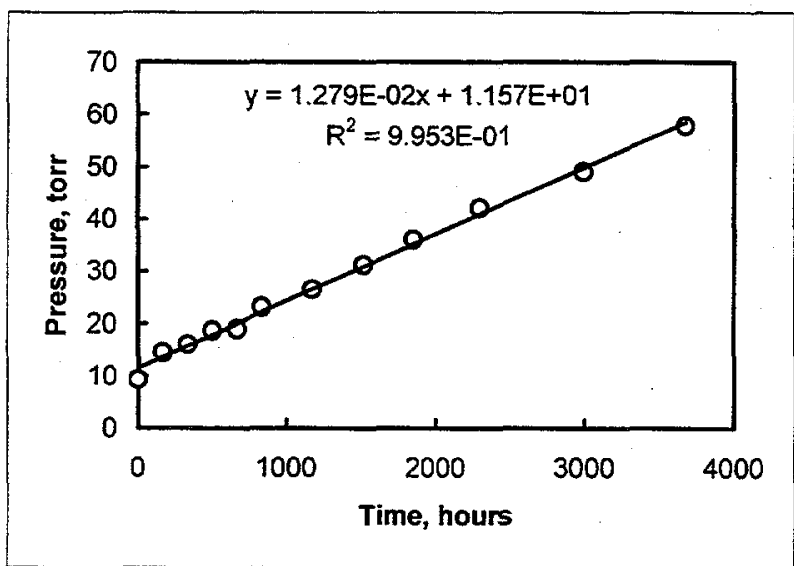


Film:

Panel:

E 92744-89-2 with Surlyn

Gas:

B-l-2

Internal Volume: $\quad 7.693 \mathrm{~cm}^{3}$

$\begin{array}{rrrr}\text { Date } & \text { Time } & \text { Hours } & \text { P, torr } \\ 1 / 6 / 95 & 11: 00 \mathrm{AM} & 0 & 4.7 \\ 1 / 13 / 95 & 11: 00 \mathrm{AM} & 168 & 6.2 \\ 1 / 20 / 95 & 11: 00 \mathrm{AM} & 336 & 8.8 \\ 1 / 27 / 95 & 11: 00 \mathrm{AM} & 503 & 10.9 \\ 2 / 3 / 95 & 9: 30 \mathrm{AM} & 670.5 & 13.0 \\ 2 / 10 / 95 & 9: 00 \mathrm{AM} & 838 & 14.3 \\ 2 / 24 / 95 & 9: 00 \mathrm{AM} & 1174 & 17.7 \\ 3 / 10 / 95 & 9: 00 \mathrm{AM} & 1510 & 21.6 \\ 3 / 24 / 95 & 9: 00 \mathrm{AM} & 1846 & 25.9 \\ 4 / 12 / 95 & 9: 00 \mathrm{AM} & 2302 & 31.0 \\ 5 / 11 / 95 & 9: 00 \mathrm{AM} & 2998 & 38.5 \\ 6 / 8 / 95 & 9: 00 \mathrm{AM} & 3670 & 45.5\end{array}$

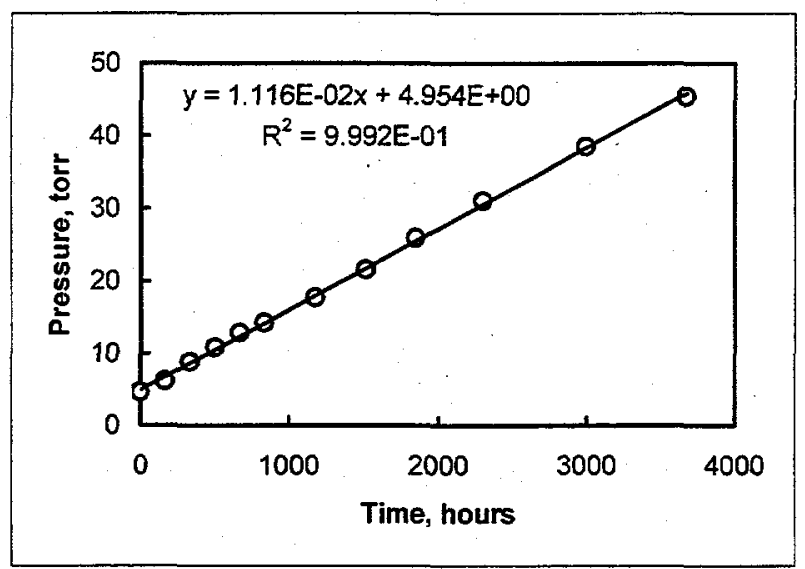


Film:

Panel:

Gas:

Internal Volume:
E 92744-89-2 with Surlyn

B-1-3

Air

$14.757 \mathrm{~cm}^{3}$

$\begin{array}{rrrr}\text { Date } & \text { Time } & \text { Hours } & P \text {, torr } \\ 1 / 6 / 95 & 11: 00 \mathrm{AM} & 0 & 4.2 \\ 1 / 13 / 95 & 11: 00 \mathrm{AM} & 168 & 4.7 \\ 1 / 20 / 95 & 11: 00 \mathrm{AM} & 336 & 5.7 \\ 1 / 27 / 95 & 11: 00 \mathrm{AM} & 503 & 6.7 \\ 2 / 3 / 95 & 9: 30 \mathrm{AM} & 670.5 & 7.8 \\ 2 / 10 / 95 & 9: 00 \mathrm{AM} & 838 & 8.9 \\ 2 / 24 / 95 & 9: 00 \mathrm{AM} & 1174 & 9.3 \\ 3 / 10 / 95 & 9: 00 \mathrm{AM} & 1510 & 10.5 \\ 3 / 24 / 95 & 9: 00 \mathrm{AM} & 1846 & 12.8 \\ 4 / 12 / 95 & 9: 00 \mathrm{AM} & 2302 & 13.8 \\ 5 / 11 / 95 & 9: 00 \mathrm{AM} & 2998 & 18.4 \\ 6 / 8 / 95 & 9: 00 \mathrm{AM} & 3670 & 20.8\end{array}$

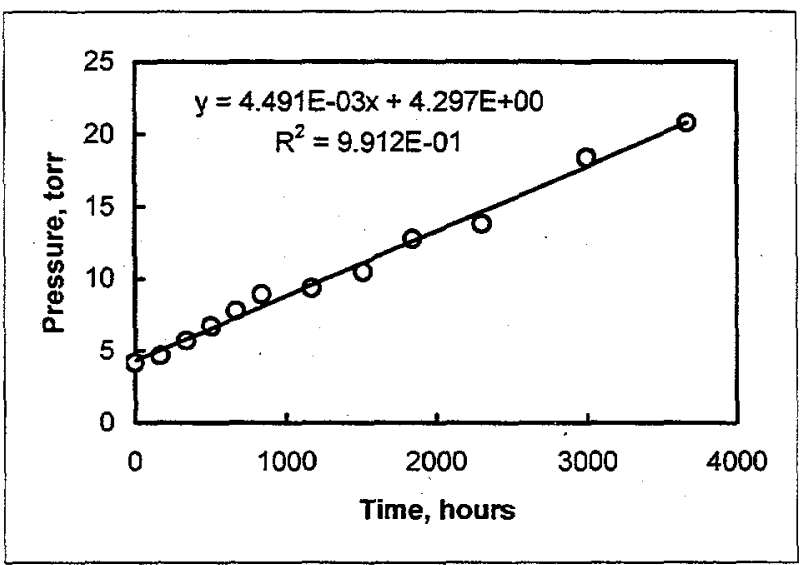


Film:

Panel Set:

E 92744-89-2 with Surlyn

Gas:

Air

$P=a+b t$

\begin{tabular}{|c|c|c|c|c|c|c|}
\hline Panel & $V, c c$ & $A_{1}$ in. $^{2}$ & a & $b$ & $A^{*}($ Pamb-a)/b & Permeance \\
\hline$B-I-1$ & 0 & 169 & 11.57 & 1.279E-02 & $1.022 E+07$ & 0.0012 \\
\hline$B-1-2$ & 7.693 & 169 & 4.954 & 1.116E-02 & 1.181E+07 & 0.0025 \\
\hline$B-1-3$ & 14.757 & 169 & 4.297 & 4.491E-03 & $2.938 \mathrm{E}+07$ & 0.0015 \\
\hline
\end{tabular}

Permeance units $=c c($ STP $) / 100$ in. ${ }^{2} \cdot$ atm•day

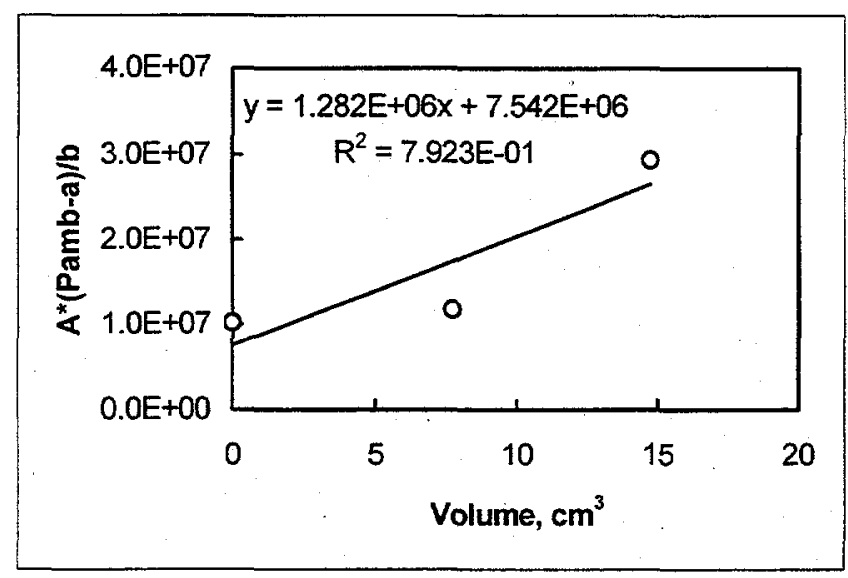

$V_{0}=\quad 5.9 \mathrm{~cm}^{3}$ 
Film:

Panel:

Gas:

Internal Volume:
E 92744-89-2 with Surlyn

B-I-3

Helium

$14.757 \mathrm{~cm}^{3}$

$\begin{array}{rrrr}\text { Date } & \text { Time } & \text { Hours } & \text { P, torr } \\ 6 / 8 / 95 & 10: 45 \mathrm{AM} & 0 & 20.8 \\ 6 / 8 / 95 & 4: 45 \mathrm{PM} & 6 & 25.4 \\ 6 / 9 / 95 & 4: 45 \mathrm{PM} & 29.25 & 41.5 \\ 6 / 14 / 95 & 10: 20 \mathrm{AM} & 112.9 & 109.8 \\ 7 / 17 / 95 & 3: 15 \mathrm{PM} & 909.5 & 440.0 \\ 8 / 18 / 95 & 3: 20 \mathrm{PM} & 1676.6 & 615.6\end{array}$
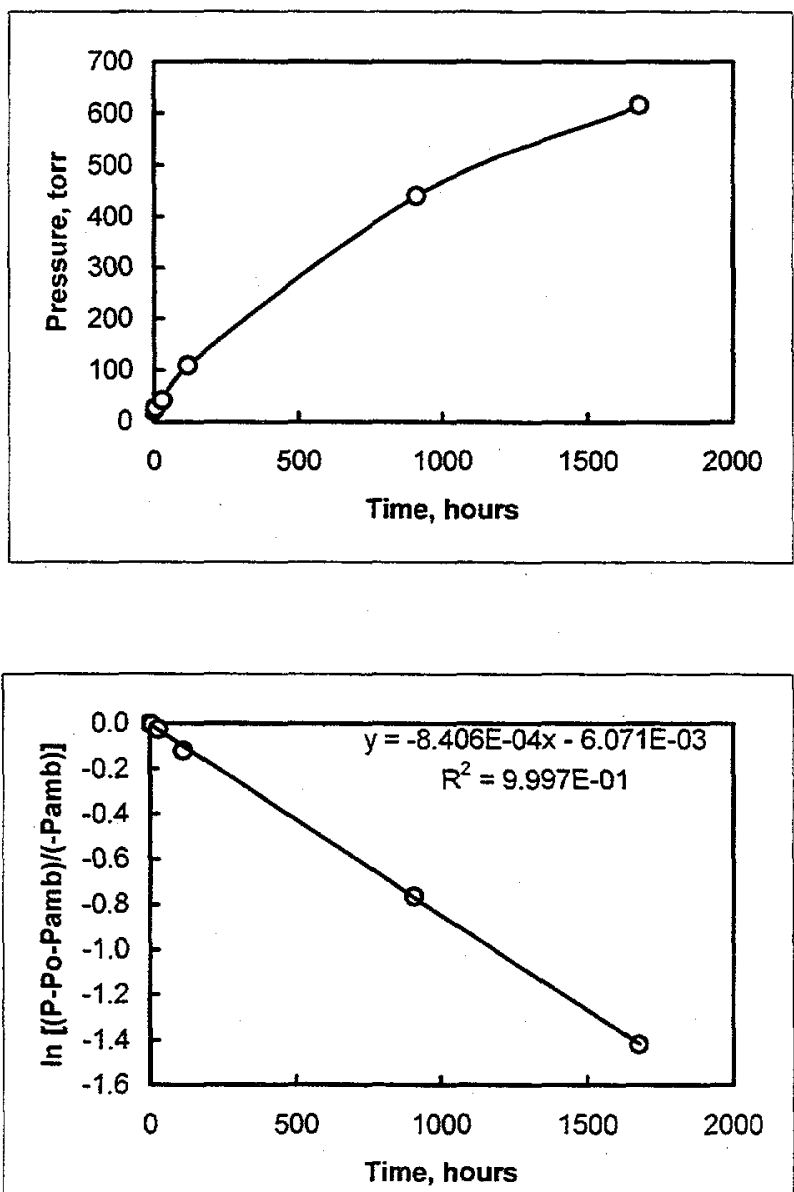
Film:

E 92744-89-2 with Surlyn

Panel Set:

B-I

Gas:

Helium

$P=P o+P a m b[1-\exp (-b t)]$

$\begin{array}{lrrrr}\text { Panel } & \text { V, cc } & \text { A, in. }{ }^{2} & \text { b Permeance } \\ \text { B-I-3 } & 14.757 & 169 & 8.406 \text { E-04 } & 0.22\end{array}$

Permeance units $=c c($ STP $) / 100$ in. $^{2} \cdot$ atm $\cdot$ day

Vo assumed to be $5.9 \mathrm{~cm}^{3}$ as for runs in air. 
Film:

E 92744-89-2 with Surlyn

Panel:

B-II-1

Gas:

Air

Internal Volume: $\quad 0 \mathrm{~cm}^{3}$

$\begin{array}{rrrr}\text { Date } & \text { Time } & \text { Hours } & P \text {, torr } \\ 2 / 1 / 96 & 9: 30 \mathrm{AM} & 0 & 6.2 \\ 2 / 21 / 96 & 12: 00 \mathrm{PM} & 482.5 & 10.4 \\ 3 / 26 / 96 & 2: 50 \mathrm{PM} & 1301.3 & 15.8 \\ 4 / 25 / 96 & 8: 30 \mathrm{AM} & 2015 & 19.4 \\ 5 / 31 / 96 & 10: 45 \mathrm{AM} & 2881.2 & 26.8 \\ 6 / 27 / 96 & 8: 30 \mathrm{AM} & 3527 & 31.0 \\ 7 / 31 / 96 & 12: 00 \mathrm{PM} & 4346.5 & 36.7\end{array}$

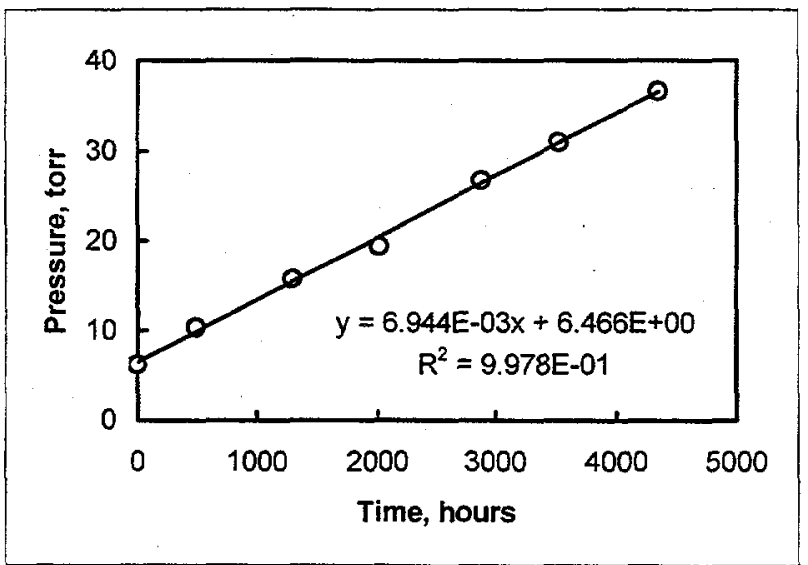


Film:

Panel:

E 92744-89-2 with Surlyn

Gas:

B-II-2

Internal Volume: $\quad 7.43 \mathrm{~cm}^{3}$

$\begin{array}{rrrr}\text { Date } & \text { Time } & \text { Hours } & \text { P, torr } \\ 2 / 1 / 96 & 9: 30 \mathrm{AM} & 0 & 4.7 \\ 2 / 21 / 96 & 12: 00 \mathrm{PM} & 482.5 & 5.7 \\ 3 / 26 / 96 & 2: 50 \mathrm{PM} & 1301.3 & 8.9 \\ 4 / 25 / 96 & 8: 30 \mathrm{AM} & 2015 & 10.4 \\ 5 / 31 / 96 & 10: 45 \mathrm{AM} & 2881.2 & 14.1 \\ 6 / 27 / 96 & 8: 30 \mathrm{AM} & 3527 & 16.9 \\ 7 / 31 / 96 & 12: 00 \mathrm{PM} & 4346.5 & 18.9\end{array}$

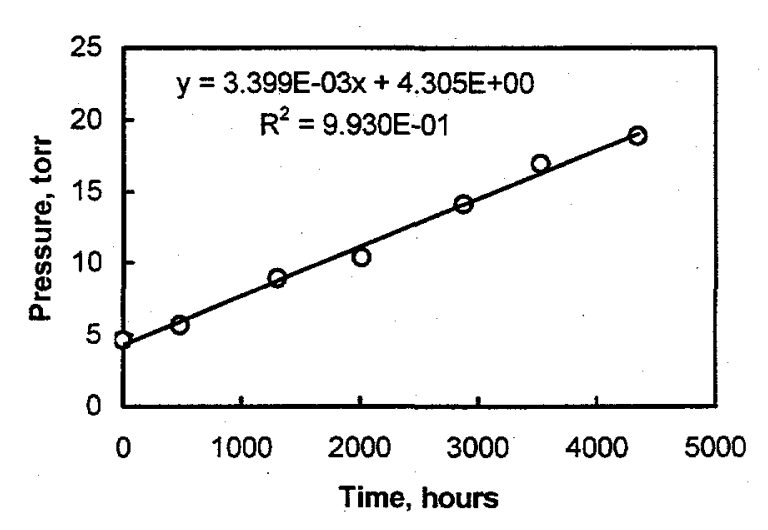


Film:

Panel:

Gas:

E 92744-89-2 with Surlyn

B-II-3

Internal Volume: $\quad 15.27 \mathrm{~cm}^{3}$

$\begin{array}{rrrr}\text { Date } & \text { Time } & \text { Hours } & P \text {, torr } \\ 2 / 1 / 96 & 9: 30 \mathrm{AM} & 0 & 4.7 \\ 2 / 21 / 96 & 12: 00 \mathrm{PM} & 482.5 & 5.7 \\ 3 / 26 / 96 & 2: 50 \mathrm{PM} & 1301: 3 & 6.5 \\ 4 / 25 / 96 & 8: 30 \mathrm{AM} & 2015 & 7.3 \\ 5 / 31 / 96 & 10: 45 \mathrm{AM} & 2881.2 & 9.9 \\ 6 / 27 / 96 & 8: 30 \mathrm{AM} & 3527 & 10.5 \\ 7 / 31 / 96 & 12: 00 \mathrm{PM} & 4346.5 & 11.4\end{array}$

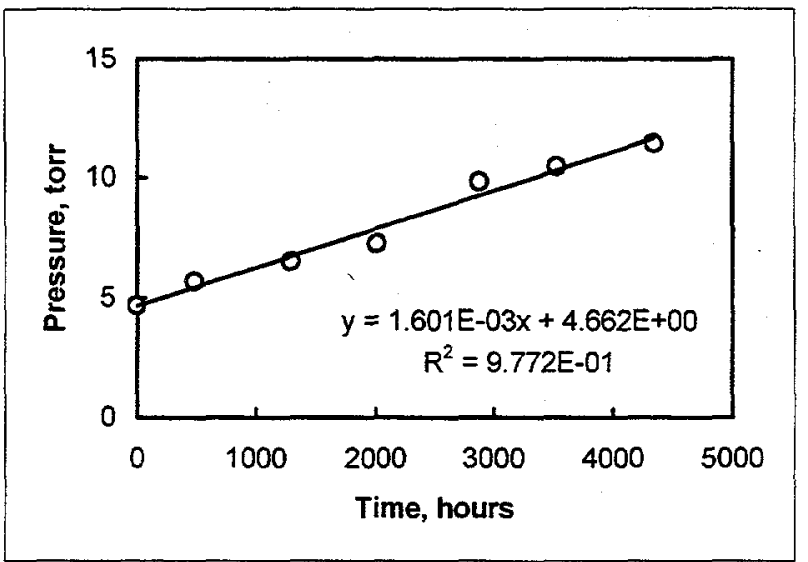


Film:

E 92744-89-2 with Surlyn

Panel Set:

B-II

Gas:

Air

$P=a+b t$

Panel

$\mathrm{V}, \mathrm{cc}$

$A$, in. ${ }^{2}$

$a$

b $A^{*}($ Pamb-a)/b Permeance

B-II-1

197

6.466 6.944E-03

$2.209 E+07 \quad 0.00034$

B-II-2

7.43

196

4.305 3.399E-03

$4.502 E+07 \quad 0.00052$

B-II-3

15.27

199

4.662 1.601E-03

$9.699 \mathrm{E}+07 \quad 0.00042$

Permeance units $=c c($ STP $) / 100$ in. $^{2} \cdot$ atm $\cdot$ day

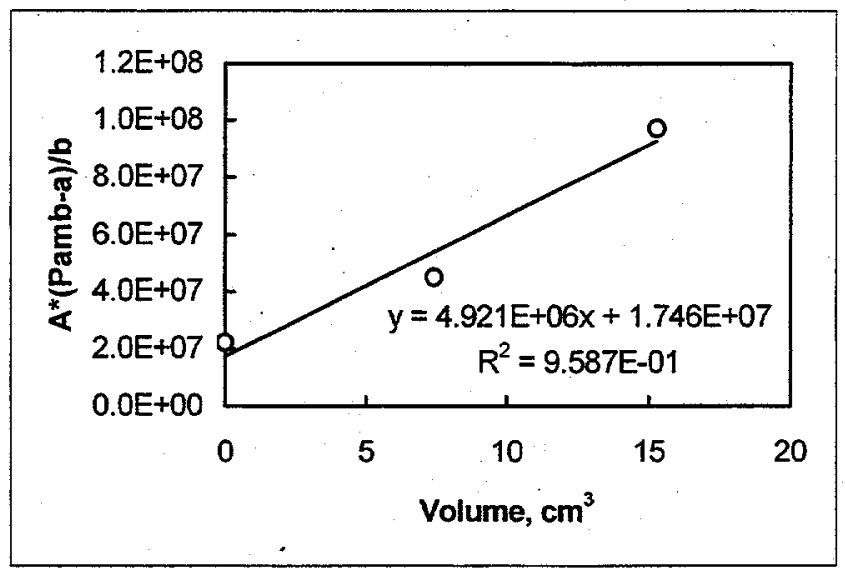

$V_{0}=$

$3.5 \mathrm{~cm}^{3}$ 
Film:

Panel:

Gas:

E 92744-89-2 with Surlyn

Internal Volume:

B-II-1

Helium

$0 \mathrm{~cm}^{3}$

$\begin{array}{rrrr}\text { Date } & \text { Time } & \text { Hours } & \text { P, torr } \\ 7 / 31 / 96 & 12: 45 \mathrm{PM} & 0 & 36.7 \\ 8 / 1 / 96 & 2: 00 \mathrm{PM} & 25.25 & 78.4 \\ 8 / 2 / 96 & 2: 20 \mathrm{PM} & 48.8 & 117.9 \\ 8 / 3 / 96 & 4: 10 \mathrm{PM} & 74.1 & 157.7 \\ 8 / 5 / 96 & 1: 30 \mathrm{PM} & 119.1 & 223.1 \\ 8 / 9 / 96 & 12: 30 \mathrm{PM} & 213.4 & 327.3\end{array}$
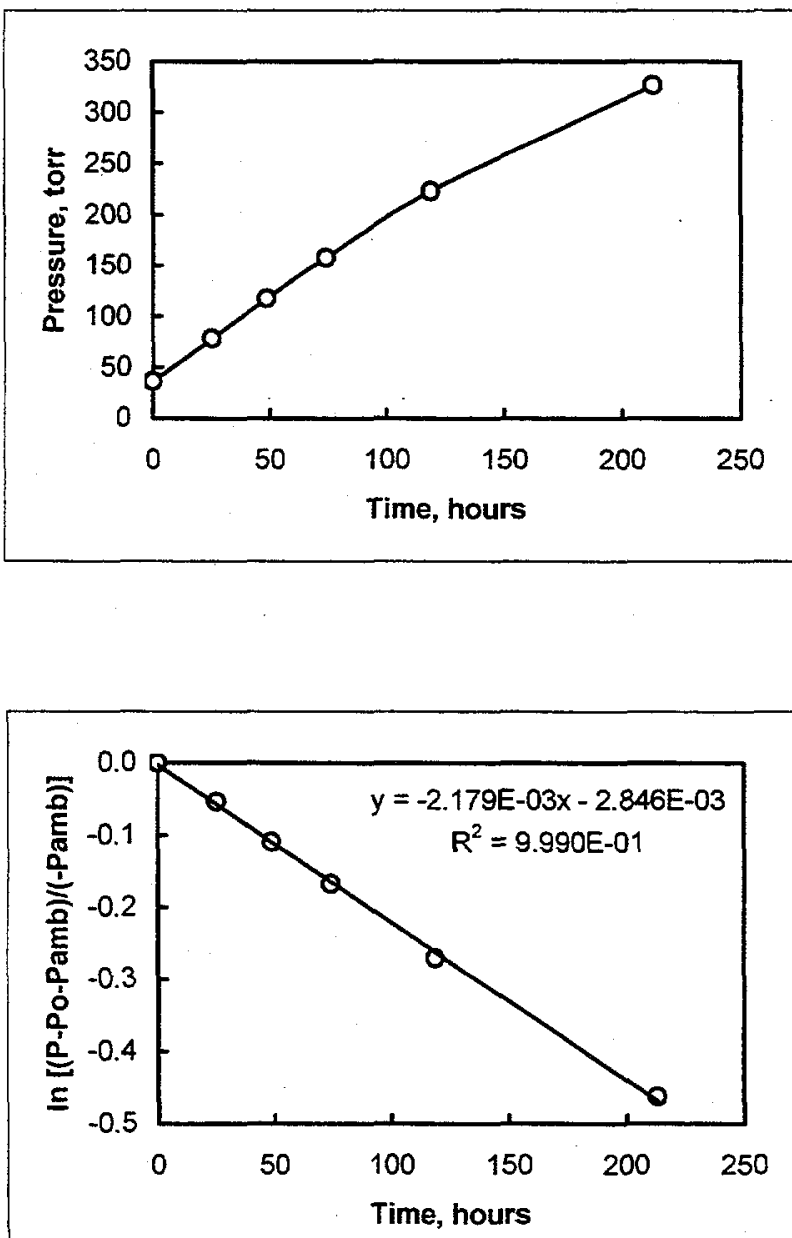
Film:

E 92744-89-2 with Surlyn

Panel:

B-II-2

Gas:

Helium

Internal Volume: $\quad 7.43 \mathrm{~cm}^{3}$

$\begin{array}{rrrr}\text { Date } & \text { Time } & \text { Hours } & \text { P, torr } \\ 7 / 31 / 96 & 12: 45 \mathrm{PM} & 0 & 18.9 \\ 8 / 1 / 96 & 2: 00 \mathrm{PM} & 25.25 & 36.0 \\ 8 / 2 / 96 & 2: 20 \mathrm{PM} & 48.8 & 54.3 \\ 8 / 3 / 96 & 4: 10 \mathrm{PM} & 74.1 & 72.3 \\ 8 / 5 / 96 & 1: 30 \mathrm{PM} & 119.1 & 104.8 \\ 8 / 9 / 96 & 12: 30 \mathrm{PM} & 213.4 & 166.7 \\ 8 / 16 / 96 & 2: 10 \mathrm{PM} & 383.1 & 260.5\end{array}$
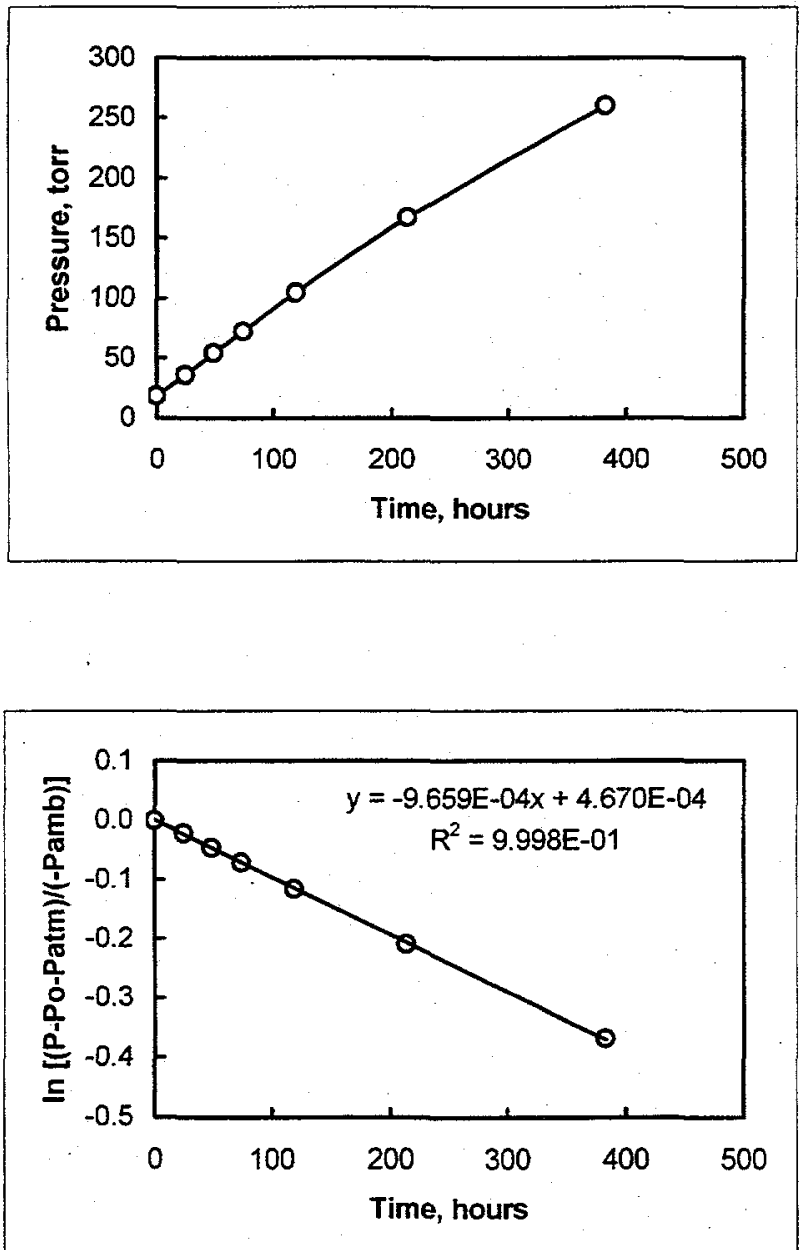
Film:

Panel:

Gas:

E 92744-89-2 with Surlyn

B-II-3

Helium

Internal Volume: $\quad 15.27 \mathrm{~cm}^{3}$

$\begin{array}{rrrr}\text { Date } & \text { Time } & \text { Hours } & P, \text { torr } \\ 7 / 31 / 96 & 12: 45 \mathrm{PM} & 0 & 11.4 \\ 8 / 1 / 96 & 2: 00 \mathrm{PM} & 25.25 & 23.3 \\ 8 / 2 / 96 & 2: 20 \mathrm{PM} & 48.8 & 35.7 \\ 8 / 3 / 96 & 4: 10 \mathrm{PM} & 74.1 & 48.3 \\ 8 / 5 / 96 & 1: 30 \mathrm{PM} & 119.1 & 69.5 \\ 8 / 9 / 96 & 12: 30 \mathrm{PM} & 213.4 & 113.8 \\ 8 / 16 / 96 & 2: 10 \mathrm{PM} & 383.1 & 186.4\end{array}$
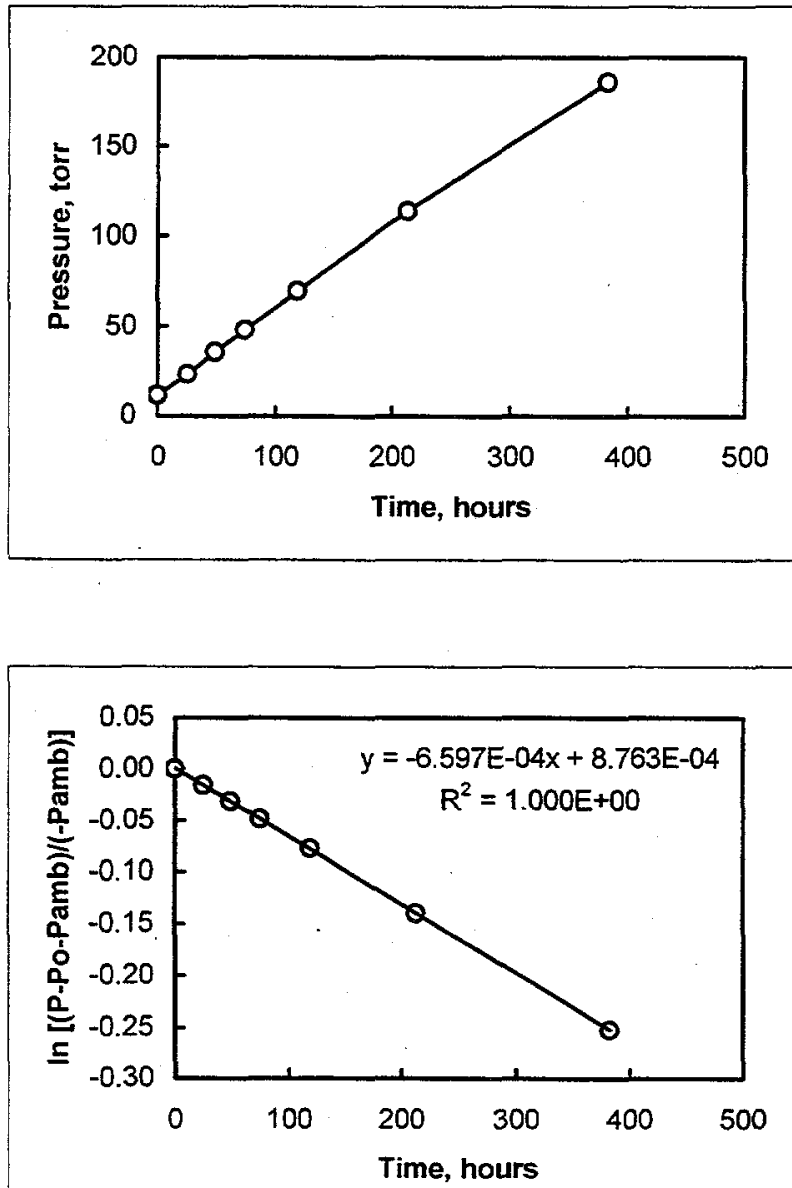
Film:

Panel Set:

E 92744-89-2 with Surlyn

Gas:

$$
\text { Helium }
$$

$P=P o+P a m b[1-\exp (-b t)]$

Panel $\quad V, c c \quad A$, in $^{2} \quad b \quad A / b$ Permeance

$\begin{array}{llllll}\text { B-II-1 } & 0 & 197 & 2.179 \mathrm{E}-03 & 9.041 \mathrm{E}+04 & 0.16\end{array}$

$\begin{array}{llllll}\text { B-II-2 } & 7.43 & 196 & 9.659 E-04 & 2.029 E+05 & 0.15\end{array}$

$\begin{array}{llllll}\text { B-II-3 } & 15.27 & 199 & 6.597 E-04 & 3.017 E+05 & 0.16\end{array}$

Permeance units $=c c(S T P) / 100$ in. $^{2} \cdot a t m \cdot d a y$

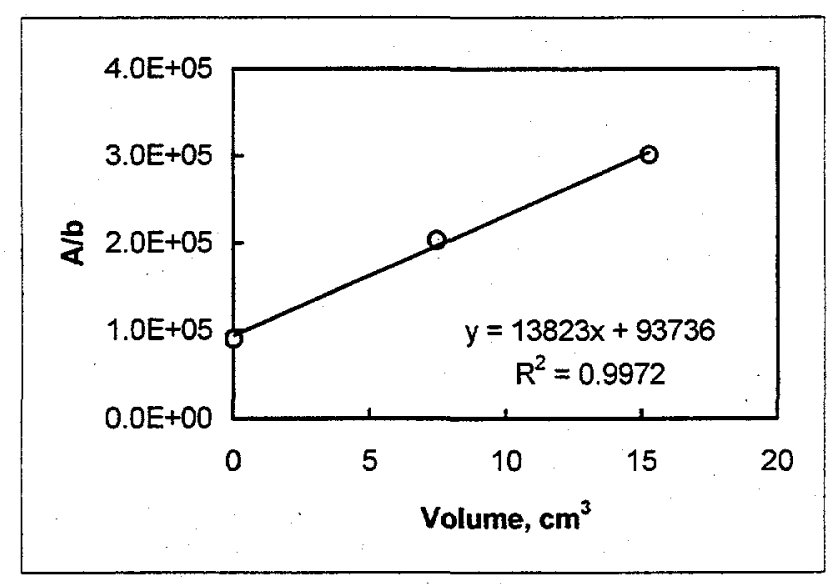

$V_{0}=\quad 6.8 \mathrm{~cm}^{3}$ 
Film:

E 51489-21-2

Panel:

C-I-1

Gas:

Air

Internal Volume:

$0 \mathrm{~cm}^{3}$

$\begin{array}{rrrr}\text { Date } & \text { Time } & \text { Hours } & P \text {, torr } \\ 6 / 27 / 96 & 8: 30 \mathrm{AM} & 0 & 3.6 \\ 7 / 31 / 96 & 12: 45 \mathrm{PM} & 820.25 & 7.8 \\ 9 / 6 / 96 & 1: 20 \mathrm{PM} & 1708.83 & 8.9 \\ 10 / 11 / 96 & 10: 00 \mathrm{AM} & 2545.5 & 10.9 \\ 11 / 26 / 96 & 10: 15 \mathrm{AM} & 3649.75 & 11.4 \\ 1 / 6 / 97 & 9: 00 \mathrm{AM} & 4872.5 & 12.5 \\ 2 / 28 / 97 & 10: 00 \mathrm{AM} & 5905.5 & 14.0 \\ 4 / 18 / 97 & 10: 45 \mathrm{AM} & 7082.25 & 14.6 \\ 5 / 28 / 97 & 10: 00 \mathrm{AM} & 8041.5 & 16.3 \\ 6 / 30 / 97 & 9: 30 \mathrm{AM} & 8833 & 18.3\end{array}$

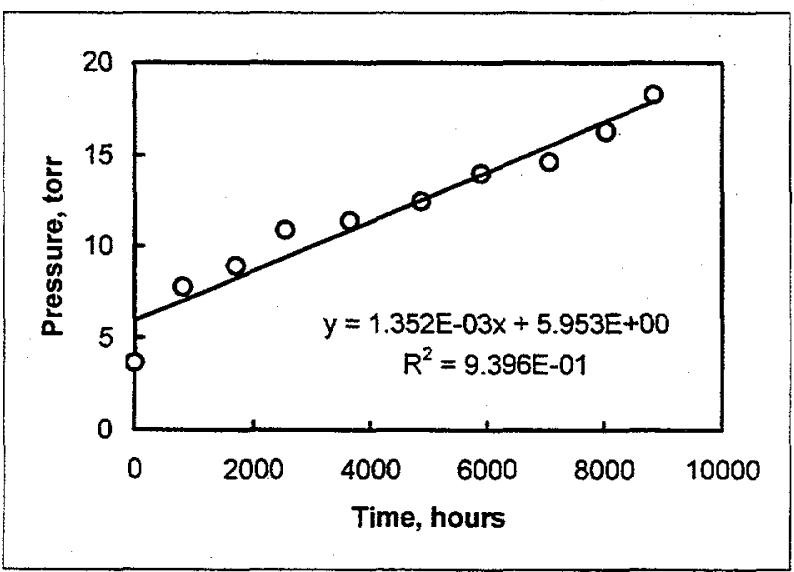


Film:

Panel:

E 51489-21-2

Gas:

C-I-2

Internal Volume: $\quad 7.66 \mathrm{~cm}^{3}$

$\begin{array}{rrrr}\text { Date } & \text { Time } & \text { Hours } & P, \text { torr } \\ 6 / 27 / 96 & 8: 30 \mathrm{AM} & 0 & 3.7 \\ 7 / 31 / 96 & 12: 45 \mathrm{PM} & 820.25 & 3.6 \\ 9 / 6 / 96 & 1: 20 \mathrm{PM} & 1708.83 & 5.2 \\ 10 / 11 / 96 & 10: 00 \mathrm{AM} & 2545.5 & 4.2 \\ 11 / 26 / 96 & 10: 15 \mathrm{AM} & 3649.75 & 4.2 \\ 1 / 6 / 97 & 9: 00 \mathrm{AM} & 4872.5 & 5.7 \\ 2 / 28 / 97 & 10: 00 \mathrm{AM} & 5905.5 & 3.6 \\ 4 / 18 / 97 & 10: 45 \mathrm{AM} & 7082.25 & 4.6 \\ 5 / 28 / 97 & 10: 00 \mathrm{AM} & 8041.5 & 6.2 \\ 6 / 30 / 97 & 9: 30 \mathrm{AM} & 8833 & 7.8\end{array}$

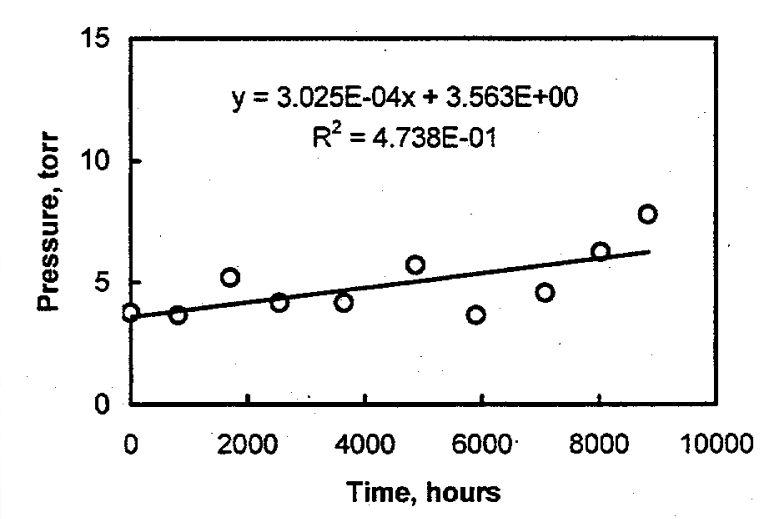


Film:

E 51489-21-2

Panel:

C-I-3

Gas:

Air

Internal Volume: $\quad 15.00 \mathrm{~cm}^{3}$

$\begin{array}{rrrr}\text { Date } & \text { Time } & \text { Hours } & P, \text { torr } \\ 6 / 27 / 96 & 8: 30 \mathrm{AM} & 0 & 2.1 \\ 7 / 31 / 96 & 12: 45 \mathrm{PM} & 820.25 & 3.4 \\ 9 / 6 / 96 & 1: 20 \mathrm{PM} & 1708.83 & 3.7 \\ 10 / 11 / 96 & 10: 00 \mathrm{AM} & 2545.5 & 3.9 \\ 11 / 26 / 96 & 10: 15 \mathrm{AM} & 3649.75 & 4.7 \\ 1 / 6 / 97 & 9: 00 \mathrm{AM} & 4872.5 & 4.4 \\ 2 / 28 / 97 & 10: 00 \mathrm{AM} & 5905.5 & 4.7 \\ 4 / 18 / 97 & 10: 45 \mathrm{AM} & 7082.25 & 5.2 \\ 5 / 28 / 97 & 10: 00 \mathrm{AM} & 8041.5 & 6.2 \\ 6 / 30 / 97 & 9: 30 \mathrm{AM} & 8833 & 6.2\end{array}$

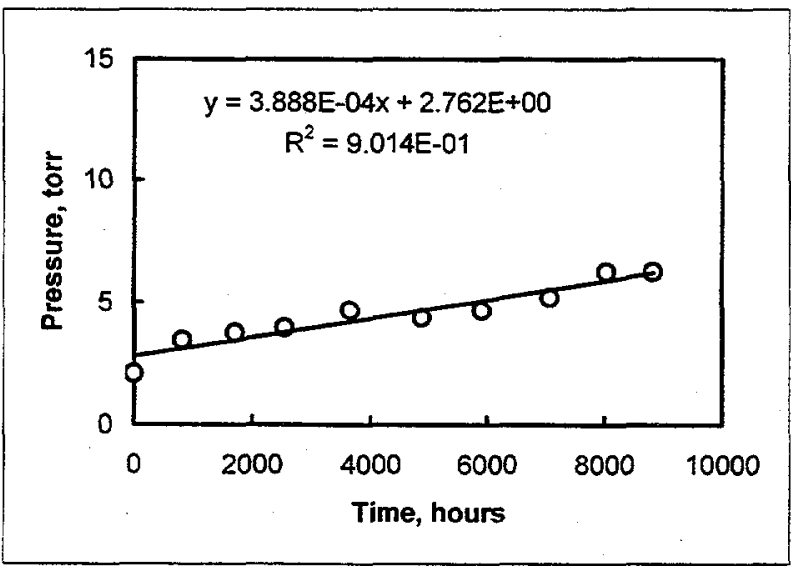


Film:

Panel Set:

E 51489-21-2

Gas:

C-I

Air

$P=a+b t$

\begin{tabular}{|c|c|c|c|c|c|c|}
\hline Panel & $V, c c$ & $A$, in. $^{2}$ & a & b & $A^{*}($ Pamb-a $) / b$ & Permeance \\
\hline $\mathrm{C}-\mathrm{I}-1$ & 0 & 198.4 & 5.953 & $1.352 E-03$ & $1.143 E+08$ & 0.00008 \\
\hline $\mathrm{C}-\mathrm{I}-2$ & 7.66 & 198.0 & 3.563 & $3.025 E-04$ & $5.115 E+08$ & 0.00005 \\
\hline C-I-3 & 15.00 & 198.4 & 2.762 & $3.888 E-04$ & $3.992 E+08$ & 0.00010 \\
\hline
\end{tabular}

Permeance units $=c c($ STP $) / 100{\text { in. }{ }^{2} \cdot a t m \cdot d a y}$

Used $V_{0}=4.3 \mathrm{~cm}^{3}$ as for runs in helium. 
Film:

E 51489-21-2

Panel:

Gas:

C-I-1

Internal Volume: $\quad 0 \mathrm{~cm}^{3}$

$\begin{array}{rrrr}\text { Date } & \text { Time } & \text { Hours } & P \text {, torr } \\ 6 / 30 / 97 & 10: 15 \mathrm{AM} & 0 & 18.3 \\ 7 / 1 / 97 & 10: 45 \mathrm{AM} & 24.5 & 28.0 \\ 7 / 2 / 97 & 10: 10 \mathrm{AM} & 47.4 & 39.5 \\ 7 / 4 / 97 & 9: 25 \mathrm{AM} & 94.6 & 60.9 \\ 7 / 7 / 97 & 8: 30 \mathrm{AM} & 165.2 & 95.6 \\ 7 / 11197 & 9: 00 \mathrm{AM} & 261.2 & 133.9\end{array}$
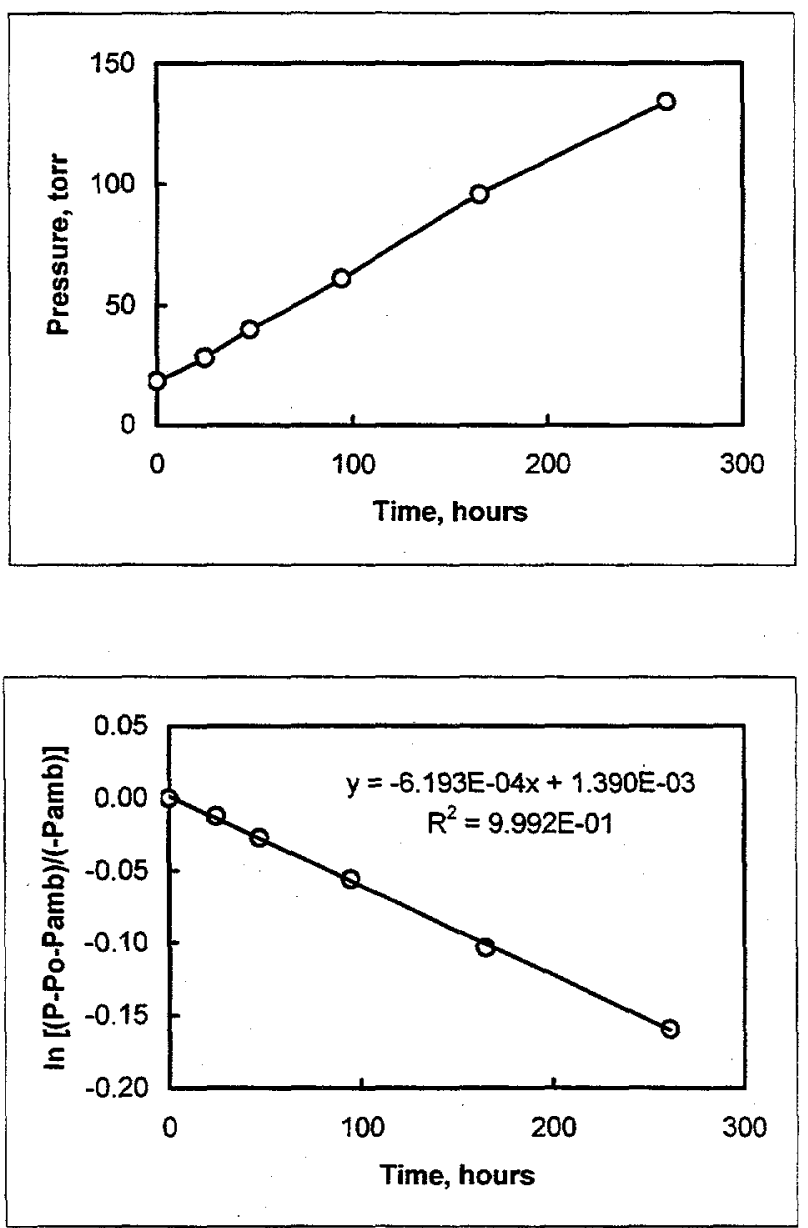
Film:

E 51489-21-2

Panel:

Gas:

C-I-2

Internal Volume: $\quad 7.66 \mathrm{~cm}^{3}$

$\begin{array}{rrrr}\text { Date } & \text { Time } & \text { Hours } & \text { P, torr } \\ 6 / 30 / 97 & 10: 15 \mathrm{AM} & 0 & 7.5 \\ 7 / 1 / 97 & 10: 45 \mathrm{AM} & 24.5 & 12 \\ 7 / 2 / 97 & 10: 10 \mathrm{AM} & 47.4 & 14.7 \\ 7 / 4 / 97 & 9: 25 \mathrm{AM} & 94.6 & 22.1 \\ 7 / 7 / 97 & 8: 30 \mathrm{AM} & 165.2 & 36.9 \\ 7 / 11 / 97 & 9: 00 \mathrm{AM} & 261.2 & 54 \\ 7 / 24 / 97 & 9: 45 \mathrm{AM} & 573 & 113.9\end{array}$
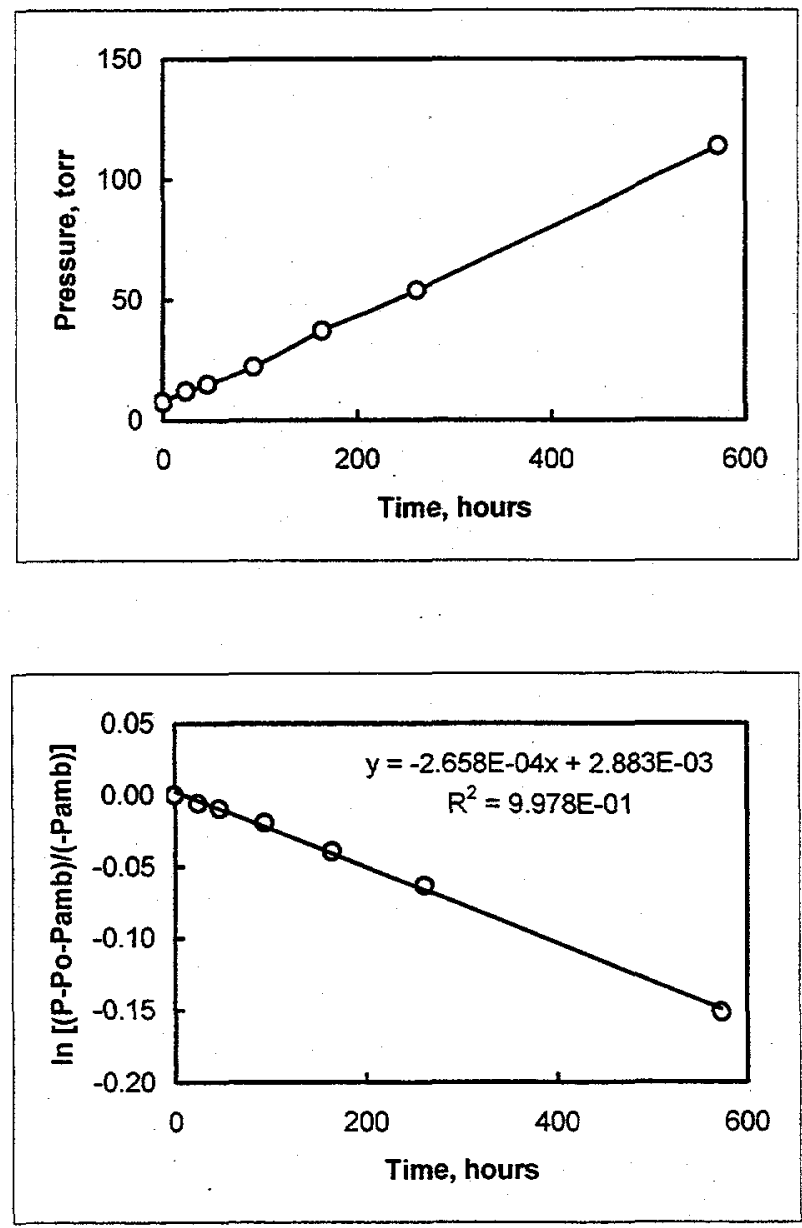
Film:

Panel:

Gas:

E 51489-21-2

Internal Volume:

C-1-3

Helium

$15.00 \mathrm{~cm}^{3}$

$\begin{array}{rrrr}\text { Date } & \text { Time } & \text { Hours } & \text { P, torr } \\ 6 / 30 / 97 & 10: 15 \mathrm{AM} & 0 & 6 \\ 7 / 1 / 97 & 10: 45 \mathrm{AM} & 24.5 & 8 \\ 7 / 2 / 97 & 10: 10 \mathrm{AM} & 47.4 & 10.2 \\ 7 / 4 / 97 & 9: 25 \mathrm{AM} & 94.6 & 14.1 \\ 7 / 7 / 97 & 8: 30 \mathrm{AM} & 165.2 & 21.3 \\ 7 / 11 / 97 & 9: 00 \mathrm{AM} & 261.2 & 31.1 \\ 7 / 24 / 97 & 9: 45 \mathrm{AM} & 573 & 62.3 \\ 8 / 6 / 97 & 10: 45 \mathrm{AM} & 885 & 100.7\end{array}$
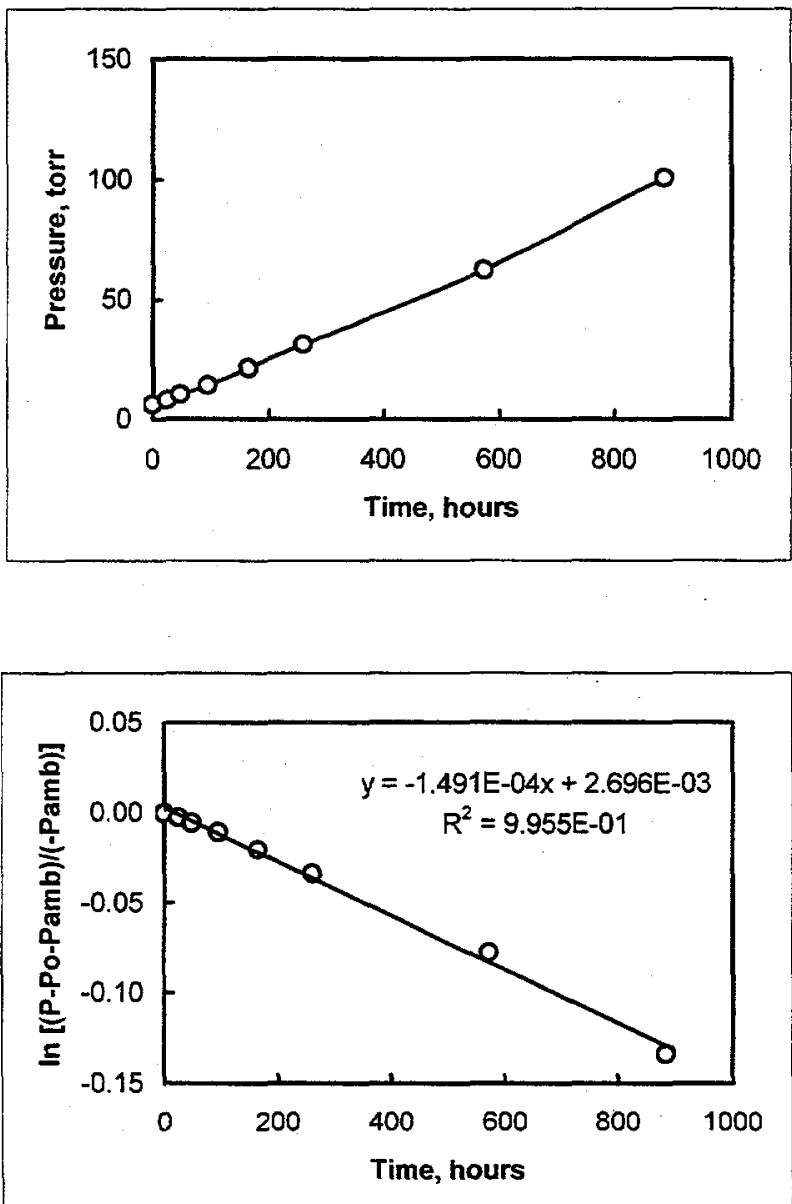
Film:

E 51489-21-2

Panel Set:

C-I

Gas:

Helium

$P=P o+P a m b[1-\exp (-b t)]$

Panel

C- $-1-1$

$V, c c$

$A$, in. $^{2}$

b

$\mathrm{A} / \mathrm{b}$ Permeance

$\mathrm{C}-\mathrm{I}-2$

7.66

198.4 6.193E-04 3.204E+05

0.029

C-l-3

15.00

198.0 2.658E-04 7.449E +05

0.034

198.4 1.491E-04 1.331E+06

Permeance units $=c c($ STP $) / 100$ in..$^{2} \cdot a t m \cdot d a y$

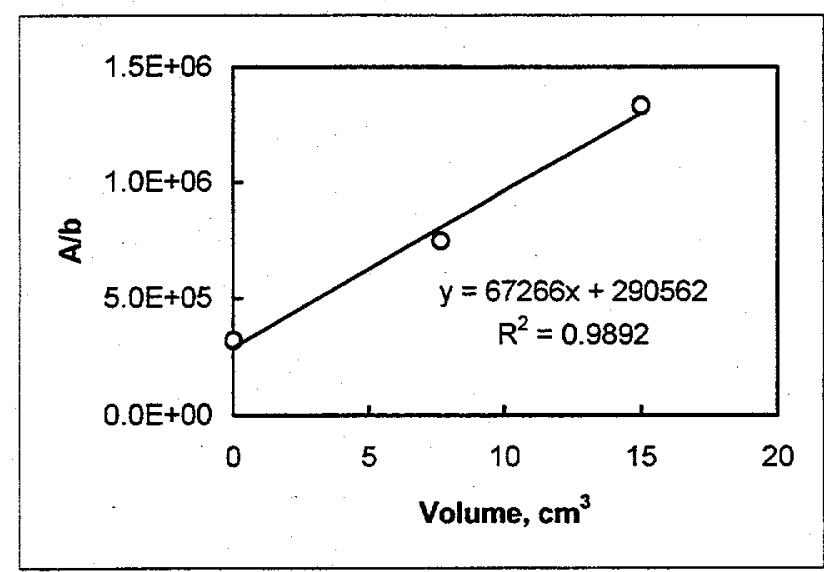
Vo $=$
$4.3 \mathrm{~cm}^{3}$ 


$\begin{array}{ll}\text { Film: } & \text { E 51489-21-2 } \\ \text { Panel: } & \text { C-1l-1 } \\ \text { Gas: } & \text { Air } \\ \text { Internal Volume: } & 0 \mathrm{~cm}^{3}\end{array}$

$\begin{array}{rrrr}\text { Date } & \text { Time } & \text { Hours } & P, \text { torr } \\ 1 / 16 / 97 & 9: 00 \mathrm{AM} & 0 & 4.8 \\ 2 / 28 / 97 & 10: 00 \mathrm{AM} & 1033 & 6.8 \\ 4 / 18 / 97 & 10: 45 \mathrm{AM} & 2209.75 & 8.3 \\ 5 / 28 / 97 & 10: 00 \mathrm{AM} & 3169 & 9.9 \\ 6 / 30 / 97 & 9: 30 \mathrm{AM} & 3960.5 & 10.3 \\ 8 / 7 / 98 & 8: 45 \mathrm{AM} & 4871.7 & 12.0 \\ 9 / 3 / 97 & 10: 00 \mathrm{AM} & 5521 & 11.9 \\ 10 / 17 / 97 & 10: 00 \mathrm{AM} & 6577 & 13.0 \\ 11 / 25 / 97 & 9: 15 \mathrm{AM} & 7512.25 & 13.6 \\ 1 / 7 / 98 & 9: 15 \mathrm{AM} & 8544 & 14.6 \\ 2 / 17 / 98 & 10: 00 \mathrm{AM} & 9528 & 15.6 \\ 3 / 17 / 98 & 2: 00 \mathrm{PM} & 10200 & 15.9 \\ 4 / 24 / 98 & 10: 00 \mathrm{AM} & 11112 & 16.6 \\ 6 / 4 / 98 & 9: 00 \mathrm{AM} & 12096 & 17.8\end{array}$

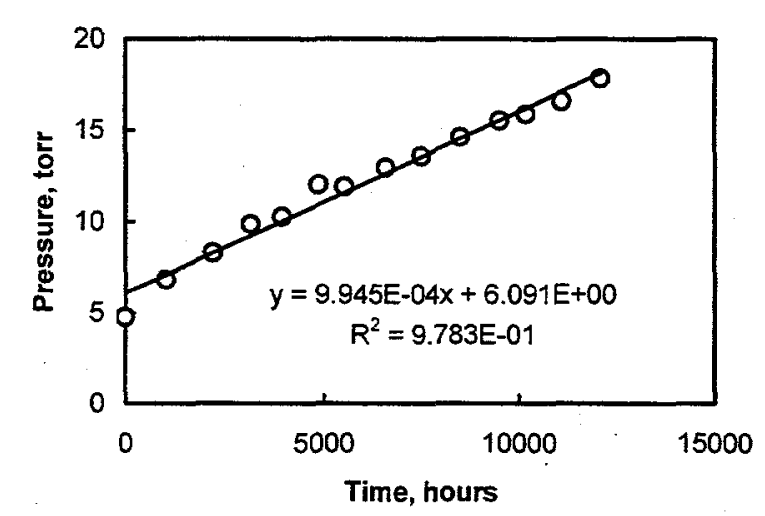


Film:

Panel:

Gas:

Internal Volume:

\section{E 51489-21-2}

C-II-2

Air

$7.66 \mathrm{~cm}^{3}$

$\begin{array}{rrrr}\text { Date } & \text { Time } & \text { Hours } & \text { P, torr } \\ \text { 1/16/97 } & 9: 00 \mathrm{AM} & 0 & 3.1 \\ 2 / 28 / 97 & 10: 00 \mathrm{AM} & 1033 & \text { Leaked }\end{array}$


Film:

Panel:

Gas:

Internal Volume:
E 51489-21-2

C-ll-3

Air

$15.24 \mathrm{~cm}^{3}$

$\begin{array}{rrrr}\text { Date } & \text { Time } & \text { Hours } & \mathrm{P}, \text { torr } \\ \text { 1/16/97 } & 9: 00 \mathrm{AM} & 0 & 2.6 \\ 2 / 28 / 97 & 10: 00 \mathrm{AM} & 1033 & 4.9 \\ \text { 4/18/97 } & 10: 45 \mathrm{AM} & 2209.75 & 3.6 . \\ 5 / 28 / 97 & 10: 00 \mathrm{AM} & 3169 & 3.7 \\ 6 / 30 / 97 & 9: 30 \mathrm{AM} & 3960.5 & 4.2\end{array}$

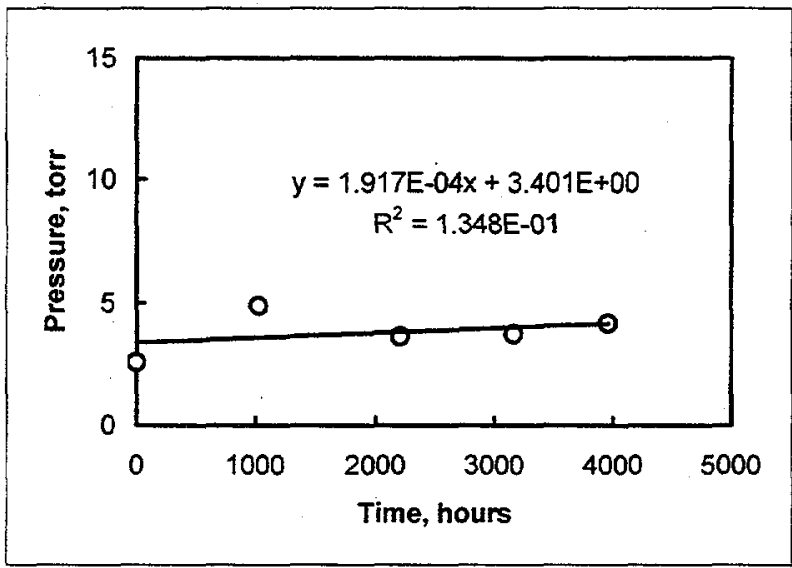


Film:

E 51489-21-2

Panel Set: C-II

Gas: Air

$P=a+b t$

\begin{tabular}{|c|c|c|c|c|c|}
\hline Panel & $V, c c$ & $A$, in. $^{2}$ & $\mathbf{a}$ & $A^{*}(P a m b-a) / b$ & Permeance \\
\hline C-II-1 & 0 & 199.0 & $6.0919 .945 E-04$ & $1.559 E+08$ & 0.00007 \\
\hline C-II-2 & 7.66 & 198.0 & ure rise too sma & late pe & neance. \\
\hline C-II-3 & 15.24 & & & & \\
\hline
\end{tabular}

Permeance units $=c c(S T P) / 100$ in. $^{2} \cdot$ atm $\cdot$ day

Vo assumed to be $5 \mathrm{~cm}^{3}$ 
Film:

E 51489-21-2

Panel:

C-III-1

Gas:

Helium

Internal Volume: $\quad 0 \mathrm{~cm}^{3}$

$\begin{array}{rrrr}\text { Date } & \text { Time } & \text { Hours } & \text { P, torr } \\ 3 / 19 / 97 & 9: 30 \mathrm{AM} & 0 & 3.1 \\ 3 / 20 / 97 & 8: 45 \mathrm{AM} & 23.25 & 16.8 \\ 3 / 21 / 97 & 10: 15 \mathrm{AM} & 48.25 & 31.5 \\ 3 / 24 / 97 & 2: 15 \mathrm{PM} & 123.75 & 79.1 \\ 3 / 27 / 97 & 10: 05 \mathrm{AM} & 191.08 & 110.3\end{array}$
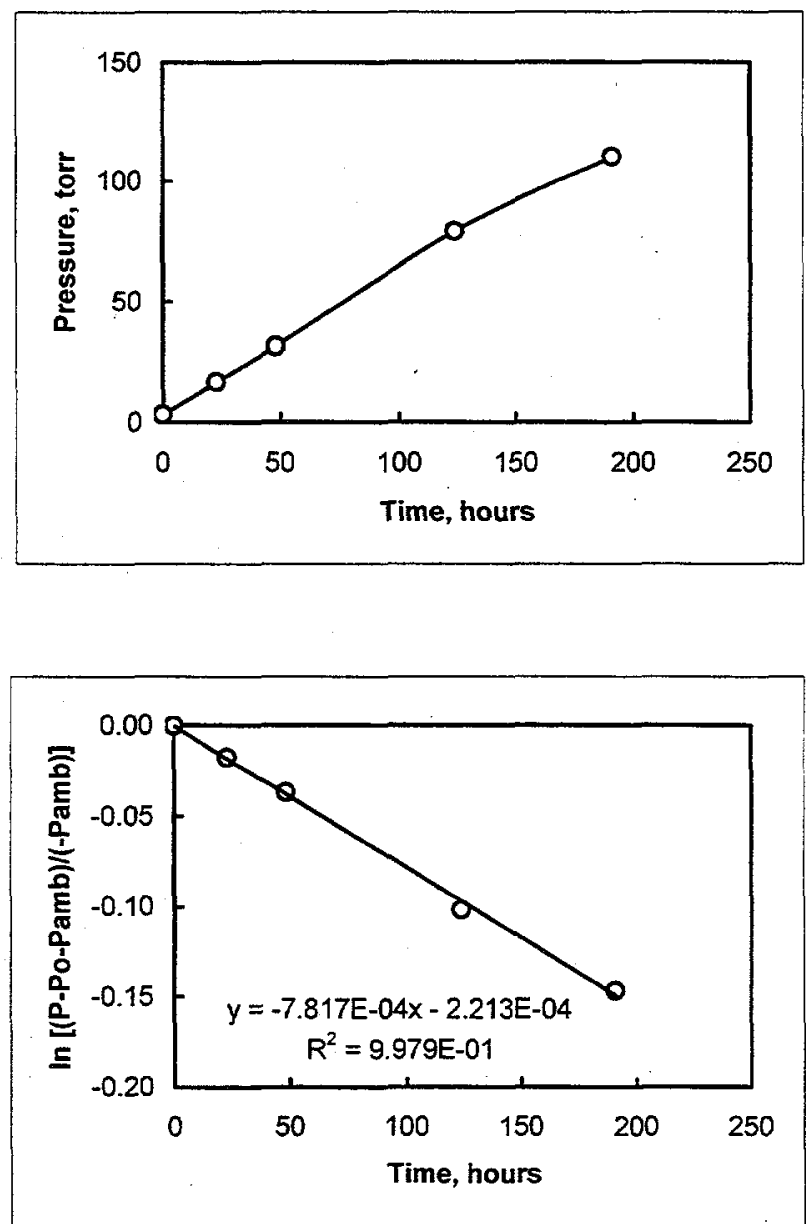
Film:

E 51489-21-2

Panel:

C-III-2

Gas:

Helium

Internal Volume: $\quad 7.43 \mathrm{~cm}^{3}$

$\begin{array}{rrrr}\text { Date } & \text { Time } & \text { Hours } & \text { P, torr } \\ 3 / 19 / 97 & 9: 30 \mathrm{AM} & 0 & 0.0 \\ 3 / 20 / 97 & 8: 45 \mathrm{AM} & 23.25 & 8.3 \\ 3 / 21 / 97 & 10: 15 \mathrm{AM} & 48.25 & 14.5 \\ 3 / 24 / 97 & 2: 15 \mathrm{PM} & 123.75 & 37.2 \\ 3 / 27 / 97 & 10: 05 \mathrm{AM} & 191.08 & 52.0 \\ 3 / 31 / 97 & 12: 55 \mathrm{PM} & 289.41 & 74.6 \\ 4 / 4 / 97 & 10: 15 \mathrm{AM} & 382.24 & 93.7 \\ 4 / 10 / 97 & 10: 00 \mathrm{AM} & 525.49 & 122.6\end{array}$
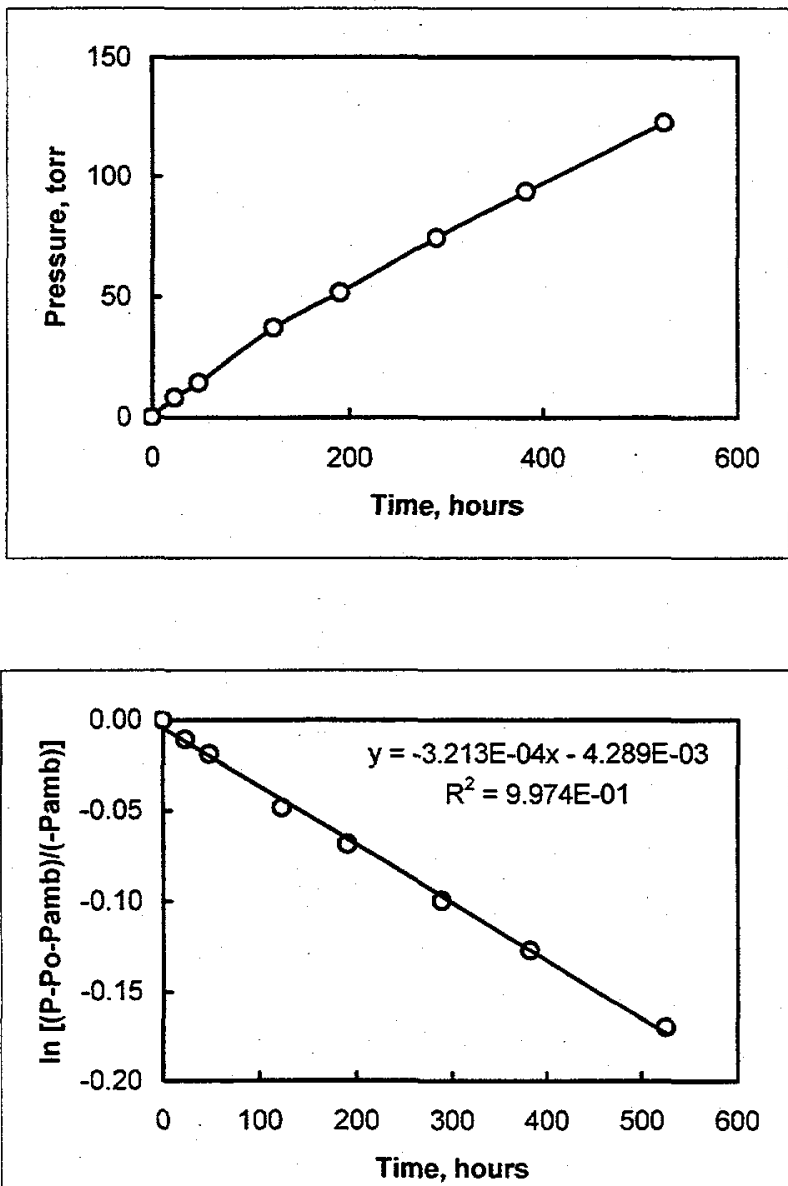
Film:

Panel:

Gas:

Internal Volume:
E 51489-21-2

C-III-3

Helium

$15.27 \mathrm{~cm}^{3}$

$\begin{array}{rrrr}\text { Date } & \text { Time } & \text { Hours } & P \text {, torr } \\ 3 / 19 / 97 & 9: 30 \text { AM } & 0 & 0.0 \\ 3 / 20 / 97 & 8: 45 \text { AM } & 23.25 & 5.2 \\ 3 / 21 / 97 & 10: 15 \text { AM } & 48.25 & 10.9 \\ 3 / 24 / 97 & 2: 15 \text { PM } & 123.75 & 21.2 \\ 3 / 27 / 97 & 10: 05 \text { AM } & 190.08 & 29.5 \\ 3 / 31 / 97 & 12: 55 \text { PM } & 289.41 & 43.4 \\ 4 / 4 / 97 & 10: 15 \text { AM } & 382.24 & 54.6 \\ 4 / 10 / 97 & 10: 00 \mathrm{AM} & 525.49 & 72.1 \\ 4 / 18 / 97 & 1: 30 \text { PM } & 720.49 & 96.4\end{array}$
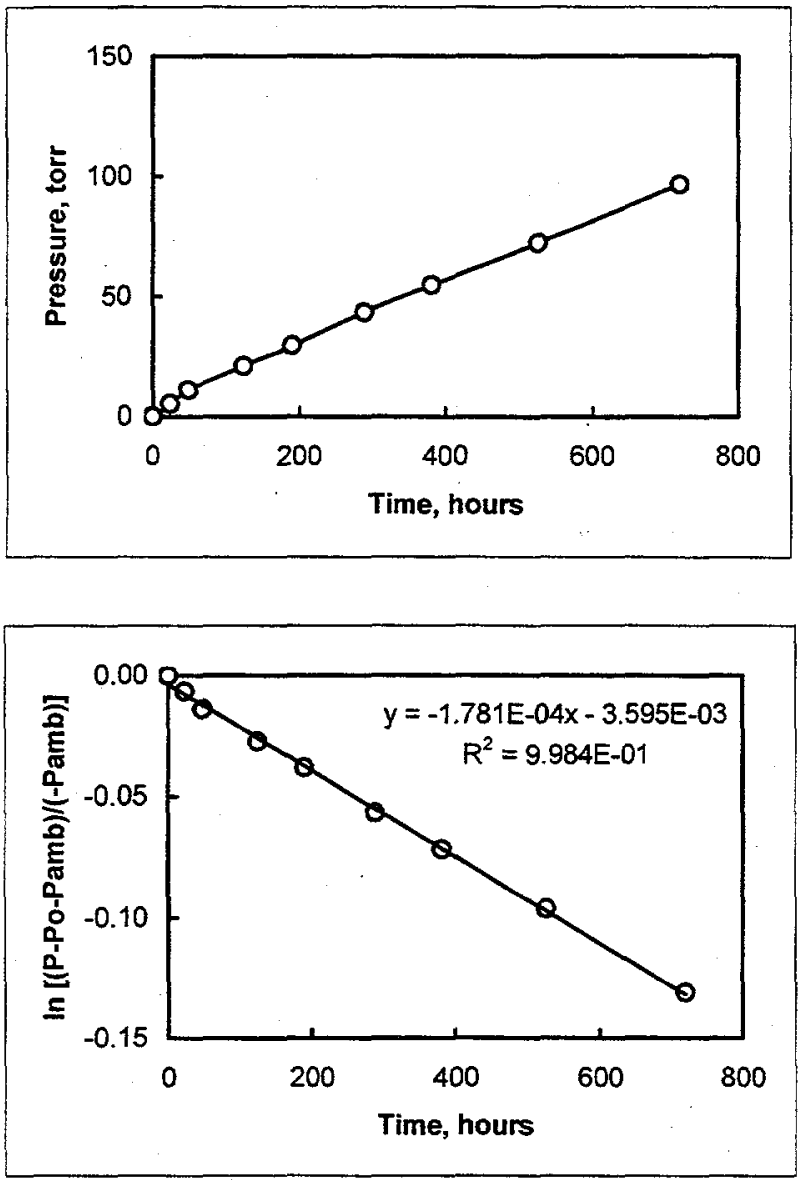
Film:

E 51489-21-2

Panel Set:

C-III

Gas:

Helium

$P=P o+P a m b[1-\exp (-b t)]$

Panel

V, $c c$

$$
A, \text { in. }^{2}
$$

b

Avb Permeance

C-III-1

7.43

201.0 7.817E-04 2.571E+05

0.037

C-III-2

15.27

199.0 3.213E-04 6.194E+05

0.041

C-III-3

$196.0 \quad 1.781 \mathrm{E}-04 \quad 1.101 \mathrm{E}+06$

Permeance units $=c c(S T P) / 100$ in. $^{2} \cdot$ atm $\cdot$ day

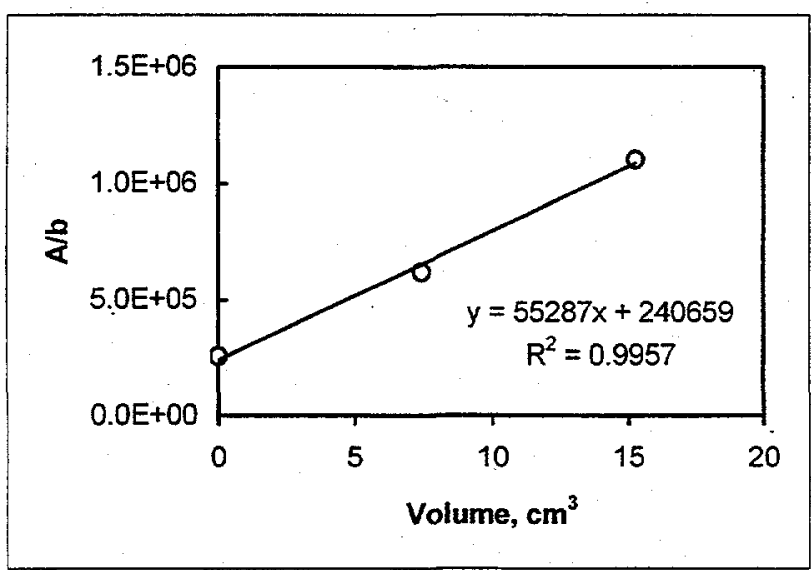

$V_{0}=\quad 4.4 \mathrm{~cm}^{3}$ 
Film:

E 48662-146-1

Panel:

D-I-1

Gas:

Air

Internal Volume: $\quad 0 \mathrm{~cm}^{3}$

$\begin{array}{rrrr}\text { Date } & \text { Time } & \text { Hours } & P, \text { torr } \\ 6 / 19 / 96 & 8: 00 \mathrm{AM} & 0 & 2.6 \\ 6 / 27 / 96 & 8: 30 \mathrm{AM} & 192.5 & 6.2 \\ 7 / 31 / 96 & 12: 45 \mathrm{PM} & 1012.75 & 6.2 \\ 9 / 6 / 96 & 1: 20 \mathrm{PM} & 1901.3 & 6.2 \\ 10 / 11 / 96 & 10: 00 \mathrm{AM} & 2738 & 5.7 \\ 11 / 26 / 96 & 10: 15 \mathrm{AM} & 3842.25 & 6.2 \\ 1 / 6 / 97 & 9: 00 \mathrm{AM} & 5065 & 6.3 \\ 2 / 28 / 97 & 10: 00 \mathrm{AM} & 6098 & 6.7 \\ 4 / 18 / 97 & 10: 45 \mathrm{AM} & 7274.75 & 6.8 \\ 5 / 28 / 97 & 10: 00 \mathrm{AM} & 8234 & 7.5 \\ 6 / 30 / 97 & 9: 30 \mathrm{AM} & 9025.5 & 8.5\end{array}$

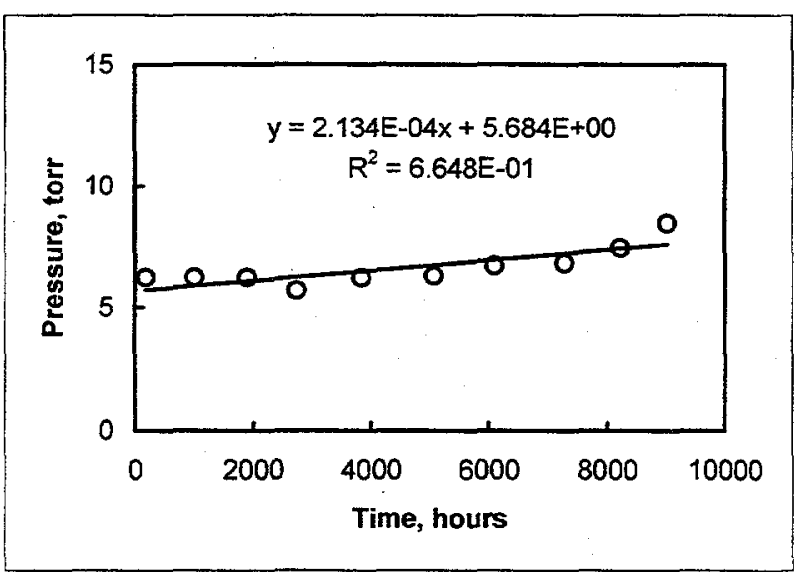


Film:

E 48662-146-1

Panel:

D-1-2

Gas:

Air

Internal Volume: $\quad 7.69 \mathrm{~cm}^{3}$

$\begin{array}{rrrr}\text { Date } & \text { Time } & \text { Hours } & P \text {, torr } \\ 6 / 19 / 96 & 8: 00 \mathrm{AM} & 0 & 2.6 \\ 6 / 27 / 96 & 8: 30 \mathrm{AM} & 192.5 & 4.8 \\ 7 / 31 / 96 & 12: 45 \mathrm{PM} & 1012.75 & 4.8 \\ 9 / 6 / 96 & 1: 20 \mathrm{PM} & 1901.3 & 4.4 \\ 10 / 11 / 96 & 10: 00 \mathrm{AM} & 2738 & 4.4 \\ 11 / 26 / 96 & 10: 15 \mathrm{AM} & 3842.25 & 3.9 \\ 1 / 6 / 97 & 9: 00 \mathrm{AM} & 5065 & 4.2 \\ 2 / 28 / 97 & 10: 00 \mathrm{AM} & 6098 & 3.8 \\ 4 / 18 / 97 & 10: 45 \mathrm{AM} & 7274.75 & 4.6 \\ 5 / 28 / 97 & 10: 00 \mathrm{AM} & 8234 & 5.0 \\ 6 / 30 / 97 & 9: 30 \mathrm{AM} & 9025.5 & 5.3\end{array}$

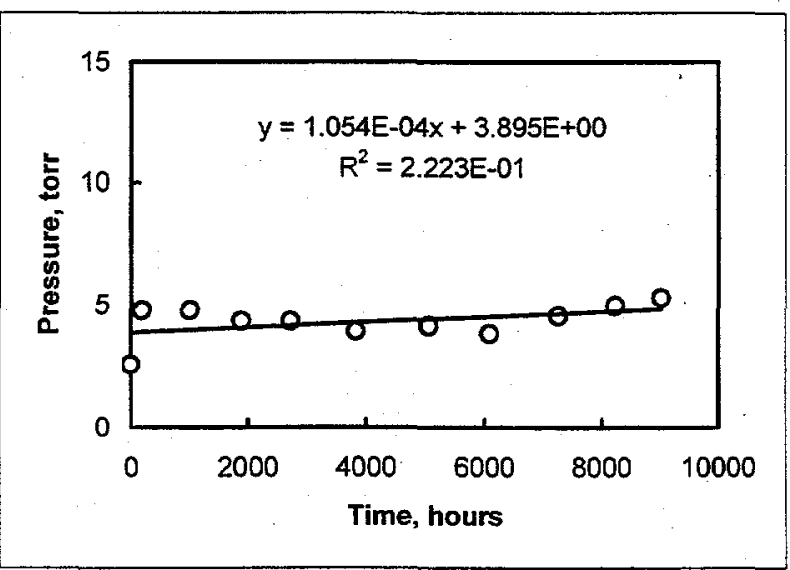


Film:

E 48662-146-1

Panel:

D-I-3

Gas:

Air

Internal Volume:

$14.76 \mathrm{~cm}^{3}$

$\begin{array}{rrrr}\text { Date } & \text { Time } & \text { Hours } & \text { P, torr } \\ 6 / 19 / 96 & 8: 00 \mathrm{AM} & 0 & 2.6 \\ 6 / 27 / 96 & 8: 30 \mathrm{AM} & 192.5 & 2.8 \\ 7 / 31 / 96 & 12: 45 \mathrm{PM} & 1012.75 & 2.8 \\ 9 / 6 / 96 & 1: 20 \mathrm{PM} & 1901.3 & 2.8 \\ 10 / 11 / 96 & 10: 00 \mathrm{AM} & 2738 & 2.6 \\ 11 / 26 / 96 & 10: 15 \mathrm{AM} & 3842.25 & 2.6 \\ 1 / 6 / 97 & 9: 00 \mathrm{AM} & 5065 & 3.1 \\ 2 / 28 / 97 & 10: 00 \mathrm{AM} & 6098 & 2.6 \\ 4 / 18 / 97 & 10: 45 \mathrm{AM} & 7274.75 & 2.1 \\ 5 / 28 / 97 & 10: 00 \mathrm{AM} & 8234 & 3.6 \\ 6 / 30 / 97 & 9: 30 \mathrm{AM} & 9025.5 & 4.2\end{array}$

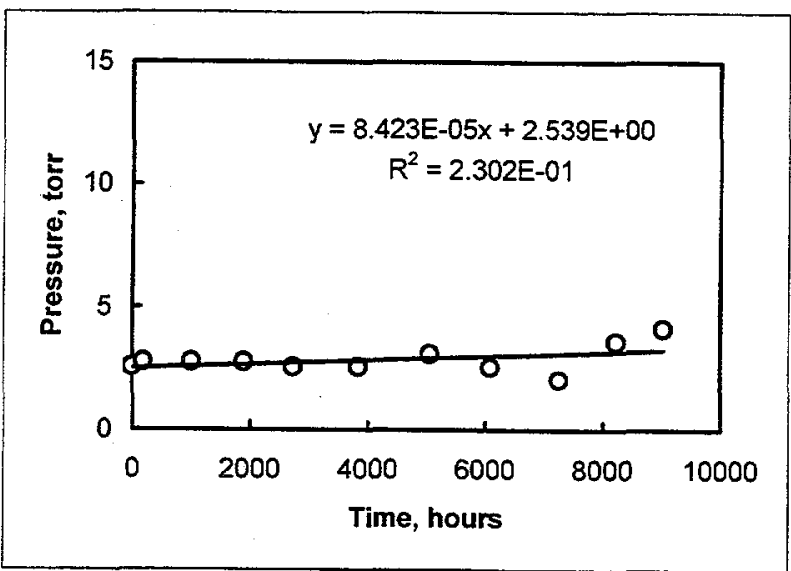


Film: E 48662-146-1

Panel Set:

$$
\text { D-I }
$$

Gas:

Air

$$
P=a+b t
$$

\begin{tabular}{lrrrrrr} 
Panel & V, cc & A, in. ${ }^{2}$ & \multicolumn{3}{c}{ a } & \multicolumn{3}{c}{$b$} & $A^{*}($ Pamb-a) $/ \mathrm{b}$ & Permeance \\
D-I-1 & 0 & 199.0 & 5.684 & $2.134 \mathrm{E}-04$ & $7.267 \mathrm{E}+08$ & 0.00002 \\
D-I-2 & 7.69 & 198.4 & 3.895 & $1.054 \mathrm{E}-04$ & $1.470 \mathrm{E}+09$ & 0.00002 \\
D-I-3 & 14.76 & 199.0 & 2.539 & $8.423 \mathrm{E}-05$ & $1.849 \mathrm{E}+09$ & 0.00002
\end{tabular}

Permeance units $=c c($ STP $) / 100$ in. $^{2} \cdot a t m \cdot d a y$

Used $V_{0}=5.1 \mathrm{~cm}^{3}$ as for runs in helium. 
Film:

E 48662-146-1

Panel:

D-1-1

Gas:

Helium

Internal Volume: $\quad 0 \mathrm{~cm}^{3}$

$\begin{array}{rrrr}\text { Date } & \text { Time } & \text { Hours } & \text { P, torr } \\ 6 / 30 / 97 & 10: 15 \mathrm{AM} & 0 & 8.5 \\ 7 / 1 / 97 & 10: 45 \mathrm{AM} & 24.5 & 13.6 \\ 7 / 2 / 97 & 10: 10 \mathrm{AM} & 47.4 & 19.0 \\ 7 / 4 / 97 & 9: 25 \mathrm{AM} & 94.6 & 30.7 \\ 7 / 7 / 97 & 8: 30 \mathrm{AM} & 165.2 & 48.0 \\ 7 / 11 / 97 & 9: 00 \mathrm{AM} & 261.2 & 71.1 \\ 7 / 24 / 97 & 9: 45 \mathrm{AM} & 573 & 143.4\end{array}$
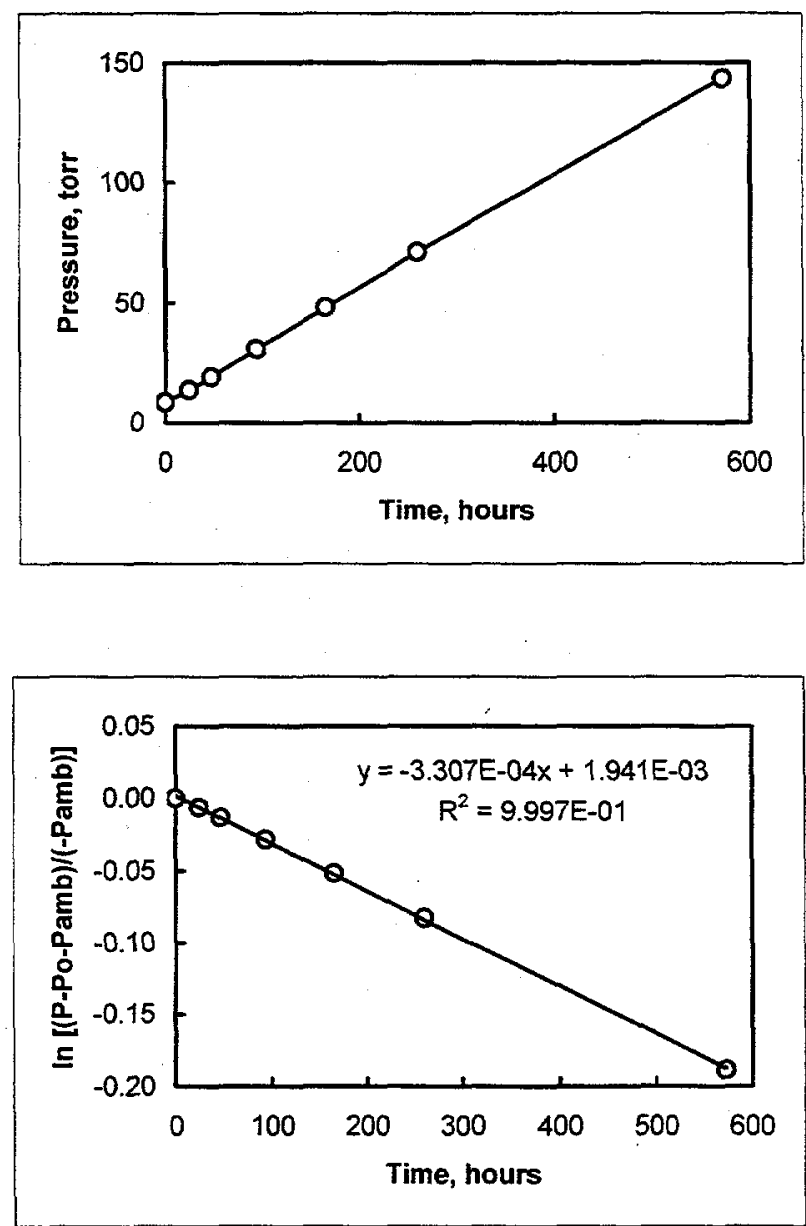
Film:

E 48662-146-1

Panel:

D-1-2

Gas:

Helium

Internal Volume: $\quad 7.69 \mathrm{~cm}^{3}$

$\begin{array}{rrrr}\text { Date } & \text { Time } & \text { Hours } & \text { P, torr } \\ 6 / 30 / 97 & 10: 15 \mathrm{AM} & 0 & 5.3 \\ 7 / 1 / 97 & 10: 45 \mathrm{AM} & 24.5 & 7.4 \\ 7 / 2 / 97 & 10: 10 \mathrm{AM} & 47.4 & 9.8 \\ 7 / 4 / 97 & 9: 25 \mathrm{AM} & 94.6 & 14.1 \\ 7 / 7 / 97 & 8: 30 \mathrm{AM} & 165.2 & 21.3 \\ 7 / 11 / 97 & 9: 00 \mathrm{AM} & 261.2 & 31.3 \\ 7 / 24 / 97 & 9: 45 \mathrm{AM} & 573 & 61.5 \\ 8 / 6 / 97 & 10: 45 \mathrm{AM} & 885 & 90.7 \\ 8 / 11 / 97 & 8: 45 \mathrm{AM} & 998.8 & 101.7 \\ 8 / 16 / 97 & 1: 55 \mathrm{PM} & 1123.5 & 112.0\end{array}$
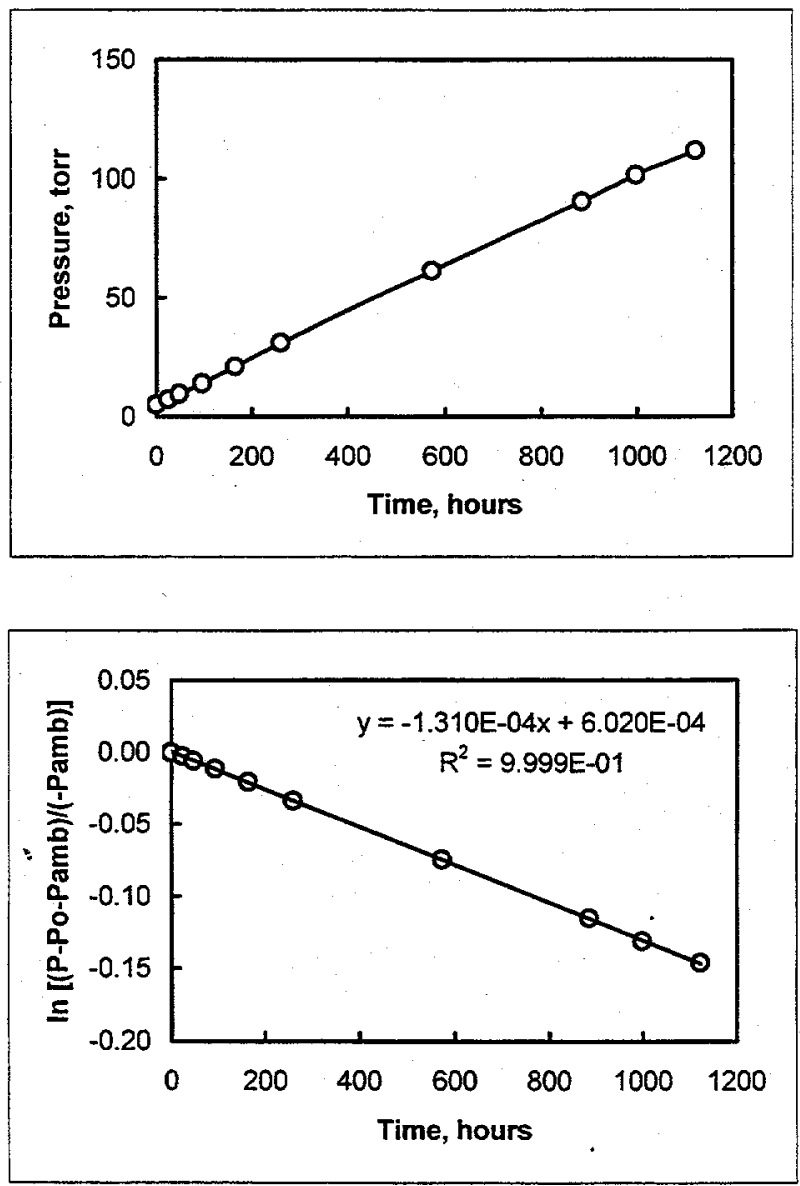
Film:

E 48662-146-1

Panel:

D-1-3

Gas:

Helium

Internal Volume:

$14.76 \mathrm{~cm}^{3}$

$\begin{array}{rrrr}\text { Date } & \text { Time } & \text { Hours } & \text { P, torr } \\ 6 / 30 / 97 & 10: 15 \mathrm{AM} & 0 & 4.2 \\ 7 / 1 / 97 & 10: 45 \mathrm{AM} & 24.5 & 5.3 \\ 7 / 2 / 97 & 10: 10 \mathrm{AM} & 47.4 & 7.0 \\ 7 / 4 / 97 & 9: 25 \mathrm{AM} & 94.6 & 10.9 \\ 7 / 7 / 97 & 8: 30 \mathrm{AM} & 165.2 & 16.0 \\ 7 / 11 / 97 & 9: 00 \mathrm{AM} & 261.2 & 25.9 \\ 7 / 24 / 97 & 9: 45 \mathrm{AM} & 573 & 54.5 \\ 8 / 6 / 97 & 10: 45 \mathrm{AM} & 885 & 84.6 \\ 8 / 11197 & 8: 45 \mathrm{AM} & 998.8 & 96.1 \\ 8 / 16 / 97 & 1: 55 \mathrm{PM} & 1123.5 & 107.7\end{array}$
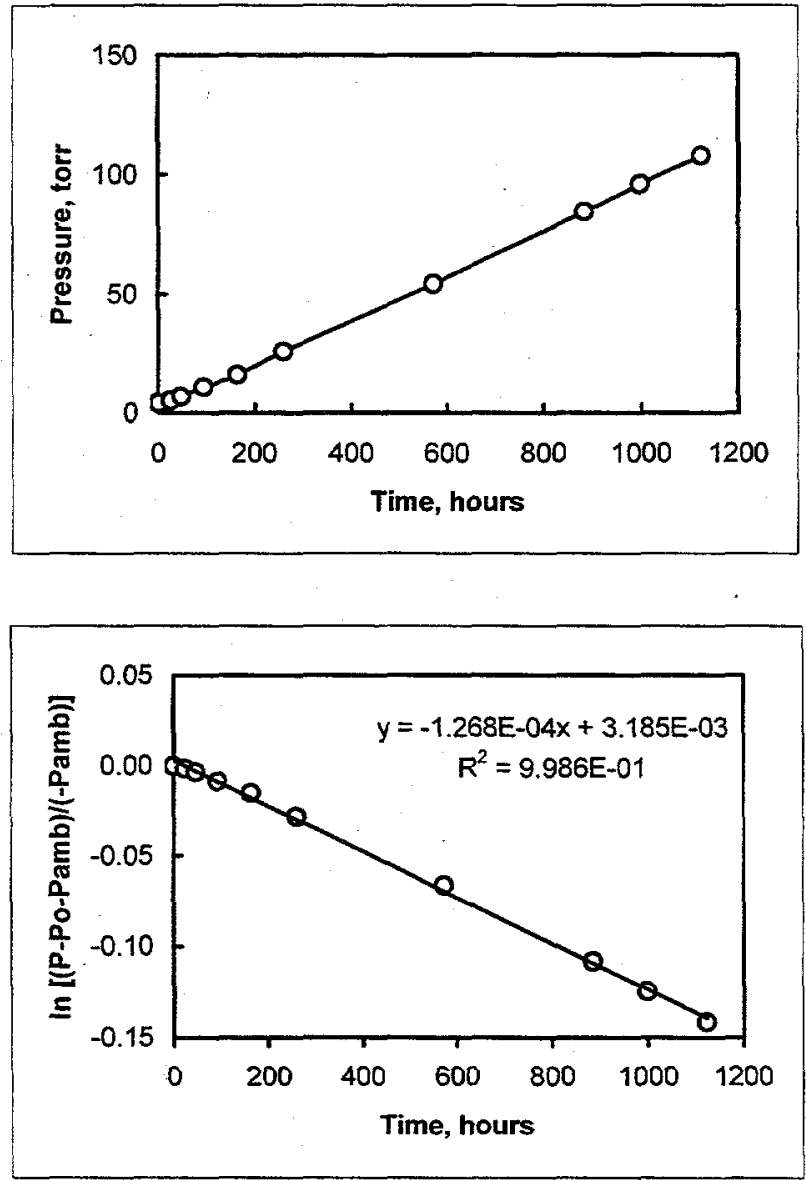
Film:

E 48662-146-1

Panel Set:

D-1

Gas:

Helium

$P=P o+P a m b[1-\exp (-b t)]$

\begin{tabular}{lrrrrr} 
Panel & V, cc & A, in. ${ }^{2}$ & b & \multicolumn{2}{c}{ Alb Permeance } \\
D-l-1 & 0 & 199.0 & $3.307 E-04$ & $6.018 E+05$ & 0.018 \\
D-l-2 & 7.69 & 198.4 & $1.310 E-04$ & $1.515 E+06$ & 0.018 \\
D-l-3 & 14.76 & 199.0 & $1.268 E-04$ & $1.569 E+06$ & $?$
\end{tabular}

Permeance units $=c c(S T P) / 100$ in. $^{2} \cdot$ atm $\bullet$ day

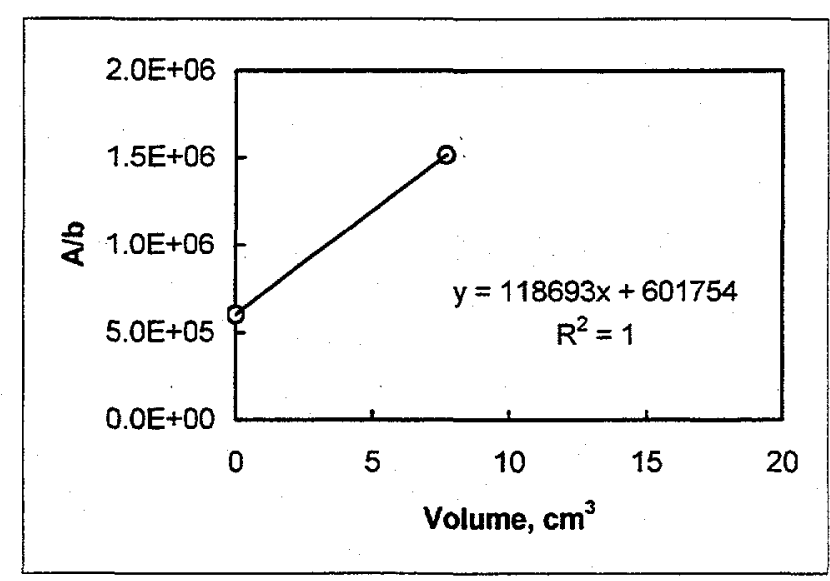

$V_{0}=\quad 5.1 \mathrm{~cm}^{3}$

Note: data for panel D-I-3 not used since P-t data are concave upwards. 
Film:

E 48662-146-1

Panel:

Gas:

D-II-1

Internal Volume:

Air

$0 \mathrm{~cm}^{3}$

$\begin{array}{rrrr}\text { Date } & \text { Time } & \text { Hours } & P \text {, torr } \\ 11 / 26 / 99 & 10: 15 \mathrm{AM} & 0 & 4.2 \\ 1 / 16 / 97 & 9: 00 \mathrm{AM} & 1222.75 & 6.2 \\ 2 / 28 / 97 & 10: 00 \mathrm{AM} & 2255.75 & 6.7 \\ 4 / 18 / 97 & 10: 45 \mathrm{AM} & 3432.25 & 7.0 \\ 5 / 28 / 97 & 10: 00 \mathrm{AM} & 4391.5 & 7.8 \\ 6 / 30 / 97 & 9: 30 \mathrm{AM} & 5183 & 7.8 \\ 8 / 7 / 97 & 8: 45 \mathrm{AM} & 6094.2 & 9.0 \\ 9 / 3 / 97 & 10: 00 \mathrm{AM} & 6743.4 & 7.8 \\ 10 / 17 / 97 & 10: 00 \mathrm{AM} & 7799 & 8.3 \\ 11 / 25 / 97 & 9: 15 \mathrm{AM} & 8734.25 & 8.7 \\ 1 / 7 / 98 & 9: 15 \mathrm{AM} & 9766 & 9.1 \\ 2 / 17 / 98 & 10: 00 \mathrm{AM} & 10750 & 9.3\end{array}$

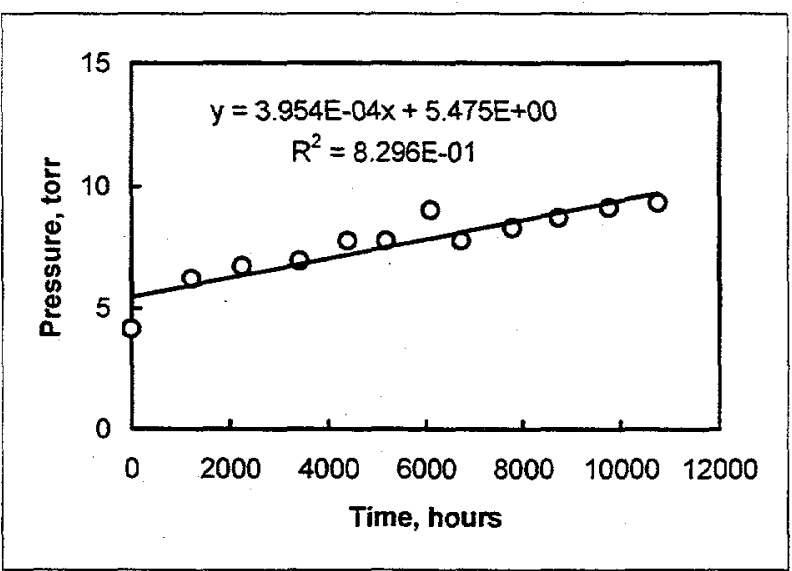


Film:

E 48662-146-1

Panel:

D-II-2

Gas:

Air

Internal Volume: $\quad 7.51 \mathrm{~cm}^{3}$

Date Time Hours $P$, torr

$\begin{array}{rrrr}11 / 26 / 99 & 10: 15 \text { AM } & 0 & 3 \\ 1 / 16 / 97 & 9: 00 \text { AM } & 1222.75 & 3.8 \\ 2 / 28 / 97 & 10: 00 \text { AM } & 2255.75 & 4.2\end{array}$

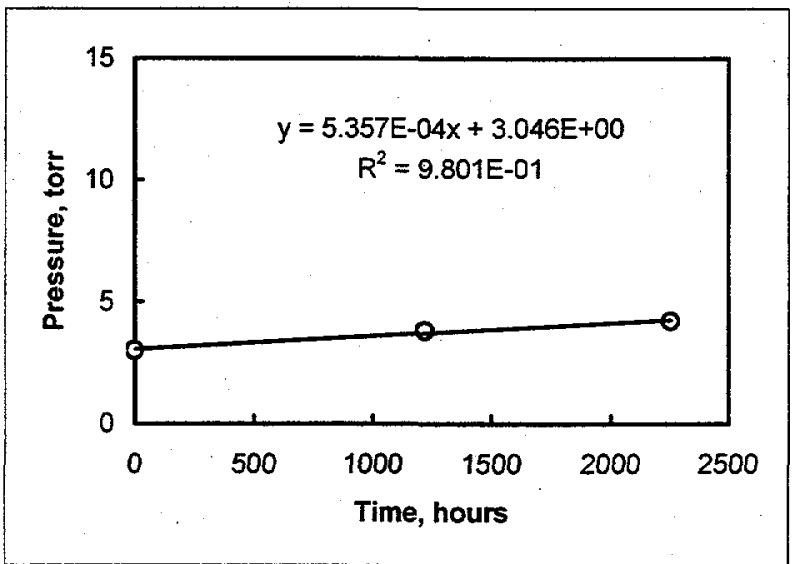


Film:

E 48662-146-1

Panel:

D-II-3

Gas:

Air

Internal Volume:

$15.20 \mathrm{~cm}^{3}$

$\begin{array}{rrrr}\text { Date } & \text { Time } & \text { Hours } & \text { P, torr } \\ 11 / 26 / 99 & 10: 15 \mathrm{AM} & 0 & 6.2 \\ 1 / 16 / 97 & 9: 00 \mathrm{AM} & 1222.75 & 6.2 \\ 2 / 28 / 97 & 10: 00 \mathrm{AM} & 2255.75 & 6.2 \\ 4 / 18 / 97 & 10: 45 \mathrm{AM} & 3432.25 & 5.2 \\ 5 / 28 / 97 & 10: 00 \mathrm{AM} & 4391.5 & 5.2 \\ 6 / 30 / 97 & 9: 30 \mathrm{AM} & 5183 & 5.2 \\ 8 / 7 / 97 & 8: 45 \mathrm{AM} & 6094.2 & 5.2 \\ 9 / 3 / 97 & 10: 00 \mathrm{AM} & 6743.4 & 4.7 \\ 10 / 17 / 97 & 10: 00 \mathrm{AM} & 7799 & 6.2\end{array}$

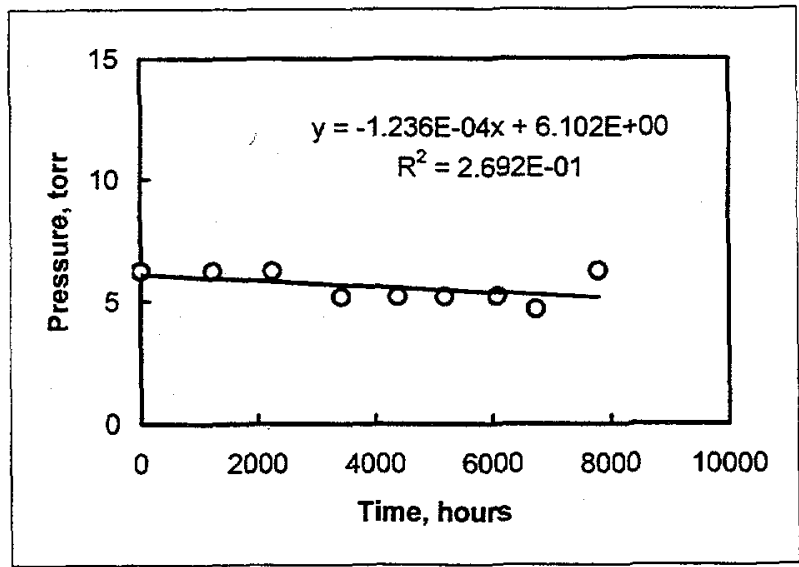


Film:

E 48662-146-1

Panel Set:

D-II

Gas:

Air

$P=a+b t$

\begin{tabular}{|c|c|c|c|c|}
\hline Panel & $V, c c$ & $A$, in. $^{2}$ & a & $A^{*}($ Pamb-a $) / b$ Permeance \\
\hline D-II-1 & 0 & 197.0 & 5.475 3.954E-04 & $3.884 E+08$ \\
\hline$D-\|-2$ & 7.51 & 200.0 & e ris & $\mathrm{ce}$ \\
\hline D-1I-3 & 15.20 & 199. & too sm & I to calculate permeance. \\
\hline
\end{tabular}

Permeance units $=c c($ STP $) / 100$ in..$^{2} \cdot$ atm $\cdot$ day

Vo assumed to be $5 \mathrm{~cm}^{3}$ 
Film:

E 48662-146-2

Panel:

E-1-1

Gas:

Air

Internal Volume: $\quad 0 \mathrm{~cm}^{3}$

$\begin{array}{rrrr}\text { Date } & \text { Time } & \text { Hours } & P \text {, torr } \\ 7 / 12 / 96 & 8: 00 \mathrm{AM} & 0 & 3.1 \\ 7 / 31 / 96 & 2: 00 \mathrm{PM} & 459.5 & 5.2 \\ 9 / 6 / 96 & 1: 20 \mathrm{PM} & 1346.8 & 5.7 \\ \text { 10/11/96 } & 10: 00 \mathrm{AM} & 2183.5 & 6.2 \\ 11 / 26 / 96 & 10: 15 \mathrm{AM} & 3287.75 & 6.5\end{array}$

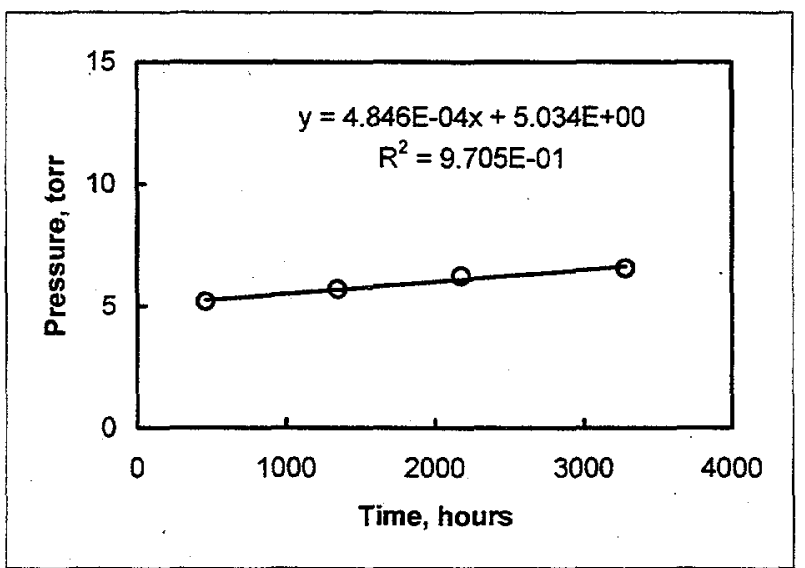


Film:

E 48662-146-2

Panel:

E-I-2

Gas:

Air

Internal Volume: $\quad 7.43 \mathrm{~cm}^{3}$

Date Time

7/12/96 10:30 AM

7/31/96 2:00 PM

9/6/96 1:20 PM

10/11/96 10:00 AM

11/26/96 10:15 AM

1/16/97 9:00 AM

2/28/97 10:00 AM

4/18/97 10:45 AM

5/28/97 10:00 AM

6/30/97 9:30 AM

8/7/97 8:45 AM
Hours

459.5

1346.8

2183.5

3287.75

4510.5

5543.5

6720.25

7679.5

8471

9382.25
P, torr

3.1

3.6

3.6

3.1

3.6

3.2

3.3

3.9

5.1

5.4

5.2

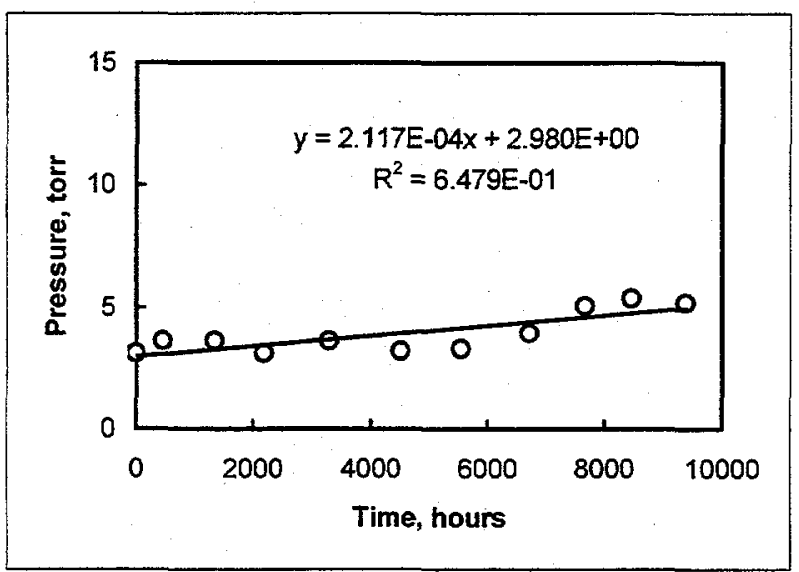


Film:

Panel:

Gas:

E 48662-146-2

Internal Volume:

E-1-3

Air

$15.27 \mathrm{~cm}^{3}$

$\begin{array}{rrrr}\text { Date } & \text { Time } & \text { Hours } & \mathrm{P}, \text { torr } \\ 7 / 12 / 96 & 10: 30 \mathrm{AM} & 0 & 3.1 \\ 7 / 31 / 96 & 2: 00 \mathrm{PM} & 459.5 & 3.6 \\ 9 / 6 / 96 & 1: 20 \mathrm{PM} & 1346.8 & 4.2 \\ 10 / 11 / 96 & 10: 00 \mathrm{AM} & 2183.5 & 3.1 \\ 11 / 26 / 96 & 10: 15 \mathrm{AM} & 3287.75 & 3.1 \\ 1 / 16 / 97 & 9: 00 \mathrm{AM} & 4510.5 & 4.7 \\ 2 / 28 / 97 & 10: 00 \mathrm{AM} & 5543.5 & 3.6 \\ 4 / 18 / 97 & 10: 45 \mathrm{AM} & 6720.25 & 3.6 \\ 5 / 28 / 97 & 10: 00 \mathrm{AM} & 7679.5 & 3.7 \\ 6 / 30 / 97 & 9: 30 \mathrm{AM} & 8471 & 3.9 \\ 8 / 7 / 97 & 8: 45 \mathrm{AM} & 9382.25 & 3.2\end{array}$

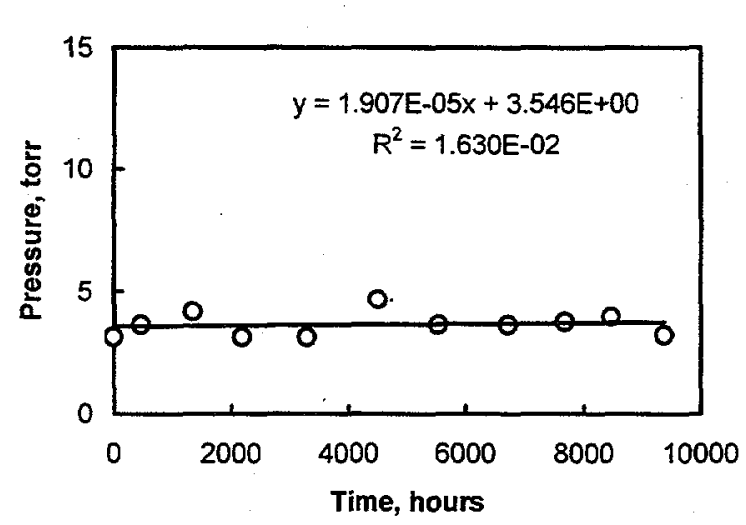


Film:

E 48662-146-2

Panel Set:

E-I

Gas:

Air

$P=a+b t$

\begin{tabular}{|c|c|c|c|c|c|}
\hline Panel & $V, c c$ & $A$, in. $^{2}$ & a & $A^{*}(P a m b-a) / b$ & Permeance \\
\hline$E-I-1$ & 0 & 199.0 & $5.034 \quad 4.846 \mathrm{E}-04$ & $3.203 E+08$ & 0.00004 \\
\hline$E-1-2$ & 7.43 & 195.4 & $2.980 \quad 2.117 \mathrm{E}-04$ & $7.218 E+08$ & 0.00004 \\
\hline$E-1-3$ & 15.27 & 19 & toos & calculate $\mathrm{p}$ & neance. \\
\hline
\end{tabular}

Permeance units $=c c(S T P) / 100$ in. ${ }^{2} \cdot a t m \cdot d a y$

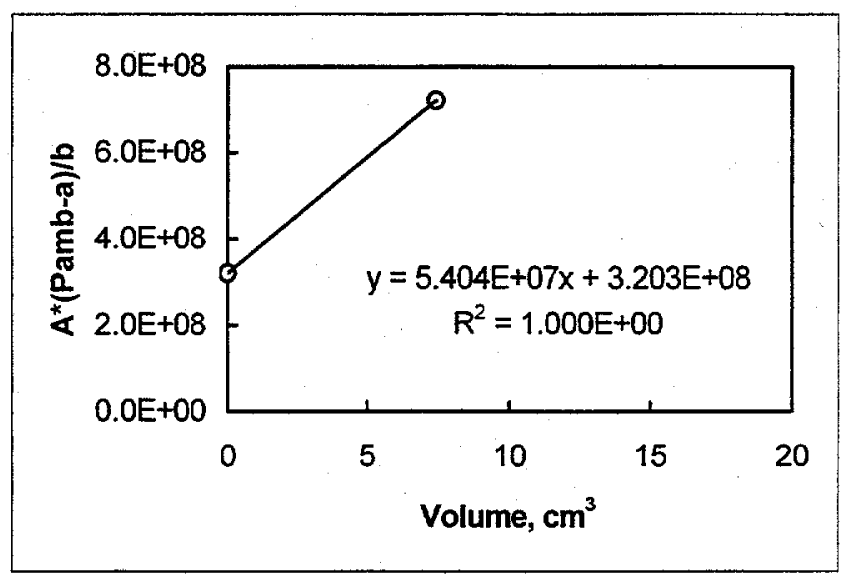

$V_{0}=\quad 5.9 \mathrm{~cm}^{3}$ 
Film:

E 48662-146-2

Panel:

E-1-2

Gas:

Helium

Internal Volume: $\quad 7.43 \mathrm{~cm}^{3}$

$\begin{array}{rrrr}\text { Date } & \text { Time } & \text { Hours } & P \text {, torr } \\ 8 / 7 / 97 & 2: 00 \mathrm{PM} & 0 & 5.2 \\ 8 / 11 / 97 & 8: 45 \mathrm{AM} & 90.8 & 13.6 \\ 8 / 16 / 97 & 1: 55 \mathrm{PM} & 215.5 & 28.6 \\ 8 / 22 / 97 & 10: 45 \mathrm{AM} & 356 & 46.0 \\ 9 / 2 / 97 & 8: 50 \mathrm{AM} & 617.8 & 75.4 \\ 9 / 13 / 97 & 1: 15 \mathrm{PM} & 885.8 & 104.1\end{array}$
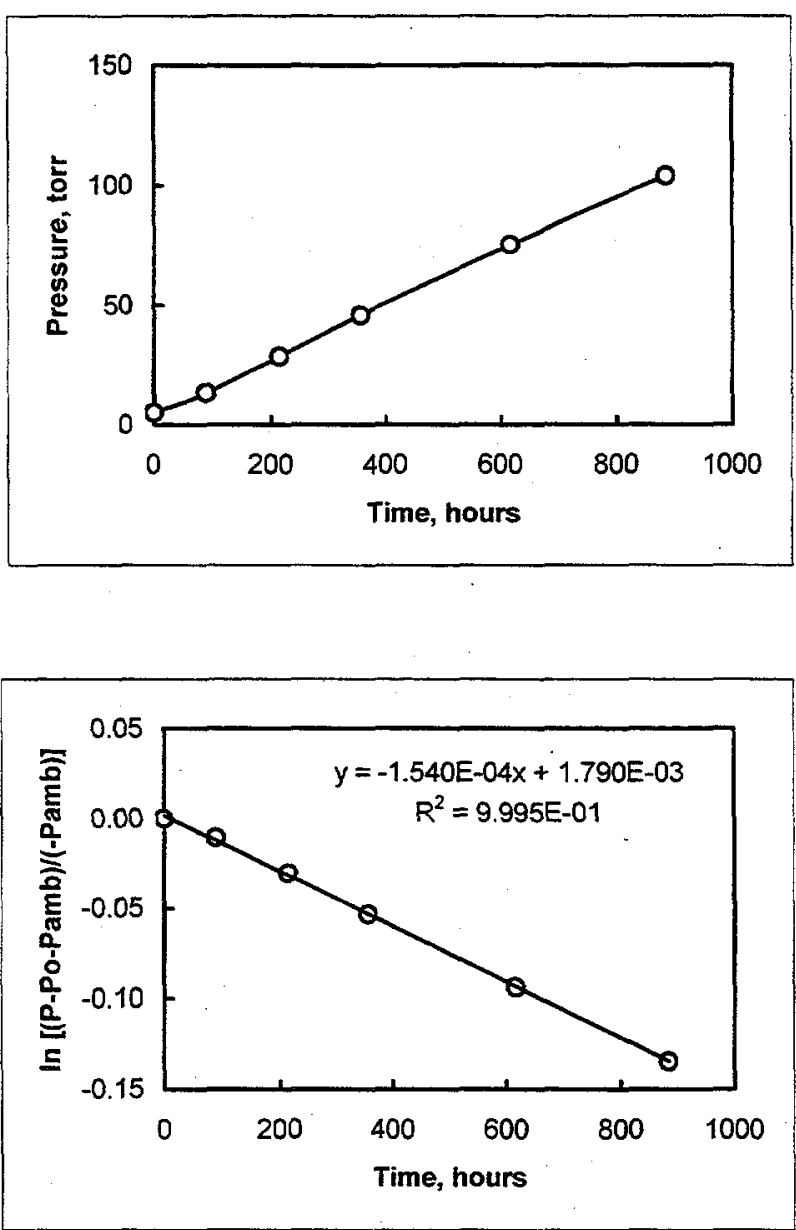
Film:

E 48662-146-2

Panel:

\section{E-I-3}

Gas:

Helium

Internal Volume: $\quad 15.27 \mathrm{~cm}^{3}$

$\begin{array}{rrrr}\text { Date } & \text { Time } & \text { Hours } & \text { P, torr } \\ 8 / 7 / 97 & 2: 00 \mathrm{PM} & 0 & 3.2 \\ 8 / 11 / 97 & 8: 45 \mathrm{AM} & 90.8 & 8.3 \\ 8 / 16 / 97 & 1: 55 \mathrm{PM} & 215.5 & 17.8 \\ 8 / 22 / 97 & 10: 45 \mathrm{AM} & 356 & 28.1 \\ 9 / 2 / 97 & 8: 50 \mathrm{AM} & 617.8 & 46.5\end{array}$
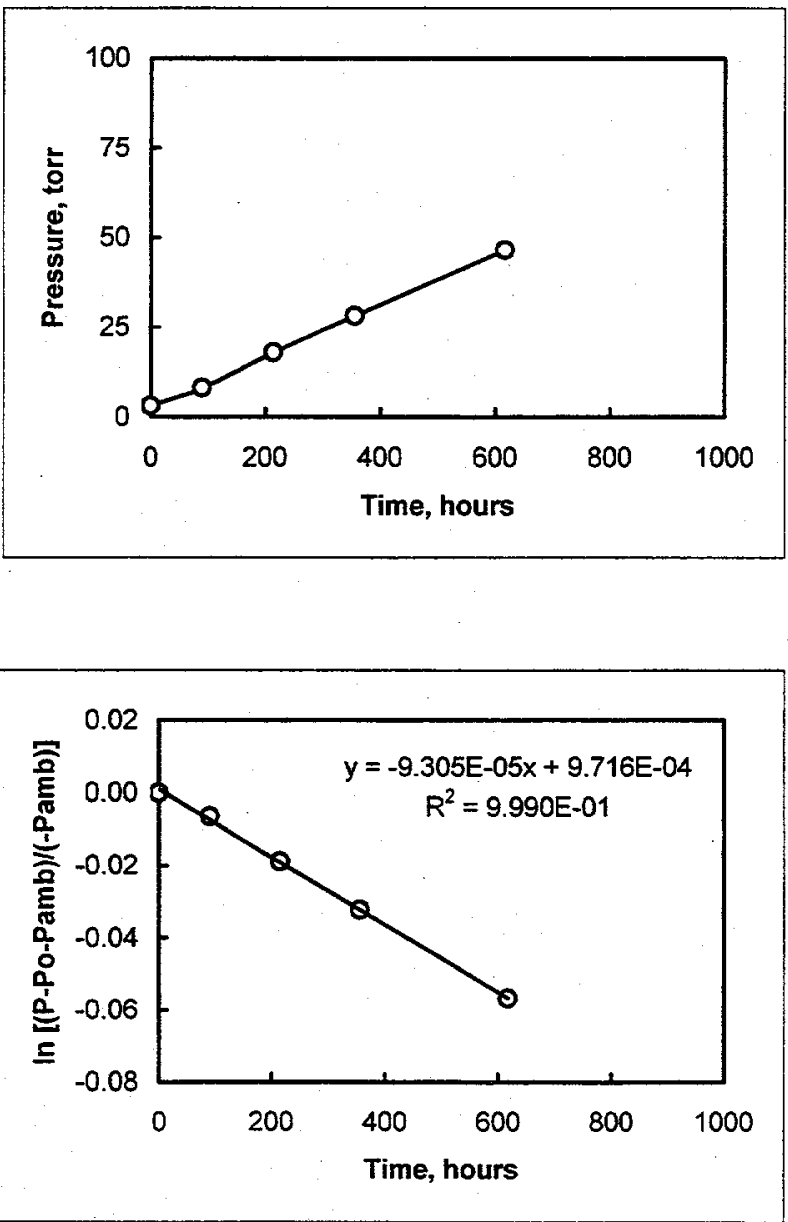
Film:

E 48662-146-2

Panel Set:

E-1

Gas:

Helium

$P=P o+P a m b[1-\exp (-b t)]$

Panel

$\mathrm{V}, \mathrm{cc}$

$A$, in. ${ }^{2}$

b

$\mathrm{A} / \mathrm{b}$ Permeance

E-I-2

7.43

195.4 1.540E-04 1.269E+06

0.019

E-I-3

15.27

199.0 9.305E-05 2.139E+06

0.019

Permeance units $=c c($ STP $) / 100$ in. ${ }^{2} \cdot$ atm $•$ day

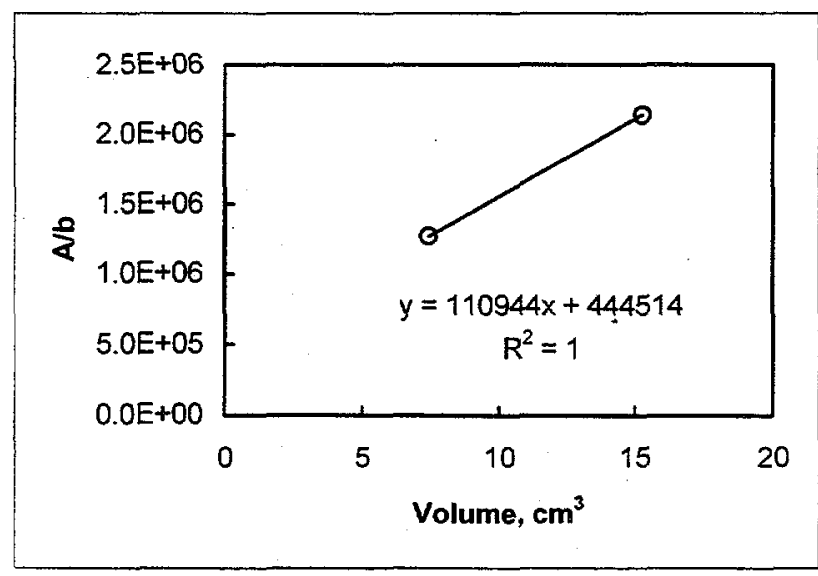

$V_{0}=$

$4.0 \mathrm{~cm}^{3}$ 
Film:

E 48662-146-2

Panel:

E-II-1

Gas:

Air

Internal Volume: $\quad 0 \mathrm{~cm}^{3}$

\begin{tabular}{|c|c|c|c|}
\hline Date & Time & Hours & $P$, torr \\
\hline $1 / 22 / 97$ & 11:30 AM & 0 & 4.7 \\
\hline 2/28/97 & $10: 00 \mathrm{AM}$ & 886.5 & 6.4 \\
\hline 4/18/97 & $10: 45$ AM & 2063.25 & 6.8 \\
\hline $5 / 28 / 97$ & $10: 00 \mathrm{AM}$ & 3022.5 & 7.6 \\
\hline $6 / 30 / 97$ & $9: 30$ AM & 3814 & 7.8 \\
\hline $8 / 7 / 98$ & $8: 45$ AM & 4725.2 & $8: 6$ \\
\hline $9 / 3 / 97$ & $10: 00 \mathrm{AM}$ & 5374.4 & 8.3 \\
\hline 10/17/97 & $10: 00 \mathrm{AM}$ & 6430.4 & 7.8 \\
\hline $11 / 25 / 97$ & $9: 15 \mathrm{AM}$ & 7365.65 & 7.8 \\
\hline $1 / 7 / 98$ & $9: 15$ AM & 8398 & 8.8 \\
\hline $2 / 17 / 98$ & 10:00 AM & 9382 & 8.8 \\
\hline $3 / 17 / 98$ & 2:00 PM & 10054 & 8.4 \\
\hline $4 / 24 / 98$ & 10:00 AM & 10966 & 8.8 \\
\hline $6 / 4 / 98$ & $9: 00 \mathrm{AM}$ & 11950 & 9.9 \\
\hline $7 / 24 / 98$ & $8: 30 \mathrm{AM}$ & 13150 & 10.5 \\
\hline $8 / 24 / 98$ & 1:15 PM & 13894 & 10.1 \\
\hline $9 / 25 / 98$ & $9: 30 \mathrm{AM}$ & 14662 & 9.9 \\
\hline $10 / 23 / 98$ & 1:30 PM & 15334 & 9.9 \\
\hline $12 / 31 / 98$ & $8: 30 \mathrm{AM}$ & 16990 & 9.9 \\
\hline $2 / 15 / 99$ & $10: 00 \mathrm{AM}$ & 18094 & 9.9 \\
\hline $3 / 16 / 99$ & $9: 00 \mathrm{AM}$ & 18790 & 10.5 \\
\hline $4 / 30 / 99$ & $9: 15 \mathrm{AM}$ & 19870 & 10.9 \\
\hline $6 / 7 / 99$ & $10: 00 \mathrm{AM}$ & 20782 & 11.0 \\
\hline $7 / 16 / 99$ & 1:30 PM & 21718 & 12.1 \\
\hline $8 / 17 / 99$ & $10: 30 \mathrm{AM}$ & 22486 & 11.6 \\
\hline $10 / 14 / 99$ & $11: 30 \mathrm{AM}$ & 23878 & 11.8 \\
\hline
\end{tabular}

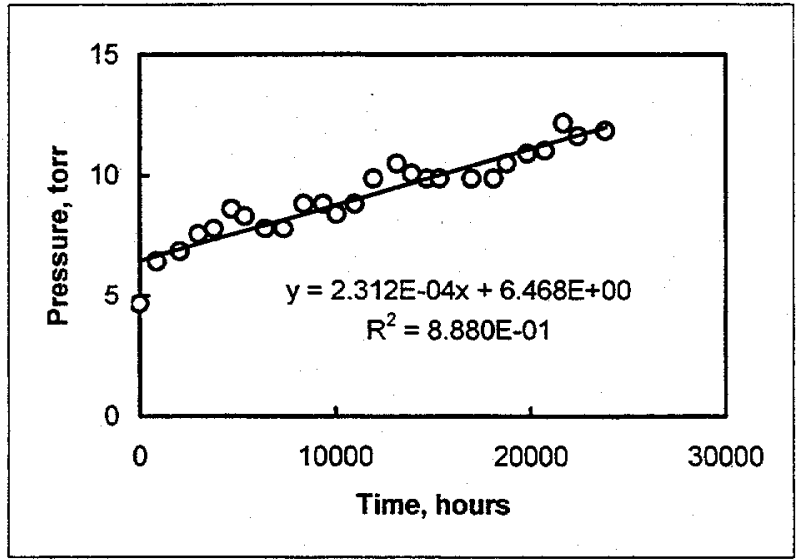


Film:

E 48662-146-2

Panel:

E-II-2

Gas:

Air

Internal Volume: $\quad 7.47 \mathrm{~cm}^{3}$

$\begin{array}{rrrr}\text { Date } & \text { Time } & \text { Hours } & P \text {, torr } \\ 1 / 22 / 97 & 11: 30 \mathrm{AM} & 0 & 5.2 \\ 2 / 28 / 97 & 10: 00 \mathrm{AM} & 886.5 & 3.3 \\ 4 / 18 / 97 & 10: 45 \mathrm{AM} & 2063.25 & 4.3 \\ 5 / 28 / 97 & 10: 00 \mathrm{AM} & 3022.5 & 4.0 \\ 6 / 30 / 97 & 9: 30 \mathrm{AM} & 3814 & 4.5 \\ 8 / 7 / 98 & 8: 45 \mathrm{AM} & 4725.2 & 4.7 \\ 9 / 3 / 97 & 10: 00 \mathrm{AM} & 5374.4 & 4.7 \\ 10 / 17 / 97 & 10: 00 \mathrm{AM} & 6430.4 & 4.2 \\ 11 / 25 / 97 & 9: 15 \mathrm{AM} & 7365.65 & 4.6 \\ 1 / 7 / 98 & 9: 15 \mathrm{AM} & 8398 & 5.2 \\ 2 / 17 / 98 & 10: 00 \mathrm{AM} & 9382 & 5.2 \\ 3 / 17 / 98 & 2: 00 \mathrm{PM} & 10054 & 5.3 \\ 4 / 24 / 98 & 10: 00 \mathrm{AM} & 10966 & 4.9 \\ 6 / 4 / 98 & 9: 00 \mathrm{AM} & 11950 & 5.9 \\ 7 / 24 / 98 & 8: 30 \mathrm{AM} & 13150 & 5.5\end{array}$

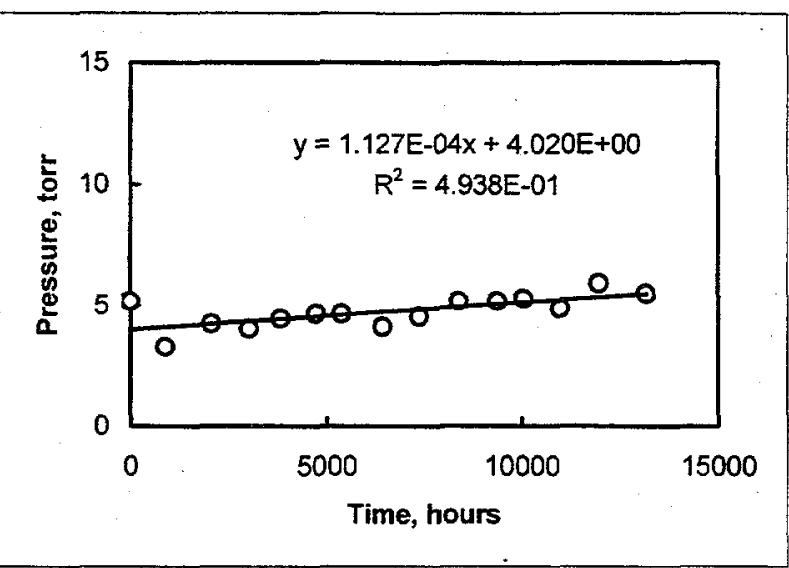


Film:

E 48662-146-2

Panel Set:

E-II

Gas:

Air

$P=a+b t$

$\begin{array}{lrrrrrr}\text { Panel } & \text { V, cc } & \text { A, in. }{ }^{2} & a & \text { b } & A^{*} \text { (Pamb-a)/b Permeance } \\ \text { E-II-1 } & 0 & 196.4 & 6.468 & 2.312 E-04 & 6.613 E+08 & 0.00002 \\ \text { E-II-2 } & 7.43 & 198.4 & 4.020 & 1.127 E-04 & 1.375 E+09 & 0.00002\end{array}$

Permeance units $=c c($ STP $) / 100$ in. $^{2} \cdot$ atm $\bullet$ day

Vo assumed to be $5 \mathrm{~cm}^{3}$ 
Film:

Panel:

E 48662-146-2

Gas:

E-III-1

Internal Volume: $\quad 0 \mathrm{~cm}^{3}$

$\begin{array}{rrrr}\text { Date } & \text { Time } & \text { Hours } & \text { P, torr } \\ 2 / 11 / 97 & 8: 15 \text { AM } & 0 & 5.7 \\ 2 / 13 / 97 & 8: 30 \text { AM } & 48.25 & 27.2 \\ 2 / 14 / 97 & 8: 30 \text { AM } & 71.75 & 37.4 \\ 2 / 15 / 97 & 12: 40 \text { PM } & 99.42 & 48.9 \\ 2 / 17 / 97 & 8: 35 \text { AM } & 142.84 & 67.8 \\ 2 / 19 / 97 & 10: 00 \text { AM } & 191.76 & 87.3 \\ 2 / 21 / 97 & 8: 30 \text { AM } & 237.76 & 104.9 \\ 2 / 25 / 97 & 9: 00 \text { AM } & 334.09 & 139.2\end{array}$
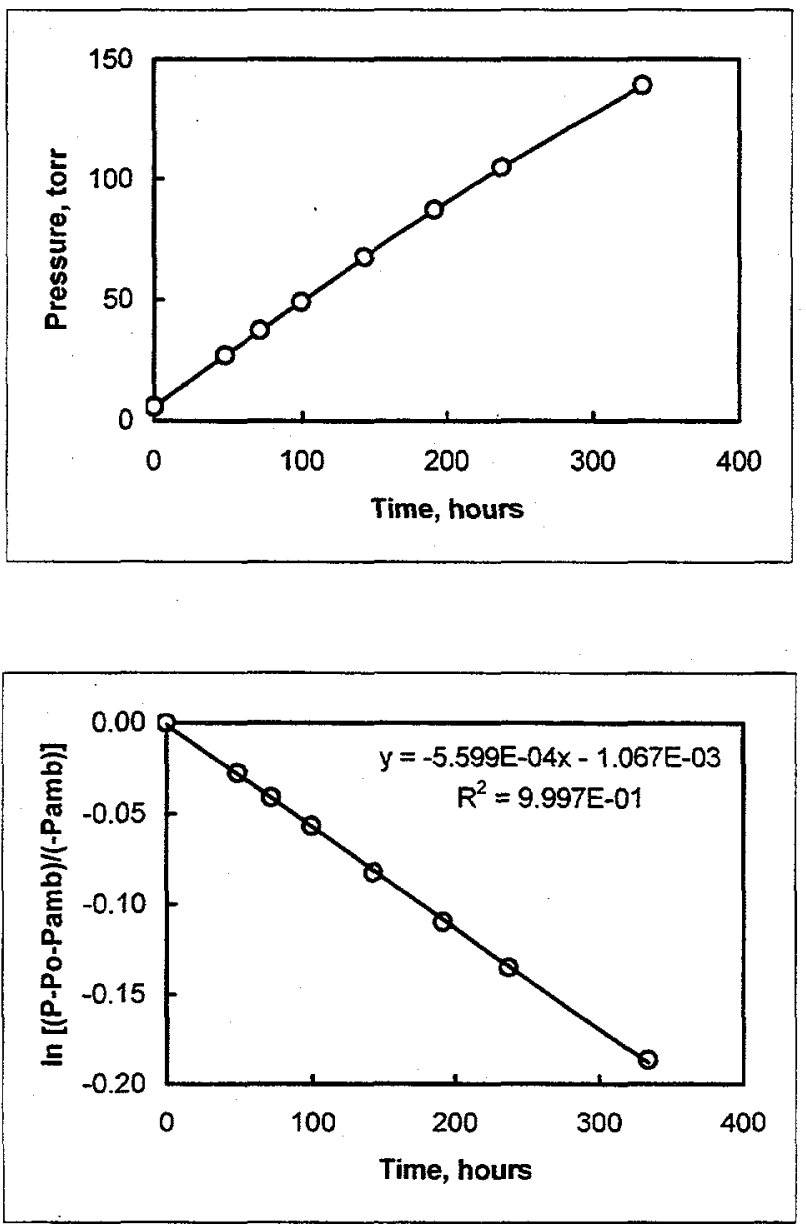
Film:

E 48662-1.46-2

Panel:

E-III-3

Gas:

Helium

Internal Volume:

$15.24 \mathrm{~cm}^{3}$

$\begin{array}{rrrr}\text { Date } & \text { Time } & \text { Hours } & \mathrm{P} \text {, torr } \\ 2 / 11 / 97 & 8: 15 \mathrm{AM} & 0 & 5.5 \\ 2 / 13 / 97 & 8: 30 \mathrm{AM} & 48.25 & 7.0 \\ 2 / 14 / 97 & 8: 30 \mathrm{AM} & 71.75 & 10.1 \\ 2 / 15 / 97 & 12: 40 \mathrm{PM} & 99.42 & 12.5 \\ 2 / 17 / 97 & 8: 35 \mathrm{AM} & 142.84 & 17.3 \\ 2 / 19 / 97 & 10: 00 \mathrm{AM} & 191.76 & 23.1 \\ 2 / 21 / 97 & 8: 30 \mathrm{AM} & 237.76 & 29.9 \\ 2 / 25 / 97 & 9: 00 \mathrm{AM} & 334.09 & 37.6 \\ 3 / 7 / 97 & 11: 00 \mathrm{AM} & 575.26 & 63.2 \\ 3 / 19 / 97 & 9: 10 \mathrm{AM} & 861.43 & 97.2\end{array}$
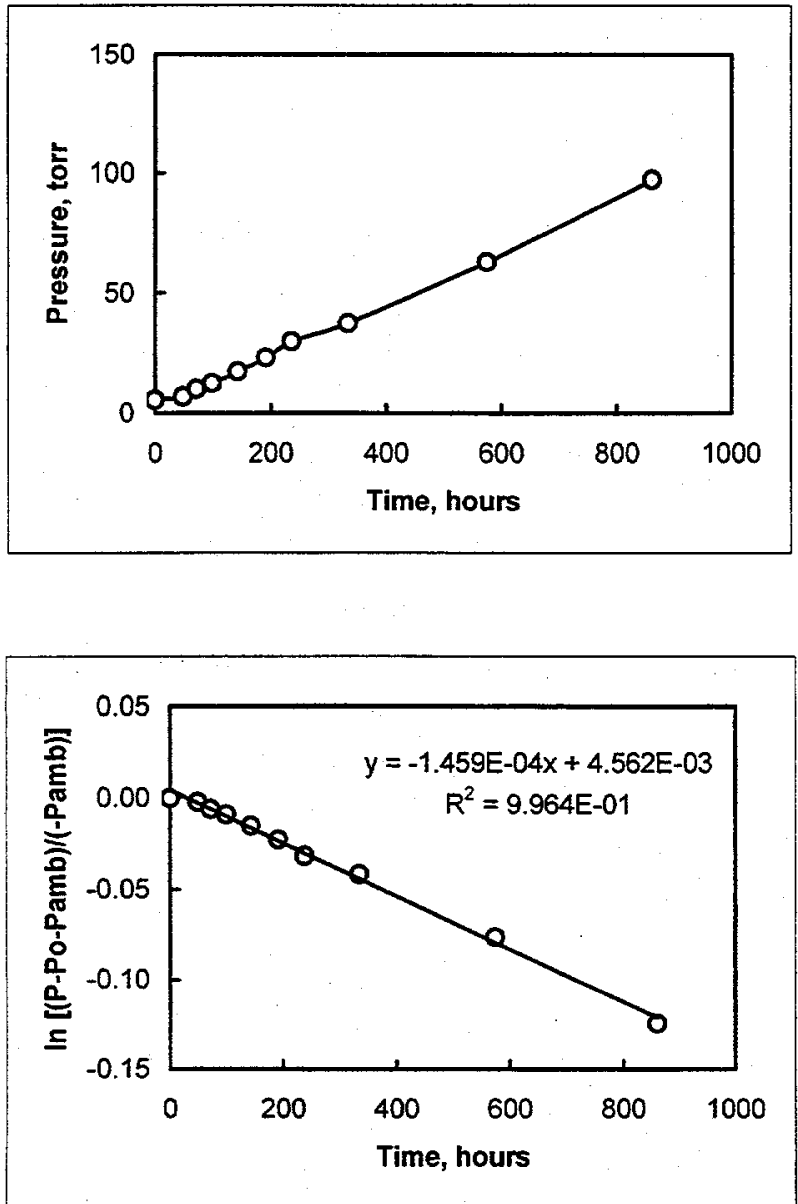
Film:

E 48662-146-2

Panel Set:

E-III

Gas:

Helium

$P=P o+P a m b[1-\exp (-b t)]$

Panel

$\mathrm{V}, \mathrm{cc}$

$A$, in. ${ }^{2}$

b

A/b Permeance

E-III-1

198.0 5.599E-04 3.536E+05

0.033

E-III-3

15.24

$198.01 .459 \mathrm{E}-04$

1.357E+06

0.033

Permeance units $=c c($ STP $) / 100$ in..$^{2} \cdot$ atm $\cdot$ day

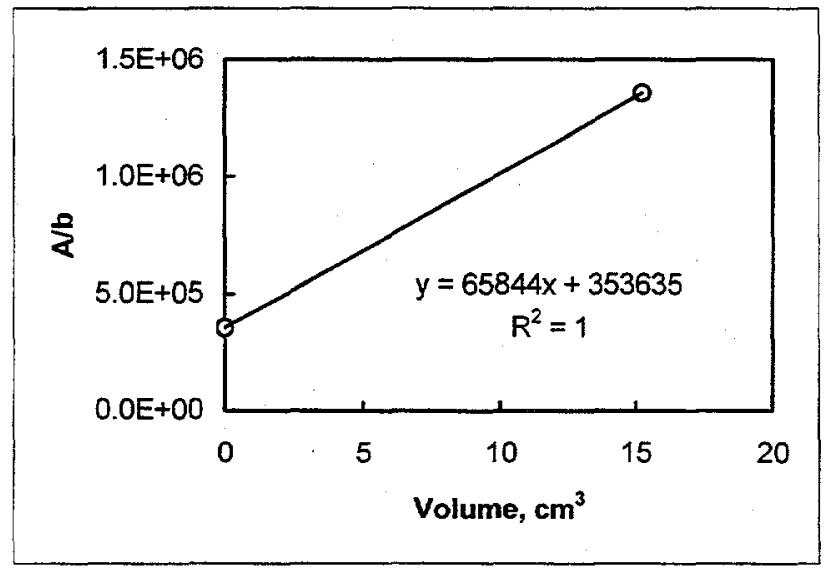

Vo $=$

$5.4 \mathrm{~cm}^{3}$ 
Film:

E 48662-153-1

Panel:

F-l-1

Gas:

Air

Internal Volume: $\quad 0 \mathrm{~cm}^{3}$

$\begin{array}{rrrr}\text { Date } & \text { Time } & \text { Hours } & P, \text { torr } \\ 5 / 28 / 97 & 10: 00 \mathrm{AM} & 0 & 3.3 \\ 6 / 30 / 97 & 9: 30 \mathrm{AM} & 791.5 & 7.3 \\ 8 / 7 / 98 & 8: 45 \mathrm{AM} & 1702.7 & 9.0 \\ 9 / 3 / 97 & 10: 00 \mathrm{AM} & 2352 & 10.4 \\ 10 / 17 / 97 & 10: 00 \mathrm{AM} & 3408 & 11.4\end{array}$

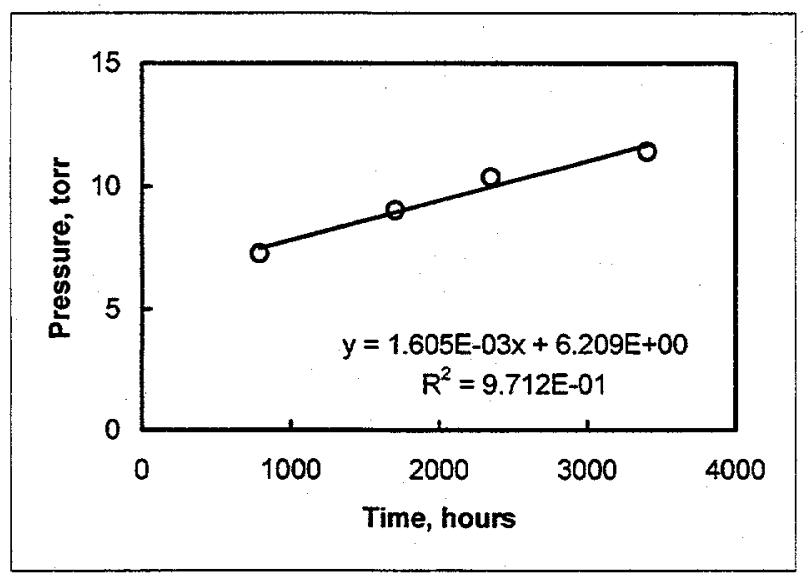

Note: data point at $t=0$ deleted from plot and regression 
$\begin{array}{ll}\text { Film: } & \text { E 48662-153-1 } \\ \text { Panel: } & \text { F-I-2 } \\ \text { Gas: } & \text { Air } \\ \text { Internal Volume: } & 7.43 \mathrm{~cm}^{3}\end{array}$

$\begin{array}{rrrr}\text { Date } & \text { Time } & \text { Hours } & \text { P, torr } \\ 5 / 28 / 97 & 10: 00 \mathrm{AM} & 0 & 3.1 \\ 6 / 30 / 97 & 9: 30 \mathrm{AM} & 791.5 & 6.8 \\ 8 / 7 / 98 & 8: 45 \mathrm{AM} & 1702.7 & 10.4 \\ 9 / 3 / 97 & 10: 00 \mathrm{AM} & 2352 & 13.0 \\ 10 / 17 / 97 & 10: 00 \mathrm{AM} & 3408 & 15.7 \\ 11 / 25 / 97 & 9: 15 \mathrm{AM} & 4343.25 & 17.7 \\ 1 / 7 / 98 & 9: 15 \mathrm{AM} & 5375 & 21.0 \\ 2 / 17 / 98 & 10: 00 \mathrm{AM} & 6359 & 23.2 \\ 3 / 17 / 98 & 2: 00 \mathrm{PM} & 7031 & 24.4 \\ 4 / 24 / 98 & 10: 00 \mathrm{AM} & 7943 & 27.3 \\ 6 / 4 / 98 & 9: 00 \mathrm{AM} & 8927 & 29.9 \\ 7 / 24 / 98 & 8: 30 \mathrm{AM} & 10127 & 32.7 \\ 8 / 24 / 98 & 1: 15 \mathrm{PM} & 10871 & 34.8 \\ 9 / 25 / 98 & 9: 30 \mathrm{AM} & 11639 & 36.3 \\ 10 / 23 / 98 & 1: 30 \mathrm{PM} & 12311 & 37.0 \\ 12 / 31 / 98 & 8: 30 \mathrm{AM} & 13967 & 40.2 \\ 2 / 15 / 99 & 10: 00 \mathrm{AM} & 15071 & 43.1 \\ 3 / 16 / 99 & 9: 00 \mathrm{AM} & 15767 & 44.2 \\ 4 / 30 / 99 & 9: 15 \mathrm{AM} & 16847 & 47.5 \\ 6 / 7 / 99 & 10: 00 \mathrm{AM} & 17759 & 48.8\end{array}$

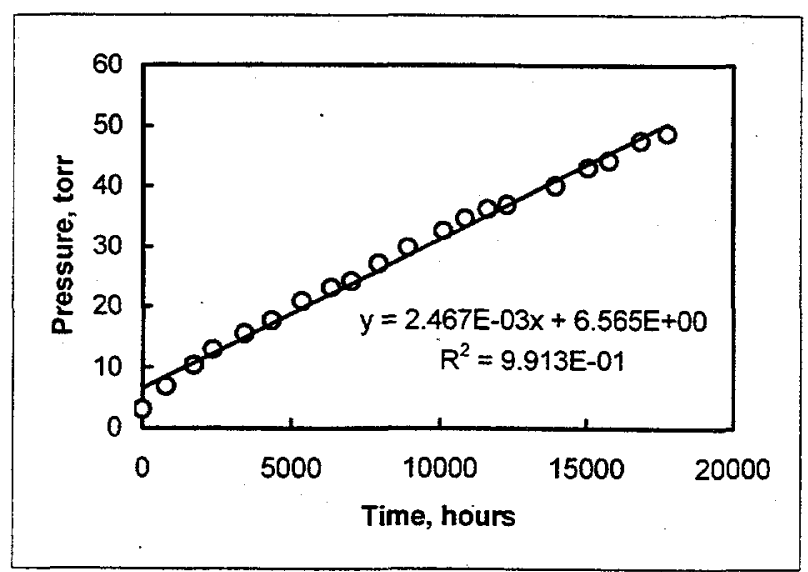


Film: $\quad$ E 48662-153-1

Panel: F-l-3

Gas: Air

Internal Volume: $\quad 15.27 \mathrm{~cm}^{3}$

$\begin{array}{rrrr}\text { Date } & \text { Time } & \text { Hours } & P, \text { torr } \\ 5 / 28 / 97 & 10: 00 \mathrm{AM} & 0 & 3.1 \\ 6 / 30 / 97 & 9: 30 \mathrm{AM} & 791.5 & 3.1 \\ 8 / 7 / 98 & 8: 45 \mathrm{AM} & 1702.7 & 4.2 \\ 9 / 3 / 97 & 10: 00 \mathrm{AM} & 2352 & 3.6 \\ 10 / 17 / 97 & 10: 00 \mathrm{AM} & 3408 & 4.4 \\ 11 / 25 / 97 & 9: 15 \mathrm{AM} & 4343.25 & 4.6 \\ 1 / 7 / 98 & 9: 15 \mathrm{AM} & 5375 & 5.2 \\ 2 / 17 / 98 & 10: 00 \mathrm{AM} & 6359 & 5.3 \\ 3 / 17 / 98 & 2: 00 \mathrm{PM} & 7031 & 5.5 \\ 4 / 24 / 98 & 10: 00 \mathrm{AM} & 7943 & 5.2 \\ 6 / 4 / 98 & 9: 00 \mathrm{AM} & 8927 & 6.2 \\ 7 / 24 / 98 & 8: 30 \mathrm{AM} & 10127 & 6.2 \\ 8 / 24 / 98 & 1: 30 \mathrm{PM} & 10871 & 5.9 \\ 9 / 25 / 98 & 9: 30 \mathrm{AM} & 11639 & 6.4 \\ 10 / 23 / 98 & 1: 30 \mathrm{PM} & 12311 & 5.7 \\ 12 / 31 / 98 & 8: 30 \mathrm{AM} & 13967 & 5.5 \\ 2 / 15 / 98 & 10: 00 \mathrm{AM} & 15071 & 5.9\end{array}$

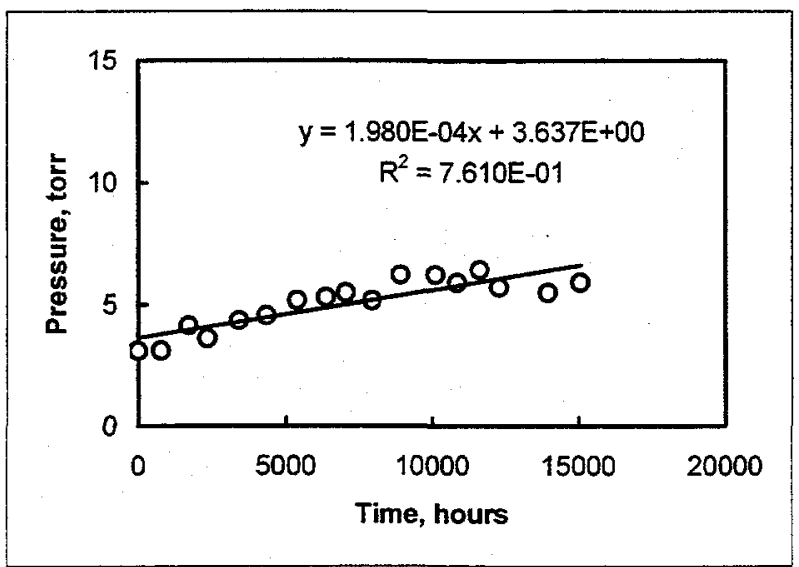


$\begin{array}{ll}\text { Film: } & \text { E 48662-153-1 } \\ \text { Panel Set: } & \text { F-I } \\ \text { Gas: } & \text { Air } \\ & \\ P=a+b t & \end{array}$

\begin{tabular}{|c|c|c|c|c|c|}
\hline Panel & $V, c c$ & $A$, in. $^{2}$ & b & $A^{*}($ Pamb-a)/b & Derm \\
\hline$F-1-1$ & 0 & 200.4 & 6.209 1.605E-03 & $9.724 E+07$ & 0.00011 \\
\hline F-I-2 & 7.43 & 198.4 & 6.565 2.467E-03 & $6.260 E+07$ & 0.00043 \\
\hline$F-1-3$ & 15.27 & 198.4 & 3.637 1.980E-04 & $7.829 E+08$ & 0.00006 \\
\hline
\end{tabular}

Permeance units $=c c($ STP $) / 100$ in. $^{2} \cdot$ atm $\cdot$ day

Vo assumed to be $5 \mathrm{~cm}^{3}$ 
$\begin{array}{ll}\text { Film: } & \text { E 48662-153-1 } \\ \text { Panel: } & \text { F-II-1 } \\ \text { Gas: } & \text { Air } \\ \text { Internal Volume: } & 0 \mathrm{~cm}^{3}\end{array}$

$\begin{array}{rrrr}\text { Date } & \text { Time } & \text { Hours } & P \text {, torr } \\ 8 / 7 / 97 & 8: 45 \text { AM } & 0 & 5.2 \\ 9 / 3 / 97 & 10: 00 \text { AM } & 649.2 & 8.8 \\ 10 / 17 / 97 & 10: 00 \text { AM } & 1705.2 & 10.4 \\ 11 / 25 / 97 & 9: 15 \text { AM } & 2640.45 & 10.2 \\ 1 / 7 / 98 & 9: 15 \text { AM } & 3672.5 & 11.4 \\ 2 / 17 / 98 & 10: 00 \text { AM } & 4656.5 & 12.5 \\ 3 / 17 / 98 & 2: 00 \mathrm{PM} & 5328 & 13.0 \\ 4 / 24 / 98 & 10: 00 \text { AM } & 6240 & 13.5 \\ 6 / 4 / 98 & 10: 00 \text { AM } & 7224 & 14.5 \\ 7 / 24 / 98 & 9: 15 \text { AM } & 8424 & 16.2 \\ 8 / 24 / 98 & 1: 15 \text { PM } & 9168 & 16.8 \\ 9 / 25 / 98 & 9: 30 \text { AM } & 9936 & 16.7 \\ 10 / 23 / 98 & 1: 30 \mathrm{PM} & 10608 & 16.9 \\ 12 / 31 / 98 & 8: 30 \text { AM } & 12264 & 17.6 \\ 2 / 15 / 98 & 10: 00 \text { AM } & 13368 & 18.7 \\ 3 / 16 / 99 & 9: 00 \text { AM } & 14064 & 19.4 \\ 4 / 30 / 99 & 9: 15 \text { AM } & 15144 & 20.4 \\ 6 / 7 / 99 & 10: 00 \text { AM } & 16056 & 22.1 \\ 7 / 16 / 99 & 1: 30 \text { PM } & 16992 & 22.3 \\ 8 / 17 / 99 & 10: 30 \text { AM } & 17760 & 22.9 \\ 10 / 14 / 99 & 11: 30 \text { AM } & 19152 & 24.0\end{array}$

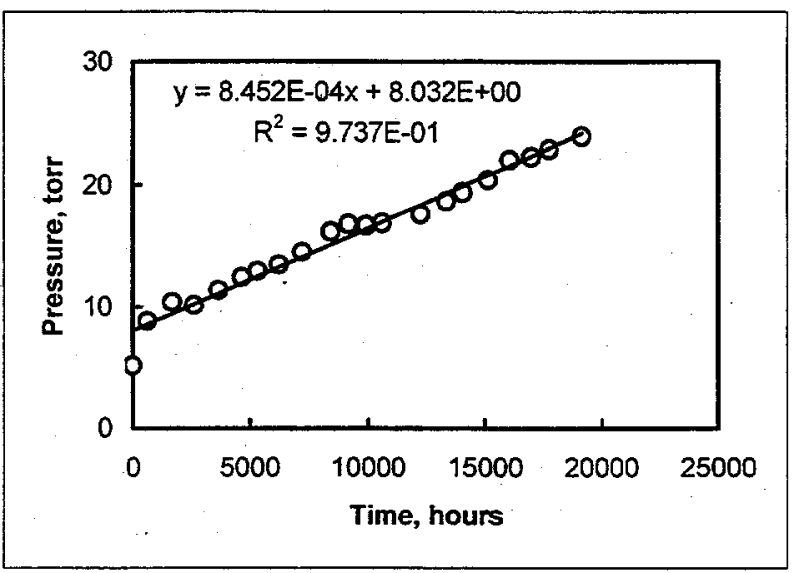


Film:

E 48662-153-1

Panel:

F-1I-2

Gas:

Air

Internal Volume: $\quad 7.66 \mathrm{~cm}^{3}$

$\begin{array}{rrrr}\text { Date } & \text { Time } & \text { Hours } & P, \text { torr } \\ 8 / 7 / 98 & 8: 45 \mathrm{AM} & 0 & 4.5 \\ 9 / 3 / 97 & 10: 00 \mathrm{AM} & 649.2 & 4.2 \\ 10 / 17 / 97 & 10: 00 \mathrm{AM} & 1705.2 & 4.9 \\ 11 / 25 / 97 & 9: 15 \mathrm{AM} & 2640.45 & 4.7 \\ 1 / 7 / 98 & 9: 15 \mathrm{AM} & 3672.5 & 6.2 \\ 2 / 17 / 98 & 10: 00 \mathrm{AM} & 4656.5 & 6.4 \\ 3 / 17 / 98 & 2: 00 \mathrm{PM} & 5328 & 5.7 \\ 4 / 24 / 98 & 10: 00 \mathrm{AM} & 6240 & 6.8 \\ 6 / 4 / 98 & 10: 00 \mathrm{AM} & 7224 & 7.1 \\ 7 / 24 / 98 & 9: 15 \mathrm{AM} & 8424 & 7.3 \\ 8 / 24 / 98 & 1: 15 \mathrm{PM} & 9168 & 8.1 \\ 9 / 25 / 98 & 9: 30 \mathrm{AM} & 9936 & 7.7 \\ 10 / 23 / 98 & 1: 30 \mathrm{PM} & 10608 & 7.9 \\ 12 / 31 / 98 & 8: 30 \mathrm{AM} & 12264 & 8.0 \\ 2 / 15 / 98 & 10: 00 \mathrm{AM} & 13368 & 8.6 \\ 3 / 16 / 99 & 9: 00 \mathrm{AM} & 14064 & 8.5 \\ 4 / 30 / 99 & 9: 15 \mathrm{AM} & 15144 & 10.0 \\ 6 / 7 / 99 & 10: 00 \mathrm{AM} & 16056 & 10.6 \\ 7 / 16 / 99 & 1: 30 \mathrm{PM} & 16992 & 11.2 \\ 8 / 17 / 99 & 10: 30 \mathrm{AM} & 17760 & 10.6 \\ 10 / 14 / 99 & 11: 30 \mathrm{AM} & 19152 & 11.6\end{array}$

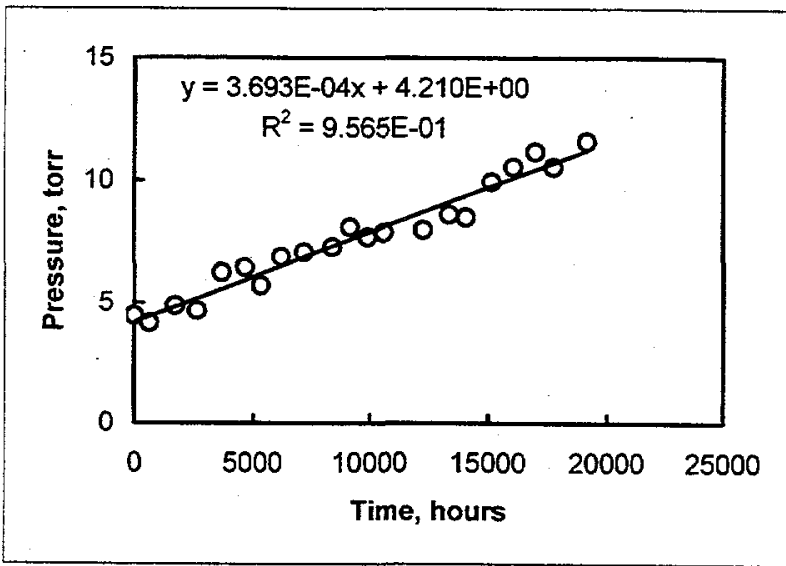


Film:

E 48662-153-1

Panel:

F-II-3

Gas:

Air

Internal Volume: $\quad 15.00 \mathrm{~cm}^{3}$

$\begin{array}{rrrr}\text { Date } & \text { Time } & \text { Hours } & \text { P, torr } \\ 8 / 7 / 98 & 8: 45 \text { AM } & 0 & 3.9 \\ 9 / 3 / 97 & 10: 00 \mathrm{AM} & 649.2 & 5.1 \\ 10 / 17 / 97 & 10: 00 \mathrm{AM} & 1705.2 & 4.2 \\ 11 / 25 / 97 & 9: 15 \mathrm{AM} & 2640.45 & 4.7 \\ 1 / 7 / 98 & 9: 15 \mathrm{AM} & 3672.5 & 4.9 \\ 2 / 17 / 98 & 10: 00 \mathrm{AM} & 4656.5 & 6.8 \\ 3 / 17 / 98 & 2: 00 \mathrm{PM} & 5328 & 6.7 \\ 4 / 24 / 98 & 10: 00 \mathrm{AM} & 6240 & 5.2 \\ 6 / 4 / 98 & 10: 00 \mathrm{AM} & 7224 & 4.8 \\ 7 / 24 / 98 & 9: 15 \mathrm{AM} & 8424 & 7.5 \\ 8 / 24 / 98 & 1: 15 \mathrm{PM} & 9168 & 5.7 \\ 9 / 25 / 98 & 9: 30 \mathrm{AM} & 9936 & 6.2 \\ 10 / 23 / 98 & 1: 30 \mathrm{PM} & 10608 & 7.6 \\ 12 / 31 / 98 & 8: 30 \mathrm{AM} & 12264 & 6.7 \\ 2 / 15 / 98 & 10: 00 \mathrm{AM} & 13368 & 8.1 \\ 3 / 16 / 99 & 9: 00 \mathrm{AM} & 14064 & 7.3 \\ 4 / 30 / 99 & 9: 15 \mathrm{AM} & 15144 & 8.9 \\ 6 / 7 / 99 & 10: 00 \mathrm{AM} & 16056 & 8.0 \\ 7 / 16 / 99 & 1: 30 \mathrm{PM} & 16992 & 10.2 \\ 8 / 17 / 99 & 10: 30 \mathrm{AM} & 17760 & 8.8 \\ 10 / 14 / 99 & 11: 30 \mathrm{AM} & 19152 & 10.1\end{array}$

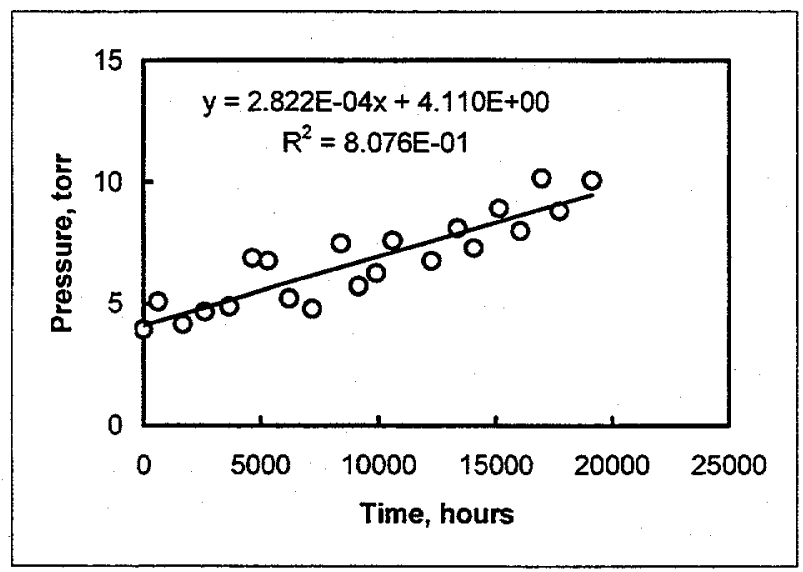


Film:

Panel Set:

E 48662-153-1

Gas:

F-II

Air

$P=a+b t$

Panel

F-II-1

V, cc

A, in. ${ }^{2}$

a

b

$A^{*}($ Pamb-a $) / b$ Permeance

F-II-2

7.66

198.4

8.032 8.452E-04

$\begin{array}{ll}1.824 E+08 & 0.00010\end{array}$

F-II-3

15.00

198.4

4.210 3.693E-04

4.110 2.822E-04

$4.216 \mathrm{E}+08$

$5.490 \mathrm{E}+08$

0.00008

Permeance units $=c c($ STP $) / 100$ in. $^{2} \cdot$ atm $\cdot$ day

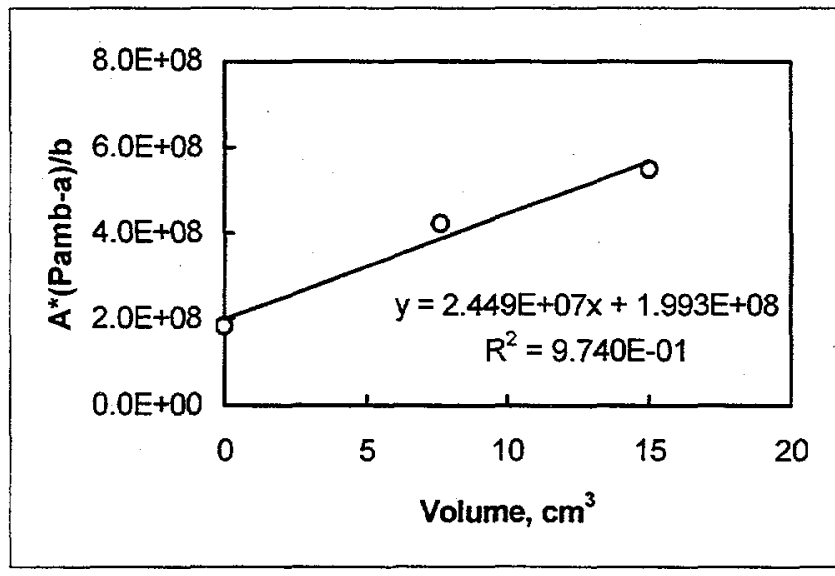

$V_{0}=$

$8.1 \mathrm{~cm}^{3}$ 
Film:

E 48662-153-1

Panel:

Gas:

F-III-1

Internal Volume: $\quad 0 \mathrm{~cm}^{3}$

$\begin{array}{rrrr}\text { Date } & \text { Time } & \text { Hours } & \text { P, torr } \\ 9 / 3 / 97 & 10: 00 \mathrm{AM} & 0 & 3.8 \\ 10 / 17 / 97 & 10: 00 \mathrm{AM} & 1056 & 8.9 \\ 11 / 25 / 97 & 9: 15 \mathrm{AM} & 1991.25 & 9.0 \\ 1 / 7 / 98 & 9: 15 \mathrm{AM} & 3023 & 10.7 \\ 2 / 17 / 98 & 10: 00 \mathrm{AM} & 4007 & 11.4 \\ 3 / 17 / 98 & 2: 00 \mathrm{PM} & 4679 & 11.8 \\ 4 / 24 / 98 & 10: 00 \mathrm{AM} & 5591 & 12.9\end{array}$

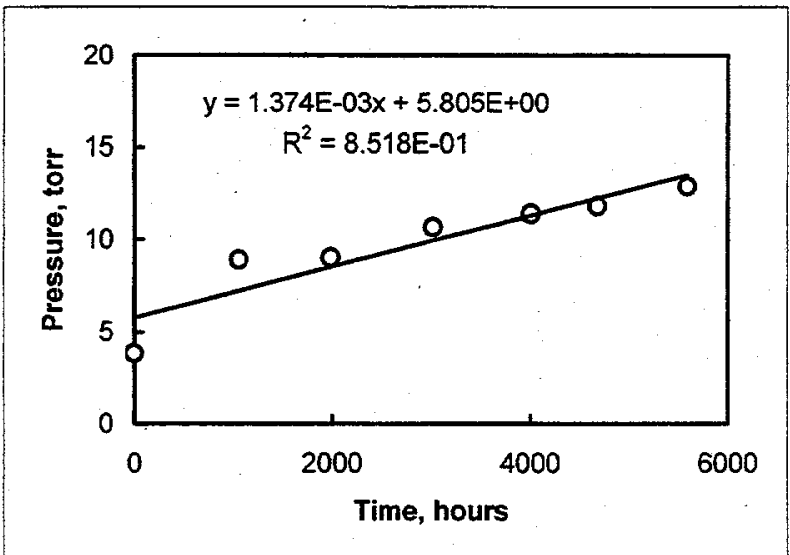


Film:

Panel:

E 48662-153-1

Gas:

F-III-2

Internal Volume: $\quad 7.69 \mathrm{~cm}^{3}$

$\begin{array}{rrrr}\text { Date } & \text { Time } & \text { Hours } & \text { P, torr } \\ \text { 10/21/97 } & 9: 00 \text { AM } & 0 & 4.2 \\ 11 / 25 / 97 & 9: 15 \text { AM } & 840.25 & 3.5\end{array}$




$\begin{array}{ll}\text { Film: } & \text { E 48662-153-1 } \\ \text { Panel: } & \text { F-lll-3 } \\ \text { Gas: } & \text { Air } \\ \text { Internal Volume: } & 14.76 \mathrm{~cm}^{3}\end{array}$

\begin{tabular}{|c|c|c|c|}
\hline Date & Time & Hours & orr \\
\hline $9 / 3 / 97$ & $10: 00 \mathrm{AM}$ & 0 & 3 \\
\hline $10 / 17 / 97$ & $10: 00 \mathrm{AM}$ & 1056 & 3. \\
\hline $11 / 25 / 97$ & $9: 15$ AM & 1991.25 & 3 \\
\hline $1 / 7 / 98$ & $9: 15$ AM & 3023 & 4. \\
\hline 2/17/98 & $10: 00 \mathrm{AM}$ & 4007 & 5.0 \\
\hline $3 / 17 / 98$ & 2:00 PM & 4679 & \\
\hline $4 / 24 / 98$ & $10: 00 \mathrm{AM}$ & 5591 & 5.2 \\
\hline $6 / 4 / 98$ & $10: 00 \mathrm{AM}$ & 6575 & 5.6 \\
\hline $7 / 24 / 98$ & $9: 15 \mathrm{AM}$ & 7775 & 6. \\
\hline $8 / 24 / 98$ & 2:00 PM & 8519 & 7.6 \\
\hline 9/25/98 & 2:00 PM. & 9287 & 6.6 \\
\hline $10 / 23 / 98$ & 2:30 PM & 9959 & 6.3 \\
\hline $12 / 31 / 98$ & $8: 30 \mathrm{AM}$ & 11615 & 6.7 \\
\hline 2/15/99 & $10: 00 \mathrm{AM}$ & 12719 & 7.3 \\
\hline $3 / 16 / 99$ & $10: 00 \mathrm{AM}$ & 13415 & 7.3 \\
\hline 4/30/99 & $9: 15$ AM & 14495 & 7.6 \\
\hline $6 / 7 / 99$ & $10: 00 \mathrm{AM}$ & 15407 & 8.4 \\
\hline 7/16/99 & 1:30 PM & 16343 & 9.1 \\
\hline $8 / 17 / 99$ & $10: 30 \mathrm{AM}$ & 17111 & 8.5 \\
\hline $10 / 1$ & .3 & 18503 & \\
\hline
\end{tabular}

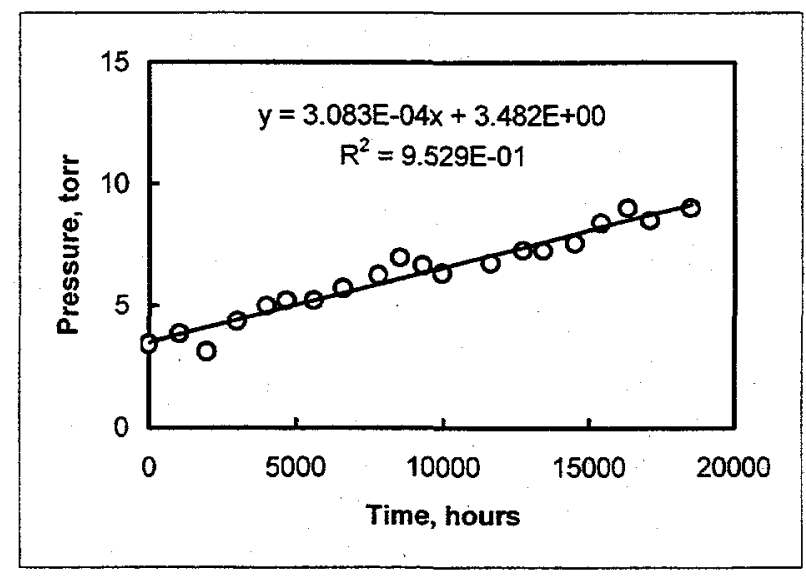


Film:

E 48662-153-1

Panel Set: .

F-III

Gas:

Air

$P=a+b t$

Panel

V, cc

A, in. ${ }^{2}$

a

b $A^{*}($ Pamb-a)/b Permeance

F-III-1

F-III-2 200.0

5.805 1.374E-03

$1.134 E+08 \quad 0.00008$

F-III-3

$$
7.69
$$
198.8

14.76

198.0

3.482 3.083E-04

5.019E+08 0.00008

Permeance units $=c c(S T P) / 100$ in. $^{2} \cdot$ atm $\cdot$ day

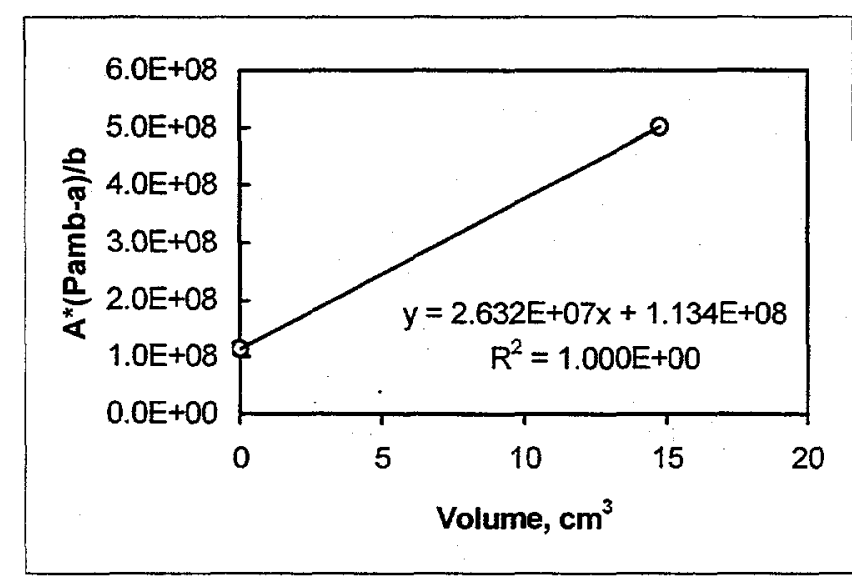
$V_{0}=$
$4.3 \mathrm{~cm}^{3}$ 
Film:

E 48662-153-1

Panel:

F-IV-1

Gas:

Air

Internal Volume: $\quad 0 \mathrm{~cm}^{3}$

$\begin{array}{rrrr}\text { Date } & \text { Time } & \text { Hours } & \text { P, torr } \\ 1 / 7 / 98 & 9: 15 \text { AM } & 0 & 5.2 \\ 2 / 17 / 98 & 10: 00 \mathrm{AM} & 984 & 7.3 \\ 3 / 17 / 98 & 2: 00 \mathrm{PM} & 1656 & 7.8 \\ 4 / 24 / 98 & 10: 00 \mathrm{AM} & 2568 & 9.3 \\ 6 / 4 / 98 & 10: 00 \mathrm{AM} & 3552 & 9.9 \\ 7 / 24 / 98 & 9: 45 \mathrm{AM} & 4752 & 11.9 \\ 8 / 24 / 98 & 2: 00 \mathrm{PM} & 5496 & 13.5 \\ 9 / 25 / 98 & 2: 00 \mathrm{PM} & 6264 & 12.7 \\ 10 / 23 / 98 & 2: 30 \mathrm{PM} & 6936 & 13.2 \\ 12 / 31 / 98 & 8: 30 \mathrm{AM} & 8592 & 14.3 \\ 2 / 15 / 99 & 10: 00 \mathrm{AM} & 9696 & 15.6 \\ 3 / 16 / 99 & 10: 00 \mathrm{AM} & 10392 & 17.5 \\ 4 / 30 / 99 & 9: 15 \mathrm{AM} & 11472 & 18.6 \\ 6 / 7 / 99 & 10: 00 \mathrm{AM} & 12384 & 18.8 \\ 7 / 16 / 99 & 2: 00 \mathrm{PM} & 13320 & 20.4 \\ 8 / 17 / 99 & 10: 30 \mathrm{AM} & 14088 & 22.0 \\ 10 / 14 / 99 & 11: 30 \mathrm{AM} & 15480 & 22.8\end{array}$

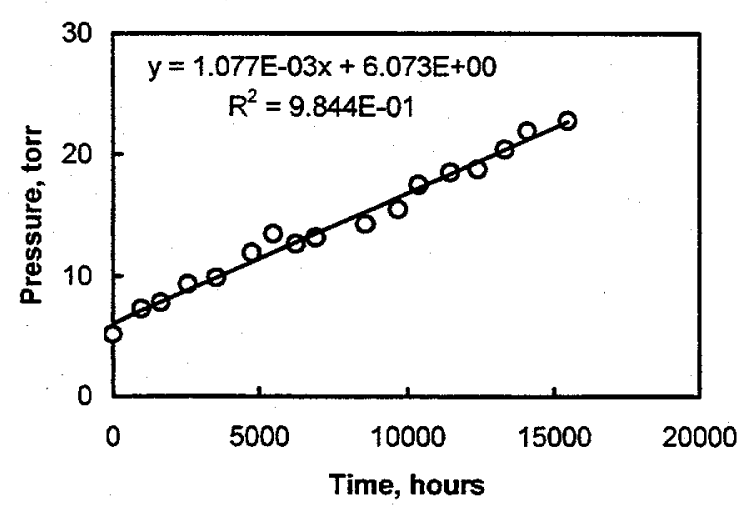


Film:

E 48662-153-1

Panel:

Gas:

F-IV-2

Internal Volume:

Air

$7.43 \mathrm{~cm}^{3}$

$\begin{array}{rrrr}\text { Date } & \text { Time } & \text { Hours } & P \text {, torr } \\ 1 / 7 / 98 & 9: 15 \mathrm{AM} & 0 & 6.0 \\ 2 / 17 / 98 & 10: 00 \mathrm{AM} & 984 & 3.5 \\ 3 / 17 / 98 & 2: 00 \mathrm{PM} & 1656 & 3.8 \\ 4 / 24 / 98 & 10: 00 \mathrm{AM} & 2568 & 4.7 \\ 6 / 4 / 98 & 10: 00 \mathrm{AM} & 3552 & 5.4 \\ 7 / 24 / 98 & 9: 45 \mathrm{AM} & 4752 & 5.7 \\ 8 / 24 / 98 & 2: 00 \mathrm{PM} & 5496 & 6.4 \\ 9 / 25 / 98 & 2: 00 \mathrm{PM} & 6264 & 5.7 \\ 10 / 23 / 98 & 2: 30 \mathrm{PM} & 6936 & 6.0 \\ 12 / 31 / 98 & 8: 30 \mathrm{AM} & 8592 & 6.2 \\ 2 / 15 / 99 & 10: 00 \mathrm{AM} & 9696 & 7.8 \\ 3 / 16 / 99 & 10: 00 \mathrm{AM} & 10392 & 8.3 \\ 4 / 30 / 99 & 9: 15 \mathrm{AM} & 11472 & 7.8 \\ 6 / 7 / 99 & 10: 00 \mathrm{AM} & 12384 & 9.8 \\ 7 / 16 / 99 & 2: 00 \mathrm{PM} & 13320 & 9.9 \\ 8 / 17 / 99 & 10: 30 \mathrm{AM} & 14088 & 8.6 \\ 10 / 14 / 99 & 11: 30 \mathrm{AM} & 15480 & 10.7\end{array}$

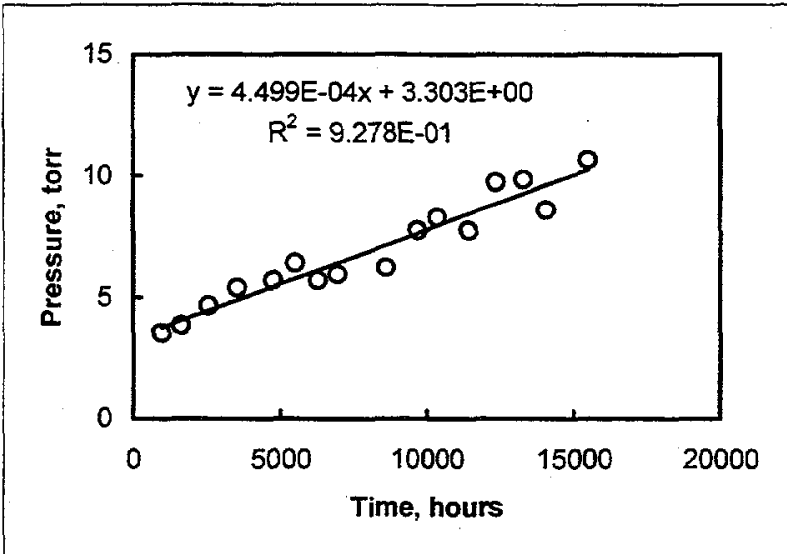

Note: data point at $t=0$ deleted from plot and regression 
Film:

E 48662-153-1

Panel:

F-IV-3

Gas:

Air

Internal Volume: $\quad 15.27 \mathrm{~cm}^{3}$

$\begin{array}{rrrr}\text { Date } & \text { Time } & \text { Hours } & \text { P, torr } \\ 1 / 7 / 98 & 9: 15 \mathrm{AM} & 0 & 4.2 \\ 2 / 17 / 98 & 10: 00 \mathrm{AM} & 984 & 3.1 \\ 3 / 17 / 98 & 2: 00 \mathrm{PM} & 1656 & 3.1 \\ 4 / 24 / 98 & 12: 00 \mathrm{AM} & 2568 & 3.1 \\ 6 / 4 / 98 & 10: 00 \mathrm{AM} & 3552 & 3.1 \\ 7 / 24 / 98 & 9: 45 \mathrm{AM} & 4752 & 3.8 \\ 8 / 24 / 98 & 2: 00 \mathrm{PM} & 5496 & 4.4 \\ 9 / 25 / 98 & 2: 00 \mathrm{PM} & 6264 & 5.1 \\ 10 / 23 / 98 & 2: 30 \mathrm{PM} & 6936 & 5.9 \\ 12 / 31 / 98 & 8: 30 \mathrm{AM} & 8592 & 6.2 \\ 2 / 15 / 99 & 10: 00 \mathrm{AM} & 9696 & 5.5 \\ 3 / 16 / 99 & 10: 00 \mathrm{AM} & 10392 & 5.0 \\ 4 / 30 / 99 & 9: 15 \mathrm{AM} & 11472 & 6.2 \\ 6 / 7 / 99 & 10: 00 \mathrm{AM} & 12384 & 5.9 \\ 7 / 16 / 99 & 2: 00 \mathrm{PM} & 13320 & 7.0 \\ 8 / 17 / 99 & 10: 30 \mathrm{AM} & 14088 & 8.3 \\ 10 / 14 / 99 & 11: 30 \mathrm{AM} & 15480 & 9.9\end{array}$

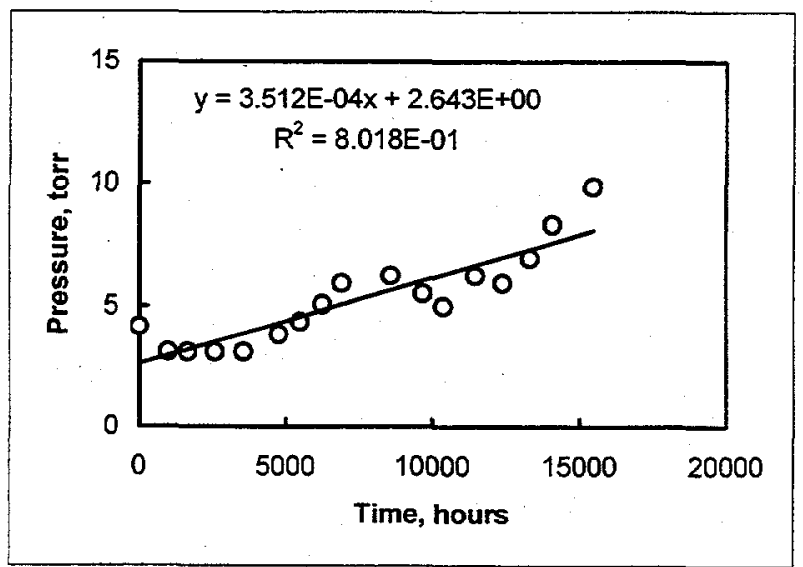


Film:

Panel Set:

Gas:

$P=a+b t$

\section{E 48662-153-1}

F-IV

Air
Panel

F-IV-1

F-IV-2

F-IV-3

$\begin{array}{rr}V, \text { cc } & \text { A, in. } \\ 0 & 196.8 \\ 7.43 & 196.0 \\ 15.27 & 198.8\end{array}$

15.27

$\begin{array}{rrrr}a & \text { b } & A^{*}(\text { Pamb-a)/b Permeance } \\ 6.073 & 1.077 E-03 & 1.423 E+08 & 0.00012 \\ 3.303 & 4.499 E-04 & 3.405 E+08 & 0.00010 \\ 2.643 & 3.512 E-04 & 4.429 E+08 & 0.00011\end{array}$

Permeance units $=c c($ STP $) / 100$ in..$^{2} \cdot a t m \cdot d a y$

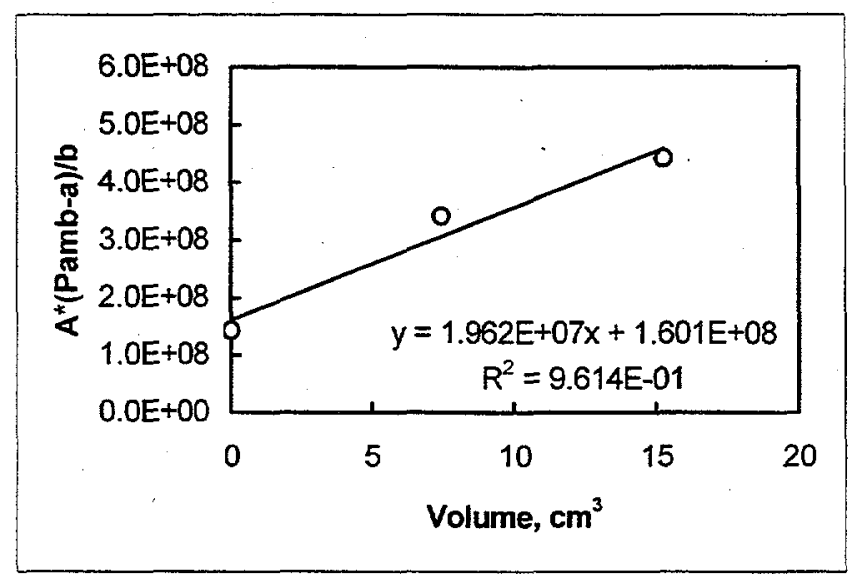
$V_{0}=$
$8.2 \mathrm{~cm}^{3}$ 
Film:

Panel:

Gas:

Internal Volume:
E 48662-153-1

F-V-1

Helium

$0 \mathrm{~cm}^{3}$

$\begin{array}{rrrr}\text { Date } & \text { Time } & \text { Hours } & \text { P, torr } \\ \text { 3/19/98 } & 11: 00 \mathrm{AM} & 0 & 4.2 \\ 3 / 20 / 98 & 9: 00 \mathrm{AM} & 21.5 & 11.1 \\ 3 / 21 / 98 & 4: 00 \mathrm{PM} & 52 & 20.7 \\ 3 / 23 / 98 & 8: 30 \mathrm{AM} & 92 & 34.5 \\ 3 / 25 / 98 & 10: 00 \mathrm{AM} & 141 & 50.0 \\ 3 / 27 / 98 & 1: 30 \mathrm{PM} & 192 & 67.4 \\ 3 / 30 / 98 & 11: 15 \mathrm{AM} & 261.25 & 90.8 \\ 4 / 2 / 98 & 2: 00 \mathrm{PM} & 335.5 & 113.6\end{array}$
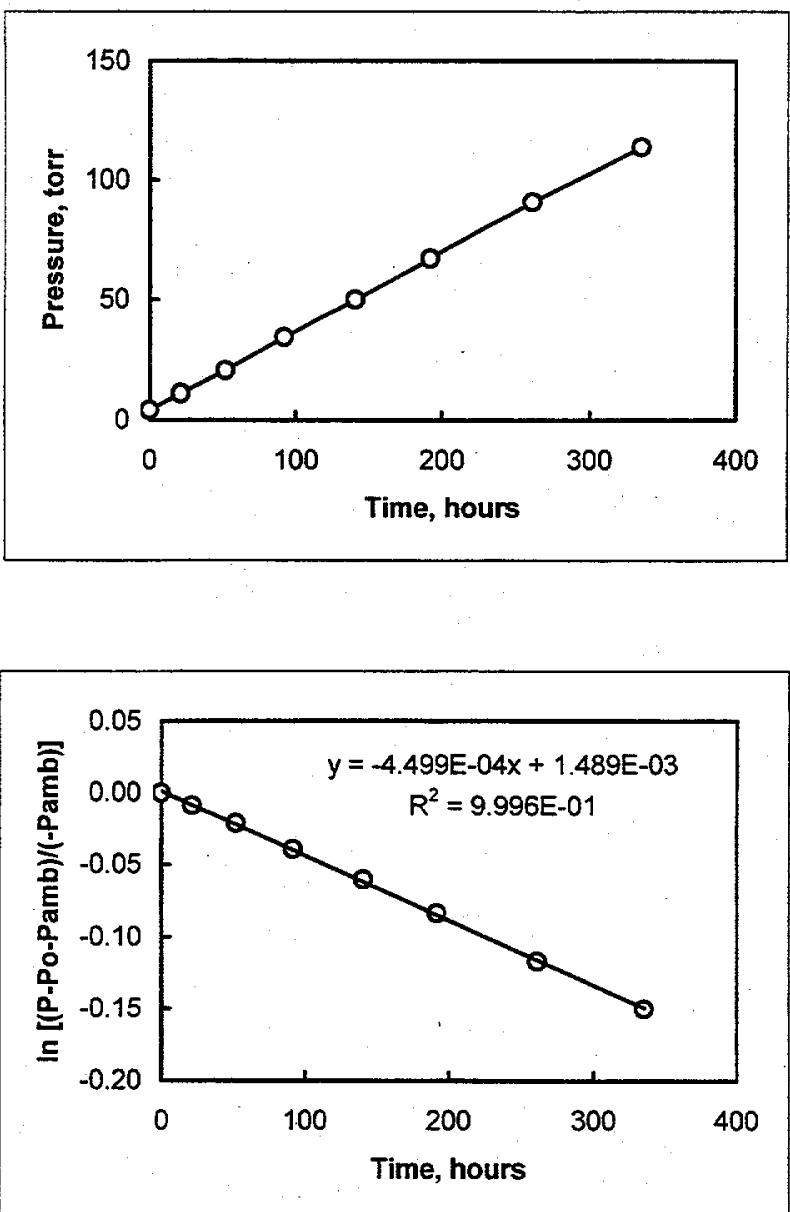
Film:

Panel:

Gas:

Internal Volume:
E 48662-153-1

F-V-2

Helium

$7.51 \mathrm{~cm}^{3}$

$\begin{array}{rrrr}\text { Date } & \text { Time } & \text { Hours } & P, \text { torr } \\ 3 / 19 / 98 & 11: 00 \mathrm{AM} & 0 & 4.2 \\ 3 / 20 / 98 & 9: 00 \mathrm{AM} & 21.5 & 7.0 \\ 3 / 21 / 98 & 4: 00 \mathrm{PM} & 52 & 9.5 \\ 3 / 25 / 98 & 10: 00 \mathrm{AM} & 141 & 21.0 \\ 3 / 27 / 98 & 1: 30 \mathrm{PM} & 192 & 29.2 \\ 3 / 30 / 98 & 11: 15 \mathrm{AM} & 261.25 & 39.1 \\ 4 / 2 / 98 & 2: 00 \mathrm{PM} & 335.5 & 48.9 \\ 4 / 7 / 98 & 1: 00 \mathrm{PM} & 454.25 & 65.6 \\ 4 / 17 / 98 & 10: 30 \mathrm{AM} & 691.25 & 96.9 \\ 4 / 24 / 98 & 9: 15 \mathrm{AM} & 857.5 & 116.0\end{array}$
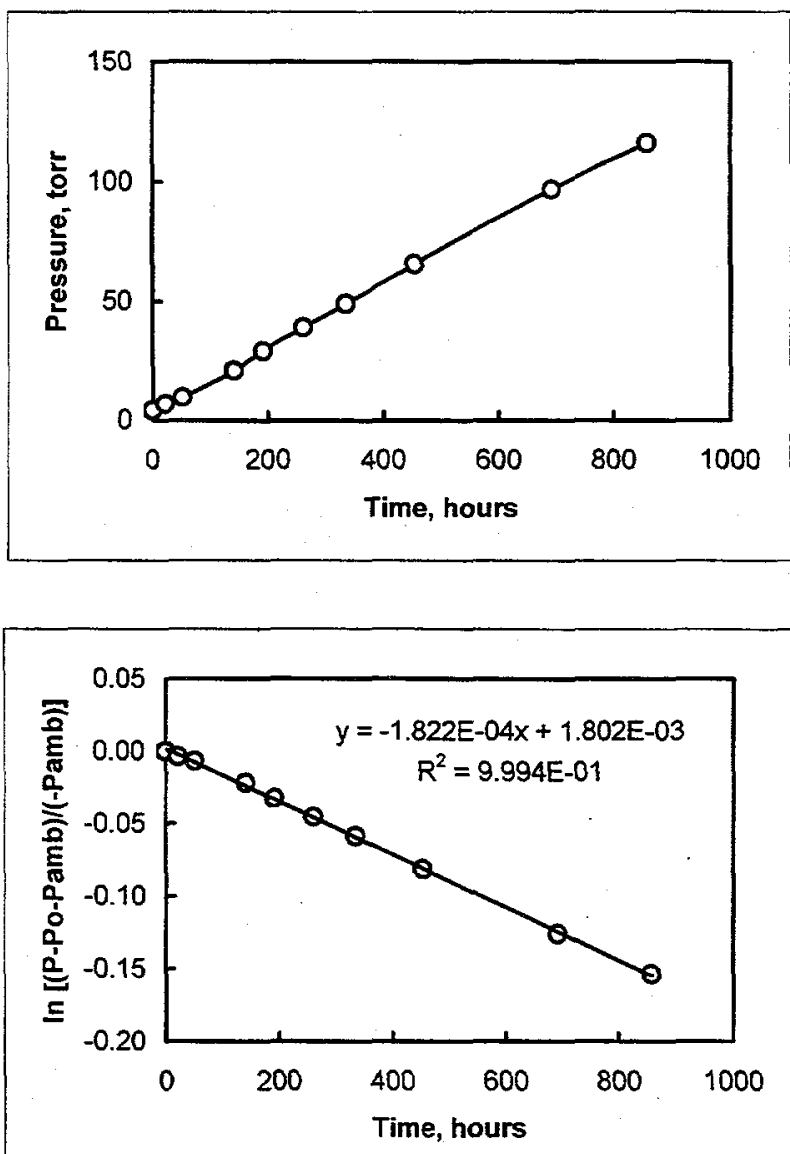
Film:

Panel:

E 48662-153-1

Gas:

F-V-3

Internal Volume:

Helium

$15.20 \mathrm{~cm}^{3}$

$\begin{array}{rrrr}\text { Date } & \text { Time } & \text { Hours } & P \text {, torr } \\ 3 / 19 / 98 & 11: 00 \mathrm{AM} & 0 & 3.1 \\ 3 / 20 / 98 & 9: 00 \mathrm{AM} & 21.5 & 3.8 \\ 3 / 21 / 98 & 4: 00 \mathrm{PM} & 52 & 6.2 \\ 3 / 23 / 98 & 8: 30 \mathrm{AM} & 92 & 10.4 \\ 3 / 25 / 98 & 10: 00 \mathrm{AM} & 141 & 14.7 \\ 3 / 27 / 98 & 1: 30 \mathrm{PM} & 192 & 19.5 \\ 3 / 30 / 98 & 11: 15 \mathrm{AM} & 261.25 & 25.9 \\ 4 / 2 / 98 & 2: 00 \mathrm{PM} & 335.5 & 32.7 \\ 4 / 7 / 98 & 1: 00 \mathrm{PM} & 454.25 & 43.4 \\ 4 / 17 / 98 & 10: 30 \mathrm{AM} & 691.25 & 64.7 \\ 4 / 24 / 98 & 9: 15 \mathrm{AM} & 857.5 & 78.0 \\ 5 / 7 / 98 & 10: 00 \mathrm{AM} & 1169.75 & 104.8\end{array}$
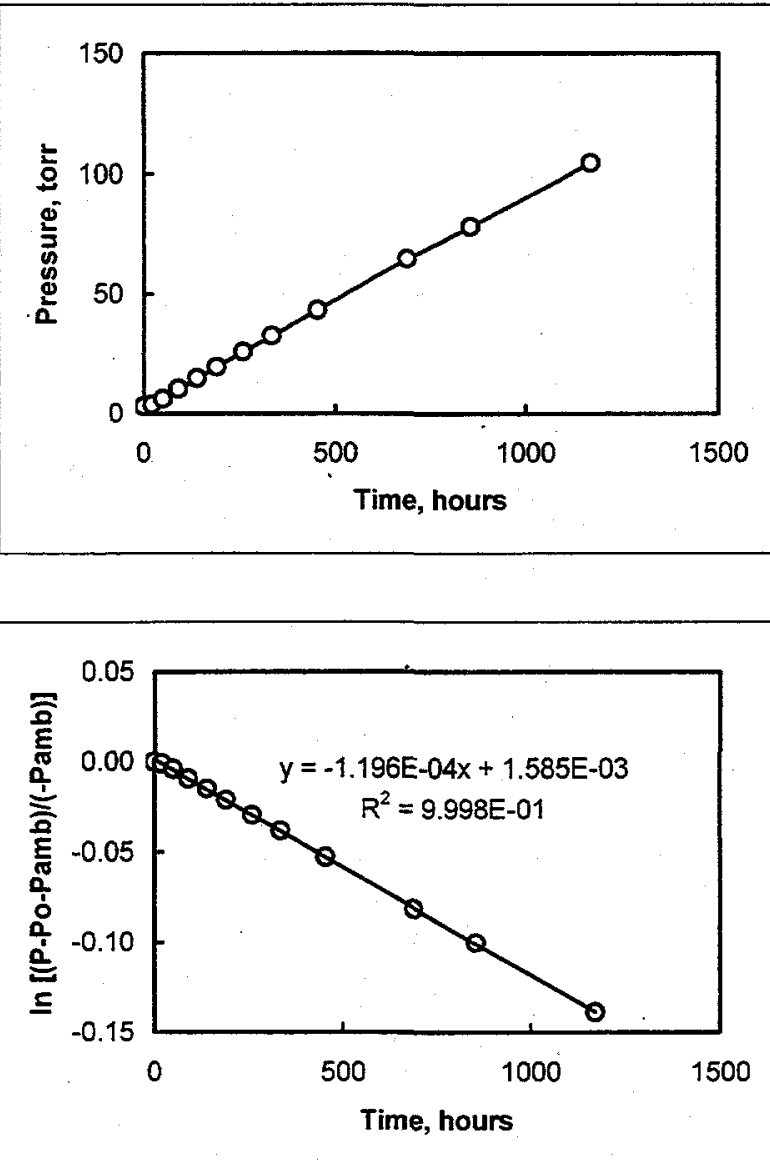
Film:

Panel Set:

E 48662-153-1

Gas:

F-V

Helium

$P=P o+P a m b[1-\exp (-b t)]$

\begin{tabular}{lrrrrr} 
Panel & $V, c c$ & $A$, in. $^{2}$ & b & \multicolumn{2}{c}{ A/b Permeance } \\
F-V-1 & 0 & 199.0 & $4.499 E-04$ & $4.423 E+05$ & 0.028 \\
F-V-2 & 7.51 & 199.0 & $1.822 E-04$ & $1.092 E+06$ & 0.026 \\
F-V-3 & 15.20 & 198.0 & $1.196 E-04$ & $1.656 E+06$ & 0.027
\end{tabular}

Permeance units $=c c(S T P) / 100$ in..$^{2} \cdot$ atm $\cdot$ day

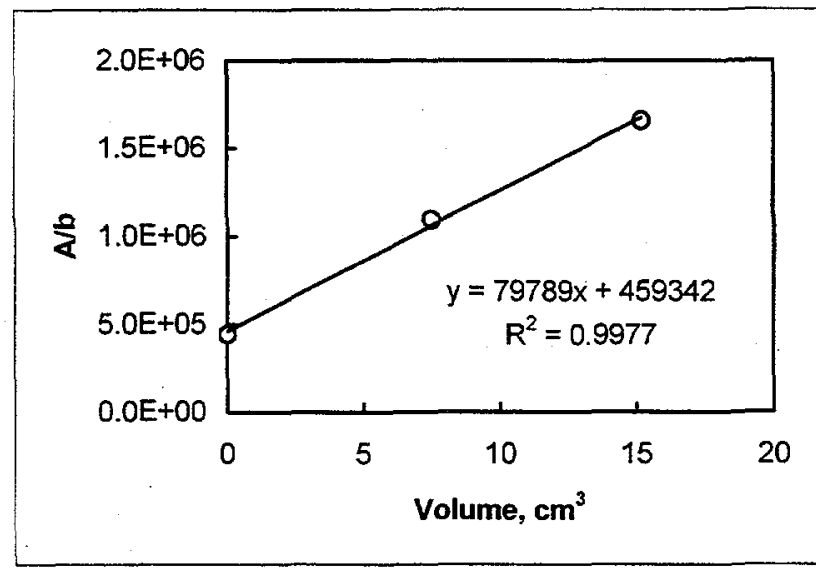

$V_{0}=\quad 5.8 \mathrm{~cm}^{3}$ 
Film:

Panel:

Gas:

Internal Volume:
VB82198-5

G-I-1

Air

$0 \mathrm{~cm}^{3}$

$\begin{array}{rrrr}\text { Date } & \text { Time } & \text { Hours } & \text { P, torr } \\ 12 / 31 / 98 & 8: 30 \mathrm{AM} & 0 & 2.8 \\ 2 / 15 / 99 & 10: 00 \mathrm{AM} & 1104 & 10.4 \\ 3 / 16 / 99 & 10: 00 \mathrm{AM} & 1800 & 13.3 \\ 4 / 30 / 99 & 9: 15 \mathrm{AM} & 2880 & 18.3 \\ 6 / 7 / 99 & 10: 00 \mathrm{AM} & 3792 & 23.6 \\ 7 / 16 / 99 & 2: 00 \mathrm{PM} & 4728 & 27.4 \\ 8 / 17 / 99 & 10: 30 \mathrm{AM} & 5496 & 30.4 \\ 10 / 14 / 99 & 11: 30 \mathrm{AM} & 6888 & 35.6\end{array}$

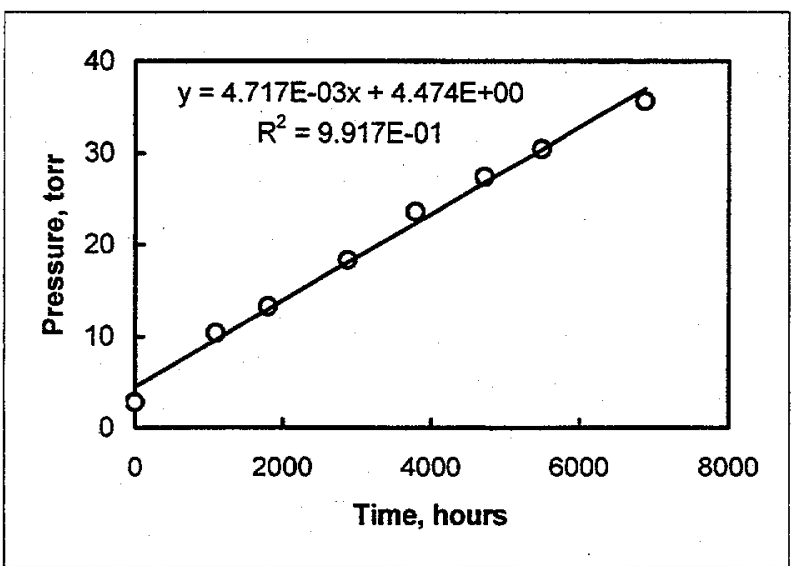


Film:

VB82198-5

Panel:

Gas:

G-1-2

Internal Volume: $\quad 7.66 \mathrm{~cm}^{3}$

$\begin{array}{rrrr}\text { Date } & \text { Time } & \text { Hours } & \text { P, torr } \\ 12 / 31 / 98 & 8: 30 \text { AM } & 0 & 4.2 \\ 2 / 15 / 99 & 10: 00 \mathrm{AM} & 1104 & 7.3 \\ 3 / 16 / 99 & 10: 00 \mathrm{AM} & 1800 & 9.2 \\ 4 / 30 / 99 & 9: 15 \mathrm{AM} & 2880 & 13.0 \\ 6 / 7 / 99 & 10: 00 \mathrm{AM} & 3792 & 17.1 \\ 7 / 16 / 99 & 2: 00 \mathrm{PM} & 4728 & 19.9 \\ 8 / 17 / 99 & 10: 30 \mathrm{AM} & 5496 & 22.8 \\ 10 / 14 / 99 & 11: 30 \mathrm{AM} & 6888 & 27.2\end{array}$

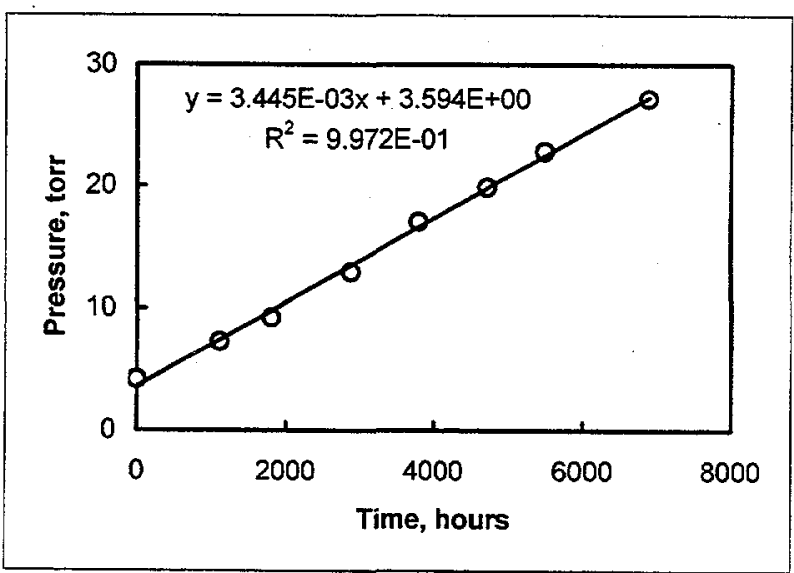


Film:

Panel:

VB82198-5

Gas:

G-I-3

Internal Volume: $\quad 15.24 \mathrm{~cm}^{3}$

$\begin{array}{rrrr}\text { Date } & \text { Time } & \text { Hours } & \text { P, torr } \\ 12 / 31 / 98 & 8: 30 \mathrm{AM} & 0 & 4.5 \\ 2 / 15 / 99 & 10: 00 \mathrm{AM} & 1104 & 4.5 \\ 3 / 16 / 99 & 10: 00 \mathrm{AM} & 1800 & 5.9 \\ 4 / 30 / 99 & 9: 15 \mathrm{AM} & 2880 & 7.8 \\ 6 / 7 / 99 & 10: 00 \mathrm{AM} & 3792 & 10.4 \\ 7 / 16 / 99 & 2: 00 \mathrm{PM} & 4728 & 12.5 \\ 8 / 17 / 99 & 10: 30 \mathrm{AM} & 5496 & 13.8 \\ 10 / 14 / 99 & 11: 30 \mathrm{AM} & 6888 & 16.6\end{array}$

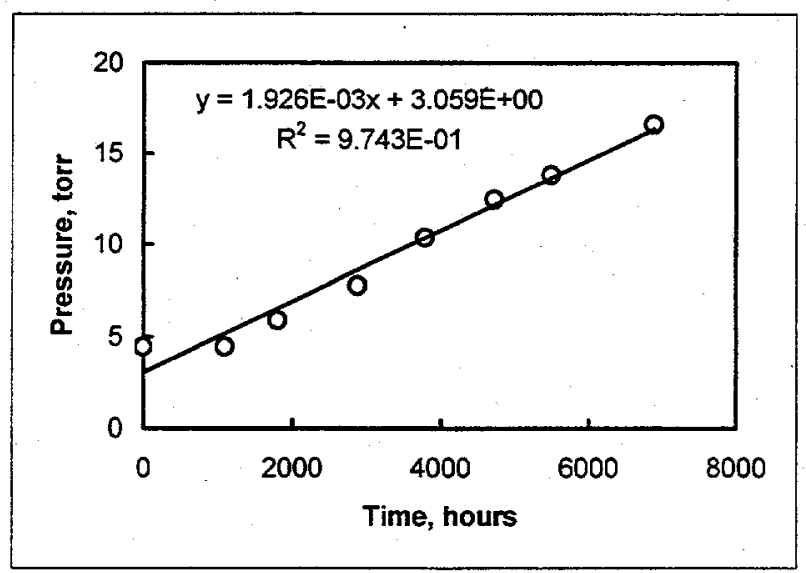


Film:

VB82198-5

Panel Set:

Gas:

G-I

Air

$P=a+b t$

\begin{tabular}{lrrrrrr} 
Panel & V, cc & A, in. ${ }^{2}$ & \multicolumn{3}{c}{ a } & \multicolumn{3}{c}{$b$} & $A^{*}($ Pamb-a)/b & Permeance \\
G-I-1 & 0 & 198.2 & 4.474 & $4.717 E-03$ & $3.280 E+07$ & 0.00060 \\
G-I-2 & 7.66 & 197.8 & 3.594 & $3.445 E-03$ & $4.487 E+07$ & 0.00081 \\
G-I-3 & 15.24 & 198.8 & 3.059 & $1.926 E-03$ & $8.071 E+07$ & 0.00065
\end{tabular}

Permeance units $=c c($ STP $) / 100$ in. ${ }^{2} \cdot a t m \cdot d a y$

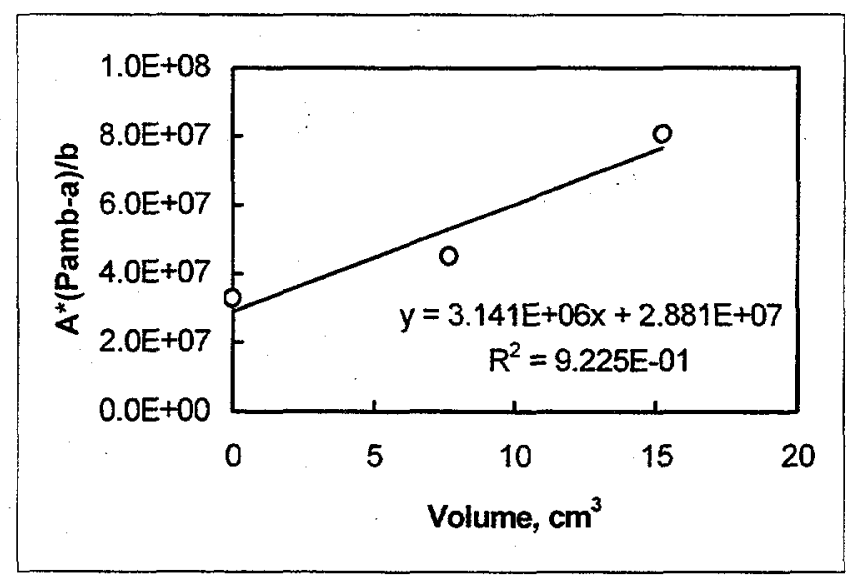

$V_{0}=\quad 9.2 \mathrm{~cm}^{3}$ 
Film:

Panel:

Gas:

Internal Volume:
Vecat

$\mathrm{V}-1-1$

Air

$0 \mathrm{~cm}^{3}$

$\begin{array}{rrrr}\text { Date } & \text { Time } & \text { Hours } & \mathrm{P}, \text { torr } \\ 7 / 15 / 95 & 6: 15 \mathrm{PM} & 0 & 8.8 \\ 7 / 29 / 95 & 2: 30 \mathrm{PM} & 332.2 & 18.1 \\ 8 / 11 / 95 & 2: 00 \mathrm{PM} & 643.7 & 18.9 \\ 8 / 25 / 95 & 7: 00 \mathrm{AM} & 972.7 & 19.0 \\ 9 / 8 / 95 & 6: 30 \mathrm{AM} & 1308.2 & 21.6 \\ 9 / 20 / 95 & 3: 00 \mathrm{PM} & 1604.7 & 22.1 \\ 10 / 5 / 95 & 3: 15 \mathrm{PM} & 1965 & 25.6 \\ 11 / 11 / 95 & 4: 35 \mathrm{PM} & 2854.3 & 29.2 \\ 1 / 17 / 96 & 7: 30 \mathrm{AM} & 4453.2 & 37.6\end{array}$

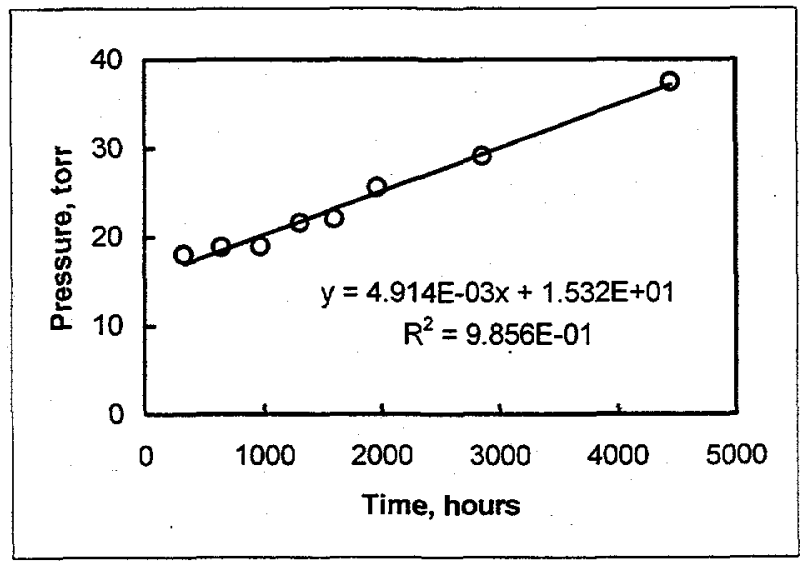

Data point at $t=0$ not plotted and not used in regression. 
$\begin{array}{ll}\text { Film: } & \text { Vecat } \\ \text { Panel: } & \text { V-l-2 } \\ \text { Gas: } & \text { Air } \\ \text { Internal Volume: } & 7.51 \mathrm{~cm}^{3}\end{array}$

$\begin{array}{rrrr}\text { Date } & \text { Time } & \text { Hours } & \text { P, torr } \\ 9 / 20 / 95 & 3: 00 \mathrm{PM} & 0 & 14.1 \\ 10 / 5 / 95 & 3: 15 \mathrm{PM} & 360.2 & 12.7 \\ 11 / 11 / 95 & 4: 35 \mathrm{PM} & 1249.6 & 10.2 \\ 1 / 17 / 96 & 7: 30 \mathrm{AM} & 2848.5 & 14.0 \\ 2 / 1 / 96 & 8: 30 \mathrm{AM} & 3209.5 & 14.5 \\ 2 / 21 / 96 & 10: 00 \mathrm{AM} & 3691 & 15.6\end{array}$

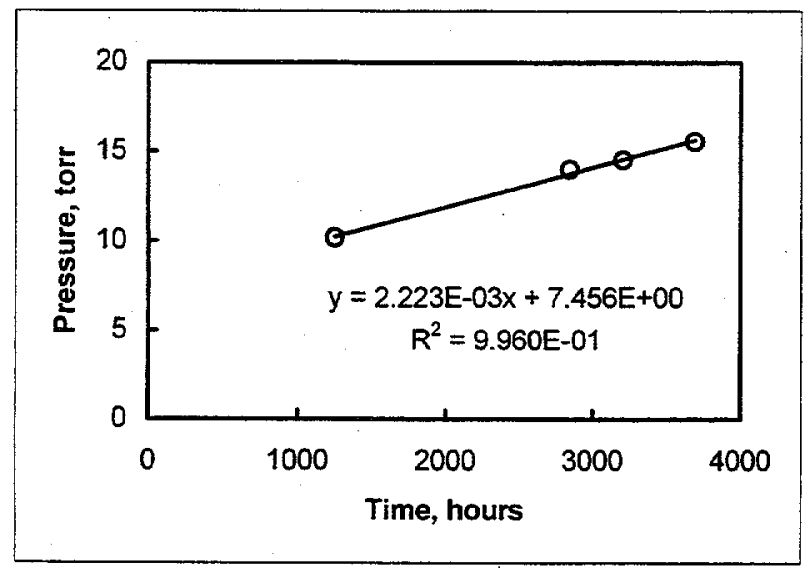

First two data points not plotted and not used in regression. 
$\begin{array}{ll}\text { Film: } & \text { Vecat } \\ \text { Panel: } & \text { V-l-3 } \\ \text { Gas: } & \text { Air }\end{array}$

Internal Volume: $\quad 15.20 \mathrm{~cm}^{3}$

$\begin{array}{rrrr}\text { Date } & \text { Time } & \text { Hours } & \mathrm{P} \text {, torr } \\ 9 / 20 / 95 & 3: 00 \mathrm{PM} & 0 & 4.3 \\ 10 / 5 / 95 & 3: 15 \mathrm{PM} & 360.2 & 10.9 \\ 11 / 11 / 95 & 4: 35 \mathrm{PM} & 1249.6 & 10.9 \\ 1 / 17 / 96 & 7: 30 \mathrm{AM} & 2848.5 & 11.1 \\ 2 / 1 / 96 & 8: 30 \mathrm{AM} & 3209.5 & 12.7 \\ 2 / 21 / 96 & 10: 00 \mathrm{AM} & 3691 & 12.7\end{array}$

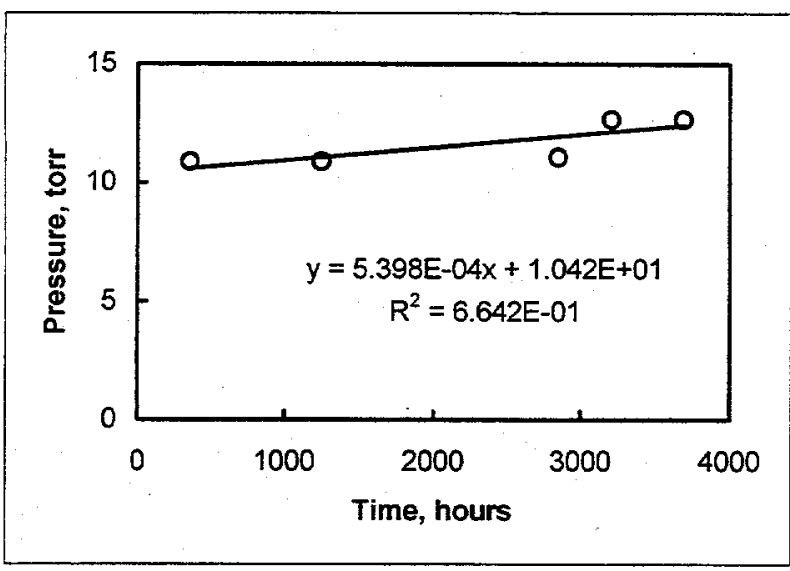

First data point not plotted and not used in regression. 
$\begin{array}{ll}\text { Film: } & \text { Vecat } \\ \text { Panel Set: } & \text { V-I } \\ \text { Gas: } & \text { Air }\end{array}$

$P=a+b t$

\begin{tabular}{lrrrrrl} 
Panel & V,cc & A, in. ${ }^{2}$ & a & \multicolumn{2}{c}{ b } & $A^{*}$ (Pamb-a)/b Permeance \\
V-I-1 & 0.00 & 312.5 & 15.32 & $4.914 E-03$ & $4.895 E+07$ & 0.00027 \\
V-I-2 & 7.51 & 312.8 & 7.456 & $2.223 E-03$ & $1.094 E+08$ & 0.00027 \\
V-I-3 & 15.20 & 317.8 & 10.42 & $5.398 E-04$ & $4.560 E+08$ & 0.00010
\end{tabular}

Permeance units $=c c(S T P) / 100$ in. $^{2} \cdot a t m \cdot d a y$

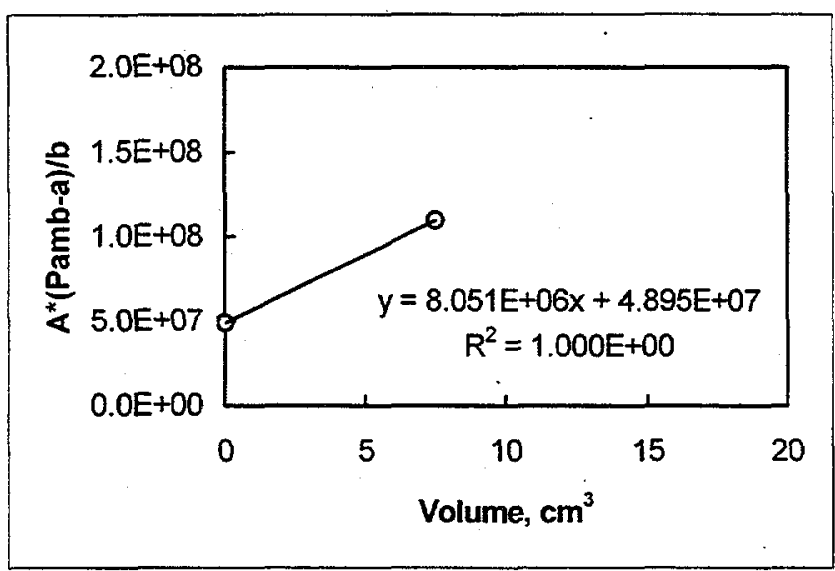

$V_{0}=\quad 6.1 \mathrm{~cm}^{3}$ 
$\begin{array}{ll}\text { Film: } & \text { Vecat } \\ \text { Panel: } & \text { V-l-1 } \\ \text { Gas: } & \text { Helium } \\ \text { Internal Volume: } & 0 \mathrm{~cm}^{3}\end{array}$

$\begin{array}{rrrr}\text { Date } & \text { Time } & \text { Hours } & \text { P, torr } \\ \text { 1/17/96 } & 11: 00 \mathrm{AM} & 0 & 37.6 \\ 1 / 17 / 96 & 5: 00 \mathrm{PM} & 6 & 168.2 \\ 1 / 18 / 96 & 1: 45 \mathrm{PM} & 26 & 455.4 \\ 1 / 19 / 96 & 3: 30 \mathrm{PM} & 51 & 629.4\end{array}$
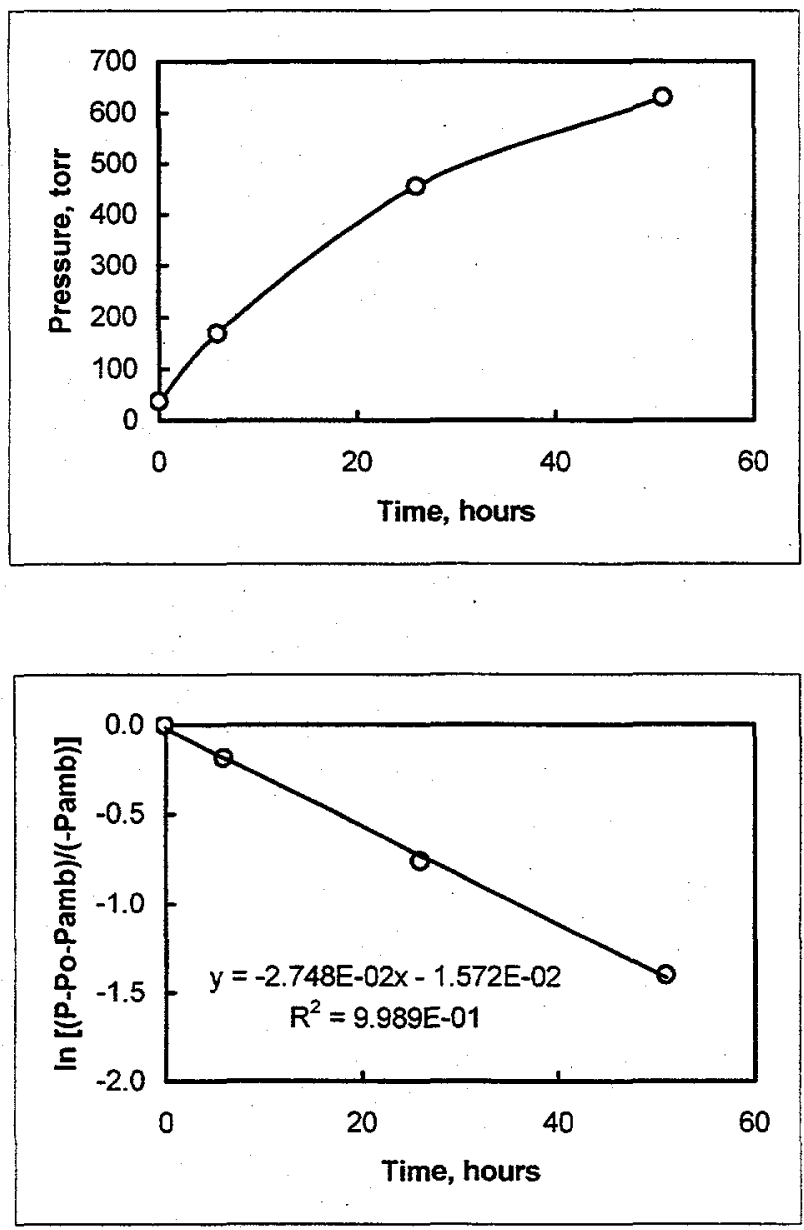
Film:

Panel:

Gas:

Vecat

$\mathrm{V}-\mathrm{I}-2$

Internal Volume: $\quad 7.51 \mathrm{~cm}^{3}$

$\begin{array}{rrrr}\text { Date } & \text { Time } & \text { Hours } & \text { P, torr } \\ 2 / 21 / 96 & 12: 00 \mathrm{PM} & 0 & 15.6 \\ 2 / 21 / 96 & 5: 00 \mathrm{PM} & 5 & 65.6 \\ 2 / 22 / 96 & 1: 00 \mathrm{PM} & 24.2 & 229.8 \\ 2 / 23 / 96 & 2: 26 \mathrm{PM} & 48.9 & 390.7 \\ 2 / 24 / 96 & 12: 30 \mathrm{PM} & 69.9 & 492.1\end{array}$
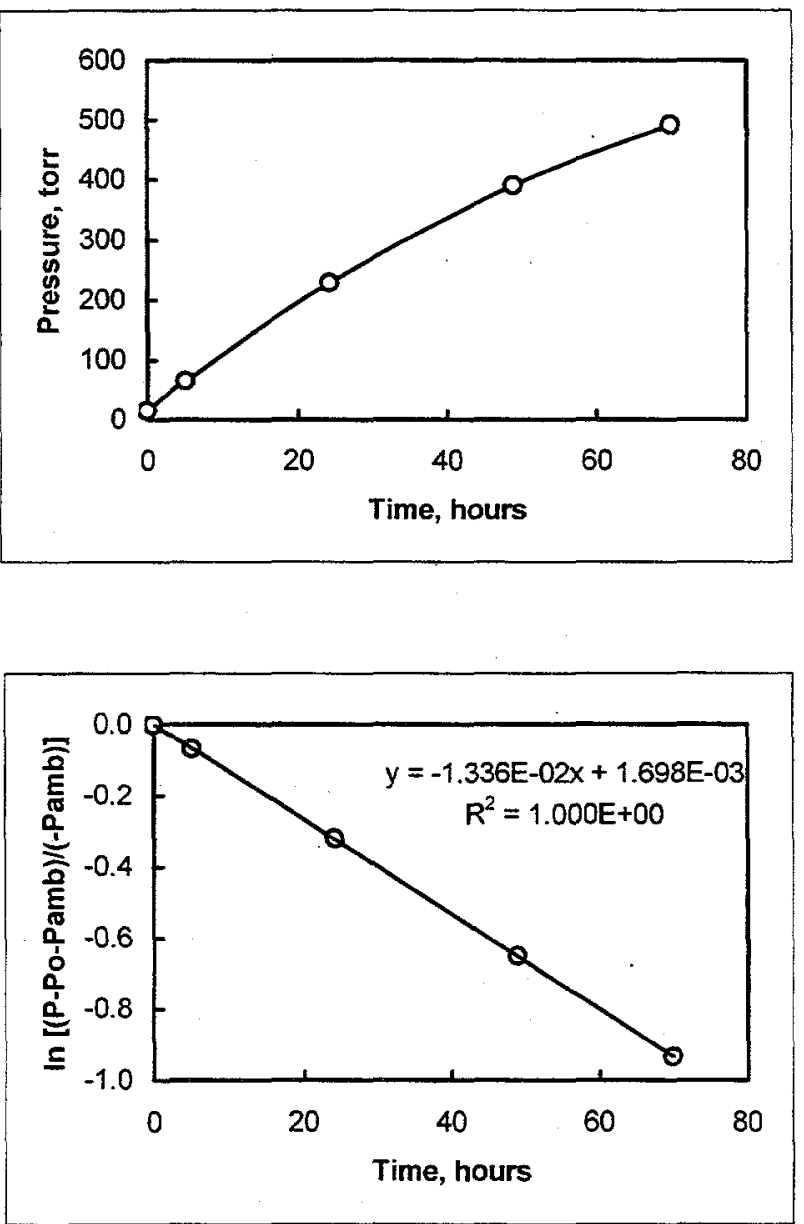
$\begin{array}{ll}\text { Film: } & \text { Vecat } \\ \text { Panel: } & \text { V-I-3 } \\ \text { Gas: } & \text { Helium } \\ \text { Internal Volume: } & 15.20 \mathrm{~cm}^{3}\end{array}$

$\begin{array}{rrrr}\text { Date } & \text { Time } & \text { Hours } & P \text {, torr } \\ 2 / 21 / 96 & 12: 00 \mathrm{PM} & 0 & 12.7 \\ 2 / 21 / 96 & 5: 00 \mathrm{PM} & 5 & 43.7 \\ 2 / 22 / 96 & 1: 00 \mathrm{PM} & 24.2 & 152.8 \\ 2 / 23 / 96 & 2: 26 \mathrm{PM} & 48.9 & 270.4 \\ 2 / 24 / 96 & 12: 30 \mathrm{PM} & 69.9 & 354.3 \\ 2 / 26 / 96 & 7: 30 \mathrm{PM} & 112.3 & 484.1\end{array}$
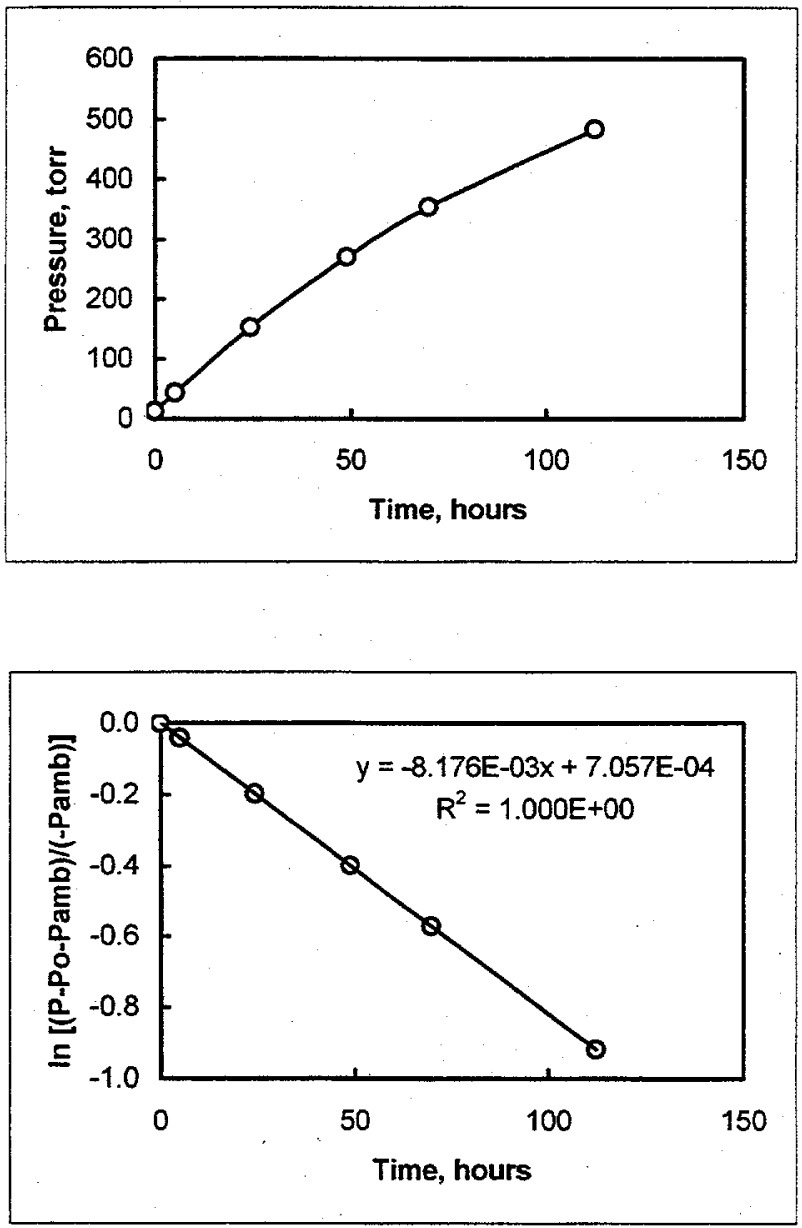
Film: Vecat

Panel Set: $\quad$ V-I

Gas: Helium

$P=P o+P a m b[1-\exp (-b t)]$

Panel $V, c c$ A, in. ${ }^{2}$ b Alb Permeance

$\begin{array}{llllll}\mathrm{V}-\mathrm{I}-1 & 0.00 & 312.5 & 2.748 \mathrm{E}-02 & 1.137 \mathrm{E}+04 & 1.13\end{array}$

$\begin{array}{llllll}\mathrm{V}-\mathrm{I}-2 & 7.51 & 312.8 & 1.336 \mathrm{E}-02 & 2.341 \mathrm{E}+04 & 1.24\end{array}$

$\begin{array}{llllll}V-1-3 & 15.20 & 317.8 & 8.176 E-03 & 3.887 E+04 & 1.17\end{array}$

Permeance units $=c c($ STP $) / 100$ in. ${ }^{2} \cdot a t m \cdot d a y$

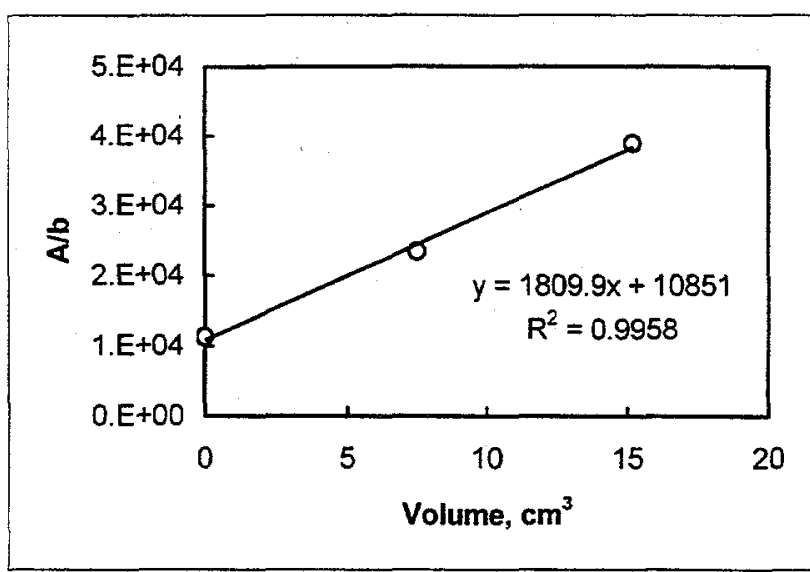

$V_{0}=\quad 6.0 \mathrm{~cm}^{3}$ 


$\begin{array}{ll}\text { Film: } & \text { Vecat } \\ \text { Panel: } & \text { V-II-1 } \\ \text { Gas: } & \text { Air } \\ \text { Internal Volume: } & 0 \mathrm{~cm}^{3}\end{array}$

$\begin{array}{rrrr}\text { Date } & \text { Time } & \text { Hours } & \mathrm{P} \text {, torr } \\ 7 / 22 / 95 & 4: 00 \mathrm{PM} & 0 & 8.8 \\ 7 / 29 / 95 & 2: 30 \mathrm{PM} & 166.5 & 15.0 \\ 8 / 11 / 95 & 2: 00 \mathrm{PM} & 478 & 17.3 \\ 8 / 25 / 95 & 7: 00 \mathrm{AM} & 807 & 18.8 \\ 9 / 8 / 95 & 6: 30 \mathrm{AM} & 1142.5 & 20.4 \\ 9 / 20 / 95 & 3: 00 \mathrm{PM} & 1439 & 23.8 \\ 10 / 5 / 95 & 3: 15 \mathrm{PM} & 1799.2 & 26.3 \\ 11 / 11 / 95 & 4: 35 \mathrm{PM} & 2688.6 & 30.4 \\ 1 / 9 / 96 & 9: 20 \mathrm{AM} & 4097.3 & 38.1\end{array}$

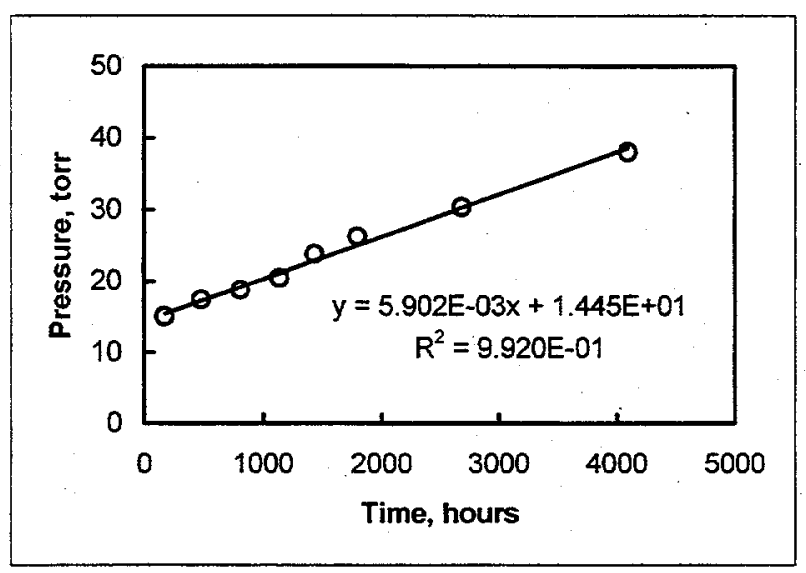

First data point not plotted and not used in regression. 
$\begin{array}{ll}\text { Film: } & \text { Vecat } \\ \text { Panel: } & \text { V-ll-2 } \\ \text { Gas: } & \text { Air } \\ \text { Internal Volume: } & 7.66 \mathrm{~cm}^{3}\end{array}$

$\begin{array}{rrrr}\text { Date } & \text { Time } & \text { Hours } & \text { P, torr } \\ 7 / 22 / 95 & 4: 00 \mathrm{PM} & 0 & 5.2 \\ 7 / 29 / 95 & 2: 30 \mathrm{PM} & 166.5 & 4.7 \\ 8 / 11 / 95 & 2: 00 \mathrm{PM} & 478 & 6.2 \\ 8 / 25 / 95 & 7: 00 \mathrm{AM} & 807 & 7.5 \\ 9 / 8 / 95 & 6: 30 \mathrm{AM} & 1142.5 & 8.1 \\ 9 / 20 / 95 & 3: 00 \mathrm{PM} & 1439 & 8.8 \\ 10 / 5 / 95 & 3: 15 \mathrm{PM} & 1799.2 & 8.6 \\ 11 / 11 / 95 & 4: 35 \mathrm{PM} & 2688.6 & 10.6 \\ 1 / 9 / 96 & 9: 20 \mathrm{AM} & 4097.3 & 14.5\end{array}$

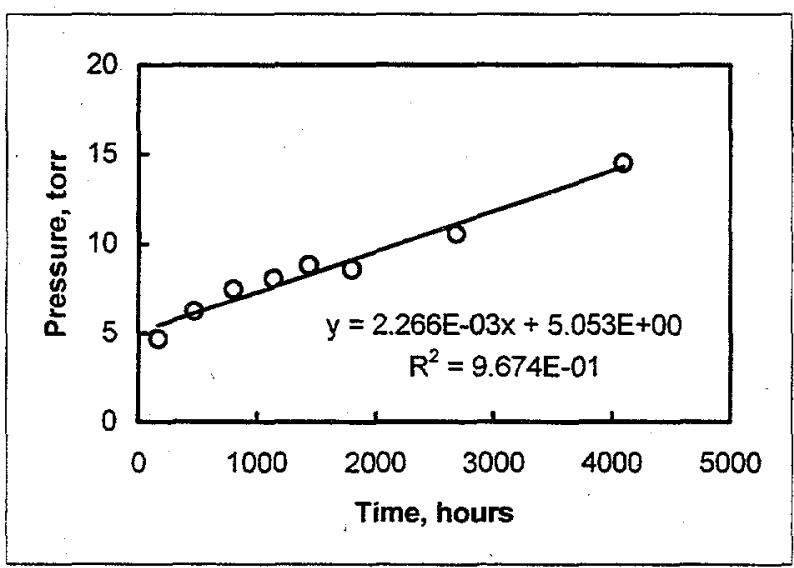

First data point not plotted and not used in regression. 
$\begin{array}{ll}\text { Film: } & \text { Vecat } \\ \text { Panel: } & \text { V-II-3 } \\ \text { Gas: } & \text { Air } \\ \text { Internal Volume: } & 15.24 \mathrm{~cm}^{3}\end{array}$

$\begin{array}{rrrr}\text { Date } & \text { Time } & \text { Hours } & \text { P, torr } \\ 7 / 22 / 95 & 4: 00 \mathrm{PM} & 0 & 8.6 \\ 7 / 29 / 95 & 2: 30 \mathrm{PM} & 166.5 & 8.8 \\ 8 / 11 / 95 & 2: 00 \mathrm{PM} & 478 & 9.3 \\ 8 / 25 / 95 & 7: 00 \mathrm{AM} & 807 & 9.0 \\ 9 / 8 / 95 & 6: 30 \mathrm{AM} & 1142.5 & 9.7 \\ 9 / 20 / 95 & 3: 00 \mathrm{PM} & 1439 & 10.9 \\ 10 / 5 / 95 & 3: 15 \mathrm{PM} & 1799.2 & 11.2 \\ 11 / 11 / 95 & 4: 35 \mathrm{PM} & 2688.6 & 11.8 \\ 1 / 9 / 96 & 9: 20 \mathrm{AM} & 4097.3 & 13.0\end{array}$

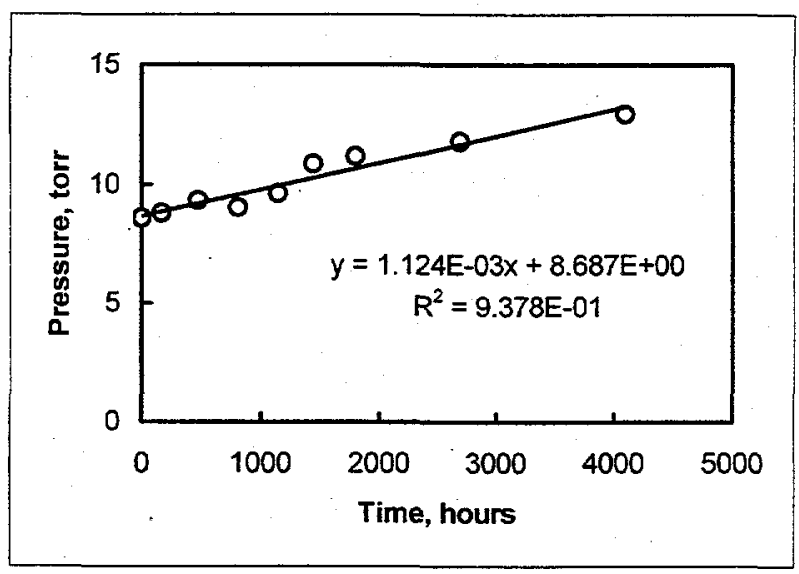


$\begin{array}{ll}\text { Film: } & \text { Vecat } \\ \text { Panel Set: } & \text { V-Il } \\ \text { Gas: } & \text { Air }\end{array}$

$P=a+b t$

Panel $\quad V, c c \quad A$, in. $^{2}$ a $\quad b A^{*}($ Pamb-a)/b Permeance

$\begin{array}{lllllll}V-11-1 & 0.00 & 316.4 & 14.45 & 5.902 \mathrm{E}-03 & 4.131 \mathrm{E}+07 & 0.00024\end{array}$

$\begin{array}{lllllll}V-11-2 & 7.66 & 316.0 & 5.053 & 2.266 \mathrm{E}-03 & 1.088 \mathrm{E}+08 & 0.00024\end{array}$

$\begin{array}{llllll}V-I I-3 & 15.24 & 317.0 & 8.687 \cdot 1.124 E-03 & 2.189 E+08 & 0.00020\end{array}$

Permeance units $=c c(S T P) / 100$ in. $^{2} \cdot a t m \cdot d a y$

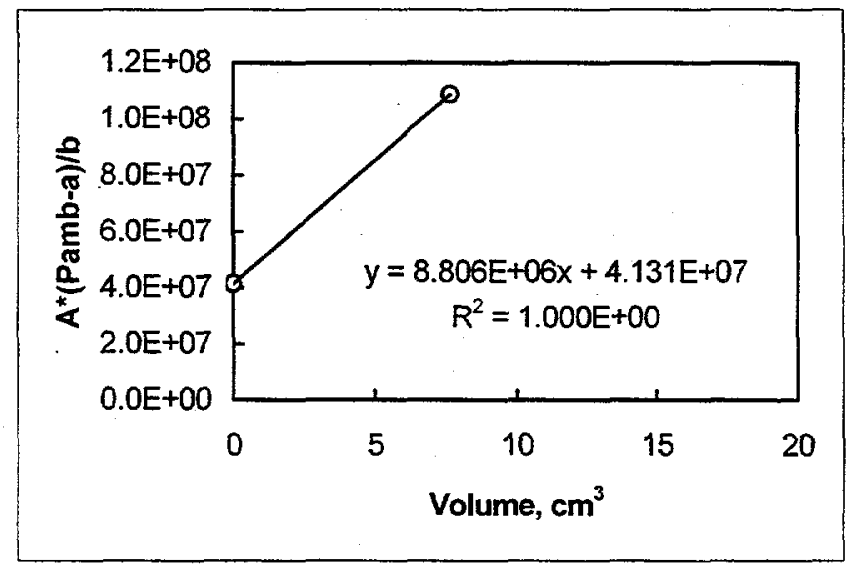

$V_{0}=\quad 4.7 \mathrm{~cm}^{3}$ 
Film:

Vecat

Panel:

Gas:

V-II-1

Internal Volume: $\quad 0 \mathrm{~cm}^{3}$
Internal Volume:

$\begin{array}{rrrr}\text { Date } & \text { Time } & \text { Hours } & P \text {, torr } \\ 1 / 9 / 96 & 10: 15 \mathrm{AM} & 0 & 38.1 \\ 1 / 9 / 96 & 4: 15 \mathrm{PM} & 6 & 151.0 \\ 1 / 10 / 96 & 11: 00 \mathrm{AM} & 24 & 410.7 \\ 1 / 11 / 96 & 2: 15 \mathrm{PM} & 50 & 599.0\end{array}$
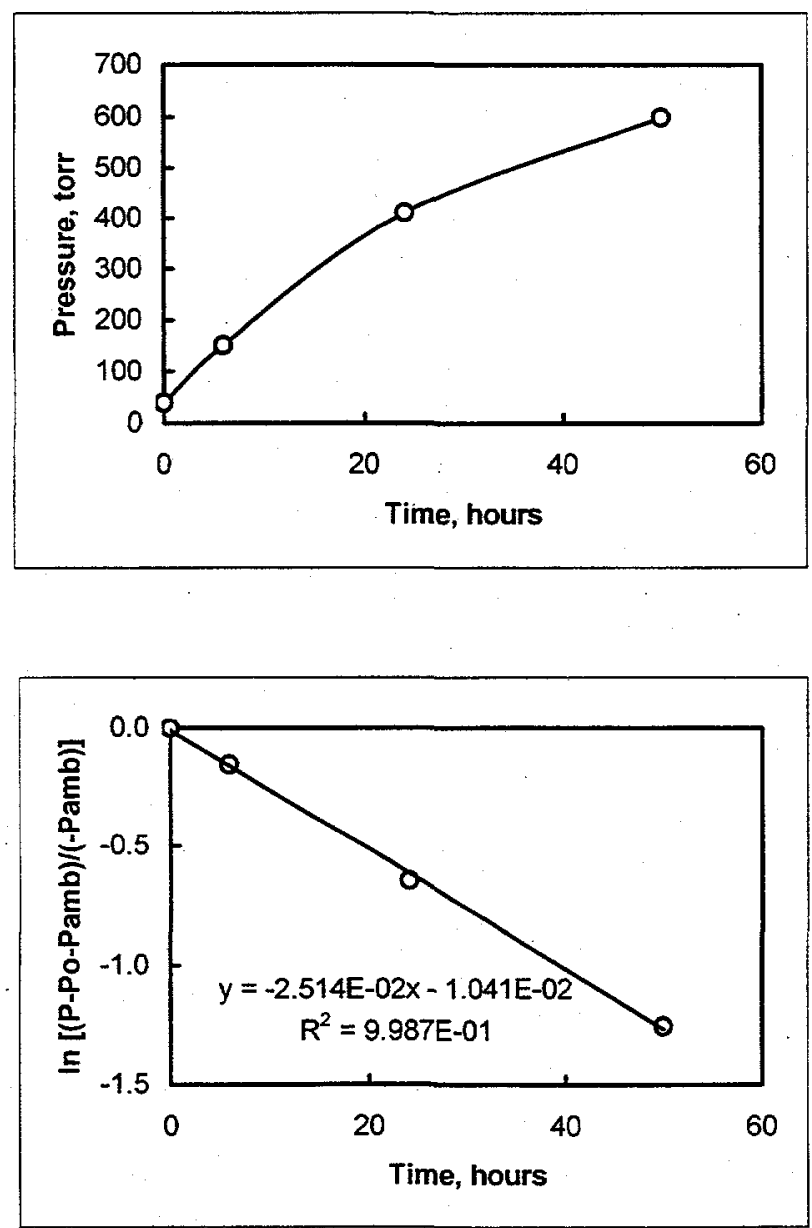
Film:

Panel:

Gas:

Internal Volume:
Vecat

V-11-2

Helium

$7.66 \mathrm{~cm}^{3}$

$\begin{array}{rrrr}\text { Date } & \text { Time } & \text { Hours } & P \text {, torr } \\ 1 / 9 / 96 & 10: 15 \mathrm{AM} & 0 & 14.5 \\ 1 / 9 / 96 & 4: 15 \mathrm{PM} & 6 & 67.4 \\ 1 / 10 / 96 & 11: 00 \mathrm{AM} & 24 & 207.3 \\ 1 / 11 / 96 & 2: 15 \mathrm{PM} & 50 & 370.6 \\ 1 / 13 / 96 & 3: 15 \mathrm{PM} & 98 & 572.3\end{array}$
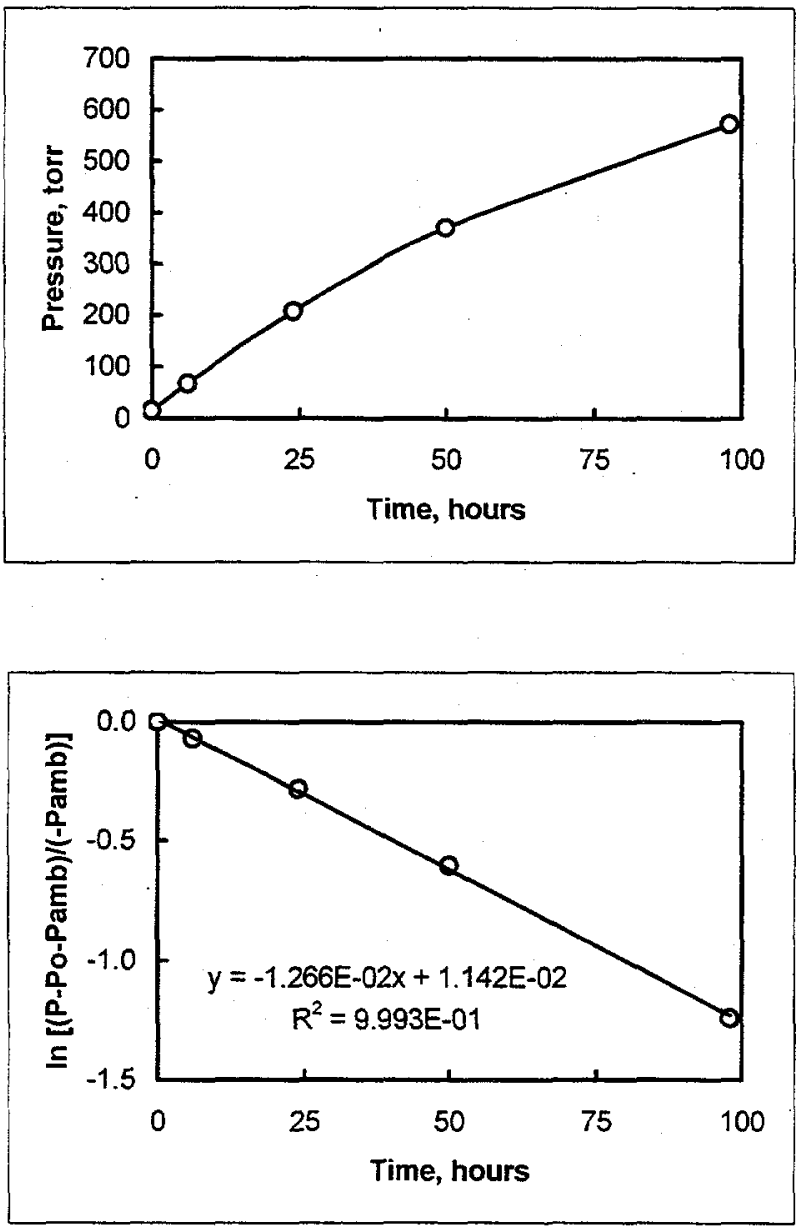
$\begin{array}{ll}\text { Film: } & \text { Vecat } \\ \text { Panel: } & \text { V-ll-3 } \\ \text { Gas: } & \text { Helium } \\ \text { Internal Volume: } & 15.24 \mathrm{~cm}^{3}\end{array}$

$\begin{array}{rrrr}\text { Date } & \text { Time } & \text { Hours } & \text { P, torr } \\ \text { 1/9/96 } & 10: 15 \mathrm{AM} & 0 & 13.0 \\ 1 / 9 / 96 & 4: 15 \mathrm{PM} & 6 & 46.0 \\ 1 / 10 / 96 & 11: 00 \mathrm{AM} & 24 & 144.5 \\ 1 / 11 / 96 & 2: 15 \mathrm{PM} & 50 & 267.3 \\ 1 / 13 / 96 & 3: 15 \mathrm{PM} & 98 & 432.2 \\ 1 / 16 / 96 & 8: 00 \mathrm{AM} & 162.2 & 582.7\end{array}$
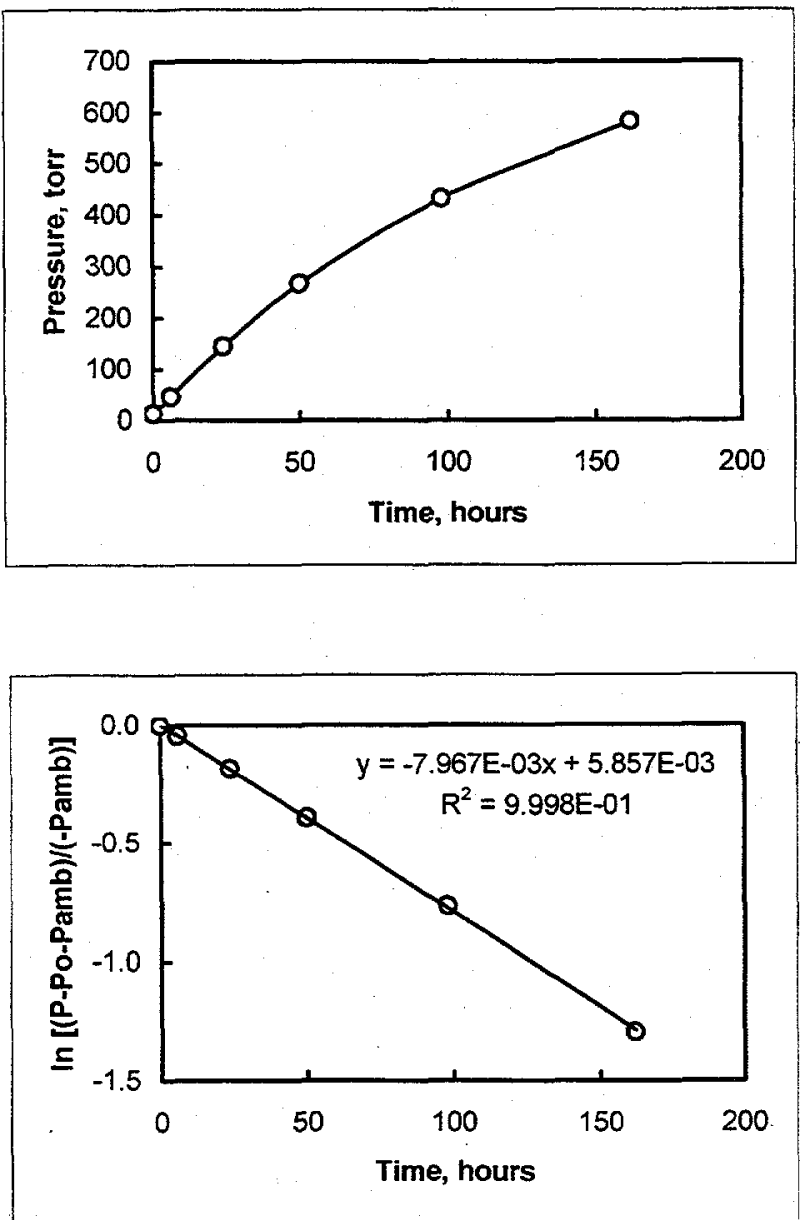
$\begin{array}{ll}\text { Film: } & \text { Vecat } \\ \text { Panel Set: } & \text { V-11 } \\ \text { Gas: } & \text { Helium }\end{array}$

$P=P o+P a m b[1-\exp (-b t)]$

Panel $\quad V, c c \quad A$, in. ${ }^{2}$ b $\quad$ A $b$. Permeance

$\begin{array}{llllll}\text { V-II-1 } & 0.00 & 316.4 & 2.514 \mathrm{E}-02 & 1.259 \mathrm{E}+04 & 1.16\end{array}$

$\begin{array}{llllll}V-I I-2 & 7.66 & 316.0 & 1.266 E-02 & 2.496 E+04 & 1.24\end{array}$

$\begin{array}{llllll}\text { V-II-3 } & 15.24 & 317.0 & 7.967 E-03 & 3.979 E+04 & 1.19\end{array}$

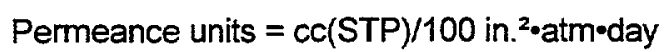

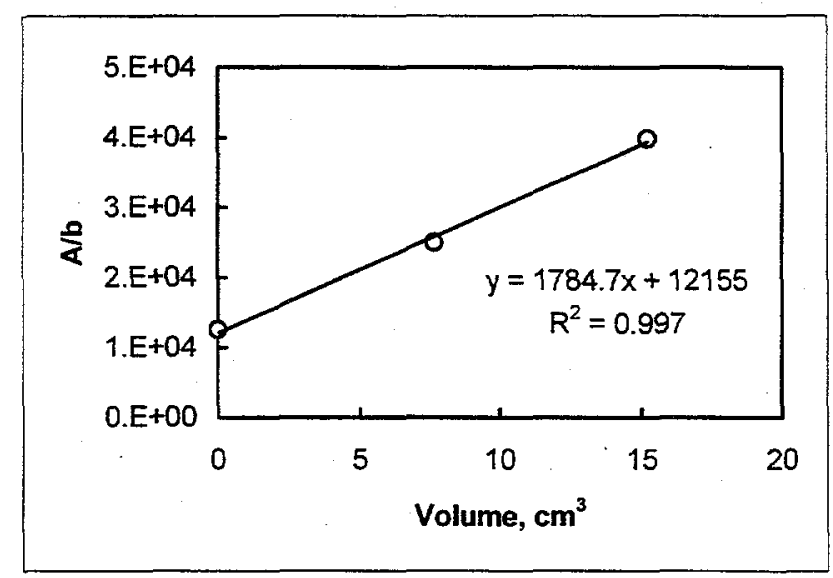

$V_{0}=\quad 6.8 \mathrm{~cm}^{3}$ 


$\begin{array}{ll}\text { Film: } & \text { Vecat } \\ \text { Panel: } & \text { V-lll-1 } \\ \text { Gas: } & \text { Air } \\ \text { Internal Volume: } & 0 \mathrm{~cm}^{3}\end{array}$

$\begin{array}{rrrr}\text { Date } & \text { Time } & \text { Hours } & \text { P, torr } \\ 9 / 20 / 95 & 3: 00 \mathrm{PM} & 0 & 16.2 \\ 10 / 5 / 95 & 3: 15 \mathrm{PM} & 360.2 & 13.7 \\ 11 / 11 / 95 & 4: 35 \mathrm{PM} & 1249.68 & 18.5 \\ 1 / 17 / 96 & 7: 30 \mathrm{AM} & 2848.5 & 27.0 \\ 2 / 1 / 96 & 8: 30 \mathrm{AM} & 3209.5 & 28.4 \\ 2 / 21 / 96 & 10: 00 \mathrm{AM} & 3691 & 32.0\end{array}$

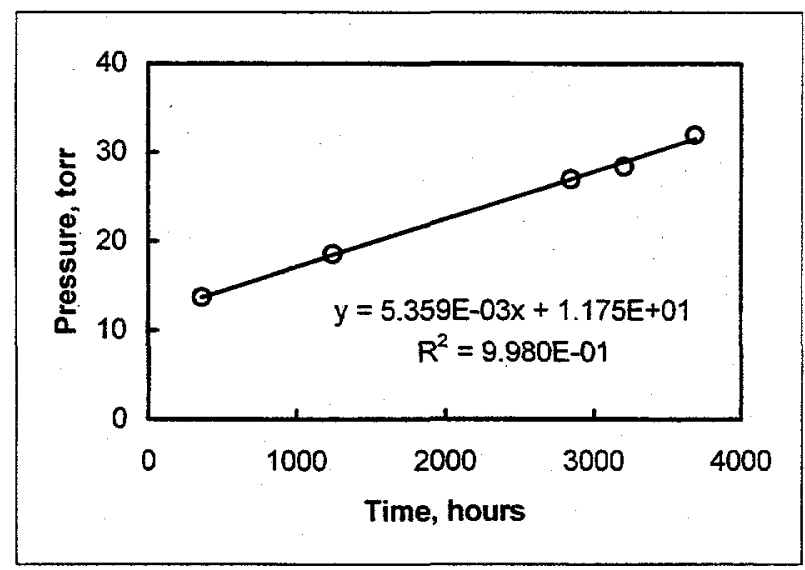

First data point not plotted and not used in regression. 
$\begin{array}{ll}\text { Film: } & \text { Vecat } \\ \text { Panel: } & \text { V-III-2 } \\ \text { Gas: } & \text { Air } \\ \text { Internal Volume: } & 7.47 \mathrm{~cm}^{3}\end{array}$

$\begin{array}{rrrr}\text { Date } & \text { Time } & \text { Hours } & \text { P, torr } \\ 7 / 29 / 95 & 2: 30 \mathrm{PM} & 0 & 4.2 \\ 8 / 11 / 95 & 2: 00 \mathrm{PM} & 311.5 & 7.8 \\ 8 / 25 / 95 & 7: 00 \mathrm{AM} & 640.5 & 6.7 \\ 9 / 8 / 95 & 6: 30 \mathrm{AM} & 976 & 9.7 \\ 9 / 20 / 95 & 3: 00 \mathrm{PM} & 1272.5 & 10.9 \\ 10 / 5 / 95 & 3: 15 \mathrm{PM} & 1632.8 & 11.4 \\ 11 / 11 / 95 & 4: 35 \mathrm{PM} & 2522.1 & 12.7 \\ 1 / 17 / 96 & 7: 30 \mathrm{AM} & 4121 & 17.2 \\ 2 / 1 / 96 & 8: 30 \mathrm{AM} & 4482 & 17.2 \\ 2 / 21 / 96 & 10: 00 \mathrm{AM} & 4963.5 & 19.0\end{array}$

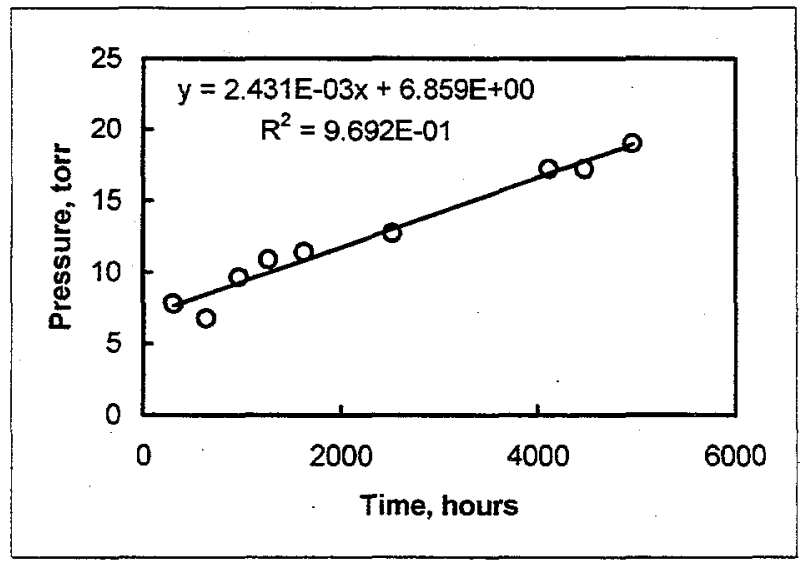

First data point not plotted and not used in regression. 


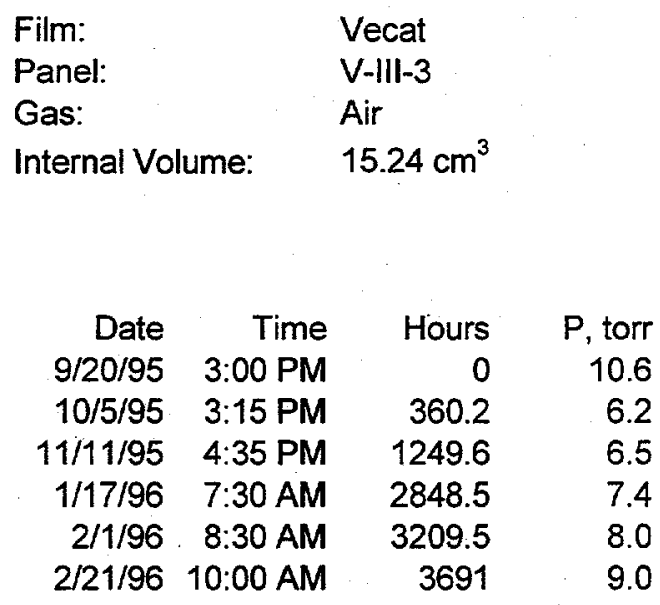

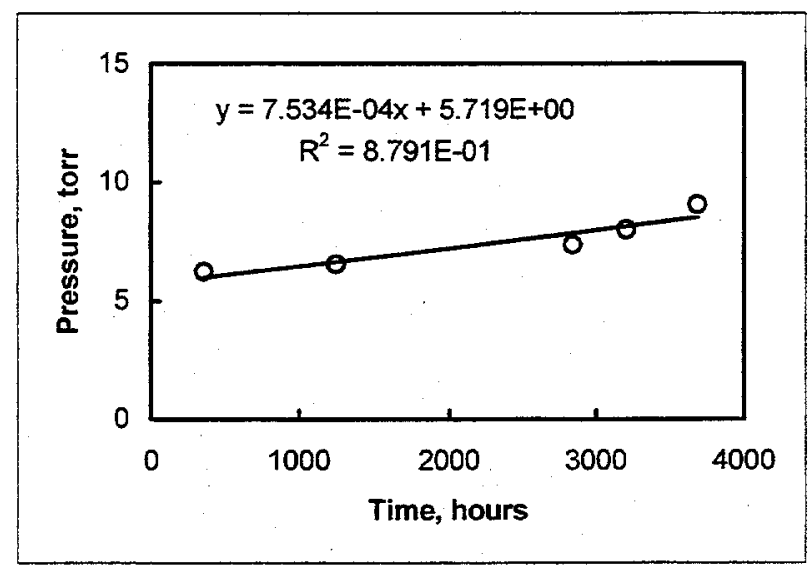

First data point not plotted and not used in regression. 
$\begin{array}{ll}\text { Film: } & \text { Vecat } \\ \text { Panel Set: } & \text { V-III } \\ \text { Gas: } & \text { Air }\end{array}$

$P=a+b t$

Panel $V, c c \quad A$, in. ${ }^{2}$ a $\quad b A^{*}($ Pamb-a)/b Permeance

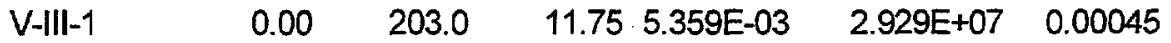

$\begin{array}{lllllll}V-111-2 & 7.47 & 201.0 & 6.859 & 2.431 E-03 & 6.434 E+07 & 0.00046\end{array}$

$\begin{array}{lllllll}\text { V-III-3 } & 15.24 & 202.8 & 5.719 & 7.534 E-04 & 2.098 E+08 & 0.00022\end{array}$

Permeance units $=c c($ STP $) / 100$ in $^{2}{ }^{2}$ atm $\cdot$ day

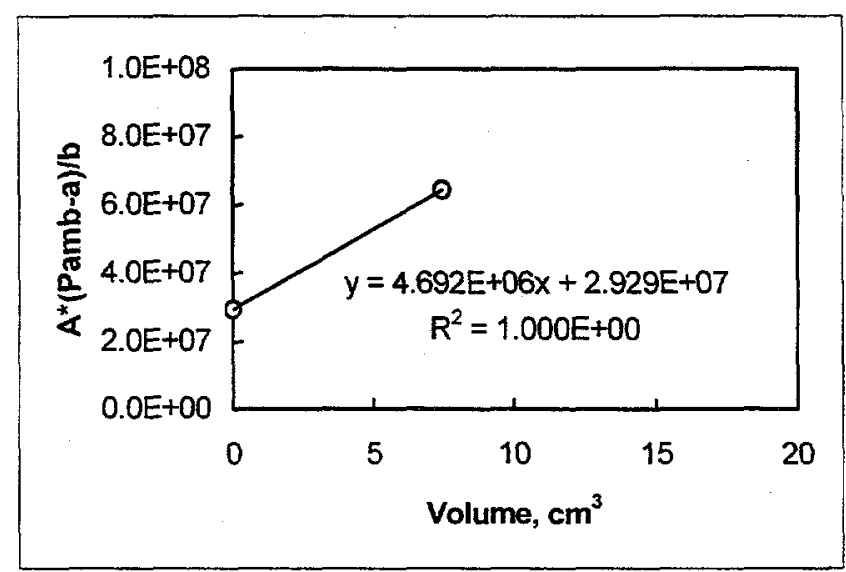
$V_{0}=$
$6.2 \mathrm{~cm}^{3}$ 
Film:

Vecat

Panel:

V-III-1

Gas:

Helium

Internal Volume: $\quad 0 \mathrm{~cm}^{3}$

$\begin{array}{rrrr}\text { Date } & \text { Time } & \text { Hours } & \text { P, torr } \\ 2 / 21 / 96 & 12: 00 \mathrm{PM} & 0 & 32.0 \\ 2 / 21 / 96 & 5: 00 \mathrm{PM} & 5 & 139.2 \\ 2 / 22 / 96 & 1: 00 \mathrm{PM} & 24.2 & 447.8 \\ 2 / 23 / 96 & 2: 26 \mathrm{PM} & 48.9 & 607.6\end{array}$
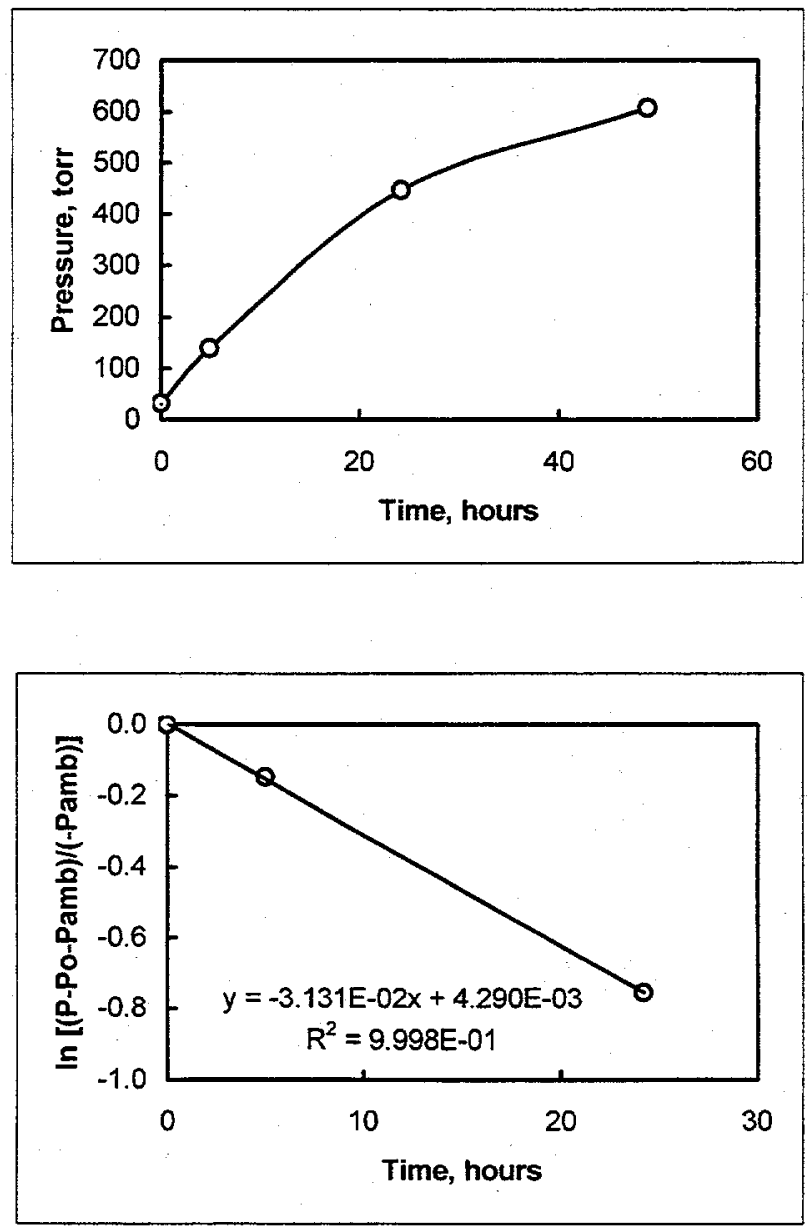

Last data point not used in regression. 
Film:

Vecat

Panel:

V-III-2

Gas:

Helium

Internal Volume: $\quad 7.47 \mathrm{~cm}^{3}$

$\begin{array}{rrrr}\text { Date } & \text { Time } & \text { Hours } & \text { P, torr } \\ \text { 2/21/96 } & 12: 00 \mathrm{PM} & 0 & 19.0 \\ 2 / 21 / 96 & 5: 00 \mathrm{PM} & 5 & 66.8 \\ \text { 2/22/96 } & 1: 00 \mathrm{PM} & 24.2 & 229.8 \\ \text { 2/23/96 } & 2: 26 \mathrm{PM} & 48.9 & 379.3 \\ 2 / 24 / 96 & 12: 30 \mathrm{PM} & 69.9 & 477.9\end{array}$
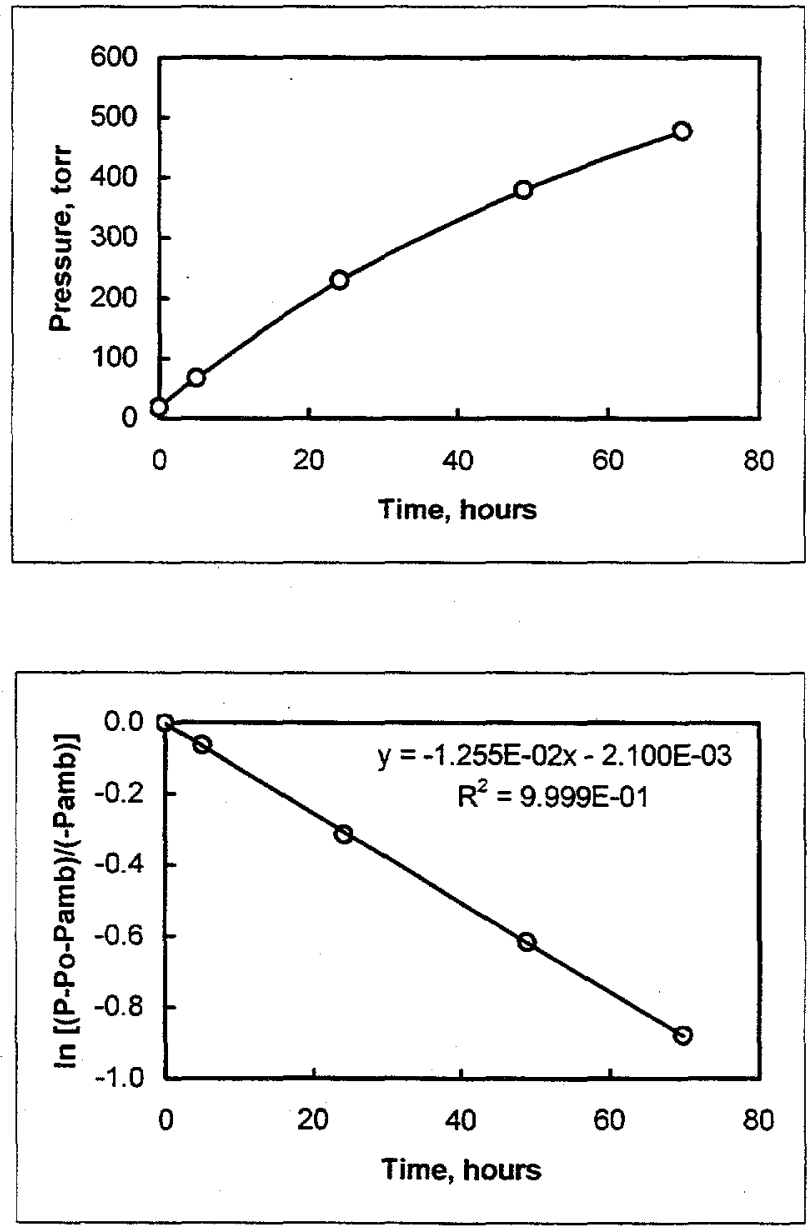
$\begin{array}{ll}\text { Film: } & \text { Vecat } \\ \text { Panel: } & \text { V-IIl-3 } \\ \text { Gas: } & \text { Helium } \\ \text { Internal Volume: } & 15.24 \mathrm{~cm}^{3}\end{array}$

$\begin{array}{rrrr}\text { Date } & \text { Time } & \text { Hours } & P, \text { torr } \\ 2 / 21 / 96 & 12: 00 \mathrm{PM} & 0 & 9.0 \\ 2 / 21 / 96 & 5: 00 \mathrm{PM} & 5 & 39.8 \\ 2 / 22 / 96 & 1: 00 \mathrm{PM} & 24.2 & 149.6 \\ 2 / 23 / 96 & 2: 26 \mathrm{PM} & 48.9 & 267.0 \\ 2 / 24 / 96 & 12: 30 \mathrm{PM} & 69.9 & 343.9 \\ 2 / 26 / 96 & 7: 30 \mathrm{AM} & 112.3 & 469.9\end{array}$
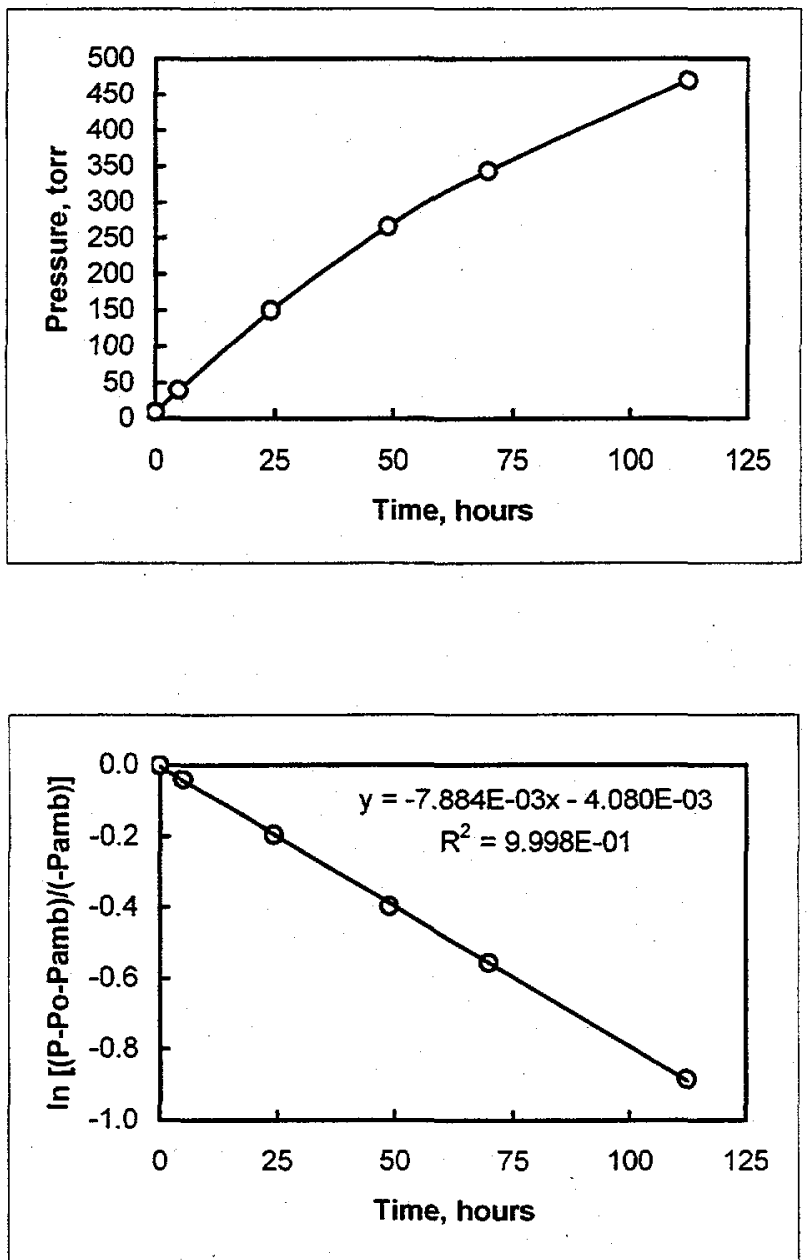
Film: Vecat

Panel Set: V-III

Gas: Helium

$P=P o+P a m b[1-\exp (-b t)]$

\begin{tabular}{lrrrrr} 
Panel & V, cc & A, in. ${ }^{2}$ & b & \multicolumn{2}{c}{ A/b Permeance } \\
V-III-1 & 0.00 & 203.0 & $3.131 \mathrm{E}-02$ & $6.484 \mathrm{E}+03$ & 1.72 \\
V-III-2 & 7.47 & 201.0 & $1.255 \mathrm{E}-02$ & $1.602 \mathrm{E}+04$ & 1.70 \\
V-III-3 & 15.24 & 202.8 & $7.884 \mathrm{E}-03$ & $2.572 \mathrm{E}+04$ & 1.71
\end{tabular}

Permeance units $=c c(S T P) / 100$ in. $^{2} \cdot$ atm $\cdot$ day

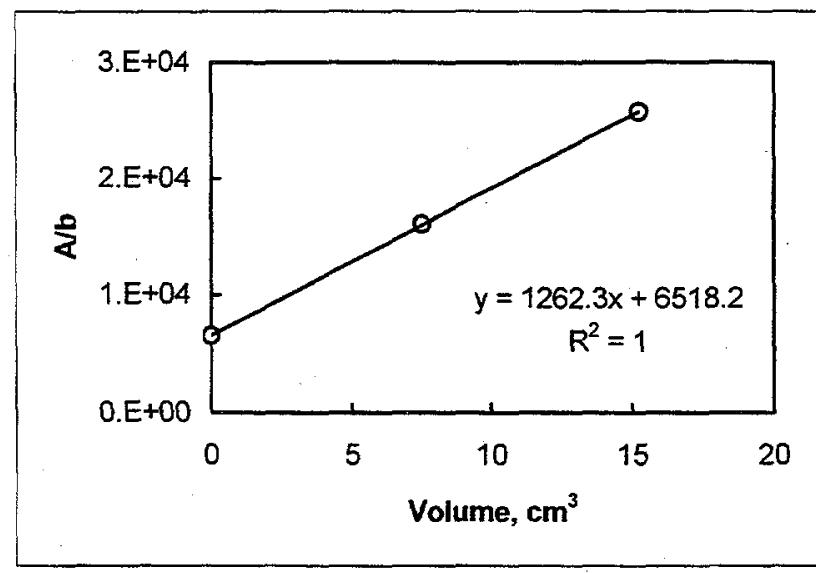

$V_{0}=\quad 5.2 \mathrm{~cm}^{3}$ 
Film:

Panel:

Gas:

Vecat

4 inch wide heat seal

Helium

Internal Volume: $\quad 0 \mathrm{~cm}^{3}$

$\begin{array}{rrrr}\text { Date } & \text { Time } & \text { Hours } & P, \text { torr } \\ 3 / 28 / 99 & 9: 30 \mathrm{AM} & 0 & 7.9 \\ 3 / 28 / 99 & 5: 50 \mathrm{PM} & 8 & 135.3 \\ 3 / 29 / 99 & 10: 05 \mathrm{AM} & 24 & 327.9 \\ 3 / 30 / 99 & 10: 20 \mathrm{AM} & 48 & 503.8\end{array}$
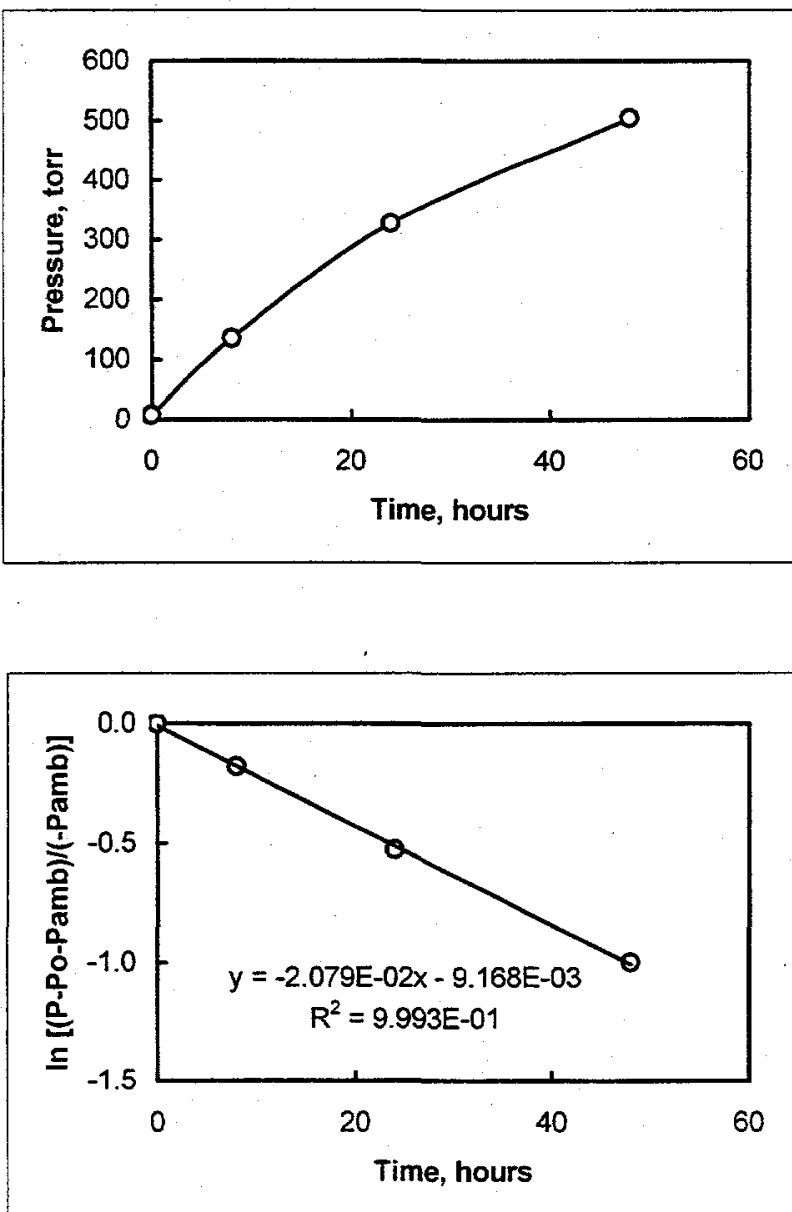
Film:

Panel:

Gas:

Internal Volume:
Vecat

V-IV-2

Helium

$7.51 \mathrm{~cm}^{3}$

$\begin{array}{rrrr}\text { Date } & \text { Time } & \text { Hours } & P, \text { torr } \\ 3 / 29 / 99 & 9: 45 \text { AM } & 0 & 4.2 \\ 3 / 30 / 99 & 10: 20 \mathrm{AM} & 24 & 146.3 \\ 3 / 31 / 99 & 10: 45 \mathrm{AM} & 48 & 262.3 \\ 4 / 1 / 99 & 11: 05 \mathrm{AM} & 72 & 361.6 \\ 4 / 5 / 99 & 9: 45 \mathrm{AM} & 166.4 & 594.6\end{array}$
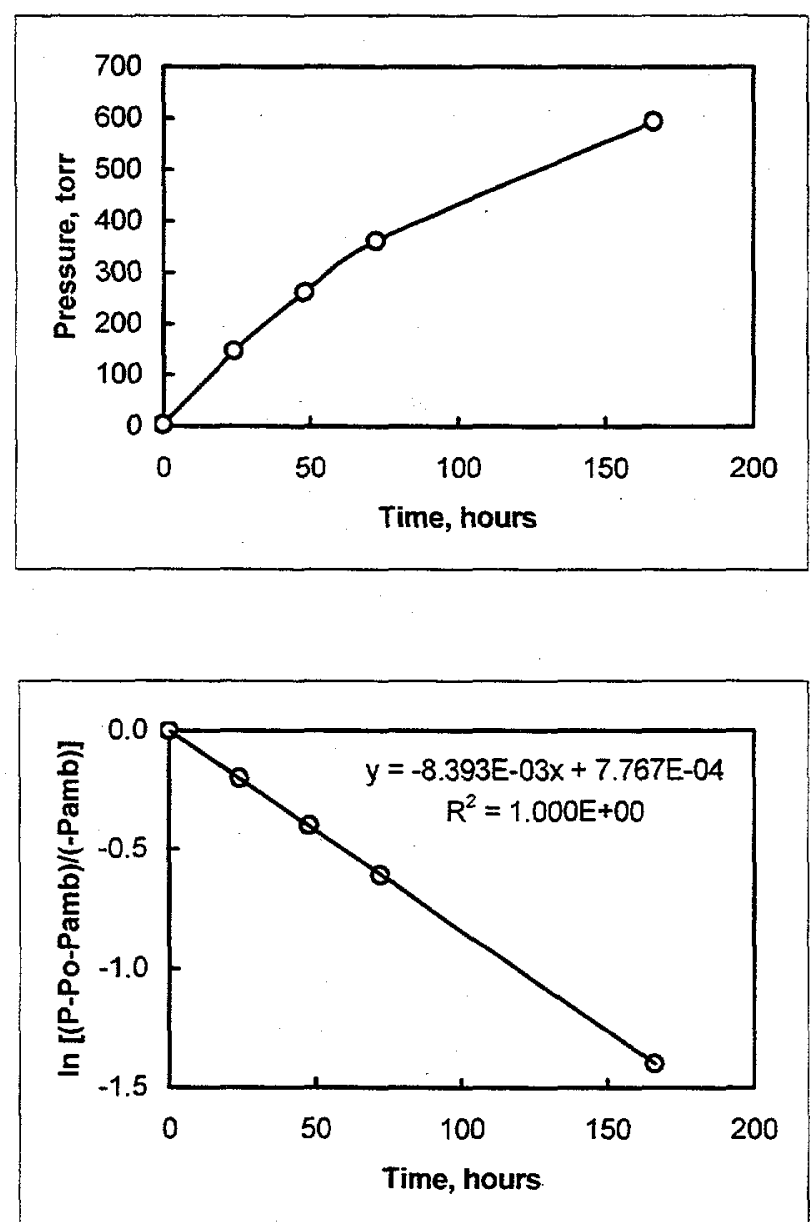
$\begin{array}{ll}\text { Film: } & \text { Vecat } 4 \text { inch wide heat seal } \\ \text { Panel: } & \text { V-IV-3 } \\ \text { Gas: } & \text { Helium } \\ \text { Internal Volume: } & 15.20 \mathrm{~cm}^{3}\end{array}$

$\begin{array}{rrrr}\text { Date } & \text { Time } & \text { Hours } & P, \text { torr } \\ 3 / 30 / 99 & 10: 20 \mathrm{AM} & 0 & 4.2 \\ 3 / 31 / 99 & 10: 45 \mathrm{AM} & 24 & 98.0 \\ 4 / 1 / 99 & 11: 05 \mathrm{AM} & 48 & 186.2 \\ 4 / 5 / 99 & 9: 45 \mathrm{AM} & 142.4 & 429.1 \\ 4 / 7 / 99 & 10: 00 \mathrm{AM} & 190.2 & 514.9\end{array}$
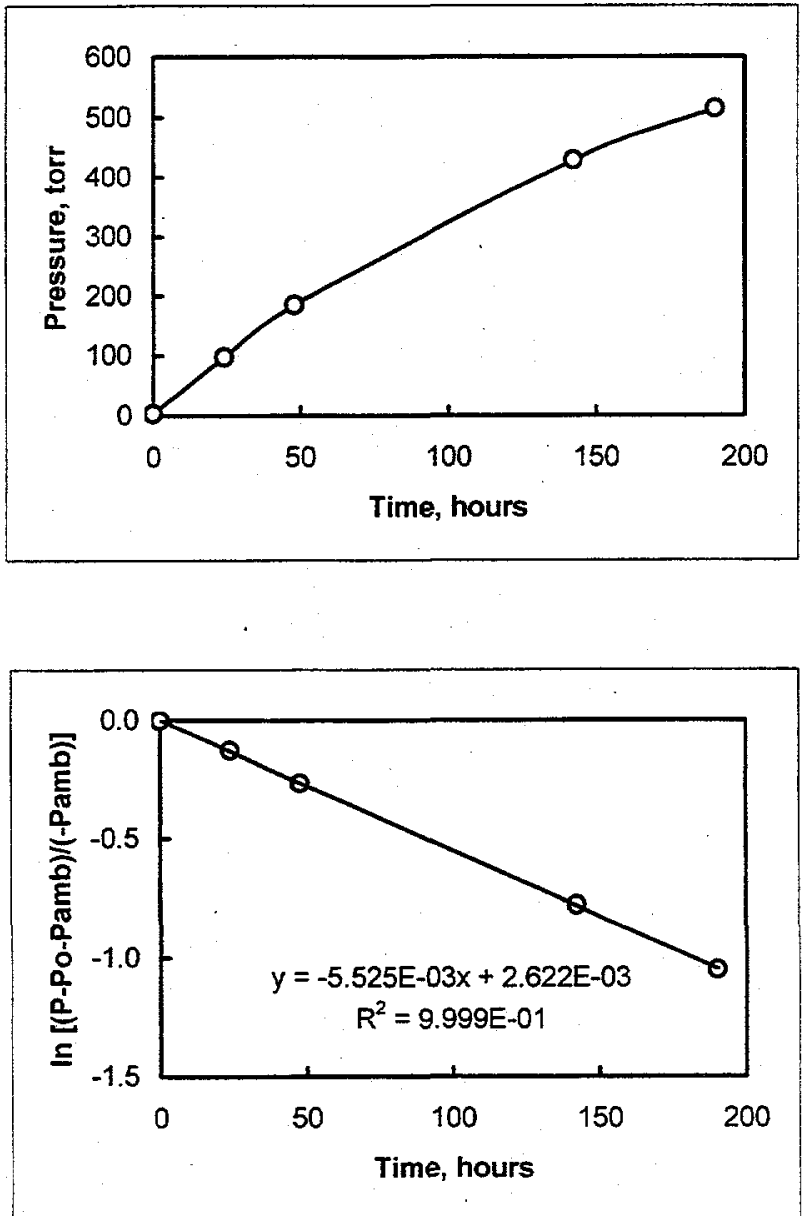
Film:

Panel Set:

Vecat 4 inch wide heat seal

Gas:

V-IV

Helium

$P=P o+P a m b[1-\exp (-b t)]$

\begin{tabular}{lrrrrr} 
Panel & V, cc & \multicolumn{1}{c}{$A_{1}$ in. ${ }^{2}$} & b & \multicolumn{2}{c}{ A b Permeance } \\
V-IV-1 & 0.00 & 198.4 & $2.079 E-02$ & $9.543 E+03$ & 1.28 \\
V-IV-2 & 7.51 & 199.0 & $8.393 E-03$ & $2.371 E+04$ & 1.20 \\
V-IV-3 & 15.20 & 199.0 & $5.525 E-03$ & $3.602 E+04$ & 1.25
\end{tabular}

Permeance units $=c c(S T P) / 100$ in. $^{2} \cdot$ atm $\cdot$ day

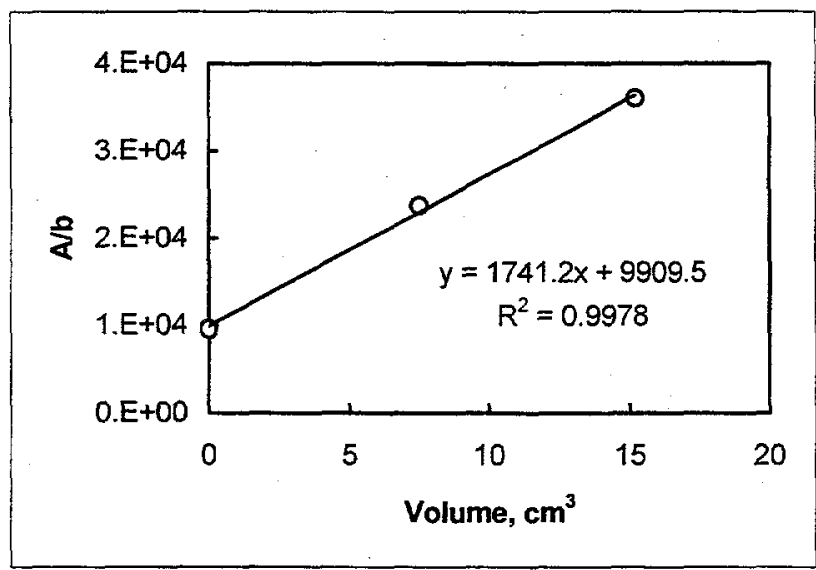

$V_{0}=$

$5.7 \mathrm{~cm}^{3}$ 
Film:

Panel:

Gas:

Internal Volume:
Vecat

V-IV-1

Helium

$0 \mathrm{~cm}^{3}$

$\begin{array}{rrrr}\text { Date } & \text { Time } & \text { Hours } & P \text {, torr } \\ 7 / 27 / 99 & 11: 15 \mathrm{AM} & 0 & 23.9 \\ 7 / 27 / 99 & 5: 15 \mathrm{AM} & 6 & 121.7 \\ 7 / 28 / 99 & 11: 45 \mathrm{AM} & 24 & 357.4 \\ 7 / 29 / 99 & 12: 30 \mathrm{PM} & 48.25 & 541.5\end{array}$
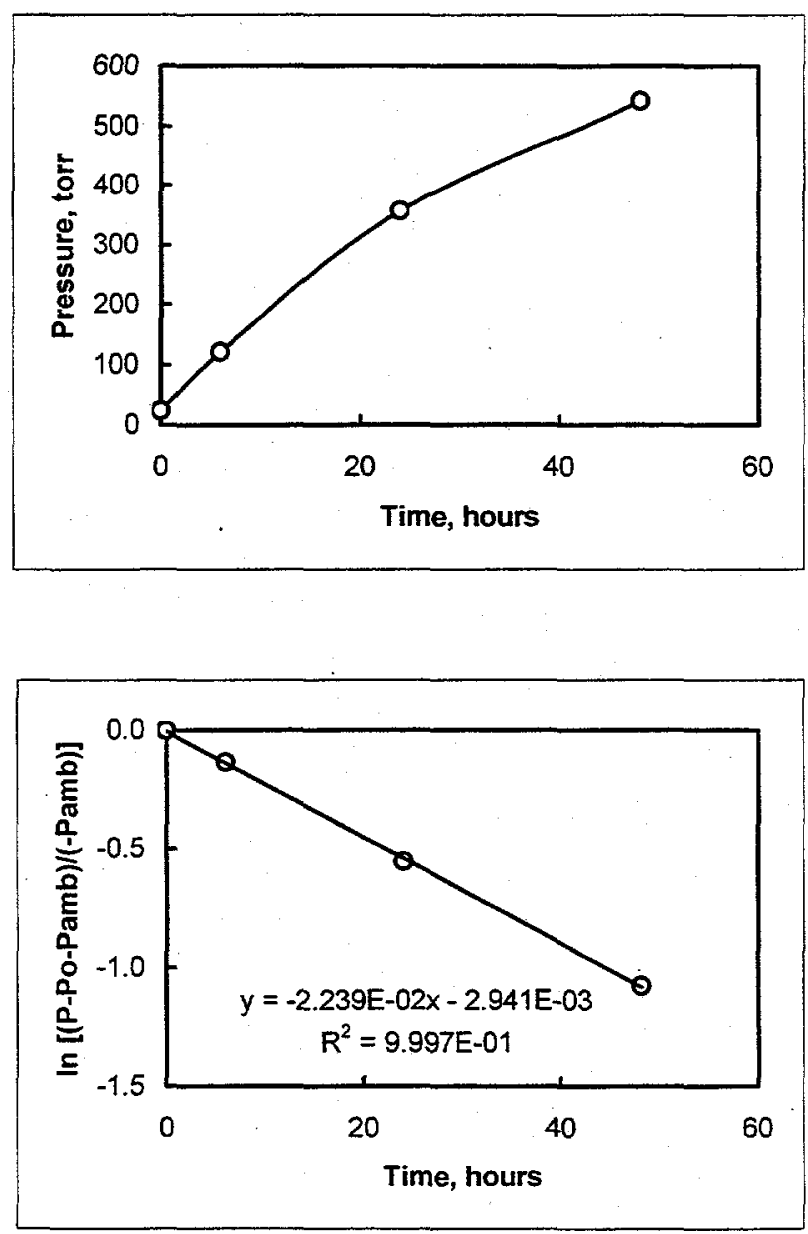
Film:

Panel:

Gas:

Internal Volume:
Vecat

V-IV-2

Helium

$7.51 \mathrm{~cm}^{3}$
0.4 inch wide heat seal

$\begin{array}{rrrr}\text { Date } & \text { Time } & \text { Hours } & P \text {, torr } \\ 7 / 27 / 99 & 11: 15 \mathrm{AM} & 0 & 13.5 \\ 7 / 27 / 99 & 5: 15 \mathrm{AM} & 6 & 47.3 \\ 7 / 28 / 99 & 11: 45 \mathrm{AM} & 24 & 151.4 \\ 7 / 29 / 99 & 12: 30 \mathrm{PM} & 48.25 & 266.1 \\ 7 / 30 / 99 & 1: 00 \mathrm{PM} & 72.25 & 368.1 \\ 8 / 2 / 99 & 1: 30 \mathrm{PM} & 144.25 & 565.3\end{array}$
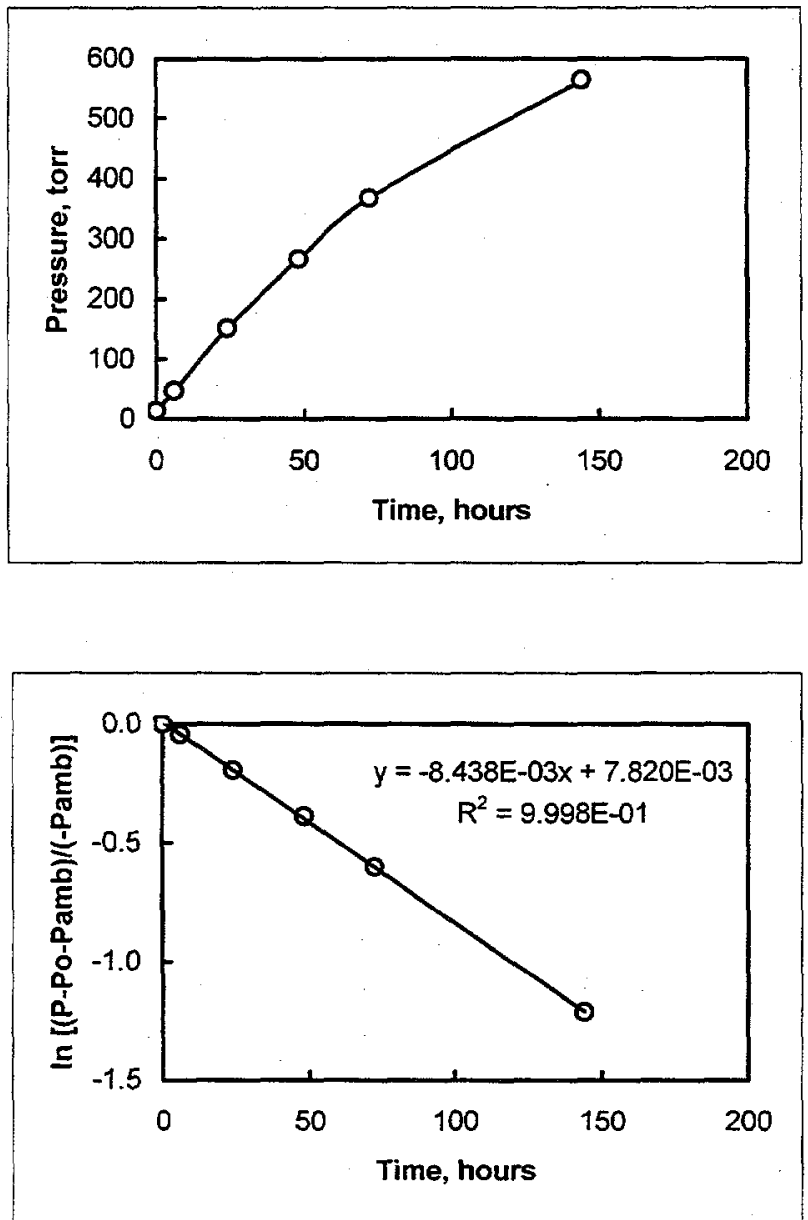
Film:

Panel:

Gas:

Internal Volume: $\quad 15.20 \mathrm{~cm}^{3}$

Vecat

V-IV-3

Helium
0.4 inch wide heat seal

$\begin{array}{rrrr}\text { Date } & \text { Time } & \text { Hours } & \text { P, torr } \\ 7 / 27 / 99 & 11: 15 \text { AM } & 0 & 10.4 \\ 7 / 27 / 99 & 5: 15 \text { AM } & 6 & 32.6 \\ 7 / 28 / 99 & 11: 45 \text { AM } & 24 & 103.0 \\ 7 / 29 / 99 & 12: 30 \mathrm{PM} & 48.25 & 185.0 \\ 7 / 30 / 99 & 1: 00 \mathrm{PM} & 72.25 & 256.4 \\ 8 / 2 / 99 & 1: 30 \mathrm{PM} & 144.25 & 433.1\end{array}$
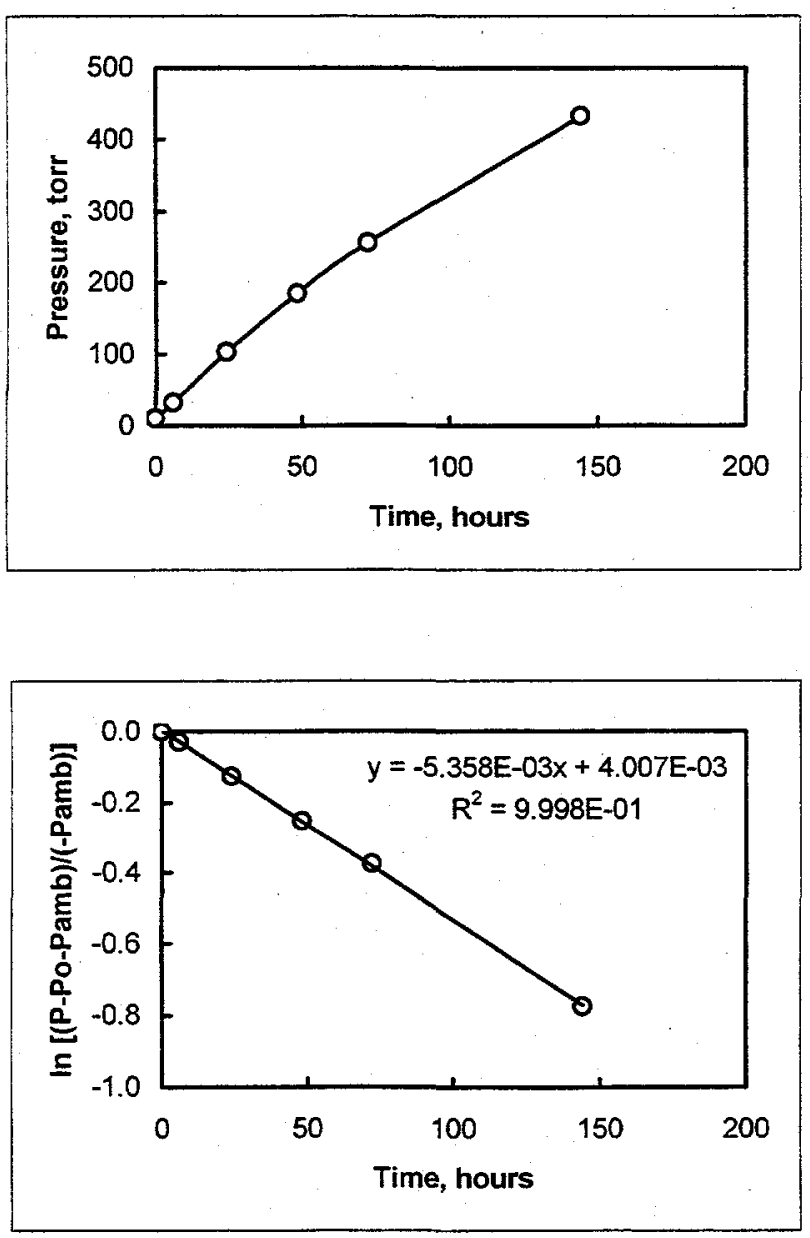
Film: $\quad$ Vecat $\quad 0.4$ inch wide heat seal

Panel Set: V-IV

Gas: Helium

$P=P o+P a m b[1-\exp (-b t)]$

\begin{tabular}{lrrrrr} 
Panel & V, cc & A, in. ${ }^{2}$ & b & \multicolumn{2}{c}{ A/b Permeance } \\
V-IV-1 & 0.00 & 198.4 & $2.239 E-02$ & $8.861 E+03$ & 1.19 \\
V-IV-2 & 7.51 & 199.0 & $8.438 E-03$ & $2.358 E+04$ & 1.13 \\
V-IV-3 & 15.20 & 199.0 & $5.358 E-03$ & $3.714 E+04$ & 1.16
\end{tabular}

Permeance units $=c c(S T P) / 100$ in. ${ }^{2} \cdot a t m \cdot d a y$

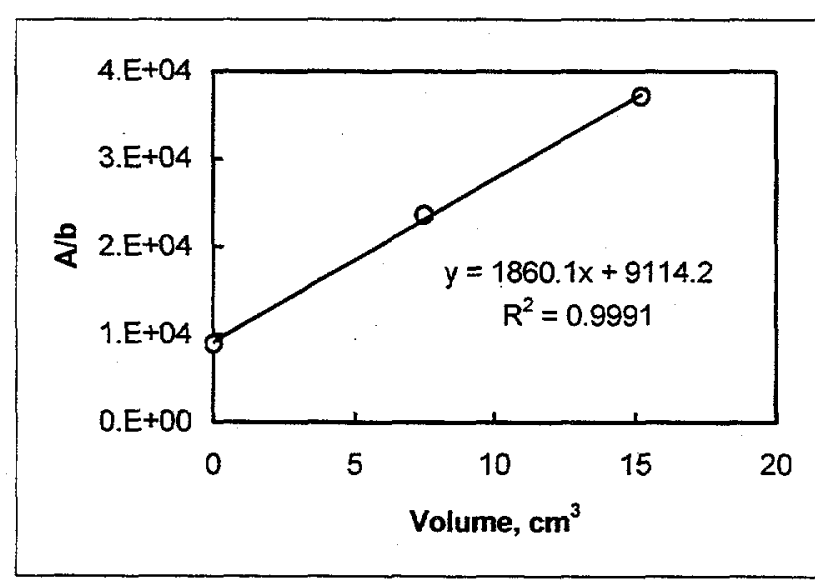
$V_{0}=$
$4.9 \mathrm{~cm}^{3}$ 


\section{INTERNAL DISTRIBUTION}

1-10. Kenneth E. Wilkes, Principal Investigator, Bldg. 4508, MS-6092

11. R. A. Bradley, Bldg. 4500S, MS 6161

12. A. J. Luffman, Bldg. 5002, MS-6416

13. C. A. Valentine, Bldg. 701SCA, MS-8242

14. Laboratory Records - RC, Bldg. 4500-N, MS-6285

15-16. Laboratory Records, Bldg. 4500-N, MS-6285

\section{EXTERNAL DISTRIBUTION}

17. Arun Vohra, Department of Energy, EE-41, 1000 Independence Ave., S. W., Washington DC 20585

18. P. L. Gorman, Department of Energy, Oak Ridge Operations Office, Post Office Box 2008, Oak Ridge, Tennessee 37831-6269

19-28. G. Merton Cumberbatch, E. I. DuPont de Nemours and Company, DuPont Packaging and Industrial Polymers, Chestnut Run Plaza, P. O. Box 80712, Wilmington, Delaware 19880-0712

29-33. Chris Meyer, VacuPanel, Inc., 81 East Main Street, Xenia, Ohio 45385

34-35. DOE, Office of Scientific and Technical Information, Office of Information Service, P.O. Box 62, Oak Ridge, TN 37831 